Final Report

FHWA/IN/JTRP-2004/18

\title{
DEVELOPMENT OF A STRATEGY FOR PREPARING AN INDOT STORM WATER QUALITY MANAGEMENT PLAN
}

\author{
by \\ Lynn A. Corson, Ph.D. \\ Director \\ Indiana Clean Manufacturing Technology and Safe Materials Institute \\ School of Civil Engineering \\ Purdue University \\ Joint Transportation Research Program \\ Indiana SPR 2752 \\ Project No. C-36-68S \\ File No. 4-7-19 \\ Conducted in Cooperation with the \\ Indiana Department of Transportation \\ and the U.S. Department of Transportation \\ Federal Highway Administration
}

The contents of this report reflect the views of the author who is responsible for the facts and accuracy of the data presented herein. The contents do not necessarily reflect the official views or policies of the Indiana Department of Transportation and Federal Highway Administration. This report does not constitute a standard, specification, or regulation.

Purdue University

West Lafayette, Indiana

November 2004 


\section{TECHNICAL Summary}

INDOT Research

Technology Transfer and Project Implementation Information

TRB Subject Code: 23-5 Waste Water and Disposal

Publication No.: FHWA/IN/JTRP-2004/18, SPR-2752

November 2004

Final Report

\section{Development of a Strategy for Preparing an INDOT Storm Water Quality Management Plan}

\section{Introduction}

U.S. EPA regulations (40 CFR parts 9, 122, 123 and 1214) promulgated December 8, 1999 (FR 58721) require small, municipal, separate, storm sewer systems (MS4s) to obtain National Pollutant Discharge Elimination System (NPDES) permits for storm water discharges. State transportation agencies are regulated by the EPA rule as MS4s.

The focus of the research was on providing documentation and data that (1) could be submitted to the Indiana Department of Environmental Management (IDEM) as part of its permit application and (2) would substantiate the decisions of INDOT officials concerning the attributes of its Storm Water Quality Management Plan which, because of the size, statewide authority and complexities of the organization, are substantially different than those of a municipality.

\section{Findings}

The report and its findings are organized by research topic relevant to selected sections of the Storm Water Quality Management Plan defined in the Scope of Work:

\section{Identification of the entities [maintenance facilities and highways] included in the MS4 areas.}

Fifty-nine of INDOT's 142 facility locations (42\%) are located within MS4 areas and approximately 1,812 centerline miles (16\%) of the 11,216 centerline miles maintained by the state are also within MS4 areas. Tables are included that show the number of facility locations and centerline miles by INDOT district and MS4 area.

\section{List of all known receiving waters or, if the discharge is to another MS4, the name of the MS4 and the initial receiving water.}

Receiving waters for direct discharge of storm water from state maintained highways are identified and MS4 operators of combined sanitary and storm sewer and separate storm sewer systems to which INDOT discharges are also identified, along with the receiving waters of the operator's discharge.

\section{Identification of Known Sensitive [Water] Areas}

All state-maintained highway segments -- within and outside MS4 areas -- are identified by "sensitivity level;” i.e., a scoring system based on the four criteria stated in Rule 13 [327IAC15-13$5(70)$ ], and mileage is estimated for each of the four levels in each INDOT district.

\section{Monitoring Data for the MS4 Area Receiving Waters}

Water quality monitoring data from INDOT's monitoring program, in the summer of 2003, at 87 bridges on sensitivity ("priority") level 1 and 2 highways has been tabularized and provided at a publicly-accessible website [www.ecn.purdue.edu/CMTI/stormwater/SWQM P_FSWQM.htm]. USGS Real-time Flow Gauge and Fixed Surface Water Quality Monitoring Station data for these and all other state waters are also available at this website.

\section{Assessment of Selected Structural and Non-Structural Best Management Practices (BMPs) Currently Implemented by INDOT}

Various highway structural and non-structural maintenance BMPs are identified and discussed, 
including those pertaining to: application of deicers, prototype salt storage buildings, brinemaking, use of alternative anti-caking agents in road salts, Operating Procedures and other documents governing deicing operations, drainage systems, street sweeping, bridge cleaning, bridge painting, construction and maintenance in karst areas and in the region of the state having a solesource aquifer, and constructed wetlands.

\section{Implementation}

Recommendations for implementation within each of the five research topic areas are:

\section{Identification of the entities [maintenance facilities and highways] included in the MS4 areas.}

Greenfield (14) and LaPorte (12) have the greatest number of maintenance facility locations within MS4 areas. Greenfield (469) and LaPorte (452) are the two districts with the greatest number of centerline miles in MS4 area and, also, the greatest number of "sensitive" miles, 246 and 317, respectively.

LaPorte District, with 84 percent of the Level 1 sensitive highway segments and 85 percent of the Level 2 sensitive highway segments, should receive priority attention. Within LaPorte District, priority should be given to municipal MS4s with the greatest "sensitive" highway segment mileage: Porter (24.8), Portage (22.9) and Michigan City (10.8), for Level 1, and Merrillville (12.1), Hobart (8.2) and Lake Station (8.1), for Level 2. Priority attention by INDOT to sensitive highway segments in these six MS4s will address 86.9 (66\%) of the 131.4 miles of the combined Level 1 and 2 sensitive highway segments in the state.

\section{List of all known receiving waters or, if the discharge is to another MS4, the name of the MS4 and the initial receiving water. \\ INDOT facilities in MS4 Areas to which priority attention should be directed in each District, because of their proximity to sensitive areas, include:}

\section{Crawfordsville \\ Lafayette Unit: not connected to POTW; 1 mile of recreation waters; 3,000' of vulnerable groundwater; 3,000' of an ETR natural area; \\ Fort Wayne \\ Fort Wayne District, Sub and Unit: 3,000' of community public well; 1 mile of recreation waters; 3,000' of vulnerable groundwater; 3,000' of an ETR natural area;}

U.S. 27 South Unit: not connected to POTW; 3,000' of community public well; 3,000' of vulnerable groundwater;

Greenfield

Indianapolis Sub and 2 Units: not connected to a POTW; 3,000' of a community public well [replacement facilities being constructed in 2004]

Indianapolis Unit $3\left(71^{\text {st }}\right.$ St): not connected to POTW; 3,000' of vulnerable groundwater;

LaPorte

Mishawaka Unit: not connected to POTW; 3,000' of community public well; 1 mile of recreation waters;

Chesterton Unit: not connected to POTW; 3,000' of community public well; 1 mile of high quality and exceptional use waters;

Seymour

Madison Sub: not connected to POTW; 1 mile of recreation water;

\section{Vincennes}

Bedford Unit: located in karst area; 3,000' of vulnerable groundwater; 3,000' of an ETR natural area;

$\underline{\text { Toll Road }}$

Toll Road District: not connected to POTW; 3,000' of community public well; 3,000 ' of vulnerable groundwater; 3,000' of an ETR natural area;

Elkhart Maintenance: not connected to POTW; 3,000' of community public well; 3,000' of vulnerable groundwater; 3,000' of an ETR natural area;

Porter Maintenance: not connected to POTW; 3,000' of vulnerable groundwater; 3,000' of an ETR natural area.

\section{Identification of Known Sensitive [Water] Areas}

INDOT, as an MS4 operator, is expected to implement control measures "to ensure that existing...state...operations are performed in ways that will reduce contamination of storm water discharges" [327IAC15-13-17(b)]. 
INDOT needs to assure the implementation of, at least, the following control measures as BMPs in sensitive areas:

- Covering, or otherwise reducing, the potential for polluted storm water run-off from deicing salt or sand storage piles.

- $\quad$ BMPs for vehicular maintenance areas.

- Prohibition of equipment or vehicle wash waters and concrete or asphalt hydrodemolition wastewaters into storm water run-off, except under the allowance of an appropriate NPDES wastewater permit.

- Minimization of pesticide and fertilizer use. Pesticides shall be used, applied, handled, stored, mixed, loaded, transported, and disposed of via Office of the Indiana State chemist's guidance requirements.

IV. Monitoring Data for the MS4 Area Receiving Waters

INDOT should schedule its water quality monitoring of sensitivity ("Priority") level 1 and 2 highway segments for spring, following the snow/ice operations season, and fall, before the season. Real time USGS flow gauge and fixed surface water quality monitoring data need to be integrated with INDOT's monitoring data to characterize the water quality of receiving streams, thereby avoiding IDEM requirements to sample and conduct laboratory tests to determine water quality.

\section{Assessment of Selected Structural and Non-Structural Best Management Practices (BMPs) Currently Implemented by INDOT}

INDOT should revise existing policies, purchasing agreements, contracts and Operating Procedures and/or create new ones to promote the adoption and practice of best management practices to -

- continue to connect maintenance facilities to municipal POTWs for the discharge of vehicle washwater;

- $\quad$ increase the number of facilities making and applying brine;

- $\quad$ expand the prototype salt storage building currently at Tipton Unit to other facility locations; identify vendors who offer lesstoxic alternatives to ferric ferrocyanide as an anti-caking agent;

- modify Operating Procedure No. 22: Snow and Ice Chemicals - Pollution Control Guidelines (August 24, 1998) so it conforms to current practices and state and federal environmental regulations;

- instruct District directors to establish a schedule for cleaning minor draining structures (inlets and catch basins), pursuant to INDOT Performance Standard Code 2350, and submit the schedules to the Environmental Services Division for inclusion in the storm water permit application;

- communicate to MS4 municipalities that they may "count" the volume or weight of trash from street sweeping in their storm water permit reports to IDEM;

- adopt a procedure requiring the collection or, minimally, the filtering of bridge washwater before discharging to waters of the state;

- $\quad$ amend Standard Specification 619 - Painting Bridge Steel with an INDOT policy requiring that Section 619.06(a) Pollution Control be applied to Section 619.08, Surface Preparation and Section 619.09, Paint Systems, to protect waters under and adjacent to bridges from pollution that may result from surface cleaning or paint application;

- embody the provisions of the October 13, 1993 Karst Agreement, signed by INDOT, IDEM, IDNR and USF\&WS in a policy and operating procedure to govern construction and maintenance of state highways in karst terrain;

- prepare operating procedures for the periodic inspection and maintenance of BMPs constructed in karst terrain, namely, peat filters and two chamber detention ponds;

- determine whether highway construction and maintenance operations performed since the 1988 signing of the Sole Source Aquifer Memorandum of Understanding are in conformance with the MOU and, if not, prepare appropriate policies and operating procedures;

- determine the efficiency of the constructed wetlands at the Toll Road Grant Street exit (14A) as a determinant of whether this type of BMP should be replicated elsewhere. 


\section{Contacts}

For more information:

Dr. Lynn A. Corson

Principal Investigator

Indiana Clean Manufacturing Technology

and Safe Materials Institute

Purdue University

West Lafayette IN 47907

Phone: (765) 463-4749

Fax: (765) 463-3795

E-mail: corsonl@ecn.purdue.edu
Indiana Department of Transportation

Division of Research

1205 Montgomery Street

P.O. Box 2279

West Lafayette, IN 47906

Phone: (765) 463-1521

Fax: (765) 497-1665

\section{Purdue University}

Joint Transportation Research Program

School of Civil Engineering

West Lafayette, IN 47907

Phone: (765) 494-9310

Fax: (765) 496-7996

jtrp@ecn.purdue.edu

http://www.purdue.edu/jtrp 


\section{TABLE OF CONTENTS}

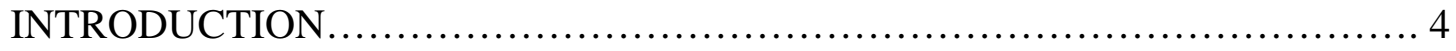

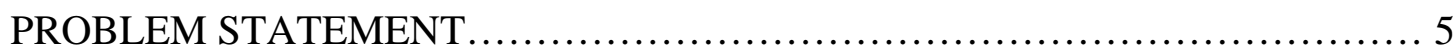

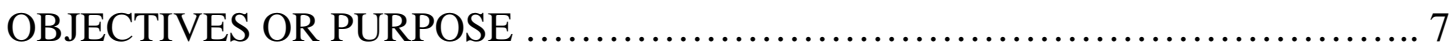

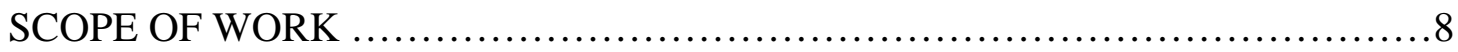

ANALYSIS OF THE DATA, CONCLUSIONS AND

RECOMMENDATIONS, INCLUDING STRATEGIES

FOR IMPLEMENTATION ................................................. 13

APPENDICES....................................................... 76 


\section{LIST OF TABLES}

Table 1 INDOT Maintenance Facilities Within and Outside

MS4 Areas....................................................14

Table 2 MS4 Miles by District and Sensitivity Level..........................15

Table 3 Level 1 “Sensitive” Highway Segments in MS4s....................17

Table 4 Level 2 "Sensitive” Highway Segments in MS4s.....................21

Table 5 Facilities in MS4 Areas Characterized by Selected

Environmental Sensitivity Criteria..................................26 


\section{INTRODUCTION}

U.S. EPA regulations (40 CFR Parts 9, 122, 123, and 1214) promulgated December 8, 1999 (FR 58721) require small, municipal, separate, storm sewer systems (MS4s) to obtain National Pollutant Discharge Elimination System (NPDES) permits for storm water discharges. State transportation agencies are regulated by the EPA rule as MS4s.

Indiana's authority for issuing storm water permits to MS4s is found at 327 IAC 52-9.

The original timeframe for this project -- January 9, 2002 to March 31, 2004 -- was extended to accommodate the eight month delay encountered in adopting the Indiana Storm Water rule. Also, the scope of the project was expanded November 25, 2002 by the JTRP Board to include water quality monitoring.

Midway through the rule adoption process, the Indiana Department of Environmental Management (IDEM) decided that it would issue INDOT's NPDES pursuant to the general storm water discharge permit rule, 327 IAC 5-4-6, rather than the specific MS4 “Rule 13,” 327 IAC 15-13-1, but it noted a provision of the former rule [327 IAC 5-4-6(d)(1)(A)] that allows the department to consider which of the requirements of "Rule 13" should be contained in the permit issued under "5-4-6."

This change rendered the timetable included in the study's proposal (page 2) and the scheduled dates for completion of responses to the three "Parts" of the permit (pages 4 and 5) invalid. Furthermore, a decision by the department to await the conclusion of negotiations with the City of Indianapolis concerning its storm water permit, before beginning negotiations with INDOT about its permit, introduced uncertainty as to what the actual permit requirements would be: INDOT's permit application [Appendix A], 
submitted to IDEM September 24, 2003, was not discussed until May 18, 2004, two weeks before the submittal of the draft of this final report.

The "Purpose of the Proposal," described in the study's proposal, was to "develop a strategy for preparing the SWQMP (Storm Water Quality Management Plan) [and] subsequently, the Plan, itself.” However, because of the above-described delay and change, the focus of the research was on providing documentation and data that (1) could be submitted to IDEM as part of its permit application and (2) would substantiate the decisions of INDOT officials concerning the attributes of its Storm Water Quality Management Plan which, because of the size, statewide authority and complexities of the organization, are substantially different than those of a municipality.

\section{PROBLEM STATEMENT}

State transportation facilities -- highways, rest areas and maintenance facilities -are or contain impermeable surfaces that collect precipitation and can become a non-point source of storm water or meltwater runoff to surface waters known as "waters of the state.”

Allowing or directing runoff of storm water to surface water has been considered by federal and state regulation to be a "discharge," since the first storm water rules were promulgated in 1990, and subject to permit authority. Selected industrial facilities and large cities (such as Indianapolis) were required by the 1990 regulation to obtain permits or seek exemptions from permit authority. State transportation agencies were not included in this first "phase" (Phase I), but are specifically mentioned in the Phase II regulation. 
The Indiana Department of Transportation, like other states' transportation agencies, has not previously implemented department-wide policies and procedures to prevent storm water migration from its property to surface water. The practice of state transportation agencies, in fact, is to intentionally clear the highways of accumulated precipitation as quickly as possible to ensure the safety of motorists. This concern for safety has prompted considerable innovation in highway design and construction to facilitate the collection of storm water and its discharge via a drainage system to the nearest ditch, creek, river or stream as efficiently as possible. It follows, then, that the design practices relevant to highways would be applied to rest areas along these highways and to the facilities where the highway maintenance "crews" are located.

Water quality is the focus of the federal Water Pollution Control Act of 1972, as amended, and the attendant U.S. Environmental Protection Agency and state regulations. The "quality" of storm water that contains chloride from road salt and petroleum and heavy metal constituents from automobiles and silt from runoff of neighboring properties into the highway drainage system is a chief concern. Also, the variety of activities performed at highway maintenance facilities, many of which require the use of chemical products and/or generate chemical pollutants, makes these potential sources of water quality problems among transportation facilities.

Previous research conducted by this study's Principal investigator have welldocumented details of the "problem" and need not be elaborated here. These studies include: 
- "Development of a Strategy for Compliance with EPA and OSHA Regulations Applicable to INDOT Facilities," Joint Highway Research Project, FHWA/IN/JHRP-92-22, June 15, 1994;

- "Follow-up Study to FHWA/IN/JHRP-92/22: Development of a Strategy for Compliance with EPA and OSHA Regulations Applicable to INDOT Facilities,” Joint Highway Research Project, FHWA/IN/JTRP-2000/29, April 2001,

- "Development of a Database and System for Analyzing the Actual and Potential Impacts on the Environment of Existing and Planned INDOT Sites,” Joint Highway Research Project, FHWA/IN/JTRP-2002/24, February 2003.

\section{OBJECTIVES OR PURPOSE}

The purpose of the study was to conduct research and prepare documents, data tables, reports and GIS maps to be included in the INDOT SWQMP that address each of the following Minimum Control Measures (MCMs) specified in the federal and state regulation:

1. public education and outreach

2. public participation and involvement

3. illicit discharge detection with elimination

4. construction site runoff control

5. post-construction runoff control

6. pollution prevention and good housekeeping

The MCMs are minimum measures which, when implemented by INDOT, will ensure that storm water quality meets the minimum water quality standards. 


\section{SCOPE OF WORK}

The Phase II “Rule 13” format for an NPDES storm water permit application is set forth below. This was assumed to be the general format that will be required by IDEM and, therefore, constituted the scope of work for this research. The Plan is comprised of three major components:

- Part A - Initial Application

- $\quad$ Listing of the MS4 entities [facilities and highways] within MS4 areas.

- List of all known receiving waters or, if the discharge is to another MS4, the name of the MS4 entity and the initial receiving water; receiving waters include, at a minimum, waters listed on the United States Geological Survey National Hydrography Dataset.

- Part B - Baseline Characterization

- The identification of known sensitive areas, such as public swimming areas, surface drinking water intakes, waters containing threatened or endangered species and their habitat, or state outstanding resource and exceptional use waters. The identified sensitive areas should be given the highest priority for the selection of BMPs and the prohibition of new or significantly increased MS4 discharges.

- A review of known existing and available monitoring data of the MS4 area receiving waters.

- The identification of areas having a reasonable potential for or actually causing storm water quality problems based on the available and relevant chemical, biological, physical, land use, and complaint data. 
- An investigation of land usage and assessment of structural and nonstructural storm water BMP locations and conclusions, such as key observation or monitoring locations in the MS4 conveyances, derived from the land usage investigation.

- Assessment results of BMP locations and, as appropriate, the structural condition of the BMP related to the BMP's effectiveness in improving storm water quality. As appropriate, this assessment should include recommendations for placement and implementation of additional BMPs within the MS4 area.

- Part C - Program Implementation

- An initial evaluation of the storm water program for the MS4 area. This evaluation should include information on all known structural and nonstructural storm water BMPs utilized.

- A detailed program description for each minimum control measure (MCM);

- A timetable for program implementation milestones, which includes milestones for each of the MCMs and applicable Part B: Baseline Characterization conclusions (BMP recommendations, additional protective measures for sensitive areas, and correcting identified water quality problems).

- As appropriate, a schedule for ongoing characterization of the receiving waters either at, or in proximity to, outfall locations identified in Part B: 
Baseline Characterization to evaluate BMP effectiveness and receiving water quality.

- A narrative and mapped description of the MS4 area boundaries that indicate responsible MS4 entity areas for each MCM.

- An estimate of the linear feet of MS4 conveyances within the MS4 area, segregated by MS4 type, for example, by open ditch or pipe.

- A summary of which structural BMP types will be allowed in new development and redevelopment for the MS4 area.

- A summary on [of] storm water structural BMP selection criteria, and, where appropriate, associated performance standards that must be met after installation to indicate BMP effectiveness.

- The identification of programmatic indicators, grouped by corresponding MCM:

+ Number and location of storm drains marked or cast, segregated by marking method.

+ Estimated or actual linear feet or percentage of MS4 conveyances mapped and indicated on an MS4 area map.

+ Number and location of MS4 area outfalls mapped.

+ Number and location of MS4 area outfalls screened for illicit discharges.

+ Number and location of illicit discharges detected.

+ Number and location of illicit discharges eliminated. 
+ Number of and estimated or actual amount of material, segregated by type, collected from HHW [roadside trash] collections in the MS4 area.

+ Number and location of constituent drop-off centers [maintenance facilities] for [INDOT] automotive fluid recycling.

+ Number of construction sites obtaining an MS4 entity-issued storm water run-off permit in the MS4 area.

+ Number of construction sites inspected.

+ Number and type of enforcement actions taken against construction site operators.

+ Number, type, and location of structural BMPs installed.

+ Number, type, and location of structural BMPs maintained or improved to function properly.

+ Type and location of nonstructural BMPs utilized.

+ Number and location of new ... institutional refueling areas, ... that replaced existing tank systems that have installed storm water BMPs.

+ Number and location of MS4 entity facilities that have containment for accidental releases of stored polluting materials.

+ Estimated or actual acreage or square footage, amount, and location where pesticides and fertilizers are applied by a regulated MS4 entity to places where storm water can be exposed within the MS4 area. 
+ Estimated or actual linear feet or percentage and location of unvegetated swales and ditches that have an appropriately-sized vegetated filter strip.

+ Estimated or actual linear feet or percentage and location of MS4 conveyances cleaned or repaired.

+ Estimated or actual linear feet or percentage and location of roadside shoulders and ditches stabilized, if applicable.

+ Number and location of storm water outfall areas remediated from scouring conditions, if applicable.

+ Number and location of deicing salt and sand storage areas covered or otherwise improved to minimize storm water exposure.

+ Estimated or actual amount, in tons, of salt and sand used for snow and ice control.

+ Estimated or actual amount of material by weight collected from catch basin, trash rack, or other structural BMP cleaning.

+ Estimated or actual amount of material by weight collected from street sweeping, if utilized.

+ If applicable, number or percentage and location of canine parks sited at least one hundred fifty (150) feet away from a surface waterbody. 


\section{ANALYSIS OF THE DATA CONCLUSIONS AND RECOMMENDATIONS, INCLUDING STRATEGIES FOR IMPLEMENTATION}

This section of the report is organized by research topic relevant to selected sections required of the Storm Water Quality Management Plan stated in the Scope of Work.

\section{Identification of the entities [maintenance facilities and highways] included} in the MS4 areas.

The MS4 areas designated by the Indiana Department of Environmental Management (IDEM) can be found at http://www.in.gov/idem/water/npdes/permits/wetwthr/storm/rule13criteria.html, and are included here as Appendix B. The researchers created a GIS layer incorporating the boundaries of these areas and overlaid other layers of data representing geographic locations of maintenance facilities and segments of state-maintained highways. The latitude/longitude coordinates were provided by INDOT based on the use of a commercially available (\$50) Street Atlas software program. Though attempts were made by INDOT staff to ensure accuracy of the coordinates, using aerial and ground photos, errors persist. INDOT should no longer rely on street address identification of their facilities. GPS readings should be recorded for all facilities and appurtenances. [See Appendix C for the corrected file of facility coordinates].

A. Maintenance Facilities

There are approximately 160 INDOT maintenance facilities operated at 142 geographic locations throughout the state. Fifty-nine (59) of these facility locations are located within MS4 areas (42\%) and 83 (58\%) are located outside of MS4 areas. The totals for each INDOT District are enumerated on Table 1. 
Table 1

$\underline{\text { District }}$

Crawfordsville

Fort Wayne

Greenfield

LaPorte

Seymour

Vincennes

Toll Road

Total

\begin{tabular}{ccr}
\multicolumn{3}{c}{ Number of Facility Locations } \\
\cline { 1 - 2 } Within MS4s & $\underline{\text { Outside MS4s }}$ \\
\cline { 2 - 3 } 8 & 10 & 18 \\
8 & 14 & 22 \\
14 & 12 & 26 \\
12 & 12 & 24 \\
7 & 16 & 23 \\
6 & 16 & 22 \\
4 & 3 & 7 \\
59 & & 142
\end{tabular}

The list of facilities, by District, within and outside MS4 areas is included here as Appendix D.

B. Highways

There are 11,216 centerline miles (28,500 lane miles) of state, U.S. and Interstate highways in Indiana. There are 1,812 centerline miles of highway within MS4 areas maintained by INDOT and an additional 100 or so miles of state highways that, over the years, have reverted to local control and, for the purposes of the storm water permit, are within the "operator” jurisdiction of the municipal MS4. Table 2 on the next page reveals the total MS4 mileage by district and by the "Sensitivity Levels” defined and applied by the researchers. The individual highway segments are identified in the CDROM included as Appendix E. 
Table 2

MS4 Miles by District and Sensitivity Level

\begin{tabular}{|c|c|c|c|c|c|c|c|c|c|c|c|c|}
\hline \multicolumn{13}{|c|}{ Sensitivity Level } \\
\hline$\underline{\text { District }}$ & $\underline{1}$ & 2 & 3 & 4 & $1 \mathrm{~K}$ & $2 \mathrm{~K}$ & $3 \mathrm{~K}$ & $4 \mathrm{~K}$ & K only & $\underline{\text { Subtotal }}$ & None & $\underline{\text { Total }}$ \\
\hline Ft. Wayne & 2.5 & 0.1 & & 138.8 & & & & & & 141.4 & 97.4 & 238.8 \\
\hline Greenfield & 1.7 & & 55.1 & 189.0 & & & & & & 245.8 & 223.5 & 469.3 \\
\hline LaPorte & 74.1 & 36.9 & & 205.6 & & & & & & 316.6 & 135.5 & 452.1 \\
\hline Seymour & & & 30.8 & 88.3 & & & & 42.6 & 35.5 & 197.2 & 64.4 & 261.6 \\
\hline Vincennes & & 5.9 & & 54.1 & & & 2.8 & 9.1 & 3.2 & 75.1 & 39.9 & 115.0 \\
\hline Crawfordsville & 8.3 & & & 103.2 & & & & 0.6 & 5.0 & 117.1 & 93.7 & 210.8 \\
\hline Toll Road & 1.5 & 0.4 & & 34.5 & & & & & & 36.4 & 28.5 & 64.9 \\
\hline Total & 88.1 & 43.3 & 85.9 & 813.5 & 0.0 & 0.0 & 2.8 & 52.3 & 43.7 & $1,129.6$ & 682.9 & $1,812.5$ \\
\hline
\end{tabular}

Note: Sensitivity levels 1 through 4 are combined with Karst $(K)$ geology in levels $1 \mathrm{~K}$ through $4 \mathrm{~K}$; "K only" is for sensitivity based only on that feature. Miles to which sensitivity criteria did not apply are designated "None." State maintained highways that have reverted to local control are excluded from the above totals, as are those in "Conditionally Exempt Areas Based on Low Population” and areas adjoining Urbanized Areas, but declared “exempt” by IDEM.

Source: Appendix E: State_Roads_Rule13_listing_2004.els (June 6, 2004) 
INDOT officials decided in 2003 to focus activity on Sensitivity Level 1 and 2 highway segments in each of the districts for the first five-year term of its permit. Those highway segments are identified in Tables 3 and 4 on the following pages for MS4 operators within each district. ${ }^{1}$ This table also identifies the receiving waters for each MS4 operator's combined sewer system, which will be discussed in Section II of this report. $^{2}$

\footnotetext{
${ }^{1}$ from Appendix E of this report

${ }^{2}$ from http://www.in.gov/water/compbr/inspections/index.html
} 


\section{Table 3}

Level 1 “Sensitive” Highway Segments in MS4s

\begin{tabular}{|c|c|c|c|c|c|c|}
\hline$\underline{\text { District }}$ & $\underline{\text { MS4 }}$ & MS4 Operator $^{1}$ & Hwy & $\underline{\text { Alt Name }}$ & $\begin{array}{l}\text { MS4 } \\
\text { Mileage }\end{array}$ & $\underline{\text { Receiving Waters }}^{2}$ \\
\hline \multirow[t]{11}{*}{ Crawfordsville } & Crawfordsville & Crawfordsville & $\mathrm{I}-74$ & & 0.242 & \multirow{8}{*}{$\begin{array}{l}\text { Sugar Creek to Wabash River } \\
\qquad " \\
\text { " } \\
\text { " } \\
\text { " }\end{array}$} \\
\hline & Crawfordsville & " & I-74 Ramp & & 0.393 & \\
\hline & Crawfordsville & $"$ & SR 32 & SR 47 & 0.437 & \\
\hline & Crawfordsville & $"$ & US 136 & SR 32 & 2.467 & \\
\hline & Crawfordsville & $"$ & US 231 & SR 32 & 2.157 & \\
\hline & Crawfordsville & $"$ & US 231 & SR 43 & 0.583 & \\
\hline & \multirow[t]{2}{*}{ Crawfordsville } & \multirow[t]{2}{*}{$"$} & \multirow[t]{2}{*}{ US 231} & \multirow[t]{2}{*}{ US $231 \mathrm{~N}$} & 0.523 & \\
\hline & & & & & 6.802 & \\
\hline & Dayton & \multirow{3}{*}{$\begin{array}{l}\text { Tippecanoe Co. } \\
\text { " }\end{array}$} & \multirow{3}{*}{$\begin{array}{l}\text { I-65 Ramp } \\
\text { SR } 38\end{array}$} & \multirow{3}{*}{ SR $38 \mathrm{E}$} & 0.242 & \\
\hline & Dayton & & & & 1.016 & \\
\hline & & & & & 1.258 & \\
\hline \multirow[t]{2}{*}{ Fort Wayne } & \multirow[t]{2}{*}{ Leo-Cedarville } & \multirow[t]{2}{*}{ Allen Co. } & \multirow[t]{2}{*}{ SR 1} & \multirow[t]{2}{*}{ Leo Rd } & 1.815 & \\
\hline & & & & & 1.815 & \\
\hline \multirow[t]{2}{*}{ Greenfield } & \multirow[t]{2}{*}{ Kokomo } & \multirow[t]{2}{*}{ Kokomo } & \multirow[t]{2}{*}{ SR 22} & \multirow[t]{2}{*}{$7^{\text {th }} \mathrm{St}$} & 0.040 & \multirow[t]{2}{*}{ Wildcat Creek to Wabash River } \\
\hline & & & & & 0.040 & \\
\hline \multirow[t]{8}{*}{ LaPorte } & Chesterton & \multirow{3}{*}{$\begin{array}{l}\text { Chesterton } \\
\quad "\end{array}$} & SR 49 & N. S. Hwy 49 & 0.153 & \multirow{3}{*}{$\begin{array}{l}\text { Little Calumet River to Lake Mich. } \\
\text { " }\end{array}$} \\
\hline & \multirow[t]{2}{*}{ Chesterton } & & \multirow[t]{2}{*}{ US 20} & \multirow[t]{2}{*}{ E US Hwy 20} & 0.348 & \\
\hline & & & & & 0.501 & \\
\hline & E. Chicago & E. Chicago & Ramp & & 1.244 & Grand Calumet River to Lake Mich. \\
\hline & E. Chicago & " & SR 912 & & 1.981 & " \\
\hline & E. Chicago & " & US 12 & Dunes Hwy & 0.199 & $"$ \\
\hline & \multirow[t]{2}{*}{ E. Chicago } & \multirow[t]{2}{*}{$"$} & \multirow[t]{2}{*}{ US 12} & \multirow[t]{2}{*}{ US 20} & 0.590 & \multirow[t]{2}{*}{$"$} \\
\hline & & & & & 4.014 & \\
\hline
\end{tabular}


Level 1 “Sensitive” Highway Segments in MS4s continued

\begin{tabular}{|c|c|c|c|c|c|c|}
\hline$\underline{\text { District }}$ & $\underline{\text { MS4 }}$ & $\underline{\text { MS4 Operator }^{1}}$ & Hwy & $\underline{\text { Alt Name }}$ & $\begin{array}{l}\text { MS4 } \\
\text { Mileage } \\
\end{array}$ & $\underline{\text { Receiving Waters }}^{2}$ \\
\hline \multirow[t]{25}{*}{ LaPorte Cont'd } & Gary & Gary & Ramp & \multirow{3}{*}{ Chicago Ave } & 0.876 & \multirow{7}{*}{$\begin{array}{l}\text { Grand Cal R. \& Little Cal R. } \\
\text { " } \\
\text { " } \\
\text { " } \\
\text { " } \\
\text { " }\end{array}$} \\
\hline & Gary & " & SR 312 & & 0.471 & \\
\hline & Gary & " & SR 912 & & 0.611 & \\
\hline & Gary & $"$ & US 12 & Dunes Hwy & 0.149 & \\
\hline & Gary & " & US 12 & E. Dunes Hwy & 1.552 & \\
\hline & \multirow{2}{*}{ Gary } & \multirow[t]{2}{*}{$"$} & \multirow[t]{2}{*}{ US 12} & \multirow[t]{2}{*}{ US 20} & 0.977 & \\
\hline & & & & & 4.636 & \\
\hline & Hammond & Hammond & US 12 & Dunes Hwy & 2.180 & \multirow{3}{*}{$\begin{array}{c}\text { Grand Cal River to Lake Michigan } \\
\text { " }\end{array}$} \\
\hline & \multirow[t]{2}{*}{ Hammond } & \multirow[t]{2}{*}{ Hammond } & \multirow[t]{2}{*}{ US 41} & \multirow[t]{2}{*}{ Calumet Ave } & 0.802 & \\
\hline & & & & & 2.982 & \\
\hline & Michigan City & LaPorte & SR 212 & & 0.252 & \multirow{7}{*}{$\begin{array}{l}\text { Trail Creek to Lake Michigan } \\
\qquad " \\
\text { " } \\
\text { " } \\
\text { " }\end{array}$} \\
\hline & Michigan City & " & US 12 & Dunes Hwy & 4.163 & \\
\hline & Michigan City & $"$ & US 12 & W. US 12 & 0.824 & \\
\hline & Michigan City & $"$ & US 12 & W. Mich. Ave & 3.811 & \\
\hline & Michigan City & $"$ & US 35 & E. Mich. Ave & 0.833 & \\
\hline & \multirow[t]{2}{*}{ Michigan City } & \multirow[t]{2}{*}{$"$} & \multirow[t]{2}{*}{ US 421} & \multirow[t]{2}{*}{ Franklin St } & 0.892 & \\
\hline & & & & & 10.775 & \\
\hline & Ogden Dunes & Ogden Dunes & US 12 & Dunes Hwy & 1.021 & \\
\hline & Ogden Dunes & " & US 12 & E. Dunes Hwy & 0.001 & \\
\hline & Ogden Dunes & $"$ & US 12 & & 0.001 & \\
\hline & \multirow[t]{2}{*}{ Ogden Dunes } & \multirow[t]{2}{*}{$"$} & \multirow[t]{2}{*}{ US 12} & \multirow[t]{2}{*}{ US 20} & 0.001 & \\
\hline & & & & & 1.024 & \\
\hline & Portage & Portage & $\mathrm{I}-94$ & & 2.818 & Burns Ditch to Lake Michigan \\
\hline & Portage & $"$ & I-94 Ramp & & 2.972 & $"$ \\
\hline & Portage & $"$ & SR 249 & & 4.023 & $"$ \\
\hline
\end{tabular}


Level 1 “Sensitive” Highway Segments in MS4s Continued

\begin{tabular}{|c|c|c|c|c|c|c|}
\hline District & MS4 & MS4 Operator ${ }^{1}$ & Hwy & Alt Name & $\begin{array}{l}\text { MS4 } \\
\text { Mileage }\end{array}$ & Receiving Waters $^{2}$ \\
\hline \multirow[t]{22}{*}{ LaPorte Cont'd } & Portage & Portage & US 12 & Dunes Hwy & 5.511 & \multirow{7}{*}{$\begin{array}{c}\text { Burns Ditch to Lake Michigan } \\
\qquad " \\
\qquad " \\
" \\
"\end{array}$} \\
\hline & Portage & " & US 12 & E. Dunes Hwy & 1.573 & \\
\hline & Portage & " & US 12 & & 2.312 & \\
\hline & Portage & " & US 12 & US 20 & 1.573 & \\
\hline & Portage & " & US 12 & W. Mich. Blvd & 0.066 & \\
\hline & \multirow[t]{2}{*}{ Portage } & \multirow[t]{2}{*}{ " } & \multirow[t]{2}{*}{ US 12} & \multirow[t]{2}{*}{ Melton Rd } & 2.067 & \\
\hline & & & & & 22.915 & \\
\hline & Porter & Porter & I-94 & & 4.405 & \multirow{12}{*}{$\begin{array}{l}\text { E. Branch Little Calumet River } \\
\qquad " \\
\text { " } \\
\text { " } \\
" \\
" \\
" \\
" \\
" \\
"\end{array}$} \\
\hline & Porter & " & I-94 Ramp & & 3.505 & \\
\hline & Porter & " & SR 49 & N. SR 49 & 2.083 & \\
\hline & Porter & " & US 12 & Dunes Hwy & 0.643 & \\
\hline & Porter & " & US 12 & E. US 12 & 1.366 & \\
\hline & Porter & " & US 12 & & 4.500 & \\
\hline & Porter & " & US 12 & W. Dunes Hwy & 1.047 & \\
\hline & Porter & " & US 20 & E. US 20 & 0.915 & \\
\hline & Porter & " & US 20 & Melton Rd & 2.402 & \\
\hline & Porter & " & US 20 & & 1.811 & \\
\hline & \multirow[t]{2}{*}{ Porter } & \multirow[t]{2}{*}{$"$} & \multirow[t]{2}{*}{ US 20} & \multirow[t]{2}{*}{ W. US 20} & 2.097 & \\
\hline & & & & & 24.774 & \\
\hline & Whiting & \multirow{3}{*}{$\begin{array}{l}\text { Whiting } \\
\text { " }\end{array}$} & US 12 & \multirow{3}{*}{$\begin{array}{l}\text { Dunes Hwy } \\
\text { US } 20\end{array}$} & 1.050 & \\
\hline & \multirow[t]{2}{*}{ Whiting } & & US 12 & & 0.248 & \\
\hline & & & & & 1.298 & \\
\hline \multirow[t]{3}{*}{ Toll Road } & Hammond & \multirow{3}{*}{$\begin{array}{l}\text { Hammond } \\
\text { " }\end{array}$} & I-90 & & 1.204 & \multirow{3}{*}{$\begin{array}{c}\text { Grand Cal River to Lake Michigan } \\
\text { " }\end{array}$} \\
\hline & Hammond & & \multirow[t]{2}{*}{ I-90 Ramp } & & 0.285 & \\
\hline & & & & & 1.489 & \\
\hline
\end{tabular}




\section{Level 1 “Sensitive” Highway Segments in MS4s continued}

Sensitivity Level 1 Mileage in MS4s

Total State Level 1 Mileage

Percent Level 1 Mileage in MS4s

Level 1 Mileage Outside MS4s
88.1

365.2

$24.1 \%$

277.1

\footnotetext{
${ }^{1}$ Rule 13-MS4 Operator Listing (updated 3/18/04) at http://www.in.gov/idem/water/npdes/permits/wetwethr/storm/ms4oper.html ${ }^{2}$ Receiving waters for POTW and Combined Sewer discharge (updated 1/04) identified at http://www.in.gov/water/compbr/inspections/index.html. Separate storm sewer discharge assumed to be to the same receiving water. No designation of "receiving waters" means the MS4 collection system discharges to a neighboring community.
} 
Level 2 “Sensitive” Highway Segments in MS4s

\begin{tabular}{|c|c|c|c|c|c|c|}
\hline$\underline{\text { District }}$ & $\underline{\text { MS4 }}$ & MS4 Operator $^{1}$ & $\underline{\text { Hwy }}$ & $\underline{\text { Alt Name }}$ & $\begin{array}{c}\text { MS4 } \\
\text { Mileage }\end{array}$ & $\underline{\text { Receiving Waters }^{2}}$ \\
\hline Fort Wayne & Peru & Peru & US 24 & US 24 Bus. Rt. & $\frac{0.114}{0.114}$ & Wabash River \\
\hline \multirow[t]{4}{*}{ LaPorte } & $\begin{array}{l}\text { Crown Point } \\
\text { Crown Point }\end{array}$ & $\begin{array}{l}\text { Crown Point } \\
\text { " }\end{array}$ & $\begin{array}{l}\text { I-65 } \\
\text { SR } 53\end{array}$ & $\begin{array}{l}\text { Deep River Br. } \\
\text { Broadway }\end{array}$ & $\begin{array}{l}1.747 \\
0.939 \\
2.686\end{array}$ & $\begin{array}{l}\text { Beaver Dam Ditch to Deep River } \\
\text { " }\end{array}$ \\
\hline & $\begin{array}{l}\text { Gary } \\
\text { Gary } \\
\text { Gary } \\
\text { Gary }\end{array}$ & $\begin{array}{r}\text { Gary } \\
" \\
" \\
"\end{array}$ & $\begin{array}{l}\text { I-65 } \\
\text { I-65 } \\
\text { I-94 } \\
\text { Ramp }\end{array}$ & Deep River Br. & $\begin{array}{l}0.386 \\
1.304 \\
1.102 \\
2.249 \\
5.041\end{array}$ & $\begin{array}{c}\text { Grand Cal R. \& Little Cal R. } \\
\qquad " \\
" \\
"\end{array}$ \\
\hline & $\begin{array}{l}\text { Hobart } \\
\text { Hobart } \\
\text { Hobart } \\
\text { Hobart } \\
\text { Hobart } \\
\text { Hobart } \\
\text { Hobart } \\
\text { Hobart }\end{array}$ & $\begin{array}{c}\text { Hobart } \\
\text { " } \\
\text { " } \\
" \\
" \\
" \\
" \\
"\end{array}$ & $\begin{array}{l}\text { SR 130 } \\
\text { SR 51 } \\
\text { SR 51 } \\
\text { SR 51 } \\
\text { SR 51 } \\
\text { US 30 } \\
\text { US } 6 \\
\text { US } 6\end{array}$ & $\begin{array}{l}\text { W. Hwy } 130 \\
\text { E. } 3^{\text {rd }} \text { St } \\
\text { Grand Blvd } \\
\text { Lake Park Ave } \\
\text { Ripley St } \\
\text { W. US } 30 \\
\text { E. } 37^{\text {th }} \text { Ave } \\
\text { SR } 51\end{array}$ & $\begin{array}{l}0.398 \\
2.384 \\
0.303 \\
0.251 \\
2.698 \\
0.884 \\
0.798 \\
0.481 \\
8.197\end{array}$ & \\
\hline & $\begin{array}{l}\text { Lake Station } \\
\text { Lake Station } \\
\text { Lake Station } \\
\text { Lake Station } \\
\text { Lake Station }\end{array}$ & $\begin{array}{l}\text { Lake Station } \\
\qquad " \\
\text { " } \\
\text { " } \\
\text { " }\end{array}$ & $\begin{array}{l}\text { I-65 } \\
\text { I-94 Ramp } \\
\text { SR } 51 \\
\text { US } 51 \\
\text { US } 6\end{array}$ & $\begin{array}{l}\text { E. } 3^{\text {rd }} \text { St } \\
\text { Ripley St } \\
\text { SR } 51\end{array}$ & $\begin{array}{l}0.397 \\
5.615 \\
0.177 \\
0.118 \\
1.766 \\
8.073\end{array}$ & \\
\hline
\end{tabular}


Level 2 “Sensitive” Highway Segments in MS4s Continued

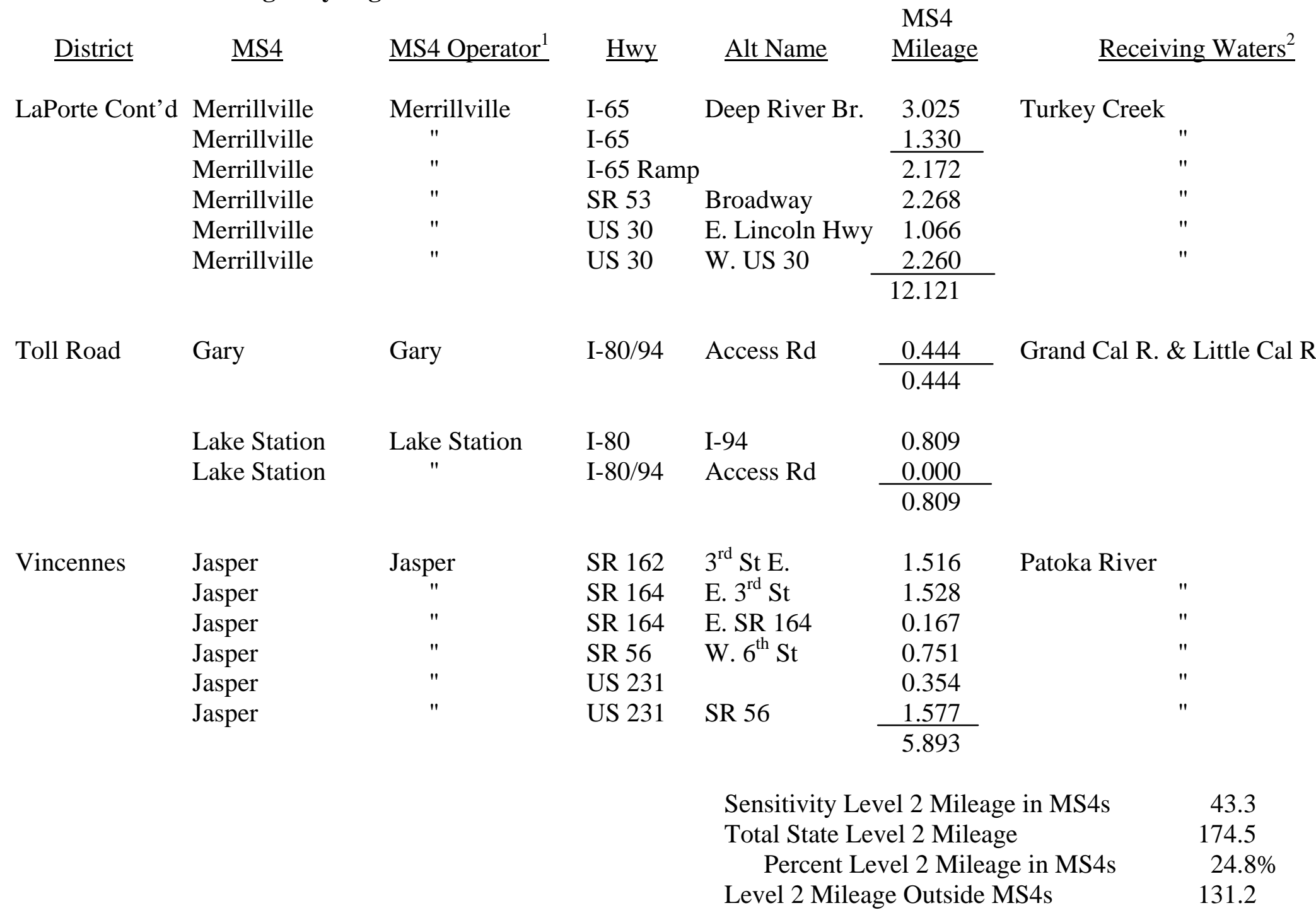

${ }^{1}$ Rule 13-MS4 Operator Listing (updated 3/18/04) at http://www.in.gov/idem/water/npdes/permits/wetwethr/storm/ms4oper.html ${ }^{2}$ Receiving waters for POTW and Combined Sewer discharge (updated 1/04) identified at http://www.in.gov/water/compbr/inspections/index.html. Separate storm sewer discharge assumed to be to the same receiving water. No designation of "receiving waters" means the MS4 collection system discharges to a neighboring community. 
LaPorte District, with 84 percent of the Level 1 sensitive highway segments and 85 percent of the Level 2 sensitive highway segments, should be the district receiving priority attention. Within LaPorte District, priority should be given to MS4s with the greatest "sensitive" highway segment mileage: Porter (24.8), Portage (22.9) and Michigan City (10.8), for Level 1, and Merrillville (12.1), Hobart (8.2) and Lake Station (8.1), for Level 2. Priority attention by INDOT to sensitive highway segments in these six MS4s will address 86.9 (66\%) of the 131.4 miles of the combined Level 1 and 2 sensitive highway segments in the state. 


\section{List of all known receiving waters or, if the discharge is to another MS4, the name of the MS4 entity and the initial receiving water.}

\section{A. Maintenance Facilities}

Historically, most contaminant loading of storm water runoff has been from three facility sources: (1) shop floor drain effluent of vehicle liquids accidentally spilled during vehicle repair; (2) truck washbay effluent, especially the washing of trucks that apply road salt during winter to prevent corrosion; and (3) from the active surface of the facility where salt/sand mixing, herbicide mixing-loading, asphalt (tar) kettle clean-out, highway paint mixing-loading and other activities preparatory to highway maintenance occur.

Today, vehicle maintenance, even fluid changes, is performed primarily at facilities that are connected to a POTW and/or have installed an oil/water separator. Truck washing is performed primarily at facilities that are connected to a POTW. And very few facilities perform highway maintenance preparatory activities on the active surface without implementing measures intended to prevent contaminant loading of storm water.

There are 59 maintenance facility locations in MS4 areas and 36 (61\%) of them are connected to a municipal Publicly-Owned Treatment Works (POTW) for the discharge of sanitary waste and shop floor drain and truck washbay wastewater effluent.

The ten criteria, listed below, evolved from the Rule 13 requirements and were used to identify the maintenance facilities in MS4s that require priority attention. The accompanying Table 5 identifies these facilities by District.

Criteria 1: maintenance facility locations within Rule 13 designated MS4 areas. 
Criteria 2: maintenance facility locations NOT connected to a POTW for discharge of shop floor drain and washbay effluent.

Criteria 3: maintenance facility locations within Karst areas.

Criteria 4: maintenance facility locations within 3,000 feet of a community public well.

Criteria 5: maintenance facility locations within (1,000 feet) (3,000 feet) (5,280 feet) of a public surface water intake.

Criteria 6: maintenance facility locations within one mile of high quality and exceptional use waters.

Criteria 7: maintenance facility locations within one mile of federal, state, county, municipal or township recreation facility having a lake, pond, river or stream.

Criteria 8: maintenance facility locations within 3,000 feet of groundwater that is highly vulnerable and very highly vulnerable to contamination by nitrates (as surrogate for chloride).

Criteria 9: maintenance facilities within 3,000 feet of a natural area containing Endangered, Threatened or Rare (ETR) species.

Criteria 10: maintenance facilities within one mile of the "best remaining examples of natural wetland communities,” as determined by IDNR. 
Table 5

Facilities in MS4 Areas Characterized by Selected Environmental Sensitivity Criteria

District and Facility

$\underline{\text { Crawfordsville }}$

Crawfordsville District

Crawfordsville Sub \& Unit

Terre Haute Sub \& Unit

Frankfort Sub \& Unit

Plainfield Unit

Ft. Harrison Unit

Lafayette Unit

Lebanon Unit

Fort Wayne

Fort Wayne District

Fort Wayne Sub \& Unit

Goshen Sub

Elkhart Sub \& Unit

Wabash Sub \& Unit

Angola Sub

New Haven Unit

U.S. 27 South Unit
$\mathrm{X}$

$\mathrm{X}$

$\mathrm{X}$

$\mathrm{X}$

$\mathrm{X}$

X $\quad X$

$X \quad X$

$\mathrm{X} \quad \mathrm{X}$

$\begin{array}{ll}\mathrm{X} & \\ \mathrm{X} & \\ \mathrm{X} & \\ \mathrm{X} & \\ \mathrm{X} & \\ X & X \\ \mathrm{X} & \mathrm{X} \\ \mathrm{X} & \mathrm{X}\end{array}$

\section{Criteria}

\begin{tabular}{llllllllll}
1 & 2 & 3 & 4 & 5 & 6 & 7 & 8 & 9 & 10 \\
\hline
\end{tabular}

\section{0}

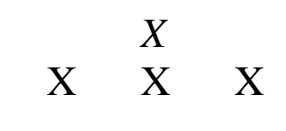

\section{Greenfield}

\begin{tabular}{|c|c|c|c|}
\hline Greenfield District & $\mathrm{X}$ & & \\
\hline Greenfield Sub & $\mathrm{X}$ & & \\
\hline Unit 2 (Tibbs) & $\mathrm{X}$ & & \\
\hline Unit $4\left(65^{\text {th }}\right.$ St. $)$ & $\mathrm{X}$ & & \\
\hline Unit 5 (Madison) & $\mathrm{X}$ & & \\
\hline Anderson Unit & $\mathrm{X}$ & & \\
\hline Shelbyville Unit & $\mathrm{X}$ & & \\
\hline Richmond Unit & $\mathrm{X}$ & & \\
\hline Alexandria Unit & $\mathrm{X}$ & & \\
\hline Muncie Unit & $\mathrm{X}$ & & \\
\hline Indianapolis Sub \& 2 Units & $X^{1} \quad X$ & $X$ & \\
\hline Unit $3\left(71^{\text {st }}\right.$ St. $)$ & $X^{1} \quad X$ & & $\mathrm{X}$ \\
\hline Kokomo Unit & $X^{1} \quad X$ & & \\
\hline Westfield Unit & $\mathrm{X}^{1} \quad \mathrm{X}$ & & \\
\hline
\end{tabular}


District and Facility

LaPorte

LaPorte District

LaPorte Sub \& Unit

New Gary Sub

Valparaiso Unit (closed)

Chesterton

Logansport Unit

South Bend Unit

Mishawaka Unit

Old Gary Sub (inactive)

Crown Point Unit

Miller Unit

Michigan City Unit

$\underline{\text { Seymour }}$

Seymour District

Bloomington Sub \& Unit

Columbus Sub \& Unit

Sellersburg Sub \& Unit

New Albany Unit

Greensburg Unit

Madison Sub

$\underline{\text { Vincennes }}$

Jasper Unit

Evansville Sub \& Unit 2

Evansville Unit 1

Chandler Unit

Washington Unit

Bedford Unit

Toll Road

Lake Maintenance

Porter Maintenance

Elkhart Maintenance

Toll Road District \begin{tabular}{llllllllll}
1 & 2 & 3 & 4 & 5 & 6 & 7 & 8 & 9 & 10 \\
\hline
\end{tabular}

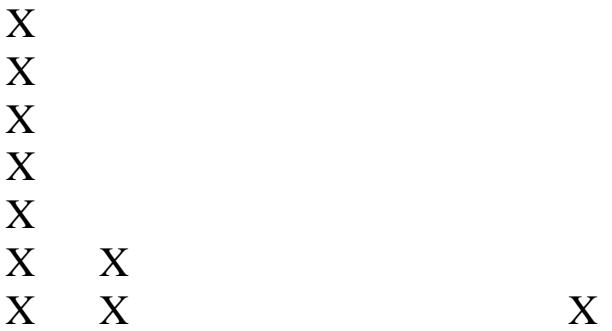

$\mathrm{X}$

$\mathrm{X}$

$\mathrm{X}$

$\mathrm{X}$

$\mathrm{X}$

X $\quad X \quad X \quad X$

[Italics]: currently connected for discharge of sanitary only 
Summary: MS4 Facility Criteria Totals, by District

\begin{tabular}{|c|c|c|c|c|c|}
\hline & & & & & \\
\hline st & 2 & 3 & 4 & 5 & 6 \\
\hline
\end{tabular}

\begin{tabular}{lcccccccccccc} 
Crawfordsville & 8 & 3 & 0 & 0 & 0 & 0 & 1 & 2 & 1 & 0 & 15 & 3 \\
Fort Wayne & 8 & 1 & 0 & 3 & 0 & 0 & 2 & 4 & 2 & 0 & 20 & 2 \\
Greenfield & 14 & 4 & 0 & 1 & 0 & 0 & 0 & 1 & 0 & 0 & 20 & 2 \\
LaPorte & 12 & 9 & 0 & 2 & 0 & 1 & 1 & 4 & 3 & 2 & 34 & 1 \\
Seymour & 7 & 2 & 0 & 1 & 0 & 0 & 1 & 0 & 0 & 0 & 11 & 4 \\
Vincennes & 6 & 1 & 1 & 0 & 0 & 0 & 0 & 1 & 1 & 0 & 10 & 5 \\
Toll Road & 4 & 3 & 0 & 2 & 0 & 0 & 0 & 3 & 3 & 0 & 15 & 3 \\
\multicolumn{1}{c}{ Totals } & 59 & 23 & 1 & 9 & 0 & 1 & 5 & 15 & 10 & 2 & 125 &
\end{tabular}

INDOT Facilities in MS4 Areas to Which Priority Attention Should be Directed, by

\section{$\underline{\text { District }}$}

\section{Crawfordsville}

Lafayette Unit: not connected to POTW; 1 mile of recreation waters; 3,000' of vulnerable groundwater; 3,000' of an ETR natural area;

\section{Fort Wayne}

Fort Wayne District, Sub and Unit: 3,000' of community public well; 1 mile of recreation waters; 3,000' of vulnerable groundwater; 3,000' of an ETR natural area; U.S. 27 South Unit: not connected to POTW; 3,000' of community public well; 3,000’ of vulnerable groundwater;

\section{Greenfield}

Indianapolis Sub and 2 Units: not connected to a POTW; 3,000' of a community public well [replacement facilities being constructed in 2004] 
Indianapolis Unit $3\left(71^{\text {st }} \mathrm{St}\right)$ : not connected to POTW; 3,000' of vulnerable groundwater;

\section{$\underline{\text { LaPorte }}$}

Mishawaka Unit: not connected to POTW; 3,000' of community public well; 1 mile of recreation waters;

Chesterton Unit: not connected to POTW; 3,000' of community public well; 1 mile of high quality and exceptional use waters;

\section{$\underline{\text { Seymour }}$}

Madison Sub: not connected to POTW; 1 mile of recreation water;

\section{$\underline{\text { Vincennes }}$}

Bedford Unit: located in karst area; 3,000' of vulnerable groundwater; 3,000' of an ETR natural area;

\section{$\underline{\text { Toll Road }}$}

Toll Road District: not connected to POTW; 3,000' of community public well; 3,000' of vulnerable groundwater; 3,000' of an ETR natural area;

Elkhart Maintenance: not connected to POTW; 3,000' of community public well; 3,000' of vulnerable groundwater; 3,000' of an ETR natural area;

Porter Maintenance: not connected to POTW; 3,000' of vulnerable groundwater; 3,000' of an ETR natural area.

\section{B. Highways}

Current INDOT policy regarding maintenance of highway drainage systems derives from statutes adopted in the 1930's. The most current policy issuance identified (revised 1/10/92) is based on IC 8-23-6, which states, in part: 
Section 1.(c) As part of the construction work, the department shall construct within the limits of a street the curbs and gutters, manholes, catch basin, and the necessary drainage structures and facilities (underline added);

Section 2. If the construction of a street necessitates the construction of adequate connecting facilities outside the limits of the street to provide for drainage of the street, the necessary mains, laterals, and connections shall be provided for in the plans, included as part of the construction cost, and paid out of the department's appropriation (underline added);

Section 3. (d) Upon the completion of a street, the department shall maintain the roadway of the street, including the curbs and gutters, catch basins, and inlets within the limits of the street or highway that form integral parts of the street or highway. The city or town shall maintain the sidewalks, grass plats, and the connecting drainage facilities (underline added).

The 1992 policy clarifies the statute:

"The Indiana Department of Transportation will be responsible for maintaining the inlets, catch basins, manholes and the connecting pipes between them, including the pipe to the main sewer line. The city or town will maintain the main storm sewer line, its manholes and/or other related appurtenances to the main sewer line” (underline added).

This "sharing” of drainage systems will undoubtedly cause confusion in some MS4 communities. In response to an emailed question posed by the Principal Investigator on May 12, 2003, an IDEM storm water official replied: 
"To answer your question, if an outfall is located in one MS4 entity and a second MS4 entity has a conveyance which leads to this outfall, the second MS4 entity is only responsible to the point they have jurisdiction ... If the other MS4 entity is regulated under Rule 13, they will be responsible for characterizing the receiving water that the outfall discharges into, but they can also attribute some part of the pollutant loading to the contributing MS4 entity.”3

Storm water runoff from state-maintained highways is collected, typically, by two types of "systems:"

(1) Inlets $\longrightarrow$ Catch Basins $\longrightarrow$ Connecting Drains $\longrightarrow$ Municipal Sewer Pipe $\longrightarrow$

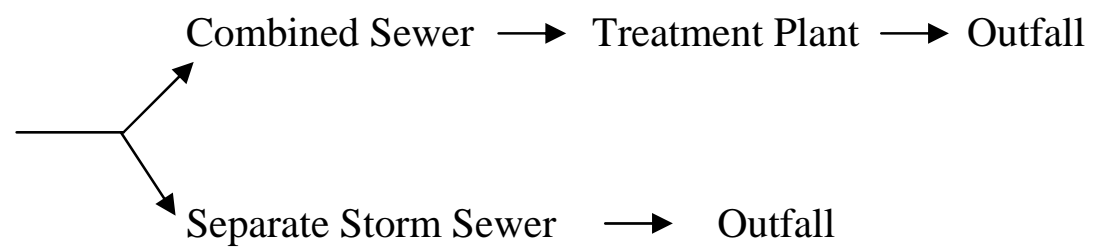

(2) Side Ditch
Resides in Ditch (Absorbed/Evaporates)
Constructed Drain

The first system is that to which the storm water from approximately 1,662 "urban" miles (15\%) of the total 11,216 miles of state-maintained highways discharges; the storm water from the remaining 9,554 "rural" miles (85\%) is collected by side ditches and is (1) conveyed by a system of side ditches but never reaches the "waters of the state -- being absorbed or retained until evaporated; (2) conveyed by side ditches and constructed drains to "waters" of the state;" and (3) conveyed to a constructed wetland or retention pond.

${ }^{3}$ Email communication, “MARK BALAZS”<MBALAZS@dem.state.in.us, 10:10AM 5/14/2003. 
The study first investigated the storm water collection system that discharges to a municipal combined or separate storm sewer system. A directory of municipal POTW operators previously compiled by the Principal Investigator was used to identify MS4 communities with and without combined systems. The directory is found in Appendix F [www.ecn.purdue.edu/CMTI/INDOT]

The INDOT policy and the IDEM affirmation of the Rule 13 requirements prompted the Principal Investigator to prepare a questionnaire (next page) to be mailed to the 106 municipalities that operate combined sanitary/storm sewer systems. The replies identify highway segments in 31 communities that discharge to municipal combined sanitary/storm sewers. A total of 138 miles of state highway segments were identified by the 31 municipalities, 113 miles (82\%) of this total mileage is in the 21 MS4 municipalities responding to the survey. [Appendix G] 


\section{Survey of Indiana Municipalities with Combined Sanitary and Storm Sewer Collection Systems}

Survey Form Completed by:

Telephone Number:

(person's name)

Municipality:

Address:

A. Please identify any state highway segments that discharge storm water to your combined sanitary/storm sewer collection system (use the common State Route - SR - number, like SR 39, and the local name or identification of this segment, like Pine Street):

State Route No.

Local Name

1.

2.

3.

4.

5 .

B. For each of the above, please identify the end points of the segment (like from Oak Street to County Road 200 East) and the approximate length, in miles and/or tenths of miles:

End Points

Approx.

Length

1. from:

to:

2. from:

to:

3. from:

to:

4. from:

to:

5. from:

to: 
C. And, for each of the above, please check ( $\checkmark$ ) whether the discharge is run-off (sheet flow) from the highway pavement surface, or is a direct discharge from the highway drainage system (including side ditches, culverts, drain pipes and catch basins):

$\begin{array}{lllll}\text { Run-Off } & \text { Side Ditch } & \text { Culvert } & \text { Drain Pipe } \\ \text { 1. } & & & \\ 2 . & \square & & \\ 3 . & \square & \square & \square \\ 4 . & \square & \square & \square\end{array}$

Thank you for your assistance with this survey. Please return to:

Lynn A. Corson, Ph.D.

2655 Yeager Road, Suite 103

West Lafayette, IN 47906 
Receiving waters for the discharge of storm water collected by combined sewer systems from MS4 sources and Level 1 and 2 sensitive highway segments are identified in Tables 3 and 4 on pages 17 (“Level 1') and 21 (“Level 2"). Most of the identified receiving waters -- the initial or secondary water -- are "sensitive" waters, as identified in Section III of this report.

The storm water from highway segments not collected by MS4 combined or separate storm sewer system that reaches waters of the state does so through outfalls that are the termini of side ditches or constructed drains at the bridges that cross over these waters. The location of each state-maintained bridge, by highway mile marker and name of the waterway the bridge crosses over, is found in the CD-ROM included here as Appendix H.

- Also, INDOT's water quality monitoring program, discussed in Section IV, employs hand-held "sonde" instruments to monitor all waters crossed by bridges on Level 1 and Level 2 sensitive highway segments. At each monitoring point, the latitude/longitude is recorded, using a hand-held GPS unit accurate to within 5 meters.

INDOT is currently inventorying its "small culverts," under four feet in diameter, and "large culverts," over four feet, up to 20 feet in diameter. The location of some is identified by GPS, and others by mile marker and highway. The inventory does not include the name of the nearest waterway, so any drains that can be considered outfalls to waters of the state will need to be identified from these and other data. ${ }^{4}$

\footnotetext{
${ }^{4}$ Email correspondence with TMCCLELLAN@indot.state.in.us in April 2004.
} 


\section{Identification of Known Sensitive [Water] Areas}

The Baseline Characterization analysis included in Rule 13 requires,

"The identification of known sensitive [water] areas, such as public swimming areas, surface drinking water intakes, waters containing threatened or endangered species and their habitat, or state outstanding resource and exceptional use waters. The identified sensitive areas should be given the highest priority for the selection of BMPs [Best Management Practices] and the prohibition of new or significantly increased MS4 discharges.”

INDOT, as an MS4 operator, is expected to identify these "sensitive [water] areas" and to implement minimum control measures "to ensure that existing ... state ... operations are performed in ways that will reduce contamination of storm water discharges.” [327 IAC 15-13-17(b)].

Control measures for highways include reducing the amount of salt applied for deicing or applying brine for anti-icing; modifying highway design, construction and maintenance standards and procedures to reduce contaminated storm water discharge as highway drainage or pavement run-off to the "waters of the state" or reduce the contaminant loading of the storm water, itself; and installing or constructing structural best management practices (BMPs) to reduce contaminate loading.

Section 17(b)(2) of Rule 13 requires the implementation of, "controls for reducing or eliminating the discharge of pollutants from operational areas, including roads, parking lots, maintenance and storage yards, and waste transfer stations," such as:

(A) Covering, or otherwise reducing, the potential for polluted storm water run-off from deicing salt or sand storage piles. 
(B) Establishing designated snow disposal areas that have minimal potential for pollutant run-off impact on MS4 receiving waters.

(C) Providing facilities for containment of any accidental losses of concentrated solutions, acids, alkalies, salts, oils, or other polluting materials.

(D) Standard operating procedures for spill prevention and clean up during fueling operations.

(E) BMPs for vehicular maintenance areas.

(F) Prohibition of equipment or vehicle wash waters and concrete or asphalt hydrodemolition wastewaters into storm water run-off, except under the allowance of an appropriate NPDES wastewater permit.

(G) Minimization of pesticide and fertilizer use. Pesticides shall be used, applied, handled, stored, mixed, loaded, transported, and disposed of via Office of the Indiana State Chemist’s guidance requirements.

(H) Proper disposal of animal waste. If applicable, it is recommended that canine parks shall be sited at least one hundred fifty (150) feet away from a surface water body.

The four criteria established for identifying "sensitive [water] areas” are found in Rule 13 at 327 IAC 15-13-5 (70). Each of the four criteria is defined below.

\section{(A) having threatened or endangered species or their habitat;}

Indiana’s Department of Natural Resources created a GIS database known as the “Natural Areas and Endangered, Threatened and Rare (ETR) Species” database. The acquisition of this database requires a special arrangement with DNR Natural Heritage Data Center. Species having state or federal designations of endangered, threatened, rare, special concern, extirpated or on a "watch list" are identified by generic descriptor (bird, mammal, 
etc.), heritage species code and are located by latitude and longitude in decimal degrees, as well as by county and watershed.

\section{(B) usage as a public surface water supply intake;}

A GIS database of public surface water supply intakes has been merged by Purdue with the INDOT facilities and state highways databases to produce a GIS map which readily depicts the proximity of the INDOT properties to the intakes.

\section{(C) usage for full-body contact recreation, such as bathing beaches;}

This criteria was originally identified as "relevant community value," which was defined in the proposed Rule 13 Guidance Manual (February 2002) as “an area, both land and water, that is deemed important by local municipal, state or federal governments for their recreational value.” These areas can be used for full-body contact activities, such as swimming and water skiing. A GIS database of state/federal/local public recreation areas with water bodies has been merged with a database of maintenance facilities and statemaintained highways.

(D) exceptional use classification as found in 327 IAC 2-1-11(b) or outstanding state resource water classification [also designated as "high quality waters"] as found in 327 IAC 2-1-2(3) and 327 IAC 2-1.5-19(b).

The Indiana Department of Environmental Management Office of Water Quality maintains GIS databases which identify the river and stream segments included in the above citations. Purdue has merged these databases with the INDOT facilities and highway databases and produced GIS maps that depict the proximity of the INDOT properties to the rivers and streams. A description of the GIS layers referenced above is found in Appendix I. 
Indiana’s Natural Resources Commission, in 1993, promulgated its “Outstanding Rivers List for Indiana.” It is the state’s “umbrella” list of rivers and streams "which have particular environmental or aesthetic interest.”

The Outstanding Rivers list and its corollary databases served as the primary criteria for the establishment of the four "sensitivity levels" used for identifying state-maintained highway segments in environmentally sensitive areas; primarily within one mile of designated "priority" rivers and streams. The first three sensitivity levels are based on the "Priority” river and stream segments identified in Appendix J of this report.

The Priority 1 table includes 23 river and stream segments, 17 of which are Exceptional Use Waters and High Quality Waters (also known as Outstanding State Resource Waters). The remaining 6 segments are eligible for these designations.

The second table to the Appendix, "INDOT Priority No. 2," is comprised of "rivers identified as having outstanding ecological, recreational or scenic importance.” There are 11 segments included on this list. None are currently on the Rule 13 "sensitive [water] areas" lists cited, but they may be added in the future or, subsequently, be considered by IDEM to be "sensitive [water] areas" for the purpose of NPDES permitting.

The third table in Appendix I, identified as “INDOT Priority No. 3,” contains 26 river and stream segments, none of which are currently included in the Rule 13 "sensitive [water] areas" lists cited, but are segments "identified by state natural heritage programs or similar state programs as having outstanding ecological importance.” These, too, may be added to the "sensitive [water] areas" list or, subsequently, be considered by IDEM to be such for the purpose of NPDES permitting.

The fourth sensitivity level includes highway segments that are not within one mile of a Priority 1, 2 or 3 river or stream but are within 1 mile of any of the other sensitivity criteria, singularly or in combination (two or three criteria, together). The other criteria: (1) natural 
area having Endangered, Threatened or Rare (ETR) species; (2) public surface water supply intake (WTRIN) and (3) public recreation facility with water body used for full-body recreation (RECFAC), are also subsets of the first three sensitivity levels. follows:

Sensitivity criteria are coded in the following tables for each Sensitivity Level, as

"1" - -highway segments within 1 mile of a Priority 1 stream

"2" -highway segments within 1 mile of a Priority 2 stream

"3" - -highway segments within 1 mile of a Priority 3 stream

"4" -highway segments not within 1 mile of a Priority 1, 2, or 3 stream, but within 1 mile of other sensitivity criteria

"A" -highway segments inside karst areas

"B" -highway segments outside karst areas

Other sensitivity criteria include:

-1 within 1 mile of natural area having ETR [ETR] and within 1 mile of public surface water supply intake [WTRIN] and within 1 mile of public recreation facility with water body used for full-body recreation [RECFAC]

-2 within 1 mile of ETR and WTRIN

-3 within 1 mile of ETR $\underline{\text { and }}$ RECFAC

-4 within 1 mile of RECFAC and WTRIN

$-5 \quad$ within 1 mile of WTRIN

-6 within 1 mile of ETR

$-7 \quad$ within 1 mile of RECFAC

-8 no other analyses

Highway segments within 1 mile of a Priority 1 stream are coded "1." If those same highway segments are within karst areas, they are coded "A." Those same highway segments within 1 mile of a natural area having Endangered, Threatened, or Rare (ETR) 
species will be coded "-6." The table for Seymour District highways, for example, shows 21.0 miles of highway segments coded 1A-6.

The complete description of sensitivity codes follows. Codes are used, along with colors, to designate highway segments on the GIS maps for each District and Subdistrict. The MS4 "Sensitive” Highway Segments categorized by sensitivity level, for each District, are identified in Appendix K.

\section{$\underline{\text { Sensitivity Level } 1}$}

1. Highway segments within 1 mile of-

Priority 1 streams, and

A. within Karst areas, and

-1 within 1 mile of natural area having ETR [ETR] and within 1 mile of public surface water supply intake [WTRIN] and within 1 mile of public recreation facility with water body used for full-body recreation [RECFAC]

-2 within 1 mile of ETR and WTRIN

-3 within 1 mile of ETR and RECFAC

-4 within 1 mile of RECFAC and WTRIN

-5 within 1 mile of WTRIN

-6 within 1 mile of ETR

-7 within 1 mile of RECFAC

-8 no other analyses

B. outside Karst areas, and

-1 within 1 mile of natural area having ETR [ETR] and within 1 mile of public surface water supply intake [WTRIN] and within 1 mile of public recreation facility with water body used for full-body recreation [RECFAC]

-2 within 1 mile of ETR and WTRIN

-3 within 1 mile of ETR and RECFAC

-4 within 1 mile of RECFAC and WTRIN 
-5 within 1 mile of WTRIN

-6 within 1 mile of ETR

-7 within 1 mile of RECFAC

-8 no other analyses

\section{Sensitivity Level 2}

2. Highway segments within 1 mile of-

Priority 2 streams, and

A. within Karst areas, and

-1 within 1 mile of natural area having ETR [ETR] and within 1 mile of public surface water supply intake [WTRIN] and within 1 mile of public recreation facility with water body used for full-body recreation [RECFAC]

-2 within 1 mile of ETR and WTRIN

-3 within 1 mile of ETR and RECFAC

-4 within 1 mile of RECFAC and WTRIN

-5 within 1 mile of WTRIN

-6 within 1 mile of ETR

-7 within 1 mile of RECFAC

-8 no other analyses

B. outside Karst areas, and

-1 within 1 mile of natural area having ETR [ETR] and within 1 mile of public surface water supply intake [WTRIN] and within 1 mile of public recreation facility with water body used for full-body recreation [RECFAC]

-2 within 1 mile of ETR and WTRIN

-3 within 1 mile of ETR and RECFAC

-4 within 1 mile of RECFAC and WTRIN

-5 within 1 mile of WTRIN

-6 within 1 mile of ETR 
-7 within 1 mile of RECFAC

-8 no other analyses

\section{$\underline{\text { Sensitivity Level } 3}$}

3. Highway segments within 1 mile of-

Priority 3 streams, and

A. within Karst areas, and

-1 within 1 mile of natural area having ETR [ETR] and within 1 mile of public surface water supply intake [WTRIN] and within 1 mile of public recreation facility with water body used for full-body recreation [RECFAC]

-2 within 1 mile of ETR and WTRIN

-3 within 1 mile of ETR and RECFAC

-4 within 1 mile of RECFAC and WTRIN

-5 within 1 mile of WTRIN

-6 within 1 mile of ETR

-7 within 1 mile of RECFAC

-8 no other analyses

B. outside Karst areas, and

-1 within 1 mile of natural area having ETR [ETR] and within 1 mile of public surface water supply intake [WTRIN] and within 1 mile of public recreation facility with water body used for full-body recreation [RECFAC]

-2 within 1 mile of ETR and WTRIN

-3 within 1 mile of ETR and RECFAC

-4 within 1 mile of RECFAC and WTRIN

-5 within 1 mile of WTRIN

-6 within 1 mile of ETR

-7 within 1 mile of RECFAC

-8 no other analyses 


\section{Sensitivity Level 4}

4. Highway segments not within 1 mile of-

Priority 1, 2, or 3 streams, but

A. within Karst areas, and

-1 within 1 mile of natural area having ETR [ETR] and within 1 mile of public surface water supply intake [WTRIN] and within 1 mile of public recreation facility with water body used for full-body recreation [RECFAC]

-2 within 1 mile of ETR and WTRIN

-3 within 1 mile of ETR and RECFAC

-4 within 1 mile of RECFAC and WTRIN

-5 within 1 mile of WTRIN

-6 within 1 mile of ETR

-7 within 1 mile of RECFAC

-8 no other analyses

B. outside Karst areas, and

-1 within 1 mile of natural area having ETR [ETR] and within 1 mile of public surface water supply intake [WTRIN] and within 1 mile of public recreation facility with water body used for full-body recreation [RECFAC]

-2 within 1 mile of ETR and WTRIN

-3 within 1 mile of ETR and RECFAC

-4 within 1 mile of RECFAC and WTRIN

-5 within 1 mile of WTRIN

-6 within 1 mile of ETR

-7 within 1 mile of RECFAC

Note: $\quad$ 4B-8 does not exist as a coded criteria as it represents highway segments, not within 1 mile of Priority 1 , 2, or 3 streams, outside karst and not within 1 mile of any other sensitivity criteria; therefore, it is "not applicable" (n/a) in the table, under 4B-8, but this total is shown as "total non-sensitive mileage" in the bottom line of the last page of each District table. 


\section{Monitoring Data for the MS4 Area Receiving Waters}

INDOT's Environmental Services Section initiated a water quality monitoring project in June 2003. An expansion of this JTRP study, to allow the purchase of two YSI Sondes and two hand-held GPS units, facilitated monitoring Priority 1 of waters of the state from 60 locations, usually bridges, including:

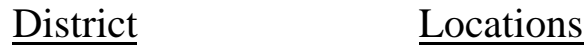

Crawfordsville

Fort Wayne

Greenfield

LaPorte

Seymour

Vincennes

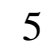

2

21

10

6

Water quality monitoring parameters included temperature, conductivity, dissolved oxygen (DO), $\mathrm{pH}$, oxidation reduction potential (ORP), and turbidity. Chloride concentration was not recorded, as originally intended, because of the complicated calibration procedure required.

INDOT will repeat the monitoring of Priority 1 waters during the summer 2004. Priority 2 waters will also be monitored and stream samples will be collected from many locations for subsequent chloride testing, using Quantabs, a litmus-type strip, commonly used in the food industry.

Monitoring data and maps identifying the monitoring locations are included in the CD-ROM identified as Appendix L. 
$\underline{\text { USGS Real-time Flow Gauge and Fixed Surface Water Quality Monitoring Station }}$

$\underline{\text { Data }}$

The CD-ROM, included here as Appendix M, is also available at this website: www.ecn.purdue.edu/CMTI/stormwater/SWQMP_FSWQM.htm. As described at the website, the web resource spreadsheet was organized to allow municipal MS4s to access data, via hyperlinks, that otherwise can be a complicated, time-consuming task. The spreadsheet also presents INDOT’s water quality monitoring data (from Appendix L) with USGS real-time flow gauge data and IDEM fixed surface water quality monitoring station data. The spreadsheet provides USGS and IDEM monitoring data from sites within 10 miles up- and down-stream of an INDOT monitoring site on the same waterway.

INDOT will rely on this and comparable websites to provide access to water quality data for use as the baseline characterization of waters that could receive storm water from its highways and maintenance facilities. ${ }^{5}$ According to Rule 13, if storm water quality impairments are identified, measures must be implemented to correct the impairments. These measures can include structural best management practices (BMPs) or nonstructural BMPs, such as the elimination of, or a change in, a function or practice that contributes to the impairment.

\footnotetext{
${ }^{5}$ Another useful website is the Hoosier Riverwatch database at http://www.hoosierriverwatch.com/search.html
} 


\section{Modifying MS4 Area Designation of Receiving Waters}

Designations of "receiving waters" for storm water from INDOT highways and facilities is based, primarily, on GIS and other database analyses. On-site inspections of facilities and human judgment applied to the findings of such inspections will be the final determinant of how a "receiving water" is defined.

The designation of "sensitive” highway segments, in the INDOT Water Quality and Characterization model, is based on the proximity of the segment to a "sensitive" water body, listed by the DNR Commission as an Outstanding State Resource Water or Exceptional Use Water or is eligible for such listing. Other criteria for identifying “sensitive” water areas include: 1) those having endangered, threatened or rare species or their habitat; 2) those used as a public surface water supply intake, and 3) those used for full-body contact recreation (swimming).

There are natural (topographic and geological) and constructed features that may exist in the area between the designated highway segment and the "sensitive" water body that could reduce the amount of contaminants in storm water runoff that reaches the water body (e.g., vegetation serving as a filter strip). Such features may also reduce the volume of storm water runoff or actually prevent it from reaching the water body (e.g., slope between the highway and water body, if the highway was down-gradient of the water body).

Constructed features that could reduce the amount of contaminants and/or the volume of storm water runoff will usually be those constructed by INDOT during highway construction or the maintenance following construction. Primary among these features are the highway storm water conveyance systems. 
Consideration of these systems should include:

1. side ditch

a) prevalence/type/density of vegetation in the ditch;

b) natural (e.g., clay) or constructed (e.g., rip-rap) barriers in the walls of the side ditch preventing runoff to the water body;

c) the terminus of the side ditch, if other than the water body, and the distance to the water body from the terminus;

2. constructed culvert or pipe

a) terminus, if other than the water body, and distance from the terminus to the water body;

3. other type of storm water conveyance

a) terminus, if other than the water body, and distance from the terminus to the water body;

b) construction materials used

4. bridge drains that discharge directly to a water body

A checklist of the various criteria can be formatted and used in inspecting the designated “sensitive” highway segments:

\section{Natural Features}

distance to the water body

slope between the highway and water body

soil type and percolation rate

vegetation type/density (ability to filter or retard runoff)

\section{Constructed Features}

prevalence/type/density of vegetation in a side ditch 
materials serving as barriers (clay, rip-rap, paving, etc.) in the walls of the side ditch

slope of the ditch walls

type of culvert construction or drain pipe

terminus of the side ditch, culvert or drain pipe if not the water body, and distance from the terminus to the water body

The baseline characterization, through water quality monitoring, will be modified for highway storm water runoff using "checklists" or log sheets like those on the following pages. The use of the checklists will enable a determination as to whether runoff actually reaches waters of the state. The summer 2003 water quality monitoring record (Appendix L) includes “comments" indicating that either there is an intermittent receiving water or that topographical or other factors prevent runoff from reaching the waters of the state.

The “INDOT Facility Storm Water and Washwater Effluent Drainage Assessment" (pages 53 to 55) is a current version of an assessment form employed during facility site visits over many years. The SPR 2854 study recently implemented will use this and other tools to characterize facilities and determine (1) if storm water runoff or discharge reaches waters of the state, (2) if it is contaminated with pollutants, and (3) the source of those contaminants. ${ }^{6}$

\footnotetext{
“'Deriving the Cost Impacts of Indiana's Storm Water Rule 13 on INDOT Maintenance Facility Operations,” JTRP Project Number: C-36-78W, File Number: 04-07-23, SPR 2854, January 1, 2004 - June 30, 2006
} 


\section{Checklist for Determining the Impact of Highway Storm Water Run-off or Discharge to Waters of the State}

Note: The assessment of a sensitive highway segment that results in one or more of the below characteristics being "checked," in the applicable Run-off or Discharge section, will exempt that segment from the list of sensitive highway segments in INDOT's Storm Water Quality Management Plan.

District/Subdistrict/Unit:

State Highway Name:

Sensitive Segment Location :

Below are listed CHARACTERISTICS of the space (1) between the highway R/W and the sensitive waterbody, and (2) between the end of the pipe or ditch and the sensitive waterbody that, in all likelihood, PREVENT storm water from REACHING the sensitive waterbody.

1. "Run-off" means storm water that flows from the highway R/W and is NOT contained by a pipe or ditch. [Check all those that apply].

distance is 100 feet or more

slope is less than 18 percent

type, density and/or height of vegetation (explain:

type and assumed absorption capacity of the soil (explain:

2. "Discharge" means the contained flow of highway R/W storm water run-off from the end of a pipe or ditch. [Check all those that apply].

distance is feet or more

slope is less than percent type, density and/or height of vegetation (explain:

type and assumed absorption capacity of the soil (explain:

type, density and/or height of vegetation in the ditch (explain:

3. If bridges exist on this highway segment:

storm water from the deck does NOT drain to the waterbody, below 


\section{Sensitive Waters Evaluation Procedures INDOT Storm Water Management Plan}

May 15, 2003

1. Highway discharges to Sensitive Waters will be evaluated and tested.

2. Use the Log Sheets to help evaluate where to test.

a. Fill out the upper portion; District, Highway, County, Water body, Staff (Your Name), Date, Ref. Post \# + Offset (Small Blue Sign at Bridge), Log Mile, \& USGS Quad Map.

b. The sheet is designed for a highway/stream crossing, with four quads to evaluate, i.e. NW, NE, SE, SW. Start at the northwest quad and proceed clockwise.

c. Write number of feet of conveyance in the appropriate row and column, or "None". If there is a pipe, give its measure its length and diameter.

d. Determine the discharge point locations using the GPS Navigator and write that in the Latitude and Longitude rows.

e. Make note of Bridge Deck Drains, how many, what size, spacing length, diameter, which side of deck, on both decks (in a divided highway situation).

f. Comments: is there erosion problems, is there illicit discharge onto the right-of-way and where, did you probe a discharge pipe from the median, are there other adjacent discharges to the stream, side-slope length, sideslope vegetation, side-slope slope $(2: 1,3: 1,4: 1)$. If there are pipes, note where they come from and discharge to.

3. Equipment list: Measuring Wheel

Tape measure for pipe diameter, 16 ' or $25^{\prime}$ adequate

Shovel

YSI Probe

GPS Navigator

Bucket

Extension Pole (to hold bucket up to bridge deck drain outlet, under bridge)

4. Wear a INDOT safety vest at all time when on the right-of-way, out of the car. 
Sensitive Waters Log Sheet

INDOT Storm Water Management Plan

District:

Staff:

Date:

Highway:

USGS

County:

Quadrangle:

Water body:

Reference

Post \# + Offset: $+$

Log Mile:

\begin{tabular}{|l|l|l|l|l|}
\hline Conveyance & Quad: & Quad: & Quad: & Quad: \\
\hline Pipe & & & & \\
\hline Paved & & & & \\
\hline Grassy & & & & \\
\hline Riprap & & & & \\
\hline
\end{tabular}

Discharge Point

\begin{tabular}{|l|l|l|l|l|}
\hline Latitude & & & & \\
\hline Longitude & & & & \\
\hline
\end{tabular}

Bridge Deck Drains:

\section{Comments:}


Date

INDOT Facility Stormwater and Washwater Effluent Drainage Assessment

Name of Facility

District/Subdistrict

\section{$\underline{\text { Surface Water }}$}

1. Does any area of the active surface collect storm water or facility-generated wash water (such as from washing trucks outdoors)?

2. Is there any movement of surface water from one area to another on-site by ditch, drain tile or natural channel?

3. Is there any movement of surface water off-site (e.g., beneath the perimeter fence) via sheet flow, ditch, pipe or channel to neighboring property?

4. Is the surface water discharged directly to -

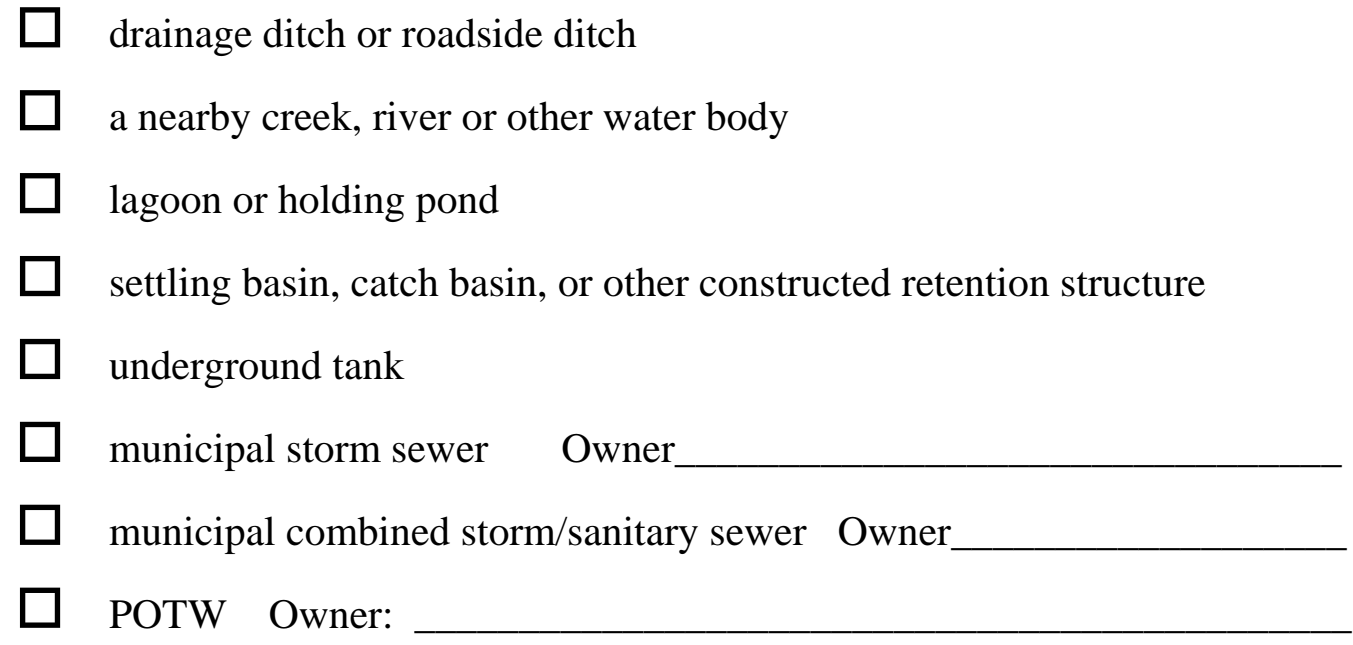

5. If surface water is discharged, other than to a municipal storm, sanitary or combined sewer, does it ultimately reach "waters of the state" (e.g., farm ditch, creek, stream, river, lake or pond)? If yes, name of nearest water body.

6. What is the estimated distance of this water body from the facility? 


\section{Shop Floor Drain \& Wash Bay Effluent}

1. Are there drains in shop floors and wash bays that remove liquids and wash water from the building(s)?

2. Do liquids and wash water flow to -

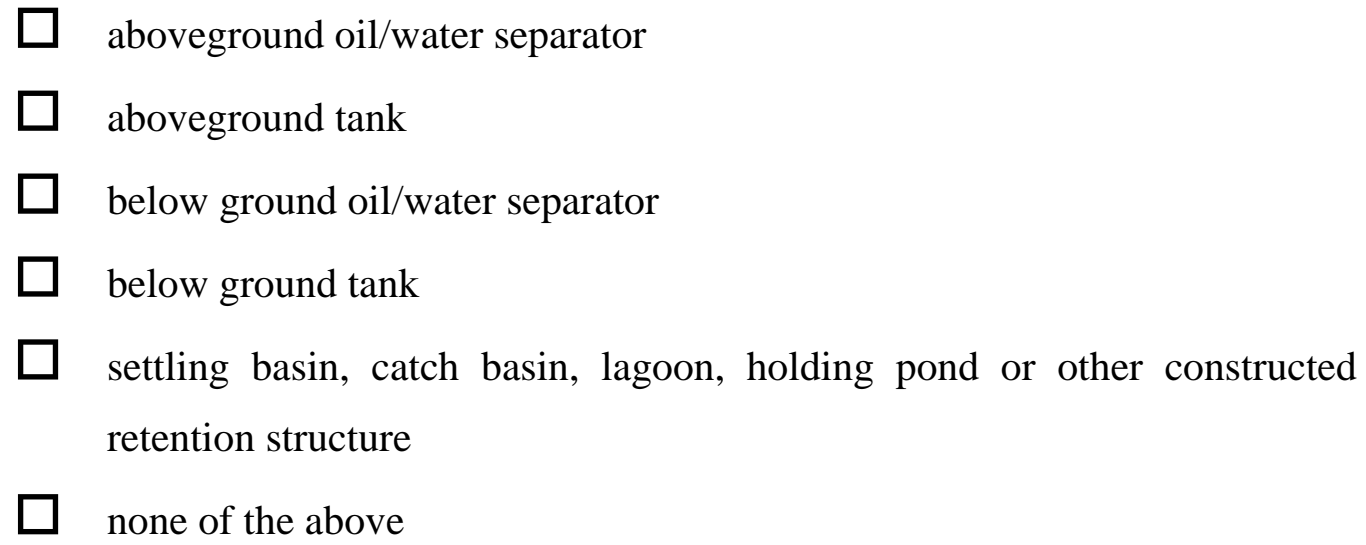

3. If liquids are captured by the devices in 2., above, are they contained until pumped and hauled to a POTW or evaporated, or do they overflow to a drainage system?

If they overflow to a drainage system, is the system above or below ground?

4. If liquids overflow to a drainage system, does the flow mix with storm water?

5. If flow does mix with storm water, see "Surface Water" section (preceding page, \#4 and \#5) for discharge.

6. If the flow doesn't mix with storm water, is it discharged to -

$\square$ subsurface soils

$\square$ on-site septic system

$\square$ drainage ditch or roadside ditch

$\square$ a nearby creek, river or other water body

$\square \quad$ lagoon or holding pond

$\square$ municipal storm sewer Owner

$\square$ municipal combined storm/sanitary sewer Owner

$\square$ municipal POTW Owner 
8. If shop floor drain and washbay effluent is discharged, other than to a municipal storm, sanitary or combined sewer, does it ultimately reach “waters of the state?” If yes, name of the nearest water body:

Activity Areas (check those that apply and describe (1) whether they are bermed to prevent storm water runoff or (2) if there are drains and their locations in the activity areas)

$\square \quad$ salt storage (pads or domes)

$\square$ salt/sand mixing

$\square \quad$ salt bed loading/wetting

$\square \quad$ salt bed washout

$\square \quad$ salt bed storage

$\square \quad$ vehicle and equipment washing (inside)

$\square \quad$ vehicle and equipment washing (outside)

$\square \quad$ asphalt equipment clean-out

$\square \quad$ herbicide mixing and tank rinsing

$\square \quad$ traffic paint mixing and transfer

$\square$ bulk tank off-loading and storage

$\square$ waste piles (e.g., ROW trash, street sweeping debris)

$\square \quad$ truck/equipment parking

$\square \quad$ truck/equipment fueling

$\square$ materials storage (210 lot, fencing, etc.)

$\square$ aggregate storage

$\square$ hot/cold patch storage

$\square$ storage of “scalp” and dirt from R/W maintenance 


\section{Assessment of Selected Structural and Non-Structural Best Management Practices (BMPs) Currently Implemented by INDOT}

\section{$\underline{\text { Introduction }}$}

The alteration of the natural environment to accommodate the transportation infrastructure, including highway, drains, bridges, maintenance facilities, toll road plazas and the like, is subject to a panoply of state and federal environmental laws and regulations. INDOT’s “Construction Activity Environmental Manual”7 provides an excellent description of these regulations and their application to construction of this infrastructure.

The inclusion by the U.S. Environmental Protection Agency of "state transportation agencies” as operators of municipal separate storm sewer systems (MS4s) attests to the potential impacts the maintenance of this infrastructure has on the environment, once constructed.

\section{$\underline{\text { BMPs Pertaining to Deicing }}$}

The most common environmental impact from highway maintenance operations results from the application of deicers to improve highway safety for motorists. The effect of such application on groundwater is described in a recent U.S. Geological Survey report; portions of the abstract of this report are included here:

The effects of highway deicer application on ground-water quality were studied at a site in northwestern Indiana using a variety of geochemical indicators. Site characteristics such as high snowfall rates; large quantities of applied deicers; presence of a high-traffic highway; a homogeneous,

\footnotetext{
${ }^{7}$ Environmental Services Section, Division of Environment, Planning and Engineering. (October 2002) http://www.in.gov/dot/pubs/manuals/cae/lindex.html)
} 
permeable, and unconfined aquifer; a shallow water table; a known groundwater-flow direction; and minimal potential for other sources of chloride and sodium to complicate source interpretation were used to select a study area where ground water was likely to be affected by deicer application.

The water-quality data indicated that chloride was the most easily traced indicator of highway deicers in ground water. Concentration ratios of chloride to iodide and chloride to bromide and Stiff diagrams of major element concentrations indicated that the principal source of chloride and sodium in ground water from the uppermost one-third to one-half of the Calumet aquifer and downgradient from US-12 was from a halite highway-deicer source.

Chloride and sodium from highway deicers were present in the aquifer throughout the year. The highest concentrations of chloride and sodium in ground water were determined in samples collected during the spring and summer from wells open to the water table within about 9 feet of the highway. Chloride concentrations in ground water that were attributable to highway deicers also were found in tested wells about 400 feet downgradient from US12 during the fall and winter and at greater depths than in wells closer to US12.

Chloride concentrations exceeded the U.S. Environmental Protection Agency's (USEPA) secondary maximum contaminant level of 250 milligrams per liter for drinking water at seven wells downgradient from the highway during late winter, spring, and summer samplings. The chloride standard was exceeded only in water from wells with total depths that are less than about 10 feet below land surface.

Automated daily measurements of specific conductance, correlated to chloride concentrations, indicated that some deicer is retained in the aquifer near the highway throughout the entire year and acts as a continuous chloride source for ground water. ${ }^{8}$

8“"Effects of Highway-Deicer Application on Ground-Water Quality in a Part of the Calumet Aquifer, Northwestern Indiana,” Lee R. Watson, et al. U.S. Geological Survey Water Resources Investigations Report 01-4260. Prepared in cooperation with the Indiana Department of Transportation. (Indianapolis, Indiana) 2002. 
INDOT officials and staff are acutely aware of the need to reduce the environmental impacts of salt storage and application and, in recent years, have implemented various structural and non-structural BMPs to reduce these impacts.

\section{$\underline{\text { Structural BMPs }}$}

- Connecting to POTW for Discharge of Vehicle Washwater and/or Installation of a Brine-making System to Reuse Washwater and Use Brine as Deicer on Highways.

It is a rare occurrence, today, that a new or replacement maintenance facility would be sited or constructed without connecting to a POTW and/or installing a brinemaking system. The 5 "new" facilities constructed in the last two years all have oil/water separators, are connected to a POTW and have brinemaking with washwater reuse. One "old" facility installed an oil/water separator and connected to a POTW. One subdistrict and unit to be constructed this year will have an oil/water separator, brinemaking with washwater reuse and be connected to a POTW. The 5 facilities to be constructed during the next two years will all have the same amenities, as described above, except for one that is too distant from a POTW to be connected, but it will have a brinemaking system. ${ }^{9}$

\section{- Prototype Salt Storage Building}

The Tipton Unit constructed a new salt storage building to replace the "old" dome structure. The roof canopy, which extends down the sides, is fiber reinforced plastic and has a 15-year warranty. If the prototype proves out, it will be replicated elsewhere, as other storage facilities are replaced. ${ }^{10}$ The facility is large enough to accommodate a

\footnotetext{
${ }^{9}$ SMCAVOY@indot.state.in.us, 26 May, 2004

${ }^{10}$ SMACVOY@indot.state.in.us, 27 Oct., 2003
} 
bucket-loader and trucks, to allow salt/sand mixing and loading operations under cover -to reduce contaminant loading of storm water and melt water.

- Installation of Brinemaking Equipment

The advantages of this technology have been well-documented by other researchers. ${ }^{11}$ This research resulted in the publication, "Innovative Environmental Management of Winter Salt Runoff Problems,” submitted to INDOT executive staff under the auspices of the Technology Deployment Work Group. ${ }^{12}$ This report is included as Appendix $\mathrm{N}$ and is also available at www.ecn.purdue.edu/CMTI/INDOT/.

To those who are not highway maintenance/operations professionals, the most obvious means of reducing the impacts of road salt on the environment is to reduce the amount of salt applied to the road. This approach, however, ignores motorists' safety and could increase the liability of the department.

INDOT operates pursuant to an unwritten, but practiced, policy identified as "continuity of service." The only reference to this practice was found in the "Total Storm Management Manual,."13 which states: “A coordinated effort must be made by all Districts and Subdistricts to provide the public with a uniform driving surface." (underline added)

\footnotetext{
${ }^{11}$ James E. Alleman, Professor, School of Civil Engineering, "Innovative Environmental Management of Winter Salt Runoff Problems at INDOT Yards,” Project SPR-2379, File No. 4-7-9, 11/15/99-3/31/04

${ }^{12}$ James E. Alleman, Professor, School of Civil Engineering, principal author; Lynn A. Corson, Ph.D., Bobby McCulloch, Ph.D., School of Civil Engineering, Barry Partridge, Ph.D., and Dennis Belter, INDOT, contributors/reviewers. August 1, 2003

${ }^{13} \mathrm{~A}$ product of the INDOT Winter Operations Team. Draft $(2 / 13 / 02)$ available at www.ecn.purdue.edu/jtrp/. Statement is on p. 95 of the draft.
} 
Road salting, especially in the karst regions of southern Indiana and on highways proximate to "sensitive" waters of the state, is a particular concern because of contaminant loading of storm water runoff.

INDOT officials recognize the problem and have implemented measures to address it, as evidenced in the following email communication excerpts from INDOT officials: ${ }^{14}$

We are making a state wide effort to increase the use of liquids for both antiicing (pre-storm) and pre-wetting (during storm) at the spinner. All new trucks purchased for snow and ice removal include pre-wet systems and have since approximately 1999. New trucks also include ground speed control which provides more accuracy and helps control salt usage.

The Vincennes District is increasing the use of salt brine for anti-icing also. This pretreatment prevents snow/ice bonding to the pavement and reduces overall salt usage.

By copy of this e-mail, I'll ask Jerry Thompson, Vincennes Operations Engineer, to have the two sensitivity sites reviewed and make every effort to incorporate the salt saving methods mentioned above. We'll let you know the results of Jerry's review.

Dennis W. Belter, Program Support Manager

Indiana Department of Transportation, Indianapolis

I think our increasing pre-wetting systems and our brine anti-icing program is evidence INDOT is in fact pursuing alternatives to dry salt and sand. I believe there is substantial evidence that the liquid pre-treatment program and the brine anti-icing program should result in less overall salt application, which is in fact the true goal of the Continuity of Service Plan. We have also shifted our focus away from sand, hopefully with the result being a more efficient removal with the potential of less salt usage. Our current plan is to grow the brine program into the Paoli Subdistrict for the winter of 2004-2005, subject to budgetary limitations.

Jerry E. Thompson, P.E., District Operations Engineer Indiana Department of Transportation, Vincennes District

\footnotetext{
${ }^{14}$ DBELTER@indot.state.in.us (December 16, 2003) and JTHOMPSON@indot.state.in.us (December 17, 2003)
} 
Approximately 120 INDOT facilities (mostly Units) store and apply salt. Six of INDOT's seven districts and over half of its 35 subdistricts made and used brine during the 2003-04 snow and ice season. The department purchased two tank trucks in 2004 and will be able to increase its practice of making brine at one location and transporting it to another for storage and application when needed. It is estimated that about 1,200 of the total 11,216 centerlane miles of highways maintained by INDOT regularly received brine application during the 2003-04 snow and ice season. ${ }^{15}$

\section{$\underline{\text { Non-Structural BMPs }}$}

- Ferric Ferrocyanide as an Anticaking Agent in Road Salt

The total cyanide limit, according to IDEM water quality standards, is 0.005 mg/L. The same limit applies to free cyanide and amenable cyanide. Total cyanide is required to be monitored by the draft Indianapolis NPDES storm water permit, the “model” for INDOT's permit. In the October 6, 2003 Federal Register, U.S. EPA published its “Final Administrative Determination Document on the Question of Whether Ferric Ferrocyanic is One of the 'Cyanides' Within the Meaning of the List of Toxic Pollutants Under the Clean Water Act” (p. 57690). Its determination is that the chemical is a toxic pollutant. A Transportation Synthesis Report, “Anti-Caking Admixtures to Road Salt,” prepared May 6, 2004 for WisDOT [Wisconsin DOT], surveyed usage of anti-caking agents and received responses from 19 state DOTs [not including Indiana]. ${ }^{16}$ The literature review accompanying the Report includes this analysis under the heading "Ferrocyanides and the Environment:"

15 DBELTER@indot.state.in.us (June 3, 2004)

${ }^{16}$ from Nina McLawhorn, Research Administrator, Wisconsin DOT [nina.mclawhorn@dot.state.wi.us], to: ‘nationalrac@yahoogroups.com.’ Subject: [nationalrac] Anticaking Survey Summary. May 18, 2004. 
At this time, sodium ferrocyanide and ferric ferrocyanide appear to be the only additives used to impede caking or crusting in stored road salt. States that deal with anti-caking agents in road salts share certain practices, according to our Internet search and survey of state winter operations. Sodium ferrocyanide-usually in the form of the product Yellow Prussiate of Soda (YPS)-seems to be the favored anti-caking agent employed around the country. The alternative to YPS sometimes employed is Prussian Blue, a ferric ferrocyanide product.

Concern over the environmental impact of ferrocyanides has been most acute in Canada. In the U.S., the FHWA has joined with the Environmental Protection Agency to designate ferric ferrocyanides as toxic, but the agencies have stopped short of banning its use in road salt, arguing that concentrations are not significant enough to cause ecological or public health concern. Unlike Canada, official U.S. concerns do not include sodium ferrocyanides, which may explain the widespread popularity of YPS over Prussian Blue. Scandinavian countries and several U.S. states concerned with the environmental impact of road salt typically focus on salinity or chloride levels in groundwater, and encourage restrained use of road salt. Restrictions on specific levels of ferrocyanides from anti-caking additives do not obtain.

While there is some disagreement on the toxicity of ferric ferrocyanide (in Prussian Blue) being matched by that of sodium ferrocyanide (in YPS), scientific studies seem to support the FHWA and EPA position that it is the former, not the latter, that poses the most risk.

Road salt itself is a potentially problematic toxin. The EPA's recent declaration of ferric ferocyanide (Prussian Blue) as a "toxic pollutant" and "hazardous substance" does not in the short-term preclude the use of it in road salts. But there is potential for future determinations of FFC-laden road salt damage that could have implications for litigation and regulation; hence, its use in highway programs should be carefully considered. See FHWA memo from Oct. 2003, and its links to official EPA pronouncements on FFC http://www.fhwa.dot.gov/environment/toxsalt.htm.

The FHWA letter referenced in the preceding quote is included, here, for information purposes. 


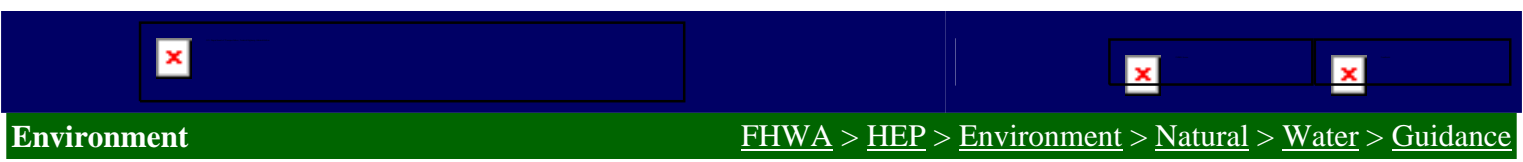

$\mathbf{x}$

Memorandum

U.S. Department of Transportation

Federal Highway Administration

Subject: INFORMATION: EPA Toxic Determination of Compound in Road Salt

Date: October 29, 2003

From: Regina S. McElroy

Director, Office of Transportation Operations

Reply to: HOTO-1

James M. Shrouds

Director, Office of Natural and Human Environment

To: Division Administrators

Resource Center Managers

Federal Lands Highway Division Engineers

To the attention of Environmental and Engineering staff.

The purpose of this message is to alert field offices that the Environmental Protection Agency (EPA) Office of Water announced a Final Administrative Determination on September 24 classifying Ferric Ferrocyanide (FFC), commonly called "Prussian Blue," as one of the "cyanides" on the Toxic Pollutant List under Section 307(a) of the Clean Water Act (CWA). The determination can be found at the following web address:

http://wwwcf.fhwa.dot.gov/exit.cfm?link=http://a257.g.akamaitech.net/7/257/2422/14mar20010800/edocket.access.gpo.gov/2003/p df/03-25272.pdf (or http://wwwcf.fhwa.dot.gov/exit.cfm?link=http://www.epa.gov/fedrgstr/EPA-WATER/2003/October/Day06/w25272.htm). Toxic Pollutants listed under CWA Section 307(a) are also "hazardous substances" under the Comprehensive Emergency Response, Compensation and Liability Act (CERCLA). The EPA's determination is based on evidence that FFC under exposure to certain environmental conditions can potentially result in the breakdown and release of free cyanide, a highly toxic chemical.

Occurrence of the precise conditions required for the breakdown of FFC are highly unlikely, and State highway agencies (SHAs) have used road salt containing FFC and a similar cyanide compound, Sodium Ferrocyanide (SFC) for decades without incident. The compounds are used as anti-caking additives.

Prior to EPA's action, the Federal Highway Administration (FHWA) raised concerns with EPA about the potential impacts on highway operations and safety. But EPA indicates that States should not have to change any current practice regarding the use of road salt containing FFC, relative to compliance with the CWA or the CERCLA. However, they should be aware that EPA in the future could establish FFC as a reportable toxic pollutant with revised regulations under the CWA and CERCLA. For this reason, we suggest that the SHAs be advised about this determination and the use of salt containing FFC.

Even though reporting is not currently required, there still could be potential liability under CERCLA for required cleanup costs associated with a cyanide contamination problem, now including FFC. But EPA has advised us that no CERCLA cleanup action due to FFC in road salt has ever been undertaken by EPA, or for that matter, by any other party. Nevertheless, we think the potential for increased litigation, adverse public reaction, and other possible liabilities due to the EPA determination remains a concern to the highway program.

The primary contact for further information on the FFC action is: Ms. Marion Kelly, EPA Office of Water, Engineering and Analysis Division, 202-566-1045. If you need further assistance, contact either: Mr. Paul Pisano in FHWA's Office of Transportation Operations, 202-366-1301; or Mr. Fred Bank in FHWA's Office of Natural and Human Environment, 202-366-5004. We have available on request background information provided by EPA in making their determination. In addition, we will continue to monitor the situation and keep you informed as appropriate.

\title{
A comprehensive review of research on the subject over the past 30 years is identified in
}

\author{
the reference cited below. ${ }^{17}$
}


The Material Safety Data Sheet (MSDS) for road salt supplied to INDOT in 2002 lists Prussian Blue and Yellow Prussiate of Soda (YPS) constituting 0.015 percent of the Safe-T-Salt product. INDOT is currently investigating the availability of alternative anticaking agents and the results of the investigation will be reviewed by the Field Maintenance and Operations Task Force.

- Operating Procedures Pertaining to Road Salt Operations

Five INDOT documents constitute the procedures and guidance pertaining to road salt operations: ${ }^{18}$

1. INDOT Salt Housekeeping Guidelines for Personnel Involved in Snow Removal, October 2, 1998 (Memorandum);

2. Operating Procedure No. 22: Snow and Ice Chemicals - Pollution Control Guidelines, August 24, 1998;

3. Operating Procedure No. 2: Snow and Ice Control, August 24, 1998 (modified March 2001);

4. INDOT - Greenfield District Liquid Chemical Application Policy, December 2001;

5. Total Storm Management Manual, Winter Operations Team, February 13, 2002 (draft).

\footnotetext{
${ }^{17}$ “Potential Water-Quality Effects from Iron Cyanide Anticaking Agents in Road Salt," Michael J. Paschka, et al. Water Environment Research, Vol. 71, No. 6., p. 1255. (Sept./Oct. 1999)

${ }^{18}$ Items 1 and 4 listed above are included in Appendix A to this report. Items 2 and 3 are included as appendices to item 5 found at www.ecn.purdue.edu/jtrp/.

Operating Procedure 22, last revised in 1998, before the December 1999

promulgation of the U.S. EPA Phase II NPDES storm water regulations, needs to be
} 
revised, again, to comport with the requirements and meaning of these and related state water quality regulations. Six changes have been recommended to the appropriate INDOT officials by the Principal Investigator as recently as March 31, 2004.

\section{$\underline{\text { Highway Maintenance BMPs }}$}

\section{- Drainage Systems}

Three INDOT Performance Standards: Inspect Minor Drainage Structures (Code 2320 PM), Cleaning Minor Drainage Structures (Code 2350) and Clean Underdrains (Code 2360 PM), establish the procedures for "crews" to maintain state highway drainage systems [there are separate procedures for side ditches]. ${ }^{19}$ These performance standards are non-structural BMPs already in place and well-practiced. According to the INDOT policy regarding maintenance responsibilities for drainage in cities and towns (see page 30), "INDOT will be responsible for maintaining the inlets, catch basins, manholes and the connecting pipes between them,” on state highways.

The Indiana Department of Environmental Management (IDEM) has advised that it intends to use the draft NPDES permit issued to the City of Indianapolis in May 2004 as the "model" for INDOT's permit. ${ }^{20}$ Two provisions of the draft permit pertaining to drainage systems would be difficult for INDOT to implement and are, probably, unnecessary for IDEM to mandate:

\footnotetext{
${ }^{19}$ INDOT Field Operations Handbook for Crew Leaders, Operations Support Division, January 2001

${ }^{20}$ This draft permit is found at www.in.gov/idem/water/npdes/public_notice/indianapolisswdraft.doc.

II.B.2.a. Set up a program to prioritize and mark storm drain inlets and catch basins within the MS4 area...to inspect and, as needed, re-establish the
} 
legibility of the wording...submit a written plan and schedule to IDEM for approval;

II.B.2.b. Set up a program to prioritize catch basin inlets within the MS4 area based on the relative volumes of trash and/or debris [collected...] a schedule of catch basin cleaning shall be established and reported to [IDEM].

According to a January 2004 survey of INDOT districts conducted by the Environmental Services Section, there are 27,769 inlets and catch basins along state highways; 27,364 of them (98.54 percent) are connected to municipal combined or separate storm sewer systems. [See Appendix O] And though the inlet data have yet to be assigned to MS4 or non-MS4 communities, it is apparent that the majority of these are in MS4 communities.

These performance standards and their corresponding performance schedule should be accepted to satisfy any proposed permit requirements for drainage systems maintenance:

- Minor drainage structures are inspected "throughout the year when weather permits a complete inspection.”

- Minor drainage structures are scheduled for cleaning "as determined by inspection [preceding] or as necessary to maintain drainage. After a period of heavy rainfall or after leaves have fallen, some structures may need attention to assure proper drainage.”

- Underdrains are scheduled for cleaning "throughout the year when weather permits complete and thorough cleaning of the drains.” 
These, as with other maintenance activities, are recorded on "Crew Day Cards" and information item 6 -- listing of location(s) for the work performed -- can, if needed, be aggregated in a computerized report to verify the work performed.

- Street Sweeping

Section II.B.2.c. of the Indianapolis draft permit requires the city to "set up a program to prioritize streets and/or street segments within the MS4 area based on the relative volumes of trash and/or debris...a schedule of street sweeping of curbed streets shall be established and reported to [IDEM]...”

INDOT districts maintain agreements with municipalities for the sweeping of state highways within their jurisdiction. The remuneration for such services is small, but, apparently, satisfactory. In September 2003, INDOT officials considered surveying its district offices to identify the municipalities with which it maintained agreements. Discussions in March 2003, preliminary to the survey, revealed that there was no single location in the districts or Indianapolis where the list of municipalities could be obtained. Further discussions in April 2004 concluded that, because these agreements benefit the state highway system, the municipalities that provide the street sweeping services should "count" the volume or weight of trash/debris in their storm water permit reports to IDEM. This conclusion, when formalized, should be communicated to municipalities by INDOT district personnel.

- Bridge Cleaning

Rule 13, section 17(b)(2)(F), prohibits "concrete or asphalt hydrodemolition waste waters from storm water runoff except under the allowance of an appropriate NPDES wastewater permit.” 
INDOT bridge cleaning, according to an INDOT official, is not hydrodemolition, it is high pressure washing, around 2,000 psi. The washwater could be filtered, if required by IDEM, before being discharged to the waters of the state. ${ }^{21}$ Filtering, however, will not remove the chlorides from the salt residue removed from the bridge.

Performance Standard 2440 PM, Flushing Bridge, applies to "cleaning of bridge seats, drain holes, expansion joints, gutter lines and truss members by flushing to remove accumulation of sand, chemicals [road salt] and debris." According to the "Equipment" listed in the Standard, a "water jet or water truck or hydroseeder" can be employed for the flushing, substantiating that the water pressure is considerably below that classified as hydrodemolition.

- Bridge Painting

The Principal Investigator monitors IDEM's monthly reports of Notices of Violation (NOVs) issued to entities alleged to have violated a state or federal environmental law. The only NOVs received by INDOT in over five years have both been issued because a bridge painting contractor did not properly containerize and/or label or transport hazardous waste paint removed from the bridge according to regulations and according to the INDOT contract based on its Standard Specification 619,

\footnotetext{
${ }^{21}$ TDUNCAN@indot.state.in.us (March 18, 2003)

which "relies heavily on the current certifications and guides provided by the Steel Structures Paint Council. SSPC.”22
} 
The Standard Specification 619 -- Painting Bridge Steel, ${ }^{23}$ in Section 619.06(a)

Pollution Control, requires the contractor to include a "containment procedure plan...in

the QCP [Quality Control Plan].” The other relevant provisions of section (a) state:

The telephone numbers for the IDEM Emergency Response Branch, local health department, and all water intake users within 150 $\mathrm{m}(500 \mathrm{ft})$ shall be provided in the QCP.

Blasting materials, scrapings, wire brushings, and paint particles shall be contained in accordance with SSPC-Guide 6 (CON), Class 3, specifically for zinc primed bridges, and SSPC-Guide 6 (CON), Class 2, for lead primed bridges.

If a spill, as defined in IDEM Regulation 327 IAC 2-6 does occur, all work shall stop and immediate action shall be taken to clean up the site. Spills of material, which enter or threaten to enter the water, shall be handled in accordance with IDEM Regulation 327 IAC 2-6. The IDEM Emergency Response Branch, the local health department, and all water intake users within $150 \mathrm{~m}(500 \mathrm{ft})$ of the bridge shall be immediately contacted and advised of the spill. Written documentation of all such contacts and actions shall be kept. All applicable Federal, State, and local rules and regulations described in 619.07(b)1 shall be observed.

No waste shall remain on the booms or on the water surface overnight. All blasting debris shall be cleaned up after each day's work. All waste material shall be properly stored at the project site to prevent loss or pollution.

Section 619.08 Surface Preparation includes performance standards; however, the Pollution Control section, which pertains to "pollution control and waste disposal of existing paint and debris," (underline added), doesn’t appear to apply to 619.08(a), Pressure Washing or 619.08(b), Solvent Cleaning and the control of any pollution

\footnotetext{
${ }^{22}$ found at www.in.gov/dot/div/contracts/standards/book/index.html

${ }^{23}$ Memorandum with attachment from Thomas L. Duncan, P.E., through Phyllis Hockett, LPG, Environmental Services Section Manager (March 27, 2002)

resulting from these surface preparation processes or the application of the new paint coating pursuant to Section 619.09, Paint Systems. The waterways under bridges and any
} 
adjoining waterbodies need to be protected from pollution that may result from surface cleaning or paint application.

The proper INDOT authority should assess whether Standard Specification 619 and its attendant provisions [cited as "SSPC Guides"] provide satisfactory protection of water quality during the performance of all activities related to "Painting Bridge Steel."

\section{Other Highway Maintenance BMPs}

Performance Standards from the INDOT Field Operations Handbook are described in Appendix $\mathrm{C}$ to the INDOT draft Storm Water permit application [included in this report as Appendix A]. The Environmental Services Section assigned storm water protection strategies to each standard [referred to as "Environmental Notes"], which are also found in Appendix C to the draft permit application. Maintenance employees will be trained on the prevention strategies.

\section{Highway Construction/Post-Construction BMPs}

\section{$\underline{\text { Introduction }}$}

Highway construction in Indiana is subject to many federal and state water quality laws and regulations and, because of unique geological features, two additional "Memoranda of Understanding," both of which mandate the installation or performance of best management practices to prevent groundwater contamination during construction or, following construction, during the performance of maintenance activities. 


\section{“Karst Agreement” [See Appendix P]}

Dated October 13, 1993 and signed by INDOT, IDEM, IDNR and the U.S. Fish and Wildlife Service, this Memorandum of Understanding delineates "guidelines for construction of transportation projects in karst regions of the state." In fact, the agreement requires BMPs during and following construction:

Section 2, para. 2: "Calculations of estimates of annual pollutant loads from the highway and drainage within the right-ofway will be made, including prior to, during and post construction estimates. The design of the treatment of the karst features will take into consideration treatments necessary to meet the standards of the monitoring and maintenance plan.”

Section 5: Drainage entering from beyond the right-of-way will be treated according to the same process as drainage generated by the project.

Section 7: Hazardous materials traps (HMT's) will be constructed at storm water outfalls and other locations that will protect karst features from spill contamination.

Section 8: Indiana Department of Transportation agrees to develop a monitoring and maintenance plan for the affected karst features. The establishment of water quality and a point at which a standard is established for remediation will be a part of each monitoring plan.

Section 9: A low salt, and no spray strategy will be developed for each future project. A signing [signage] strategy for these items will also be developed for each project.

Section 11: The erosion control plan must be available at the project administrator's office. An emergency response plan will be made a part of the contract documents. In addition, the contract documents will contain a strategy for signing to alert the public to the fact that all types of spills are potentially hazardous to the karst environment.

The karst agreement and INDOT's intent to adhere to its provisions resulted,

ultimately, in the installation of two types of structural BMPs along SR 37 between Bedford and Mitchell: peat filters and two chamber detention ponds.

No policies, procedures or schedule pertaining to the maintenance of either type of structure has been located. An INDOT official reported that, as to the ponds, a staff 
person instrumental in the design of the ponds "said that they did not plan on maintaining them. Once the vegetation was established in the second chamber, the filter medium was no longer needed. The structures then performed as only detention ponds with vegetative filtration. The upper chamber, however, still needs [to be] cleaned of floatables." ${ }^{24}$

According to staff in the Vincennes District, there are no formal procedures to inspect or clean the ponds, nor has any training been provided concerning maintenance, if any is required.

One conversation conveyed that peat filters used to be changed occasionally years ago, but the location of all of them is not known by some of the newer employees.

BMP selection criteria are currently being researched and preferred types of structural BMPs will be recommended. ${ }^{25}$ Perhaps, double-chamber detention ponds can be installed elsewhere in the state; however, without a determination of their efficiency and an estimate of their maintenance frequency and costs, such a recommendation may not be advised. INDOT should assess these structures, adopt formal procedures and a schedule for inspection and maintenance and determine if these BMPs can and should be replicated elsewhere.

\footnotetext{
24 TDUNCAN@indot.state.in.us (August 28, 2003)

25“Assessment and Selection of Storm Water Best Management Practices for Highway Construction, Retrofitting and Maintenance,” JTRP Project No. C-36-78V, File No. 4-722, SPR-2853, 1/1/04-6/30/06
} 


\section{Sole Source Aquifer Memorandum of Understanding}

The April 1989 Memorandum of Understanding between the U.S. EPA Region 5 and Federal Highway Administration Region 5, Indiana Division "is to ensure that Federal-aid highway projects located in designated sole source aquifers are designed, constructed and maintained in a manner that will prevent the introduction of contaminants into the aquifer in quantities that may create a significant hazard to public health. All proposed projects located [wholly or in part] within the limits of the St. Joseph Aquifer System must comply with the requirements of the subject MOU...”26

The provisions of the agreement pertain to:

(1) construction of additional through-traffic lanes or interchanges on existing roadways;

(2) construction of a two or more lane highway on new alignment;

(3) construction of rest areas on scenic overlooks with on-site sewerage disposal facilities;

(4) any project involving a new or existing well;

(5) any other project that FHWA, in consultation with EPA, believes may have a potential to affect the designated aquifer through its recharge zone so as to create a significant hazard to public health.

According to the June 23, 1988 Federal Register publication of EPA's “Notice of Final Determination” regarding the “St. Joseph Aquifer System, Indiana, Sole Source

\footnotetext{
${ }^{26}$ Cover letter to Mrs. Christine W. Letts, Director, Indiana Department of Highways, Indianapolis, Indiana from Arthur A. Fendrick, Division Administrator, May 9, 1989.
} 
Aquifer Petition,” the aquifer, then, served as the sole or principal source of drinking water for approximately 290,000 residents of Elkhart, St. Joseph, LaGrange, Noble and Kosciusko Counties. EPA's "basis for determination" refers to "over 44 cases of ground water contamination in Elkhart County, alone" and that potential sources for contamination include, among five named sources, “(E) salting of roads for ice control." 27 EPA has authority to "review projects that may introduce excessive amounts of any EPA Priority Pollutants and the following contaminants into a sole source aquifer:

Chlorides (road salting, salt storage, etc.)

Bacteria (septic drainfields, land application, etc.)

Nitrates (feedlots, fertilizer storage and application, etc.)

Pesticides normally used for landscape maintenance.”

There are no sensitivity level 1,2 or 3 highways in the area served by the sole source aquifer. However, there are 6 maintenance facility locations: Elkhart Maintenance and Toll Road District (Toll Roll District), South Bend Unit and Mishawaka Unit (LaPorte District) and Goshen Sub and Elkhart Sub and Unit (Fort Wayne District). These facilities will be prioritized for a site visit during the SPR 2854 study, "Deriving the Cost Impacts of Indiana's Storm Water Rule 13 on INDOT Maintenance Facility Operations.”

It is assumed that the Memorandum of Understanding remains in effect and that highway construction and maintenance plans, since 1988, have been specified accordingly. The department should assess whether these plans have incorporated structural or non-structural BMPs as a condition of compliance with the memorandum.

${ }^{27}$ Federal Register, Vol. 53, No. 121, Thursday, June 23, 1988. p. 23683 


\section{Constructed Wetlands}

The only other type of structural BMP in the state highway system -- and there is only one example of this type -- is the constructed wetland located on the south side of the Toll Road at the Grant Street exit (14A), north of the old toll plaza. It was part of the \$2.5 million plaza improvement project completed in the fall of 1999 . The funding was from an EPA grant to IDEM and the project was administered by the INDOT Toll Road District. The project was initiated because of excessive silt and sand from vehicles exiting the steel mills and an aggregate mining area accumulating on the roadway and entering the Calumet River in a storm water runoff. It is estimated to drain an area of toll road and ramps comprising approximately 50 acres. Apparently, little if any maintenance has needed to be performed since it was constructed. ${ }^{28}$

There is one other wetland, a 7.5 acre tract, constructed in late 2003 along I-65 and SR 62 in Clarksville. It has a small filtering capacity for storm water runoff from about one-quarter mile of I-65 southbound, but it was constructed to replace wetlands destroyed in the "Revive 65" highway improvement project. Its primary function, then, is mitigation."29

\footnotetext{
${ }^{28}$ dwarner@toll.indot.state.in.us (August 21 and 27, 2003)

29 TDUNCAN@indot.state.in.us (January 27, 2004)
} 


\section{APPENDICES \\ TABLE OF CONTENTS}

$\begin{array}{lll}\text { APPENDIX A INDOT’s Permit Application } & 77\end{array}$

$\begin{array}{lll}\text { APPENDIX B } & \text { MS4 Designated Entity Listing }\end{array}$

APPENDIX C INDOT Facility Latitude/Longitude Coordinates 133

APPENDIX D INDOT Facilities, by District, Within and Outside

MS4 Areas 139

APPENDIX E CD-ROM State Roads in MS4 Areas

State_Roads_Rule13_listing_2004.xls (June 6, 2004) 143

APPENDIX F $\quad$ Directory of Indiana POTWs Used to Identify MS4

Communities With and Without Combined Systems 144

APPENDIX G Results of Survey of Indiana's 106 Combined

Sanitary/Storm Sewer POTWs 166

APPENDIX H CD-ROM Inventory of Bridges State Highway

System of Indiana (January 9, 2002; 1.02) 172

APPENDIX I Description of GIS Layers for Identifying Sensitive

Water Areas 173

$\begin{array}{lll}\text { APPENDIX J Priority Rivers and Streams Segments } & 182\end{array}$

APPENDIX K CD-ROM MS4 Miles by District and by Sensitivity

Code (July 19, 2004)

APPENDIX L CD-ROM Bridge and Sample Points for Priority

1, 2 and 3 Waters, All Districts (revised 4/7/04)

APPENDIX M CD-ROM Location and Results (2003) for INDOT

SWM Sample Sites, and description of selected (10

mile radius) sample sites from IDEM \& USGS (4/15/04) 191

APPENDIX N Draft of "Innovative Environmental Management of

Winter Salt Runoff Problems” 192

$\begin{array}{lll}\text { APPENDIX O } & \text { BMP Inlets }\end{array}$

$\begin{array}{lll}\text { APPENDIX P } & \text { Karst Agreement }\end{array}$ 


\section{APPENDIX A}

(Appendix A to this Permit Application is identical to Appendix K of the study report and, therefore, is not included in this appendix) 


\title{
INDIANA DEPARTMENT OF TRANSPORTATION
}

\author{
National Pollutant Discharge Elimination System (NPDES) \\ Individual Storm Water Discharge Permit \\ September 24, 2003
}

\section{INTRODUCTION}

The Indiana Department of Transportation (INDOT) is responsible for approximately 11,300 center line miles (28,500 total lane miles) of highways and interstates in Indiana, as well as 5,519 bridges. These highways and bridges are located in all ninety-two (92) counties and all designated Municipal Separate Storm Sewer System (MS4's) in Indiana. To avoid being a copermittee with hundreds of MS4's, INDOT proposes permit action for an individual storm water discharge permit, in accordance with 327 IAC 5-4-6. INDOT's NPDES Individual Storm Water Discharge Permit will regulate and allow the discharge of storm water runoff from those State Highways, Interstates, and bridges, as well as Operation/Maintenance facilities that are located within the limits of an MS4 or an Urbanized Area (UA), including the Toll Road (I-80/90). An MS4 is defined in 327 IAC 15-13-3 MS4 area designation criteria, as a Municipal Separate Storm Sewer System with a conveyance serving a municipal population of seven thousand $(7,000)$ or more. An Urbanized Area is also defined in 327 IAC 15-13-3, as an area with a population density equal to, or greater than five hundred (500) people per square mile, that is located outside an MS4 jurisdictional limit. All demographics are referenced to the 2000 Census data. All INDOT Highways, Interstates, bridges, as well as Operation/Maintenance facilities that are located within an MS4's jurisdiction shall meet the minimum requirement under those MS4's NPDES Storm Water permit; however, the INDOT highways and facilities will not be subject to any unreasonable or inexplicable monetary assessments, taxes, or fees, imposed by the MS4's.

\section{INITIAL CHARACTERIZATION and PRIORITIZATION Of RECEIVING WATERS}

IDEM has required that INDOT develop an initial characterization of the receiving waters, waters of the State, that INDOT right-of-way or facilities will have potential to impact. Since INDOT highways drain to virtually every stream or river in the State, it will be impossible to develop an initial characterization of every one of the waters of the State. INDOT has initiated a Joint Transportation Research Project (JTRP), with principal investigator Lynn Corson, Ph.D. Director of Indiana Clean Manufacturing Technology and Safe Materials Institute, Purdue University, School of Civil Engineering. The primary goal of the JTRP was to prioritize the more "sensitive waters" that INDOT may impact. IDEM has established four (4) criteria for "sensitive waters":

1. Providing habitat for threatened or endangered species.

2. Usage as a public surface water supply intake.

3. Relevant community value ("full-body contact recreation").

4. Exceptional use classification, outstanding State resource water classification, or "high quality waters". 


\section{INDOT Priority System}

Indiana Natural Resources Commission, in 1993, promulgated its "Outstanding Rivers List for Indiana". This is a list of Indiana rivers and streams that have particular environmental or aesthetic interest. The INDOT priority system identified four (4) levels of priority and the list of priority 1-3 (2,557) is included in APPENDIX A. The JTRP study identified 18,653 sites where the following INDOT priority 1-4 "sensitive waters" criteria was used:

- INDOT facilities and highways within a Rule 13 designated MS4 area

- INDOT facilities and highways within a Rule 13 designated Urbanized Area

- INDOT facilities not connected to a Public Owned (Operated) Treatment Works (POTW)

- INDOT facilities and highways within a karst area

- INDOT facilities and highways within 3,000 feet of a community public well (well head protection area)

- INDOT facilities and highways within 1,000 feet, 3,000 feet, or one (1) mile of a public surface water intake

- INDOT facilities and highways within one (1) mile of high quality and exceptional use waters

- INDOT facilities and highways within one (1) mile of federal, state, county, municipal or township recreation facility having a lake, pond, river, or stream

- INDOT facilities and highways within 3,000 feet of groundwater that is highly vulnerable to contamination

- INDOT facilities and highways within 3,000 feet of a natural area containing endangered, threatened, or rare species

- INDOT facilities and highways within one (1) mile of the "best remaining example of a natural wetland community," as defined by IDNR

\section{INDOT Initial Characterization}

Initial characterization will be developed by testing selected receiving waters, based on priority. Periodic follow-up sampling and testing will be accomplished for annual reporting. A 6920 Sonde multiparameter portable testing probe manufactured and distributed by YSI Environmental was used to test the priority waters for initial characterization. Subsequent laboratory tests will be run to correlate pollutants of concern. The YSI Probe tested the following parameters:

- Conductivity $(\mu \mathrm{S} / \mathrm{cm})$ (micro-mhos/centimeter or micro-Siemens/centimeter)

- Dissolved Oxygen (DO) (mg/L) (milligram/Liter)

- Chloride (mg/L) (milligram/Liter)

- $\mathrm{pH}(\%)$

- Oxygen Reduction Potential (ORP) (mV) (millivolts)

- Turbidity (NTU) (nephelometric turbidity units)

- Temperature $\left({ }^{\circ} \mathrm{C}\right)$ (Degree Celsius)

The initial testing of all Priority 1 waters was conducted between July $14^{\text {th }}$, and August $12^{\text {th }}$, 2003. The latitude and longitude coordinates, to the nearest 0.001 of a minute, were also obtained at each test site using a portable 12 channel GPS devise called etrex, manufactured by Garmin. The results of the initial testing are included in APPENDIX B. 


\section{STORM WATER QUALITY MANAGEMENT PLAN}

The Storm Water Quality Management Plan (SWQMP) required by the proposed permit is designed to produce the information necessary to effectively manage a statewide storm water conveyance system on urban highways and meet the requirements of the federal storm water regulations. The proposed permit requires that the applicant reduces pollutants to the maximum extent practicable and completes and implements the SWQMP. The SWQMP includes continued implementation through annual reports. The SWQMP will include the following components:

Public Education and Outreach Program

Public Participation and Involvement Program (Public input into INDOT's SWQMP)

Illicit Discharge Detection and Elimination Program

Construction Site Storm Water Runoff Control (Rule 5, 327 IAC 15-5-1)

Post Construction Storm Water Management

Pollution Prevention at INDOT Operation and Maintenance Facilities located within an

MS4 and for Road-Side Maintenance located within an MS4 (Good Housekeeping)

\section{PUBLIC EDUCATION AND OUTREACH}

\section{A. Benefits of INDOT's Public Education and Outreach Program}

An informed and knowledgeable public is critical to the success of a storm water management program. Without public knowledge of water quality problems caused by runoff from highways, it is difficult to obtain public support for statewide storm water quality programs. As with all of the six minimum control measures, the goal of this measure is to improve the chemical, physical and biological quality of the waters of the State by reducing the degradation from highway runoff. In order to achieve this water quality benefit, Public Education programs should be targeted to these outcomes:

- Improve understanding of the reasons why storm water quality programs must exist. Public understanding of the statewide impacts to waters of the State are important when INDOT must impose added requirements to permits, fees, or contracts, and when seeking volunteers to help implement some programs.

- Greater compliance with the program as the public becomes aware of the personal responsibilities expected of them and others, including the individual actions they can take to protect and improve the quality of waters in their area of the State.

\section{B. Program Requirements}

To paraphrase the Rule 13 regulations (327 IAC 15-13-12) into requirements that may be used for an individual NPDES permit for INDOT:

INDOT shall develop a SWQMP that includes methods and measurable goals that will be used to inform the public, construction site personnel, and INDOT 
employees about the impacts polluted storm water runoff can have on water quality and ways they can minimize their impact on storm water quality.

INDOT shall utilize existing programs and outreach materials to meet this measure.

INDOT shall complete and submit a certification form to the Indiana Department of Environmental Management (department) once the program has been developed and implemented, or three hundred sixty-five (365) days from the date of permit issuance, whichever is earlier. At a minimum, every five (5) years the program shall be reviewed for adequacy and accuracy and updated as necessary.

INDOT shall develop measurable goals for this measure.

\section{Guidelines for Developing and Implementing This Measure}

To satisfy this minimum control measure, INDOT will:

- Implement a public education program to distribute educational materials to the citizens of Indiana, or conduct equivalent outreach activities about the impacts of storm water discharges and the steps that can be taken to reduce storm water pollution.

- Target construction contractors and aggregate suppliers with information materials appropriate to them on the potential storm water impacts of improper waste disposal and illegal discharges from their operations and construction sites.

- Determine the appropriate best management practices (BMP's), in this case informational and educational methods to be used, and measurable goals for this minimum control measure.

There are three (3) main action areas of importance in implementing a successful public education and outreach program.

1. Forming Partnerships

Currently INDOT sponsors the "Adopt-A-Highway Program", wherein community-based organizations, corporations, schools, clubs, fraternities, sororities, and associations can accept the responsibility of keeping a segment of State Highway clean and neat in return for placing an informational sign stating that their organization is responsible for this endeavor. The trash and debris collected from this activity will be weighed for annual reporting and is, and will continue to be, properly disposed of. This program is quite successful and will be continued and expanded wherever possible.

Currently INDOT conducts an annual program called "Trash-Bash", wherein INDOT employees (some volunteering outside their everyday tasks), correctional detainees (Department of Corrections), and Adopt-A-Highway participants pickup trash on interstate and state routes that are to be mowed. This activity is coordinated every year just before the mowing season begins. The trash and debris collected from this activity will be weighed for annual reporting and is, and will continue to be, properly disposed of. 
Currently INDOT has a Partnering Program with contractors that perform construction on INDOT projects. INDOT has developed a Partnering Handbook for these construction projects. The first step in a formalized partnering process is an all day partnering workshop in which team members:

- establish a common mission statement, team objectives, and guidelines;

- define issue resolution and problem escalation processes specific to that team; and

- create an evaluation process to ensure continuous improvement.

The development of a Team Charter during the workshop enables all parties to focus on cooperation, communication, and commitment. The Charter is a listing of mutually agreeable goals of all stakeholders. While the contract itself defines the responsibilities of each party, the Charter provides a document in which all parties can share their goals for the contract. The Charter is not a legal document. Rather, it is a personal commitment of the participants that they will work for the success of the project. A storm water quality management component can be easily incorporated into the workshop. This continuous Partnering Program will be an asset to keeping construction sites clean and preventing excess, sediment laden, runoff from entering streams, through a cooperative effort among all stakeholders at the site.

Currently INDOT conducts pre-construction conferences for all of its projects. These conferences are an in-depth discussion of the contract requirements between INDOT and the Contractor, including any sub-contractors. A storm water quality management component can be easily incorporated into a pre-construction conference.

Currently INDOT collects the carcasses of animals that are killed on highways. These small and large animals are reported on a form and the disposition depends on the location, INDOT treats the animal carcass in one of the following five (5) ways:

(1) Processed for meat or pet food

(2) Contract pick-up

(3) Composted at INDOT facility

(4) Incinerated at INDOT facility

(5) Buried on-site or off-site

INDOT will strive to enter into partnerships with other governmental agencies and entities to fulfill the requirements of this minimum control measure. The Indiana Department of Natural Resources has programs like "Riverwatch" and Project "Wet" and "Indiana Storm Drain Stenciling Project" that INDOT can partner with and support in local areas where highways will have greater impact to waters of the State. 


\section{Using Educational Materials and Strategies}

Brochures and other forms of literature on Highway Storm Drainage will be developed to inform the public how INDOT is taking steps to improve the water quality of the storm water runoff from highways. This information will also include education of how people can contribute to the efforts of improving the storm water quality. Brochures and fact sheets will be distributed annually at the State Fair, possibly with vehicle registration and driver license receipts at the Bureau of Motor Vehicles (BMV), and at the Interstate Rest Areas and Welcome Centers. An informational and educational message will be printed on the State Highway Map that INDOT annually updates and distributes statewide.

INDOT website will be used to broadcast the brochure and any storm water quality information to internet users.

Roadway and Rest Area signage will be increased to inform the traveling public of environmentally sensitive areas and areas where storm water runoff is being improved. Rest Areas will have signs that say: No RV Waste Dumping, No Dumping of Vehicle Fluids, Spill Reporting Phone Number...(both INDOT and IDEM), and Pet Area (at least 150 feet from stream). Roadway signs will say; No Spray Zone, Low Salt Zone, Spill Reporting Phone Number...(both INDOT and IDEM), Environmentally Sensitive Area Any Spills In Area Are Potentially Hazardous. Storm drain marking at inlets to sensitive waters can be installed as a part of INDOT construction projects.

\section{Reaching a Broad and Diverse Audience}

As tax monies become available, radio, television, and billboard advertisements may be incorporated into INDOT's Public Outreach program. Multilingual printed posters and brochures will be used to reach audiences less likely to read standard materials. INDOT materials will also be targeted toward the motoring public with information that will encourage people to keep their vehicles well maintained so as not to leak or drip oil and gas onto the highways, where these materials will be washed into the streams as pollutants.

\section{Measurable Goals}

INDOT will conduct a survey at the State Fair in all five (5) years of the permit to ascertain how many people have gained knowledge about storm water runoff from highways over the years from INDOT's public education program.

The following are the measurable goals for INDOT's Public Education and Outreach Program for the initial five (5) year permit period. 


\begin{tabular}{|c|c|}
\hline Target Date & Activity \\
\hline $\begin{array}{l}\text { Year } 1 \\
\text { November 1, } 2003 \text { to } \\
\text { October } 31,2004\end{array}$ & $\begin{array}{l}\text { - Conduct initial survey at State Fair, August } 2004 \text {. } \\
\text { - Create information on INDOT website relative to storm } \\
\text { water runoff from highways by July } 2004 \text {. } \\
\text { - Develop brochures to be placed at Rest Areas and } \\
\text { distribute at the State Fair, August } 2004 \text {. } \\
\text { - Develop message for the State Map to be published } \\
\text { June, 2004, distribute maps at State Fair August } 2004 \\
\text { - Develop spill clean-up materials (kits) and information } \\
\text { to be installed in Year } 2 \text { at Rest Areas, Weigh Stations, } \\
\text { and Welcome Centers. }\end{array}$ \\
\hline $\begin{array}{l}\text { Year } 2 \\
\text { November 1, } 2004 \text { to } \\
\text { October } 31,2005\end{array}$ & $\begin{array}{l}\text { - Distribute brochures at Rest Areas and Welcome Centers } \\
\text { by August } 2005 \text {. } \\
\text { - Conduct follow-up survey at State Fair, August } 2005 \text {. } \\
\text { - Distribute brochures and maps at State Fair, August } \\
2005 \text {. } \\
\text { - Develop signs for Rest Areas and Roadways by October } \\
\text { 31,2005. } \\
\text { - Deploy spill clean-up kits and information at Rest Areas, } \\
\text { Weigh Stations and Welcome Centers by August } 2005 \text {. }\end{array}$ \\
\hline $\begin{array}{l}\text { Year } 3 \\
\text { November 1, } 2005 \text { to } \\
\text { October } 31,2006\end{array}$ & $\begin{array}{l}\text { - Develop target audience-based programs with } \\
\text { construction contractors and aggregate suppliers to } \\
\text { introduce at Purdue Road School in March } 2007 . \\
\text { - Develop a partnership with IDNR Programs, } \\
\text { Riverwatch, Project WET, and Stenciling Program by } \\
\text { October 31, 2006. } \\
\text { - Conduct follow-up survey at State Fair, August } 2006 \text {. } \\
\text { - Maintain spill clean-up kits and information. } \\
\text { - Begin installing signs at Rest Areas and on Roadways, } \\
\text { April 2006. }\end{array}$ \\
\hline $\begin{array}{l}\text { Year } 4 \\
\text { November 1, } 2006 \text { to } \\
\text { October } 31,2007\end{array}$ & $\begin{array}{l}\text { - Revise brochure in multiple languages to be distributed } \\
\text { at select Rest Areas in Year } 5 \text {. } \\
\text { - Conduct follow-up survey at State Fair, August } 2007 . \\
\text { - Maintain spill clean-up kits and information. } \\
\text { - Continue installing signs at Rest Areas and on } \\
\text { Roadways throughout } 2007 \text {. } \\
\text { - Continue developing and expanding the partnership with } \\
\text { IDNR Programs in 2007. }\end{array}$ \\
\hline $\begin{array}{l}\text { Year } 5 \\
\text { November 1, } 2007 \text { to } \\
\text { October } 31,2008\end{array}$ & $\begin{array}{l}\text { - Continue and expand partnership with IDNR Programs } \\
\text { in } 2008 . \\
\text { - Conduct follow-up survey at State Fair, August } 2008 \text {. } \\
\text { - Distribute revised brochure in multiple languages at } \\
\text { State Fair, August } 2008 \text {. } \\
\text { - Conduct target audience-based training program with } \\
\text { construction contractors and aggregate suppliers } \\
\text { February 2008. } \\
\text { - Maintain spill clean-up kits and information. }\end{array}$ \\
\hline
\end{tabular}




\section{PUBLIC PARTICIPATION AND INVOLVEMENT}

\section{A. Benefits of INDOT's Public Participation and Involvement Program}

The Public can provide valuable input and assistance to INDOT's storm water management program. Since it is the activities of the public within the State that produce pointless personal pollution, and the public that pays taxes to fund the INDOT functions, it is imperative that the public be empowered to play an active role in both the development and implementation of the program. An active and involved community is critical to the success of a storm water management program to allow for:

- Broader public support, since citizens who participate in the development and decision making process are partially responsible for the program and are more likely to take an active role in its implementation;

- A broader base of expertise and economic benefits, since the citizens of the State can be a valuable, free, intellectual resource; and

- A conduit to other programs, as citizens involved in the storm water program development process provide important cross-connection and relationships with other municipal and government agency programs. This benefit is particularly valuable when trying to implement a storm water program integrated on a watershed basis.

\section{B. Program Requirements}

To paraphrase the Rule 13 regulations (327 IAC 15-13-13) into requirements that may be used for an individual NPDES permit for INDOT:

INDOT shall develop an SWQMP that includes provisions to allow opportunities for the public to participate in the storm water management program development and implementation.

INDOT shall comply with applicable public notice requirements.

INDOT shall complete and submit a certification form to the department once the program has been developed and implemented, or three hundred sixty-five (365) days from the date of permit issuance, whichever is earlier. At a minimum, every five (5) years the program shall be reviewed for adequacy and accuracy and updated as necessary.

INDOT shall develop measurable goals for this measure.

\section{Guidelines for Developing and Implementing This Measure}

To satisfy this minimum control measure, INDOT will:

- Comply with applicable State (Indiana Code, IC 4-22-3, Open Public Hearings) and local public notice requirements using an effective mechanism for reaching the public; 
- Determine the appropriate BMP's and measurable goals for this minimum control measure. Possible implementation approaches, BMP's (i.e., the program actions and activities), and measurable goals are described below.

INDOT will, to the greatest extent possible, include the public in developing, implementing, and reviewing each minimum measure of their storm water management programs. The public participation process will make every effort to reach out and engage all economic and ethnic issues. INDOT recognizes that there are challenges associated with public involvement. Nevertheless, INDOT strongly believes that these challenges can be addressed through an aggressive and inclusive program. Challenges and example practices that can help ensure successful participation are discussed below.

Currently INDOT involves the public in the planning process for transportation projects funded with Federal Highway Administration (FHWA) dollars. Annually, INDOT meets with citizens across the State to discuss transportation issues, programmed projects and to provide time for public involvement in development of their transportation programs. In August every year, six meetings are held across the State to provide this information and collect input on the draft Indiana Statewide Transportation Improvement Program (INSTIP).

Current INDOT holds numerous public hearings on individual projects through out the State. These public hearings are in accordance with the National Environmental Policy Act of 1969 (NEPA) and the opportunity for open public comment is in accordance with Indiana Code, IC 4-22-3, Open Public Hearings. These hearings are required on all federally funded highway projects that require environmental review and appropriate environmental documents.

Storm Water Quality Management Plan Public Hearings/Meetings will be held at six sites across the State to provide Highway Storm Water Runoff information and collect input for the Plan. The opportunity for open public comment will be in accordance with Indiana Code, IC 4-22-3. Informational materials relative to these hearings will be published in different languages appropriate for the area of the State in which they are being held.

Currently INDOT often relies on advertising in local newspapers to announce the above mentioned planning meetings and public hearings. INDOT also lists the scheduled hearings on the internet as part of the on-line calendar. Since there may be large sectors of the population who do not read the local press or use the internet, the audience reached can be limited. Therefore, alternative advertising methods will be used whenever possible, including radio or television spots (public service announcements), postings at bus or light rail stops (Mass Transit Terminals), announcements in neighborhood newspapers/newsletters, announcements at civic organization meetings, school functions, distribution of flyers, all including multilingual announcements where appropriate.

\section{Measurable Goals}

Measurable goals, which are required for each minimum control measure, are intended to gauge permit compliance and program effectiveness. At a minimum, the measurable goal for this program is to provide adequate public notice of all public hearings and planning 
meetings, published in a community publication or newspaper of general circulation, when implementing the storm water management programs required under the permit.

The following are the measurable goals for INDOT's Public Participation and Involvement Program for the initial five (5) year permit period.

\begin{tabular}{|c|c|}
\hline Target Date & Activity \\
\hline $\begin{array}{l}\text { Year } 1 \\
\text { November } 1,2003 \text { to } \\
\text { October } 31,2004\end{array}$ & $\begin{array}{l}\text { Develop and conduct six State-wide Public } \\
\text { Hearing/Meetings by November } 30,2003 \\
\text { Notices will be published in several print media and } \\
\text { bilingual flyers, including internet postings, in } \\
\text { accordance with Indiana Code, IC 4-22-3 } \\
\text { - Final recommendations as a result of the public } \\
\text { comments will be published by March } 1,2004 \text {. }\end{array}$ \\
\hline $\begin{array}{l}\text { Year } 2 \\
\text { November } 1,2004 \text { to } \\
\text { October } 31,2005 \\
\end{array}$ & $\begin{array}{l}\text { - Programs will also be posted on the internet "List } \\
\text { Service" by March 1, 2004. }\end{array}$ \\
\hline $\begin{array}{l}\text { Year } 3 \\
\text { November } 1,2005 \text { to } \\
\text { October } 31,2006\end{array}$ & $\begin{array}{l}\text { Nothing required, as the Storm Water Quality } \\
\text { Management Plan has been adopted and implemented. }\end{array}$ \\
\hline $\begin{array}{l}\text { Year } 4 \\
\text { November } 1,2006 \text { to } \\
\text { October } 31,2007\end{array}$ & $\begin{array}{l}\text { - Nothing required, as the Storm Water Quality } \\
\text { Management Plan has been adopted and implemented. }\end{array}$ \\
\hline $\begin{array}{l}\text { Year } \mathbf{5} \\
\text { November 1, } 2007 \text { to } \\
\text { October } 31,2008\end{array}$ & $\begin{array}{l}\text { Prepare for renewal of NPDES Permit by conducting six } \\
\text { State-wide Public Hearing/Meetings before October } 1 \text {, } \\
2008 \\
\text { Notices will be published in several print media and } \\
\text { bilingual flyers, including internet postings, in } \\
\text { accordance with Indiana Code, IC } 4-22-3 \\
\text { Final recommendations as a result of the public } \\
\text { comments will be published by November } 1,2008 \text {. }\end{array}$ \\
\hline
\end{tabular}

\section{ILLICIT DISCHARGE DETECTION AND ELIMINATION PROGRAM}

An illicit discharge is defined as any discharge to INDOT right-of-way that has not been authorized by INDOT licensure. Illicit discharges enter the system through direct means of outlet pipes either mistakenly or deliberately discharged onto INDOT right-of-way or connected to an INDOT storm drainage system. Illicit discharges can also enter the system indirectly/inadvertently from cracked sanitary systems, spills on the highway, or spills collected by drain outlets and conveyed to INDOT right-of-way.

Illicit discharges may be continuous or intermittent. Intermittent discharges usually occur when carried by a storm event, while continuous illicit discharges will often flow during dry weather. 


\section{A. Benefits of INDOT's Illicit Discharge Detection and Elimination Program}

Illicit discharges can result in untreated discharges that contribute high levels of pollutants, including heavy metals, toxins, oil and grease, solvents, nutrients, viruses, and bacteria, to receiving waterbodies. Pollutant levels from these illicit discharges have been shown in EPA studies to be high enough to significantly degrade receiving water quality and threaten aquatic life, wildlife, and human health. Reduction of illicit discharges helps to maintain the integrity of the highway drainage system and minimizes the amount of pollutants that are discharged to waters of the State.

\section{B. Program Requirements}

To paraphrase the Rule 13 regulations (327 IAC 15-13-14) into requirements that may be used for an individual NPDES permit for INDOT:

INDOT shall develop an SWQMP that includes a commitment to develop and implement a strategy to detect and eliminate illicit discharges to INDOT right-ofway.

INDOT shall locate and identify the outfalls in INDOT's priority system that are discharging to sensitive waters of the State.

INDOT shall develop a regulatory mechanism that will prohibit illicit discharges onto right-of-way, and establish appropriate enforcement procedures and actions.

INDOT shall complete and submit a certification form to the department once the regulatory mechanism has been developed and implemented, or three hundred sixty-five (365) days from the date of permit issuance, whichever is earlier. At a minimum, every five (5) years the program shall be reviewed for adequacy and accuracy and updated as necessary.

INDOT shall educate public employees, businesses, and the general public about the hazards associated with illicit discharges and improper disposal of waste.

INDOT shall develop measurable goals for this measure.

\section{Guidelines for Developing and Implementing This Measure}

This section identifies those provisions that are required under the regulations. Although the extent of the efforts INDOT can dedicate to a storm water management program are dependent on available resources, staff, and degree and character of the illicit discharges, the following three (3) minimum requirements must be satisfied:

- Development of an Illicit Discharge Detection and Reporting System

- Development of a Storm Water Control Policy (Discharge to ROW License)

- Storm Water Drainage Maps

1. Illicit Discharge Detection and Reporting System

INDOT shall train Operations and Maintenance workers to recognize and report all illicit discharges to the right-of-way that are detected during routine maintenance operations. The procedures for reporting detected illicit discharges will be referred to as INDOT's Enforcement Response Plan for Illicit Discharges to the right-of-way. INDOT does not have a mechanism to take 
enforcement action against violators who discharge illicitly onto the right-of-way. INDOT will report illicit discharge violators to the proper authority, to IDEM or to the County Health Department. A tagging/marking system shall be developed to readily (physically) identify those discharge points that are authorized by INDOT, all others will be considered illicit or illegal.

\section{Storm Water Control Policy}

In the past INDOT has agreed to allow adjacent developments to discharge storm water onto the right-of-way if the pre-development quantity of runoff was not exceeded after construction was completed. The NPDES rule requires that the quality of runoff be characterized. INDOT will develop a Discharge to Right-ofway License for developers and property owners that wish to discharge their storm water to INDOT right-of-way. This will be a five (5) year renewable license; thus, allowing INDOT the opportunity to review the licensee's compliance with the conditions placed on the license. The most important condition that will be placed on the license is that the licensee will submit data annually to INDOT to verify that the discharge has not polluted. Another condition of the license will require the property owner to install structural measures to keep floatable materials and other pollutants from entering INDOT right-of-way. If the property is sold, it will be the responsibility of the seller to inform the buyer that they are required to transfer the license to their name. If the owner ceases to operate or otherwise losses control of the property, it is their responsibility as licensee to inform INDOT of the change in land-use, operation, or control. INDOT will then investigate the disposition of the property and the discharge to the right-of-way, and take appropriate action.

INDOT will develop a program to systematically re-evaluate those existing discharges that were allowed onto the right-of-way in the past, and require the development or developer or property owner to apply for a Discharge to Rightof-way License and provide storm water quality data to verify that the discharge does not contain pollutants. Also the property owner may be required to install structural measures to keep floatable materials and other pollutants from entering INDOT right-of-way.

\section{Storm Water Drainage Maps}

IDEM's NPDES Rule for storm water runoff in MS4 areas requires that, a storm sewer system map showing the location of all outfalls and ...conveyances, be developed. INDOT has all of the drainage systems, outfalls, bridges, and conveyances on project plans and as-built drawings in various formats, hard copy or electronic, for every highway under their jurisdiction. It would be redundant and costly to re-map the INDOT highway drainage system just for this permit. However, INDOT is currently in the process of developing a Geographic Information System (GIS) for all of the highways under its jurisdiction, a GIS layer will be developed on which the drainage systems, outfalls, bridges, and conveyances shall be located. Therefore, it is INDOT's position that this mapping requirement has been fulfilled. However, outfalls will be located with Global 
Positioning Satellite (GPS) and labeled (mapping) during sampling and testing according to the INDOT priority system of sensitive waters.

\section{Measurable Goals}

Measurable goals, which are required for each minimum control measure, are intended to gauge permit compliance and program effectiveness. At a minimum, the measurable goal for this program would be to provide an Illicit Discharge Detection and Reporting System and a Storm Water Control Policy.

The following are the measurable goals for INDOT's Illicit Discharge Detection and Elimination Program for the initial five (5) year permit period.

\begin{tabular}{|c|c|}
\hline Target Date & Activity \\
\hline $\begin{array}{l}\text { Year } 1 \\
\text { November 1, } 2003 \text { to } \\
\text { October } 31,2004\end{array}$ & $\begin{array}{l}\text { - Develop written procedures for reporting illicit } \\
\text { discharges by July } 2004 \text {. } \\
\text { - Develop a training program for INDOT field employees } \\
\text { to identify illicit discharges by September } 2004 \text {. }\end{array}$ \\
\hline $\begin{array}{l}\text { Year } 2 \\
\text { November } 1,2004 \text { to } \\
\text { October } 31,2005\end{array}$ & $\begin{array}{l}\text { - Conduct training for INDOT field employees to identify } \\
\text { illicit discharges and to know the documentation and } \\
\text { reporting procedures September } 2005 \text {. } \\
\text { - INDOT will begin developing a Discharge to Right-of- } \\
\text { way License, it may require legislative action. } \\
\text { Develop GIS system for mapping INDOT infrastructure, } \\
\text { including drainage conveyances and discharge points, } \\
25 \% \text { complete by October } 31,2005 \text {. }\end{array}$ \\
\hline $\begin{array}{l}\text { Year } 3 \\
\text { November } 1,2005 \text { to } \\
\text { October } 31,2006\end{array}$ & $\begin{array}{l}\text { - Conduct training for INDOT field employees to identify } \\
\text { illicit discharges and to know the documentation and } \\
\text { reporting procedures September } 2006 \text {. } \\
\text { - Continue to develop the Discharge to Right-of-way } \\
\text { License. } \\
\text { - Continue developing GIS system for mapping INDOT } \\
\text { infrastructure, including drainage conveyances and } \\
\text { discharge points, } 50 \% \text { complete by October } 31,2006 \text {. }\end{array}$ \\
\hline $\begin{array}{l}\text { Year } 4 \\
\text { November } 1,2006 \text { to } \\
\text { October } 31,2007\end{array}$ & $\begin{array}{l}\text { - Conduct training for INDOT field employees to identify } \\
\text { illicit discharges and to know the documentation and } \\
\text { reporting procedures September } 2006 \text {. } \\
\text { Evaluation of the field employees training and illicit } \\
\text { discharge detection and reporting procedures will be } \\
\text { performed, January } 2007 \text {. } \\
\text { - Continue to develop the Discharge to Right-of-way } \\
\text { License. } \\
\text { Continue developing GIS system for mapping INDOT } \\
\text { infrastructure, including drainage conveyances and } \\
\text { discharge points, } 75 \% \text { complete by October } 31,2007 \text {. }\end{array}$ \\
\hline $\begin{array}{l}\text { Year } 5 \\
\text { November } 1,2007 \text { to } \\
\text { October } 31,2008\end{array}$ & $\begin{array}{l}\text { - Finalize the Discharge to Right-of-way License, 03/08. } \\
\text { - Begin issuance of Discharge to Right-of-way Licenses } \\
\text { by October } 1,2008 \text {. }\end{array}$ \\
\hline
\end{tabular}


- Continue developing GIS system for mapping INDOT infrastructure, including drainage conveyances and discharge points, $100 \%$ complete by October 31,2008 .

\section{CONSTRUCTION SITE STORM WATER RUNOFF CONTROL}

(See RULE 5, 327 IAC 15-5-1), one (1) acre or more of disturbed soil

\section{A. Benefits of INDOT's Construction Site Program}

Storm water runoff from highway construction sites ultimately discharges into local ditches, creeks, streams, lakes, and rivers. Sediment is usually the main pollutant of concern. During a short period of time, construction sites can contribute more sediment to streams than would be deposited naturally over several decades. The resulting siltation, and the contribution of other pollutants from construction sites, can cause physical, chemical, and biological harm to waters of the State. Excess sediment can quickly fill ditches and lakes and require dredging and destroy aquatic habitats.

Additional pollutants are also often present in storm water runoff from highway construction sites and may result in degradation of receiving water. Nutrients (nitrogen and phosphorous) are of specific concern and can cause significant impairment. In addition solid and sanitary wastes, pesticides, oil and grease, concrete truck washout, construction chemicals, construction debris and metals may be discharged and cause an impact to the waters of the State.

Erosion Control Plans, Standard Specifications, and Standard Drawings of erosion control measures are components of INDOT's Construction Site Storm Water Runoff Control Program. With the development of an Inspection Program and Enforcement Program INDOT will be able to further minimize the amount of sediments that are discharged to waters of the State during highway construction.

\section{B. Program Requirements}

To paraphrase the Rule 13 regulations (327 IAC 15-13-15) into requirements that may be used for an individual NPDES permit for INDOT:

INDOT shall comply with Rule 5, 327 IAC 15-5

INDOT shall complete and submit a state-issued certification form to the department once the regulatory mechanism for inspection and enforcement has been developed and implemented, or three hundred sixty-five (365) days from the date of permit issuance, whichever is earlier. At a minimum, every five (5) years the program shall be reviewed for adequacy and accuracy and updated as necessary.

\section{Guidelines for Developing and Implementing This Measure}

1. Minimum Design Criteria

INDOT Standard Specification, Section 205, and 
current Supplemental Specifications

INDOT Standard Drawings, Section 205

a. Best Management Practices (BMP's)

i. Preventive Measures; minimize disturbance area of excavation, preserve natural vegetation, good housekeeping.

ii. Erosion Controls; mulch, seed mix, stockpile covers.

iii. Sediment Controls; perimeter silt fence, inlet protection, check dams, stabilized construction entrances, sediment basins.

iv. Drainage Conveyance Controls; check dams, diversion channels, temporary crossings.

v. Non-Sediment Controls; cover chemical storage, spill containment and procedures, waste containment. The contractor performing the actual operations must comply with Section 311 of the Federal Clean Water Act and with 327 IAC 2-6 concerning spills of oil and hazardous materials.

\section{b. Stabilization}

i. Temporary Stabilization; maximum bare soil exposure time limit if the excavation operation has been inactive for 14 days, or more

ii. Seasonal Stabilization; if construction ceases for a season, i.e. over the winter

iii. Final Stabilization; permanent seeding, sodding or other stabilization measures.

\section{c. Materials Handling}

The contractor will be required to take steps to control waste, discarded building materials, concrete truck washout, chemicals, litter, and sanitary waste from leaving the work site or staging area and being washed into waters of the State.

\section{Control Mechanism}

New contract provisions will be developed to strengthen existing Standard Specifications and to require the contractor to routinely document inspects of the erosion control BMP's. The BMP's must be inspected weekly and after a rain event at the site, per the current Supplemental to INDOT Standard Specifications, Section 205.04 Maintenance. Any damage to the BMP will be repaired.

Contractors will be required to submit a Quality Control Plan before beginning construction. An outline of the Quality Control Plan is as follows:

\section{REFERENCES.}

a. Rule 5, 327 IAC 15-5

b. Indiana Handbook for Erosion Control in Developing Areas 
-Indiana Department of Natural Resources, Division of Soil Conservation

c. Indiana Drainage Handbook

-Indiana Department of Natural Resources, Division of Water

Quality Control Technician Training

Contractor must have at least one qualified person on-site to inspect and supervise the maintenance of the erosion control measures (BMP's). This person will have completed the training provided by the Indiana Department of Natural Resources (IDNR), or approved equal, and pass an INDOT exam (biannually) proving they have acquired the skills and abilities in erosion control measures installation, inspection, and maintenance.

Quality Control Inspection
a. Quality Control Inspection Points
b. Quality Control Inspection Frequency
c. Documentation of Quality Control Inspections
d. Corrective Action on deficiencies within five (5) working days

Work Sequence Schedule (include Borrow or Disposal Area, Haul Roads, etc.) on INDOT Right-of-way or Property as outlined in the Contract

Pollution Control Plan (Staging Area)
a. Containment Procedures
b. Waste Disposal Plan
c. Spill Prevention and Protection Plan
d. Spill Clean-up Plan
e. Materials Stockpiles and Materials Storage Management
f. Entrance and Exit treatment to prevent tracking of mud off site
g. Concrete truck washing area management

3. Storm Water Runoff Control Site Plans (Erosion Control Plan)

a. Procedures for reviewing and approving storm water control site plans (erosion control plan): Currently IDNR intends to review INDOT erosion control plans. The Notice Of Intent letter (NOI) is to be submitted to IDEM, with copies to IDNR and local Soil Water Conservation District (SWCD).

b. System to track the effectiveness of the storm water control site plan (erosion control plan): An audit program to periodically inspect construction projects for BMP effectiveness shall be conducted by the Division of Environment, Planning, and Engineering, Environmental Services Section. INDOT shall provide adequate project oversight to prevent inadequate storm water control plans from being implemented, thus allowing degradation of waters of the State. 
4. Inspections and Enforcement

\section{a. Inspection Program}

i. Routine and Scheduled Self Inspections by the Contractor.

INDOT contractors will be required to perform and document self inspections. Self inspections will be performed weekly, preferably on Monday morning when crews are returning to work from a week end off. Self inspections will be conducted after a rain event at the site, within the first work day after the rain event. INDOT shall develop and provide the contractor with standardized inspection forms.

ii. Compliance Inspections.

IDNR personnel may conduct unscheduled (surprise) inspections to assess the over-all site and erosion control plan and BMP's for compliance. INDOT Project Engineers or Project Supervisors will periodically inspect portions of the BMP's to assure that the contractor is performing the necessary maintenance properly.

iii. Complaint Response Inspections.

If a complaint is lodged by the public or another agency (IDNR or Soil and Water Conservation District) stating that the erosion control measures at the construction site are not adequate, a INDOT representative will meet with the contractor's representative to address the issues. If the contractor does not take steps to correct the issues in a set period of time (determined at the meeting), then INDOT will proceed with enforcement action. IDNR may be involved throughout this process, if they so desire.

\section{b. Enforcement Procedures}

INDOT Standard Specification 108.06.

i. Failure to Install BMP's Correctly.

(1) The INDOT Project Engineer/Supervisor shall inform the contractor that an erosion control measure is not installed properly.

(2) If not corrected in a timely manner, a Notice of Violation (NOV) letter will be issued by the Project Engineer, by the third $\left(3^{\text {rd }}\right)$ calendar day after the contractor was informed.

(3) If not corrected within five (5) calendar days, a fine of $\$ 1,000$ per day that the problem persists will be levied, retroactive to the first notification date. Therefore a $\$ 5,000$ fine will be assessed at the end of the fifth calendar day, and $\$ 1,000$ per day there after.

ii. Failure to Maintain BMP's.

(1) The INDOT Project Engineer/Supervisor shall inform the contractor that an erosion control measure is not being maintained properly.

(2) If not corrected in a timely manner, a Notice of Violation (NOV) letter will be issued by the Project Engineer, by the third $\left(3^{\text {rd }}\right)$ calendar day after the contractor was informed. 
(3) If not corrected within five (5) calendar days, a fine of $\$ 1,000$ per day that the problem persists will be levied, double-retroactive to the first notification date. Therefore a $\$ 10,000$ fine will be assessed at the end of the fifth calendar day, and $\$ 1,000$ per day there after.

iii. Failure to Perform Routine and Documented Inspections.

(1) The INDOT Project Engineer/Supervisor shall inform the contractor that documented inspection have not been performed.

(2) If five (5) calendar days pass without a documented inspection, a fine of $\$ 5,000$ will be levied, and a fine of $\$ 1,000$ per day that the problem persists will be levied beginning the sixth day.

5. Training and Education for Construction Site Supervisors, Project Engineers, inspectors, designers, and technicians.

IDNR has indicated that they are revising the Indiana Handbook for Erosion Control in Developing Areas for the NPDES Phase II Rules. IDNR is developing a program to train erosion control inspectors and technicians. INDOT Project Engineers, Project Supervisors, design engineers, and technicians shall be trained for erosion control inspection by IDNR.

\section{Measurable Goals}

These measurable goals reflect the needs and characteristics of INDOT as it serves the people of Indiana and the traveling public. The following are the measurable goals for INDOT's Construction Site Storm Water Runoff Control Program for the initial five (5) year permit period.

\begin{tabular}{|c|c|}
\hline Target Date & Activity \\
\hline $\begin{array}{l}\text { Year } 1 \\
\text { November } 1,2003 \text { to } \\
\text { October } 31,2004\end{array}$ & $\begin{array}{l}\text { Pre-construction Conference with Contractor shall } \\
\text { include an item to discuss the importance of erosion } \\
\text { control maintenance, by March } 2004 \text {. } \\
\text { - INDOT Design manual shall be changed to require the } \\
\text { designer to develop erosion control plans for projects } \\
\text { that disturb at least one (1) acre of ground, by June } 2004 \text {. } \\
\text { - Develop standardized inspection forms by June } 30 \text {, } \\
2004 \text {. }\end{array}$ \\
\hline $\begin{array}{l}\text { Year } 2 \\
\text { November 1, } 2004 \text { to } \\
\text { October } 31,2005\end{array}$ & $\begin{array}{l}\text { - INDOT Project Engineers, Project Supervisors, design } \\
\text { engineers, and technicians shall be trained for erosion } \\
\text { control inspection by IDNR, as time permits, beginning } \\
\text { November } 2004 \text {. } \\
\text { - Begin developing Quality Control Plan required by } \\
\text { contractor for erosion control, November } 2004 \text {. } \\
\text { - Implement standardized inspection forms by December } \\
31,2004 \text {, to be used on-site by trained inspectors. }\end{array}$ \\
\hline $\begin{array}{l}\text { Year } 3 \\
\text { November } 1,2005 \text { to }\end{array}$ & $\begin{array}{l}\text { - INDOT Project Engineers, Project Supervisors, design } \\
\text { engineers, and technicians shall continue to be trained }\end{array}$ \\
\hline
\end{tabular}




\begin{tabular}{|c|c|}
\hline October 31,2006 & $\begin{array}{l}\text { for erosion control inspection by IDNR, as time permits. } \\
\text { - Develop Enforcement Procedure for contractor non- } \\
\text { compliance of erosion control maintenance, November } \\
2005 \text {. } \\
\text { - Implement standardized inspection forms to be used by } \\
\text { the contractor as of August } 2006 \text { contracts. } \\
\text { - Continue developing Quality Control Plan required by } \\
\text { contractor for erosion control. }\end{array}$ \\
\hline $\begin{array}{l}\text { Year } 4 \\
\text { November } 1,2006 \text { to } \\
\text { October } 31,2007\end{array}$ & $\begin{array}{l}\text { - INDOT Project Engineers, Project Supervisors, design } \\
\text { engineers, and technicians shall continue to be trained } \\
\text { for erosion control inspection by IDNR, as time permits. } \\
\text { - Implement Enforcement Procedure for contractor non- } \\
\text { compliance of erosion control maintenance, March } \\
2007 \text {. } \\
\text { - Implement Quality Control Plan for erosion control, } \\
\text { required by contractor as of November } 2006 \text { contracts. } \\
\text { - Develop an audit program to periodically inspect } \\
\text { construction projects for BMP effectiveness, December } \\
2006 \text {. }\end{array}$ \\
\hline $\begin{array}{l}\text { Year } 5 \\
\text { November } 1,2007 \text { to } \\
\text { October } 31,2008\end{array}$ & $\begin{array}{l}\text { - Implement an audit program to periodically inspect } \\
\text { construction projects for BMP effectiveness, April } 2008 \text {. } \\
\text { - Audit } 25 \% \text { of the construction projects for erosion } \\
\text { control compliance, } 2008 \text { construction season. }\end{array}$ \\
\hline
\end{tabular}

\section{POST CONSTRUCTION STORM WATER MANAGEMENT}

\section{A. Benefits of INDOT's Post Construction Storm Water Management Program}

Post-construction storm water management in areas undergoing new development or redevelopment is necessary because runoff from these areas has been shown to significantly affect receiving water bodies. Many studies indicate that prior planning and designing for the minimization of pollutants in post-construction storm water discharges is the most cost-effective approach to storm water quality management.

There are three (3) forms of impact from post-construction runoff:

(1) Increase in the type and quantity of pollutants in storm water runoff. As runoff flows over areas altered by development, it picks up harmful sediment and chemicals such as oil and grease, pesticides, heavy metals, and nutrients (e.g., nitrogen and phosphorus). These pollutants often become suspended in runoff and are carried to receiving waters.

(2) Increase in the quantity of water delivered to the water body during storms. Increased impervious surfaces impede the gradual infiltration of water through vegetation and soil. Instead, water is collected from surfaces such as asphalt and concrete and routed to drainage systems where large volumes of runoff quickly flow to the nearest receiving water. The results include stream bank scouring and downstream flooding, lending to a loss of aquatic life and damage to property. 
(3) Increase in the temperature of water delivered to the water body during storms. Increased impervious surfaces such as asphalt and concrete have higher temperatures and do not allow for the natural infiltration through vegetation and soil that would keep the runoff at an ambient temperature. Therefore large volumes of runoff with higher temperatures quickly flow to the nearest receiving water and in-turn elevate the stream temperature. Thermal impact to streams and rivers causes less oxygen dissolution and other degradation of conditions conducive to support aquatic life.

\section{B. Program Requirements}

To paraphrase the Rule 13 regulations (327 IAC 15-13-16) into requirements that may be used for an individual NPDES permit for INDOT:

INDOT shall develop an SWQMP that includes a commitment to develop, implement, manage, and enforce a program to address discharges of postconstruction storm water run-off from new development and redevelopment areas which disturb one (1), or more, acre of land.

INDOT shall promote the use of:

(1) Buffer strip and riparian zone preservation.

(2) Filter strip creation.

(3) Minimization of land disturbance and surface imperviousness.

(4) Minimization of directly connected impervious areas.

(5) Maximization of open space.

INDOT shall use any combination of storage, infiltration, filtering, or vegetative practices to reduce the impact of pollutants in storm water run-off on receiving waters. In addition to the combination of practices, the following requirements shall be utilized:

(1) Infiltration practices will not be allowed in wellhead protection areas.

(2) Discharges from the highway right-of-way will not be allowed directly into sinkholes or fractured bedrock, without treatment that results in the discharge meeting Indiana ground water quality standards as referenced in 327 IAC 211.

(3) Any storm water practice that is a Class V injection well must ensure that the discharge from such practices meets Indiana ground water quality standards as referenced in 327 IAC 2-11

(4) As site conditions allow, a vegetated filter strip of appropriate width shall be maintained along unvegetated swales and ditches.

(5) As site conditions allow, the rate at which water flows through the highway conveyance shall be regulated to reduce outfall scouring and stream bank erosion.

(6) For new retail gasoline outlets and refueling areas that replace their existing tank systems, (for Toll Road Facilities only); these facilities shall be required by contractual means to design and install appropriate practices to reduce lead, copper, zinc, and polyaromatic hydrocarbons in storm water run-off.

INDOT personnel responsible for plan review, inspection, and enforcement of post-construction BMPs shall attend, at a minimum, an annual training session addressing appropriate control measures that have been approved of by the department and the department of natural resources, division of soil conservation. 
INDOT shall complete and submit a state-issued certification form to the department once the plan has been developed and implemented, or seven hundred thirty (730) days from the date of permit issuance, whichever is earlier. At a minimum, every five (5) years the program shall be reviewed for adequacy and accuracy and updated as necessary.

INDOT shall develop measurable goals for this measure

\section{Guidelines for Developing and Implementing This Measure}

INDOT will encourage designers to incorporate BMP's into the design of highways to address:

- Buffer strip and riparian zone preservation (along ditches, creeks, streams, rivers, wetlands, and lakes).

- Filter strip creation (highway side slopes).

- Minimization of land disturbance and impervious surface, wherever practicable.

- Minimization of impervious areas directly connected to waters of the State.

Storage or detention BMP's control storm water by providing a wet pond, dry basin, or multi-chambered catch basin to collect and slowly release runoff to receiving waters. These practices control storm water volume, settle out particulates, and reduce thermal impacts to receiving waters.

Infiltration practices are designed to facilitate the percolation of runoff through the soil to groundwater, thereby reducing both storm water quantity and mobilization of pollutants. These BMP's incorporate pervious mediums into the design to filter the water.

Vegetative practices are landscaping features that, with optimal design and good soil conditions, enhance pollutant removal, maintain/improve natural site hydrology, promote healthier habitats, and increase aesthetic appeal. Vegetative BMP's include filter strips or buffer strips, grassy swales, and artificial (constructed) wetlands.

Currently INDOT, in accordance with a Memorandum of Understanding (MOU) with IDEM, has a BMP design for storm water discharge from an INDOT highway right-ofway into sink holes in the karst topography regions of Indiana. There have been a number of these BMP's installed along SR 37 in Lawrence County.

\section{Measurable Goals}

These measurable goals reflect the needs and characteristics of INDOT as it serves the people of Indiana and the traveling public. The following are the measurable goals for INDOT's Post Construction Storm Water Management Program for the initial five (5) year permit period. 


\begin{tabular}{|c|c|}
\hline Target Date & Activity \\
\hline $\begin{array}{l}\text { Year } 1 \\
\text { November 1, } 2003 \text { to } \\
\text { October } 31,2004\end{array}$ & $\begin{array}{l}\text { - Develop Design Criteria for Post Construction BMP's, } \\
\text { current JTRP Project, begin November 1, 2003. } \\
\text { - Develop Standard Operating Procedures for the } \\
\text { maintenance of Storm Water BMP's, begin October 1, } \\
2004 \text {. }\end{array}$ \\
\hline $\begin{array}{l}\text { Year } 2 \\
\text { November 1,2004 to } \\
\text { October 31, 2005 }\end{array}$ & $\begin{array}{l}\text { - Continue to develop Design Criteria for Post } \\
\text { Construction BMP's, current JTRP Project. } \\
\text { - Continue to develop Standard Operating Procedures for } \\
\text { the maintenance of Storm Water BMP's. }\end{array}$ \\
\hline $\begin{array}{l}\text { Year } 3 \\
\text { November 1, } 2005 \text { to } \\
\text { October } 31,2006\end{array}$ & $\begin{array}{l}\text { - Implement new design criteria for BMP's, October } 1 \text {, } \\
2006 \text {. }\end{array}$ \\
\hline $\begin{array}{l}\text { Year } 4 \\
\text { November 1, } 2006 \text { to } \\
\text { October } 31,2007\end{array}$ & $\begin{array}{l}\text { - Continue to implement new design criteria for BMP's. } \\
\text { - Implement the new Standard Operating Procedures for } \\
\text { the maintenance of Storm Water BMP's, begin October } \\
1,2007 \text {. }\end{array}$ \\
\hline $\begin{array}{l}\text { Year } 5 \\
\text { November 1, } 2007 \text { to } \\
\text { October } 31,2008\end{array}$ & $\begin{array}{l}\text { - Evaluate the new design criteria for BMP's for } \\
\text { effectiveness and cost, proposed JTRP Project, begin } \\
\text { October 1,2008. } \\
\text { - Evaluate the new Standard Operating Procedures for the } \\
\text { maintenance of Storm Water BMP's for man hour } \\
\text { allocation, effectiveness, common problems, and cost, } \\
\text { proposed JTRP Project, begin October 1,2008. }\end{array}$ \\
\hline
\end{tabular}

VI. POLLUTION PREVENTION AT INDOT OPERATION AND MAINTENANCE FACILITIES and for ROAD SIDE MAINTENANCE/ GOOD HOUSEKEEPING

\section{A. Benefits of INDOT's Good Housekeeping Program}

The Pollution Prevention/Good Housekeeping Program for INDOT is a key element of the Storm Water Quality Management Plan. This measure requires INDOT to examine and subsequently alter it's activities to help ensure a reduction in the amount and type of pollution that; (1) collects on highways, parking lots at rest areas and operation and maintenance facilities, open spaces, stored aggregate materials, and vehicle maintenance areas and is discharged into waters of the State; and (2) results from activities such as highway maintenance, and poor maintenance of storm sewer systems. While this measure is meant primarily to improve or protect receiving water quality by altering INDOT activities, facility operations and property maintenance, INDOT can realize cost savings from such things as spill prevention (thus reducing clean-up costs), inventory control, and re-use/recycling of materials.

\section{B. Program Requirements}

To paraphrase the Rule 13 regulations (327 IAC 15-13-17) into requirements that may be used for an individual NPDES permit for INDOT: 
INDOT shall develop a SWQMP that includes a commitment to develop and implement a program to prevent or reduce pollutant run-off from operations.

INDOT shall complete and submit a certification form to the department once the program has been developed and implemented, or three hundred sixty-five (365) days from the date of NOI letter submittal, whichever is earlier. At a minimum, every five (5) years the program shall be reviewed for adequacy and accuracy and updated as necessary.

INDOT shall develop written documentation of maintenance activities, maintenance schedules, and long term inspection procedures for BMPs to reduce floatables and other pollutants discharged from separate storm sewers. Maintenance activities shall include, as appropriate, the following:

(A) Periodic litter pick up

(B) Periodic BMP structure cleaning

(C) Periodic pavement sweeping

(D) Roadside shoulder and ditch stabilization.

(E) Planting and proper care of roadside vegetation.

(F) Remediation of outfall scouring conditions

INDOT shall develop controls for reducing or eliminating the discharge of pollutants from operational areas, including roads, parking lots, maintenance and storage yards. Appropriate controls shall include the following:

1) Covering or otherwise reducing the potential for polluted storm water run-off, from deicing salt or sand storage piles.

2) Establishing designated snow disposal areas that have minimal potential for pollutant run-off impact on receiving waters.

3) Providing facilities for containment of any accidental losses of concentrated solutions, acids, alkalies, salts, oils, or other polluting materials

4) Standard operating procedures for spill prevention and clean up during fueling operations; spill prevention, controls and countermeasures plan (SPCC plan) per 40 CFR Part 112

5) BMPs for vehicular maintenance areas.

6) Prohibition of equipment or vehicle wash waters and concrete or asphalt hydro demolition waste waters into storm water run-off, except under allowance of an appropriate NPDES wastewater permit

7) Promotion of recycling (to reduce litter).

8) Minimization of pesticide, herbicide and fertilizer use. Pesticides shall be used, applied, handled, stored, mixed, loaded, transported, and disposed of via office of the Indiana State Chemist's guidance requirements.

9) Proper disposal of animal waste and road-kill. Canine parks shall be sited at least one hundred fifty (150) feet away from surface water body.

INDOT shall develop written procedures for the proper disposal of waste removed from separate storm sewer systems and operational areas. All materials removed from separate storm sewer systems and operational areas, including dredge spoil, accumulated sediments, floatables, and debris, must be:

1) Reused or recycled; or

2) Disposed of in accordance with applicable solid waste disposal regulations.

INDOT shall develop written documentation that appropriate employees have been properly trained, with periodic refresher sessions, on topics such as proper disposal of hazardous wastes, vegetative waste handling, fertilizer, herbicide and pesticide application, and the function of implemented BMPs 
INDOT shall develop measurable goals for this measure.

\section{Guidelines for Developing and Implementing This Measure}

The intent of this control measure is to ensure that existing and future highway and facility operations and maintenance are performed in ways that will minimize contamination of storm water runoff. This measure is divided into two areas under INDOT control:

- Highway and roadside maintenance

- Facilities operation and maintenance

Under each of these categories the following pollution prevention measures are addressed:

- Waste management (recycling)

- Ground surface stabilization (erosion control)

- Structural runoff controls (materials storage cover and runoff containment)

- Snow removal and de-icing

\section{Highway and Roadside Maintenance}

INDOT uses a Field Operations Handbook to guide maintenance workers in their tasks of maintaining the pavement, shoulders, side slopes, ditches, and rest areas. Those operations from the Handbook that are pertinent to storm water quality for Highway and Roadside Maintenance are:

Clipping Shoulders - Major clipping of overgrown shoulders to remove excess material and to restore proper slope for adequate drainage. Includes clipping of overgrown shoulders adjacent to the driving surface and sod adjacent to paved or aggregate shoulder. Also includes related cleaning and reshaping of the adjacent roadside ditches as required.

Machine Mowing - Machine mowing of roadside vegetation within the designated mowing limits of the right-of-way using tractor mowers and hand trimming as required, to maintain an attractive roadside and to control erosion and drainage. This activity does not include the hand mowing and trimming at rest areas, roadside parks and picnic areas.

Brush Cutting - Cutting, trimming and removing brush, small trees, tree branches and limbs within the right-of-way using power or hand tools to restore sight distance, eliminate traffic hazards and remove encroaching vegetation.

Herbicide Treatment - Application of chemicals to roadside vegetation and soil along shoulders, guardrail sections, around sign posts, delineators, mail boxes, bridge ends and other areas to eliminate or control undesirable vegetation. 
Seed and/or Fertilizing - Seeding, reseeding, and fertilizing of shoulders, front and back slopes, medians and other designated areas to restore vegetation for erosion control and beautification.

Topping Trimming or Removal of Trees - Topping, trimming or removal of large trees within the right-of-way requiring the use of equipment such as a bucket truck and a boom truck. Includes stump removal when performed as a part of the tree operation.

Stump Removal - Removal of stumps within the right-of-way to eliminate traffic hazards or improve efficiency of other maintenance activities. (Stump cutting performed in conjunction with tree removal should be reported to Activity 2250)

Spot Mowing and Hand Trimming - Spot or hand mowing to control Johnson grass, Canadian thistle and other noxious weeds, and hand trimming or mowing needed in addition to that performed during Machine Mowing (Activity 2210). This activity does not include hand mowing or trimming at rest areas, roadside parks, districts, Subdistrict or unit location.

Clean and Reshape Ditches - Machine cleaning of roadside ditches with excavating equipment to restore original grade and maintain adequate drainage. Includes the loading, hauling, and disposal of excess material, reshaping front and back slopes, and shoulder restoration as related to ditching. May also include pipe replacement in the ditch line and under driveways.

Motor Patrol Ditching - Machine cleaning of roadside ditches with motor patrol to restore original grade and maintain adequate drainage. Includes the loading, hauling, and disposal of excess material, reshaping front and back slopes, pipe culvert replacement and shoulder restoration as related to ditching.

Cleaning Minor Drainage Structures - Manual or machine cleaning and removal of debris from box culverts, pipe culverts, catch basins, inlets and paved ditches to maintain adequate drainage.

Clean Underdrains - Clean inside and outside of underdrains pipes to restore adequate drainage flow. Mark locations of outlets.

Other Drainage Maintenance -Other routine drainage maintenance activities that are not specifically identified as separate activities.

Hand Cleaning Bridges - Cleaning of bridge deck surfaces, expansion joints, drains holes, bridge seats and sidewalks by hand shoveling, sweeping and air blasting to remove accumulation of sand, chemicals and debris. 
Flushing Bridge - Cleaning of bridge seats, drain holes, expansion joints, gutter lines and truss members by flushing to remove accumulation of sand, chemicals, and debris.

Snow and Ice Removal - This activity includes all operations during and after a storm required to remove snow and ice from the roadway. Includes loading operations required to support snow and ice removal operations, removal of snow from ditches, removal of ice caused by flooding and opening of frozen drains.

Other Winter Maintenance - Other routine winter maintenance activities that are not specifically identified as separate activities.

Rest Area and Lift Bridge Attendant - The care and cleaning of rest areas and enforcement of INDOT policies for rest areas and enforcement of INDOT policies for rest area usage and operation of lift bridges on the State Highway system by full time attendants.

Roadside Park, Rest Area and Weigh Station Maintenance - Maintenance of building, grounds and parking lots of state maintained rest areas, roadside parks and weigh stations. This activity is performed on interstate only. All other such work is reported to Facilities Activities (2830+Subactivity)

Work for Department of Natural Resources - All maintenance activities performed on the designated roadways and parking areas of the Indiana Department of Natural Resources.

Work for State Institutions - All maintenance activities performed on the designated roadways of the State of Indiana institutions.

Full Width Litter Pickup - Full width cleaning of continuous sections of the right-of-way area including pickup, loading, hauling and disposing of accumulated litter to remove unsightly or hazardous objects and obstructions to drainage.

Currently INDOT has a program called Trash Bash. This program involves picking up trash along the right-of-way each Spring before mowing begins. Division of Corrections labor is also utilized for the trash pickup.

Spot Litter Pickup - Cleaning isolated sections of the right-of-way including pickup, loading and disposing of litter and debris to remove unsightly or dangerous objects.

Roadway Cleaning - Mechanical or manual sweeping of roadway, including intersections, curbs and gutters, to remove excess loose sand, chemicals, and debris. Manual cleaning of bridges should be reported as Activity 2410, Hand Cleaning Bridge Decks. 
Material Handling and Storage - Handling and storage materials for routine maintenance activities excluding snow and ice control materials. Includes the loading, hauling, unloading, mixing, stockpiling, and storage of material. See also SALT AND DE-ICER MATERIALS HANDLING in Section 2. below.

\section{ADOPT-A-HIGHWAY}

Currently INDOT has a program called Adopt-A-Highway that involves community groups taking responsibility for designated sections of a highway to clean, maintain, and beautify with landscaping, if desired. In turn INDOT places a standard Adopt-A-Highway sign acknowledging the community organization responsible for the beautification of the highway. These segments of highway are in municipalities or near urbanized areas in which the organization is located.

\section{Facilities Operation and Maintenance}

Those operations from the Field Operations Handbook that are pertinent to storm water quality for Operations and Maintenance Facilities are:

Stockpiling Winter Material - The stockpiling, mixing and processing of abrasives and chemicals performed before and during the winter season.

Equipment Servicing - The routine service and maintenance of the Department's equipment fleet.

Buildings \& Grounds Maintenance - The general maintenance and caretaking of the buildings and grounds at District, Subdistrict, and other maintenance unit locations.

Scraping and Painting of Equipment - Manual scraping of loose paint to remove from equipment. Rust should also be removed. Painting equipment to improve appearance and to increase life span of equipment. Note: When Unit Foreman or crew leaders are working as a part of a crew (not supervising other crews) their time is to be reported to the activity they are performing.

\section{SALT AND DE-ICER MATERIALS HANDLING}

INDOT has created a Winter Operations Team that meets on a regular basis and has produced a manual for storm water management, Total Storm Management Manual, 2/2/02. Chapter three (3) of this manual is titled, Environmental Issues, and covers topics such as, Environmental Consideration, Pollution Control, Administration and Supervision, Site Analysis, Drainage, Design of Brine Storage / Evaporation Facilities, and Guidelines.

INDOT currently has two Standard Operating Procedures, for field operations and maintenance personnel, that deal specifically with snow and ice removal. 
Procedure No. 2, SNOW AND ICE CONTROL, revised January/March 2001, provides for a uniform understanding and establishes guidelines for achieving the Department's goals and objectives for snow and ice control. This procedure classifies the different state highways based on their level of service so priorities may be set in the snow and ice removal schedules. Procedure No. 2 covers, Responsibilities, Preparation for Winter, Operations, and Post Winter Operations, with detailed guidance on Equipment Inspection, Spreader Calibration, Materials Stockpiling, Training, Material Applications, and Equipment Cleanup. Procedure No. 22, SNOW AND ICE CHEMICALS POLLUTION CONTROL GUIDELINES, revised July 1998, provides ...that we take appropriate action at each and every location to create a clean environment. This procedure further states, ...it is imperative that we take every reasonable precaution to insure that we have established a course of responsible salt management and instilled a level of conscious awareness within the work force that "an ounce of prevention is worth a pound of cure". Procedure No. 22 covers, Priority, Site Analysis, Drainage, Design of Brine Storage/Evaporation Facilities, Mixing/Handling of Deicing Chemicals, Sensible Salting, and Cleanup if Existing Facilities.

INDOT Salt Housekeeping Guidelines for Personnel Involved in Snow Removal, was issued by Memorandum from the Office of Chief Engineer/Highway Operations, dated October 2, 1998. These guidelines provide detailed instructions to operations personnel to eliminate excess salt releases to the environment. The guidelines cover salt delivery, Fall preparation, liquid chemical handling, salt operations during the storm, salt operations after the storm, post season concerns, and spill procedures.

All INDOT salt storage is currently under roof. INDOT has initiated a program to construct salt/sand mixing buildings that are connected to the covered salt piles (salt domes). Incorporated into these multi-structure salt mixing facilities is the capture, retention, and use (or disposal) of all water runoff. The runoff is stored in a tank for use as brine, a salt/water solution.

Brine is used as a pre-wetting agent, and sometimes in lieu of salt when the temperature is optimum. Using brine minimizes the amount of salt needed and speeds the process of salt melting ice and snow.

INDOT has developed a Liquid Chemical Application Policy specific for the Greenfield District. The Goals and Mission Statement for the Greenfield District Liquid Chemical Application Policy are:

INDOT's goal is to provide continuous service to roadways to remove snow and ice from the pavement surface (Operating Procedure 2, Jan. 2001). For interstate routes and other roads with an annual daily traffic (ADT) count greater than 5,000, the coverage is 6 routes per $(12 \mathrm{hr}$.) shift.

Liquid chemicals are used to aid in obtaining the high level of service and as a measure to conserve salt usage. There are four basic uses for liquid deicing chemicals: anti-icing, deicing, frost-prevention, and pre-wetting. 
The District goal of anti-icing is to pre-treat $100 \%$ of roadways as equipment availability allows and as conditions require. This will be accomplished on a per storm basis as directed by call out of personnel. Continuity of service shall be the common aim of all units.

Similar policies can be written for other INDOT Districts.

INDOT has written a Spill Prevention, Control, and Countermeasures Plan that describes how facilities are to respond to unintended releases of the liquid petroleum products and liquid deicing storage to meet the needs of each location. INDOT is moving toward zero underground storage tanks. Currently INDOT has only a few waste oil tanks that are underground and no fuel is stored underground at any facility. Liquid deicer is stored in above-ground tanks with secondary containment.

\section{$\underline{\text { RECYCLING }}$}

INDOT has focused on creating source reduction and recycling infrastructure throughout its 250 State owned facilities. The Department has established recycling programs in all Districts and Divisions, developed programs specifically tailored to meet INDOT needs, and promoted information to employees to help reach goals set forth for the organization.

INDOT has long taken a proactive approach to Greening the Government activities associated with its performance in construction projects as well as internal facility applications. With the passing of Executive Order 99-07 (Greening the Government) in April of 1999, INDOT has made substantial progress toward reaching goals related to the Greening Plan and establishing the department as an environmental leader in the state.

INDOT has focused on creating source reduction and recycling infrastructure throughout its 200 State owned facilities. Through the infrastructure the department has established recycling programs in all Districts and Divisions, developed programs specifically tailored to meet INDOT

needs and promoted information to employees to help reach goals set forth for the organization.

\section{Project Description Summary:}

A. Coordination: Coordination of INDOT Greening Activities is accomplished through a system of appointed recycling coordinators and dedicated INDOT employees. The structure is set up in the following hierarchy: INDOT Recycling Coordinator, Division and District Recycling Coordinators, INDOT Facility Contacts and INDOT Employees. Meetings to discuss current program status, current projects and upcoming projects occur on a quarterly basis with the District and Division Recycling Coordinators. This information is utilized to expand source reduction and recycling opportunities throughout INDOT. 
B. Education: Education of INDOT personnel is accomplished in several fashions. Education methods include the following tools as a means to promote Greening activities:

District and Division Recycling Presentations, New Employee Orientation on Source Reduction and Recycling, Monthly Articles pertaining to Greening the Government Activities that are published in a monthly INDOT newsletter (Crossroads), an INDOT Website that covers issues related to Greening the Government, Energy Conservation and Recycling specifically related to the Indiana Department of Transportation. Furthermore, education is also accomplished through Greening the Government Updates that are provided by Indiana Department of Administration and distributed throughout the INDOT Recycling Infrastructure.

C. Programs: INDOT has developed several programs related to the promotion of Greening the Government Activities. These programs include the Most Outstanding Recycler Award, which is a monthly recognition program at INDOT promoted through Crossroads. A "Clean Your Files Day" Program specifically tailored to INDOT. The INDOT Recycling Trivia Question game promoted through the Crossroads. INDOT District and Division Recycling Programs, the INDOT Conservation Program and the INDOT waste diversion contracts. The waste diversion contracts involve all materials outside of traditional municipal solid waste (MSW). These materials include tires, shop waste, light bulbs, household and automotive batteries, PCB and Non-PCB containing ballasts and all mercury containing devices.

D. Promotional Activities: INDOT Recycling Mascot- Roady Recycler was created as the spokesperson for the INDOT Greening the Government Program. Roady has been utilized to promote INDOT Greening the Government Activities. INDOT also rewards individuals with Recycled content prizes to help promote awareness of Greening the Government programs as well as internal INDOT Programs. All promotional prizes that are awarded to INDOT staff are constructed of recycled content materials. The promotional prizes are awarded during District and Division Recycling presentations, New Employee Orientation presentations, submitting the correct answer to the INDOT Recycling Trivia Game and as a prize for being awarded as INDOT's Most Outstanding Recycler.

\section{Innovation Summary:}

The INDOT Greening the Government program is inclusive of all areas to provide effective education and promotion of all programs and opportunities available to INDOT personnel. Employees, both current and new are provided information on a monthly basis regarding source reduction and recycling opportunities. INDOT personnel have the opportunity to participate in recycling programs at INDOT facilities as well as participate in annual source reduction and recycling opportunities provided by INDOT and other state agencies.

INDOT recycling programs include materials such as office paper, newspaper, aluminum and steel, glass bottles, plastics \#1 and \#2, cardboard, magazines, paperboard, automotive and household batteries, CD's, computer discs, motor oil, transmission fluid, hydraulic fluid, power steering fluid, antifreeze, oil filters, 
mineral spirits, oil absorbents, paint, light bulbs, $\mathrm{PCB}$ and Non-PCB containing ballasts, mercury containing devices, toner cartridges, concrete and asphalt.

INDOT awards individuals for their efforts related to recycling through the Most Outstanding Recycler award program on a monthly basis. Awards are given to individuals that show outstanding effort related to source reduction and recycling. Single and/or multiple award recipients are recognized each month for their efforts. Their names and description as to why they received the award are printed in the monthly Crossroads newsletter.

INDOT focuses on the use of special waste materials for INDOT applications in construction projects. They include but are not limited to tire scraps, crushed glass bottles, fly ash and foundry sand. Projects utilizing waste tire scraps have been completed in the INDOT LaPorte District and projects utilizing crushed glass bottles have been completed in the INDOT Vincennes District. Studies of the current projects are currently underway. Fly Ash and Foundry Sand projects are currently under development and are projected to occur in the southern portion of Indiana.

INDOT has also focused efforts on pollution prevention through several programs that are very innovative to the state. They include the Alternative Work Schedule (AWS) where INDOT employees are allowed to work fewer days during the pay period, which in turn reduces vehicle pollution, congestion and potential traffic accidents.

INDOT utilizes teleconferencing technology as another means to reduce the amount of potential pollution from State vehicles. Through teleconferencing as well as three-way calling INDOT has helped eliminate the need to travel to a specific location and in turn reduce the amount of potential pollution created through vehicle emissions. This technology has also helped INDOT become much more efficient in normal daily operations and employee efficiency.

Furthermore, INDOT has adopted the Federal Policy of purchasing Flexible Fueled Vehicles (both cars and light trucks) which allows vehicles to operate on both regular gasoline and ethanol. Through the use of the corn based Ethanol fuels, INDOT will help eliminate potential smog forming emissions that are created through consumption of regular gasoline.

As a final effort to reduce pollution INDOT promotes the efficient use of the INDOT motor pool by carpooling to meetings when possible. This helps eliminate emissions from vehicles as well as saves on wear and tear of the State Vehicles and reduces fuel consumption.

\section{Measurable Results Summary:}

Results related to INDOT's comprehensive program have been very positive in all Greening the Government/Source Reduction and Recycling Programs. The most positive measurable result has been the education of INDOT employees related to 
the monthly INDOT Crossroads article and the INDOT source reduction and recycling web site.

The INDOT Crossroads Article and associated material has helped provide a great deal of information to INDOT employees on INDOT source reduction and recycling programs as well as other Government agency programs on various subjects. The INDOT web site has provided information on contacts within INDOT's Central Office and in all INDOT Districts to help with the development of INDOT statewide programs associated with source reduction and recycling.

Enthusiasm of INDOT employees has also increased related to the source reduction and recycling activities. This being in response to the various programs and opportunities INDOT have provided to its employees. This in turn has significantly increased the amount of participation in the various INDOT recycling programs/opportunities.

Other measurable results have come from the number of different and distinct materials that INDOT has targeted for its source reduction and recycling programs. More and more programs are developed within INDOT each year and since the number of programs have increased as well as the number of materials collected for recycling the amount of materials recycled at INDOT has increased significantly.

Because INDOT is a large state agency tracking of specific materials cannot be accomplished through the programs unless additional equipment, manpower as well as money are increased to help with the record keeping purposes in approximately 200 state owned facilities. For 2001, INDOT recycled the following quantities of materials (2001 figures have yet to be completely compiled, certain materials could not be included):

$>$ Waste Oil and Associated Material: 50,000+ gallons

$>$ Over 5,000 bulbs: fluorescent, traffic, headlight, high-pressure sodium, etc.

$>$ Approximately $150 \mathrm{lbs}$. of PCB and Non-PCB containing ballasts

$>$ Over 1,000 lbs. of household batteries

$>$ Over 1,000 combined tons of office paper, newspaper, aluminum and steel, glass bottles, plastics \#1 and \#2, cardboard, magazines and paperboard (This includes all materials recovered in the Marion County program as well as INDOT facilities located throughout the state).

$>$ Approximately 2,500 gallons of waste antifreeze.

$>120$ pounds of PCB and Non-PCB containing ballasts.

$>145$ 55-gallon barrels of used oil filters.

$>$ Approximately 10,000 INDOT and abandoned waste tires as well as over 200 tons of scrap tires recovered from INDOT roadways.

$>1,200$ gallons of mineral spirits.

$>$ Approximately 1 million tons of milled asphalt and crushed concrete.

IV. Comprehensiveness:

INDOT's Greening Program is very comprehensive in relation to education. Education has become the main focus of the INDOT Greening hierarchy and is 
accomplished through several methods. The most significant is the chain of INDOT Recycling Coordinators throughout the INDOT Divisions and Districts as well as the INDOT facilities. The Recycling Coordinators are the main link to information sources, program development as well as communication with the INDOT employees.

The educational system established in the INDOT Greening program is that of a reward-based system. Rewarding employees for both their knowledge as well as their efforts. This includes rewarding employees with recycled content prizes related to the INDOT Crossroads recycling trivia game, the Most Outstanding Recycler award and recycled content prizes given out at INDO'T District and Division recycling presentations.

The educational material conveyed through the INDOT presentations, Crossroads articles, the INDOT website and electronic communication allow INDOT employees to become aware of Greening activities throughout the department. As well as learn about recycled content products and companies that produce the recycled content products.

Presentations, whether Division, District or New Employee Orientation are very extensive covering all aspects of programs specific to a particular area. The monthly Crossroads article covers information relevant to INDOT Greening the Government Programs such as household battery recycling as well as special INDOT Greening Projects such as the use of shredded tires as road base or crushed glass bottles utilized as a B-Borrow substitute in an INDOT pipe backfill project.

INDOT's Intranet Home Page is another significant source of information regarding Greening Activities. The website, which is located at

\section{http://is-100141.indot.state.in.us:8080/testsite/}

contains very valuable information that is accessible to all INDOT employees that have Internet access on their computer. Relevant Greening the Government/INDOT Conservation Effort's information can be found under Employee Information on the Home Page. Specific information covered on the web site includes the INDOT Energy Conservation Policy, INDOT Division and District Recycling Coordinators, INDOT's Clean Your Files Day Program (CYFD), INDOT's Most Outstanding Recycler List, INDOT Crossroads Article, INDOT Recycling Trivia Question Information, INDOT's Recycling Trivia Question Winner List and specific information related to INDOT waste diversion quantities.

INDOT's internal recycling program is leading in the number of separate waste streams targeted for reuse and recycling. Approximately 25 separate and unique materials are collected through the current programs operating throughout INDOT. Collection, transportation and processing of the various materials are completed internally by INDOT personnel and equipment or commercially by vendors contracting with INDOT or through local county solid waste management districts. Review of the separate types of materials collected in the program and associated quantities can be viewed in the Section III of the Nomination Questions above. 
INDOT's Pollution Prevention efforts are also paramount in relation to Greening the Government. Review of Section II, Innovation Summary, provides a great deal of information regarding Pollution Prevention efforts at INDOT specifically related to Transportation.

Other areas where INDOT has focused on Pollution Prevention is through the reuse of more than 1 million tons of milled concrete and asphalt in new road construction projects annually. INDOT has also introduced a Filtered Part Washing System into the INDOT maintenance shop environment to help eliminate the production of spent mineral spirits. And finally, INDOT has participated in the closed loop re-refined oil purchasing and recycling program since the inception of the program in 1999. In 2001 , this program helped INDOT recycle over 50,000 gallons of waste oil and related products.

\section{Measurable Goals}

Measurable goals, which are required for each minimum control measure, are intended to gauge permit compliance and program effectiveness. At a minimum, the measurable goal for this program would be to provide pollution prevention at INDOT operation and maintenance facilities and for road side maintenance/ good housekeeping.

The following are the measurable goals for INDOT's pollution prevention at INDOT operation and maintenance facilities and for road side maintenance/ good housekeeping program for the initial five (5) year permit period.

\begin{tabular}{|c|c|}
\hline Target Date & Activity \\
\hline $\begin{array}{l}\text { Year } 1 \\
\text { November } 1,2003 \text { to } \\
\text { October } 31,2004\end{array}$ & $\begin{array}{l}\text { - Form a Field Maintenance and Operations Task Force to } \\
\text { meet regularly and develop an Environmental } \\
\text { Management System (EMS), tying all the standard } \\
\text { operating procedures into one system with measurable } \\
\text { results, begin by October } 1,2004 \text {. } \\
\text { - Evaluate whether added environmental measures are } \\
\text { required for existing maintenance and operation } \\
\text { procedures, begin by October 1,2004. } \\
\text { See APPENDIX C }\end{array}$ \\
\hline $\begin{array}{l}\text { Year } 2 \\
\text { November } 1,2004 \text { to } \\
\text { October } 31,2005\end{array}$ & $\begin{array}{l}\text { - Field Maintenance and Operations Task Force will } \\
\text { review all existing field maintenance and operations } \\
\text { procedures and evaluate these procedures for } \\
\text { compliance with storm water regulations and pollution } \\
\text { reduction, on-going through } 2005 \text {. } \\
\text { - Task Force will determine if INDOT Maintenance and } \\
\text { Operations Facilities will become ISO } 14001 \text { certified. }\end{array}$ \\
\hline $\begin{array}{l}\text { Year } 3 \\
\text { November } 1,2005 \text { to } \\
\text { October } 31,2006 \\
\end{array}$ & $\begin{array}{l}\text { - Field Maintenance and Operations Task Force to meet } \\
\text { regularly and develop an Environmental Management } \\
\text { System, on-going through } 2006 \text {. }\end{array}$ \\
\hline
\end{tabular}




\begin{tabular}{|c|c|}
\hline & $\begin{array}{l}\text { - Develop an annual training program for INDOT field } \\
\text { employees to provide added environmental awareness } \\
\text { and measures to field operations activities, begin by } \\
\text { October } 1,2006 \text {. }\end{array}$ \\
\hline $\begin{array}{l}\text { Year } 4 \\
\text { November } 1,2006 \text { to } \\
\text { October } 31,2007\end{array}$ & $\begin{array}{l}\text { Field Maintenance and Operations Task Force to meet } \\
\text { regularly and develop an Environmental Management } \\
\text { System, on-going through } 2007 \text {. } \\
\text { - Implement annual training of INDOT field employees to } \\
\text { provide added environmental awareness and measures to } \\
\text { field operations activities, begin training October } 1 \text {, } \\
\text { 2007. }\end{array}$ \\
\hline $\begin{array}{l}\text { Year } 5 \\
\text { November } 1,2007 \text { to } \\
\text { October } 31,2008\end{array}$ & $\begin{array}{l}\text { - Field Maintenance and Operations Task Force to meet } \\
\text { regularly and develop an Environmental Management } \\
\text { System, on-going through } 2008 \text {. } \\
\text { Evaluate the field employees training for effectiveness, } \\
\text { by October } 1,2008 \text {. } \\
\text { - INDOT Environmental Management System (EMS) for } \\
\text { Maintenance and Operations in place by October } 1 \text {, } \\
\text { 2008. }\end{array}$ \\
\hline
\end{tabular}




\begin{tabular}{|c|c|c|c|c|c|c|c|c|c|c|c|c|}
\hline \multicolumn{13}{|c|}{ Crawfordsville District } \\
\hline ID \# & $\begin{array}{c}\text { High- } \\
\text { way }\end{array}$ & $\begin{array}{l}\text { Co. } \\
\text { No. }\end{array}$ & $\begin{array}{l}\text { Water } \\
\text { Body }\end{array}$ & Date & Time & $\begin{array}{c}\text { Temp } \\
\left(\mathrm{C}^{\circ}\right)\end{array}$ & $\begin{array}{c}\text { Cond. } \\
(\mu \mathrm{S} / \mathrm{cm})\end{array}$ & $\begin{array}{c}\mathrm{DO} \\
(\mathrm{mg} / \mathrm{L})\end{array}$ & $\begin{array}{l}\mathrm{pH} \\
(\%)\end{array}$ & $\begin{array}{l}\text { ORP } \\
(\mathrm{mV})\end{array}$ & $\begin{array}{c}\text { Turb. } \\
\text { (NTU) }\end{array}$ & $\begin{array}{l}\text { Chlor. } \\
\text { (mg/L) }\end{array}$ \\
\hline \multirow[t]{2}{*}{1} & SR 26 & 79 & Wildcat & $7 / 15 / 03$ & $8: 25$ & 21.3 & 547 & 8.18 & 8.10 & 135.6 & 33.8 & \\
\hline & & & & & $8: 27$ & 21.29 & 548 & 8.08 & 8.08 & 144.9 & 39.2 & \\
\hline \multirow{3}{*}{2} & תח & & Wlidnat & & & & & & & & & \\
\hline & SR 26 & 79 & Wildcat & $7 / 15 / 03$ & $9: 45$ & 19.99 & 557 & 8.49 & 8.02 & 187.9 & 92.1 & \\
\hline & & & & & 9:47 & 20 & 556 & 8.43 & 8.02 & 189.2 & 102.1 & \\
\hline \multirow{2}{*}{3} & SR 38 & 79 & Wildcat & $7 / 15 / 03$ & $10: 11$ & 20.87 & 545 & 8.31 & 8.10 & 206.5 & $\overline{26.4}$ & \\
\hline & & & & & $10: 13$ & 20.87 & 545 & 8.14 & 8.10 & 206.3 & 26.6 & \\
\hline & & & & & & & & & & & & \\
\hline \multirow[t]{2}{*}{31} & US 41 & 86 & Fall & $7 / 15 / 03$ & $14: 57$ & 19.89 & 477 & 9.35 & 8.02 & 195.4 & 51.2 & \\
\hline & & & & & $14: 59$ & 19.91 & 477 & 9.12 & 8.01 & 196.4 & 50.4 & \\
\hline & & & & & & & & & & & & \\
\hline \multirow[t]{2}{*}{32} & SR 55 & 86 & Big Pine & $7 / 15 / 03$ & $15: 11$ & 21.82 & 522 & 8.57 & 8.16 & 215.1 & 116.5 & \\
\hline & & & & & $15: 13$ & 21.81 & 522 & 8.41 & 8.14 & 216.0 & 117.2 & \\
\hline & & & & & & & & & & & & \\
\hline \multirow[t]{2}{*}{33} & SR 26 & 86 & Mud Pine & $7 / 15 / 03$ & $14: 05$ & 20.9 & 538 & 8.85 & 7.98 & 213.0 & 38.2 & \\
\hline & & & & & $14: 07$ & 20.9 & 536 & 8.65 & 7.98 & 214.1 & 39.4 & \\
\hline & & & & & & & & & & & & \\
\hline \multirow{2}{*}{38} & $1-74$ & 54 & Sugar & $7 / 14 / 03$ & $10: 00$ & 20.82 & 538 & 9.01 & 8.11 & 149.8 & 20.5 & \\
\hline & & & & & $10: 02$ & 20.84 & 537 & 8.89 & 8.11 & 168.3 & 26.5 & \\
\hline & & & & & & & & & & & & \\
\hline \multirow[t]{2}{*}{39} & US 231 & 54 & Sugar & $7 / 14 / 03$ & $10: 29$ & 20.85 & 541 & 9.10 & 8.13 & 157.9 & 24.3 & \\
\hline & & & & & $10: 31$ & 20.86 & 542 & 8.91 & 8.12 & \begin{tabular}{|l|}
172.0 \\
\end{tabular} & 28.0 & \\
\hline & & & & & & & & & & & & \\
\hline \multirow[t]{2}{*}{40} & US 136 & 54 & Sugar & $7 / 14 / 03$ & $10: 47$ & 21.03 & 547 & 9.03 & 8.12 & 172.5 & 18.4 & \\
\hline & & & & & $10: 49$ & 21.06 & 547 & 8.90 & 8.12 & 180.5 & 18.4 & \\
\hline & & & & & & & & & & & & \\
\hline \multirow[t]{2}{*}{41} & SR 32 & 54 & Sugar & $7 / 14 / 03$ & $11: 16$ & 21.26 & 558 & 9.01 & 8.12 & 170.2 & 20.2 & \\
\hline & & & & & $11: 18$ & 21.27 & 558 & 8.80 & 8.12 & 176.3 & 19.7 & \\
\hline \multirow{2}{*}{42} & SR 234 & 54 & Indian & $7 / 14 / 03$ & $11: 45$ & 21.67 & 556 & 9.12 & 8.17 & 181.6 & 294 & \\
\hline & & & & & $11: 47$ & 21.68 & 556 & 8.95 & 8.17 & \begin{tabular}{|l|}
183.8 \\
183.0
\end{tabular} & $\frac{20.4}{30.8}$ & \\
\hline & & & & & & & & & & & & \\
\hline \multirow[t]{2}{*}{45} & US 41 & 61 & Sugar & $7 / 14 / 03$ & $11: 28$ & 22.37 & 546 & 8.67 & 8.22 & 188.0 & 26.5 & \\
\hline & & & & & $11: 30$ & 22.38 & 546 & 8.61 & 8.22 & \begin{tabular}{|l|}
187.9 \\
\end{tabular} & 26.5 & \\
\hline & & & & & & & & & & & & \\
\hline \multirow[t]{2}{*}{46} & US 41 & 61 & Sugar Mill & $7 / 14 / 03$ & $12: 20$ & 23.79 & 561 & 9.29 & 8.34 & 171.6 & 4.6 & \\
\hline & & & & & $12: 22$ & 23.78 & 561 & 9.18 & 8.34 & \begin{tabular}{|l|}
174.4 \\
\end{tabular} & 4.6 & \\
\hline & & & & & & & & & & & & \\
\hline \multirow[t]{2}{*}{91} & \begin{tabular}{|l|} 
SR 352 \\
\end{tabular} & 4 & Mud Pine & $7 / 15 / 03$ & $14: 27$ & 20.03 & 529 & 6.90 & 7.08 & 215.5 & 24.4 & \\
\hline & & & & & $14: 29$ & 20.03 & 529 & 6.52 & 7.07 & \begin{tabular}{|l|}
215.6 \\
\end{tabular} & 24.5 & \\
\hline \multirow[t]{2}{*}{92} & SR 26 & 86 & Big Pine & $7 / 15 / 03$ & $13: 50$ & 20.92 & 573 & 8.04 & 7.80 & \begin{tabular}{|l|}
198.2 \\
\end{tabular} & 35.7 & \\
\hline & & & & & $13: 52$ & 20.93 & 573 & 7.76 & 7.80 & \begin{tabular}{|l|}
202.7 \\
\end{tabular} & 35.7 & \\
\hline & & & & & & & & & & & & \\
\hline \multirow[t]{3}{*}{93} & US 36 & 67 & Big Walnut & $7 / 15 / 03$ & $14: 14$ & 23.02 & 592 & 9.06 & 8.22 & 168.9 & 9.8 & \\
\hline & & & & & $14: 16$ & 23.04 & 592 & 8.94 & 8.21 & 175.3 & 9.7 & \\
\hline & & & & & & & & & & & & \\
\hline
\end{tabular}




\begin{tabular}{|c|c|c|c|c|c|c|c|c|c|c|c|c|}
\hline \multicolumn{3}{|c|}{ LaPorte District } & \multirow[b]{2}{*}{$\begin{array}{l}\text { Water } \\
\text { Body }\end{array}$} & \multirow[b]{2}{*}{ Date } & \multirow[b]{2}{*}{ Time } & \multirow[b]{2}{*}{$\begin{array}{c}\text { Temp } \\
\left(\mathrm{C}^{\circ}\right)\end{array}$} & \multirow[b]{2}{*}{$\begin{array}{c}\text { Cond. } \\
(\mu \mathrm{S} / \mathrm{cm})\end{array}$} & \multirow[b]{2}{*}{$\begin{array}{c}\mathrm{DO} \\
(\mathrm{mg} / \mathrm{L})\end{array}$} & \multirow[b]{2}{*}{$\begin{array}{l}\mathrm{pH} \\
(\%)\end{array}$} & \multirow[b]{2}{*}{$\begin{array}{l}\text { ORP } \\
(\mathrm{mV})\end{array}$} & \multirow[b]{2}{*}{$\begin{array}{l}\text { Turb. } \\
\text { (NTU) }\end{array}$} & \multirow[b]{2}{*}{$\begin{array}{l}\text { Chlor. } \\
\text { (mg/L) }\end{array}$} \\
\hline ID \# & $\begin{array}{c}\text { High- } \\
\text { way }\end{array}$ & $\begin{array}{l}\text { Co. } \\
\text { No. }\end{array}$ & & & & & & & & & & \\
\hline \multirow[t]{3}{*}{14} & SR 29 & 8 & Wildcat & $7 / 15 / 03$ & $11: 29$ & 21.69 & 456 & 8.00 & 7.88 & 209.8 & 114.2 & \\
\hline & & & & & $11: 31$ & 21.6 & 456 & 7.59 & 7.89 & \begin{tabular}{|l|}
208.4 \\
\end{tabular} & 115.6 & \\
\hline & & & & & & & & & & & & \\
\hline \multirow[t]{2}{*}{13} & SR 75 & 8 & Wildcat & $7 / 15 / 03$ & $11: 07$ & 22.02 & 465 & 7.96 & 7.92 & 197.9 & 133.0 & \\
\hline & & & & & $11: 09$ & 22.01 & 465 & 7.64 & 7.91 & 200.2 & 131.5 & \\
\hline & & & & & & & & & & & & \\
\hline \multirow[t]{2}{*}{6} & US 421 & 8 & Wildcat & $7 / 15 / 03$ & $10: 46$ & 20.12 & 530 & 8.04 & 7.82 & 216.5 & 61.2 & \\
\hline & & & & & $10: 48$ & 20.12 & 530 & 7.80 & 7.81 & 215.6 & 62.6 & \\
\hline & & & & & & & & & & & & \\
\hline \multirow{2}{*}{24} & $1-94$ & 64 & Salt & $7 / 23 / 03$ & $11: 54$ & 19.92 & 606 & 7.23 & 7.75 & 133.6 & 37.5 & \\
\hline & & & & & $11: 56$ & 19.92 & 606 & 7.07 & 7.75 & 145.5 & 37.5 & \\
\hline & & & & & & & & & & & & \\
\hline \multirow[t]{2}{*}{25} & SR 149 & 64 & Lit. Calumet & $7 / 23 / 03$ & $15: 38$ & 19.87 & 730 & 8.47 & 7.91 & 160.9 & 28.2 & \\
\hline & & & & & $15: 40$ & 19.88 & 730 & 8.07 & 7.92 & \begin{tabular}{|l|}
171.8 \\
\end{tabular} & 28.4 & \\
\hline & & & & & & & & & & & & \\
\hline \multirow[t]{2}{*}{87} & St. Pk. & 64 & L. Michigan & $7 / 23 / 03$ & \multicolumn{4}{|c|}{ road run off - no water to test } & & & & \\
\hline & & & & & & & & & & & & \\
\hline & & & & & & & & & & & & \\
\hline 28 & US 12 & 64 & Beverly Sh. & $7 / 23 / 03$ & $13: 34$ & 16.51 & 256 & 6.87 & 7.50 & 58.2 & 4.2 & \\
\hline & & & & & $13: 36$ & 16.51 & 256 & 6.52 & 7.45 & 53.0 & 4.2 & \\
\hline & & & & & & & & & & & & \\
\hline 29 & US 12 & 64 & Beverly Sh. & $7 / 23 / 03$ & water t & oo shall & ow, 2" dee & o, cannot & test & & & \\
\hline & & & & & & & & & & & & \\
\hline & & & & & & & & & & & & \\
\hline 90 & US 12 & 64 & Brown D. & $7 / 23 / 03$ & dry & & & & & & & \\
\hline & & & & & & & & & & & & \\
\hline & & & & & & & & & & & & \\
\hline 30 & US 12 & 64 & \begin{tabular}{|l|} 
Kintzele D. \\
\end{tabular} & $7 / 23 / 03$ & $13: 55$ & 20.17 & 925 & 8.45 & 7.65 & 139.1 & 11.5 & \\
\hline & & & & & $13: 57$ & 20.16 & 925 & 8.35 & 7.65 & 135.4 & 11.3 & \\
\hline & & & & & & & & & & & & \\
\hline 85 & US 12 & 64 & Long Lake & $7 / 23 / 03$ & no poir & it sourc & e discharg & & & & & \\
\hline & & & & & & & & & & & & \\
\hline & & & & & & & & & & & & \\
\hline 27 & US 12 & 64 & Munson D. & $7 / 23 / 03$ & $13: 15$ & 18.42 & 1106 & 8.77 & 7.94 & 187.3 & 45.3 & \\
\hline & & & & & $13: 17$ & 18.43 & 1106 & 8.62 & 7.93 & 177.3 & 30.4 & \\
\hline & & & & & & & & & & & & \\
\hline 88 & US 20 & 64 & Beverly Sh. & $7 / 23 / 03$ & dry & & & & & & & \\
\hline & & & & & & & & & & & & \\
\hline & & & & & & & & & & & & \\
\hline 89 & US 20 & 64 & Beverly Sh. & $7 / 23 / 03$ & dry & & & & & & & \\
\hline & & & & & & & & & & & & \\
\hline & & & & & & & & & & & & \\
\hline 86 & US 20 & 64 & EB Lit. Cal. & $7 / 23 / 03$ & $12: 31$ & 20.40 & 381 & 5.99 & 7.43 & 190.6 & 5.7 & \\
\hline & & & & & $12: 33$ & 20.41 & 381 & 5.79 & 7.40 & 191.2 & 5.8 & \\
\hline & & & & & & & & & & & & \\
\hline 26 & US 20 & 64 & Lit. Calumet & $7 / 23 / 03$ & $\frac{12: 16}{12: 18}$ & $\begin{array}{l}19.46 \\
19.46\end{array}$ & $\frac{736}{736}$ & $\frac{8.13}{8.17}$ & $\frac{7.91}{7.90}$ & \begin{tabular}{|l|}
196.8 \\
198.3 \\
\end{tabular} & $\frac{25.6}{25.9}$ & \\
\hline & & & & & & & & & & & & \\
\hline
\end{tabular}




\begin{tabular}{|c|c|c|c|c|c|c|c|c|c|c|c|c|}
\hline 23 & US 20 & 64 & Salt & $7 / 23 / 03$ & $12: 05$ & 19.93 & 610 & 7.40 & 7.76 & 139.3 & 35.6 & \\
\hline & & & & & $12: 07$ & 19.93 & 610 & 7.11 & 7.75 & 146.8 & 35.4 & \\
\hline & & & & & & & & & & & & \\
\hline \multicolumn{13}{|c|}{ Greenfield District } \\
\hline ID \# & $\begin{array}{l}\text { High- } \\
\text { way }\end{array}$ & $\begin{array}{l}\text { Co. } \\
\text { No. }\end{array}$ & $\begin{array}{l}\text { Water } \\
\text { Body }\end{array}$ & Date & Time & $\begin{array}{c}\text { Temp } \\
\left(\mathrm{C}^{\circ}\right)\end{array}$ & $\begin{array}{c}\text { Cond. } \\
(\mu \mathrm{S} / \mathrm{cm})\end{array}$ & $\begin{array}{c}\mathrm{DO} \\
(\mathrm{mg} / \mathrm{L})\end{array}$ & $\begin{array}{l}\mathrm{pH} \\
(\%)\end{array}$ & $\begin{array}{l}\text { ORP } \\
(\mathrm{mV})\end{array}$ & $\begin{array}{l}\text { Turb. } \\
\text { (NTU) }\end{array}$ & $\begin{array}{l}\text { Chlor. } \\
\text { (mg/L) }\end{array}$ \\
\hline \multirow[t]{3}{*}{100} & SR 121 & 24 & Whitewater & $7 / 31 / 03$ & $9: 32$ & 20.13 & 644 & 11.37 & 8.21 & 61.1 & 4.2 & \\
\hline & & & & & $9: 34$ & 20.13 & 644 & 11.25 & 8.21 & 64.0 & 4.2 & \\
\hline & & & & & & & & & & & & \\
\hline \multirow[t]{3}{*}{11} & SR 22 & 34 & Wildcat & $7 / 15 / 03$ & $11: 39$ & 21.29 & 418 & 8.06 & 7.85 & 212.5 & 216.8 & \\
\hline & & & & & $11: 41$ & 21.29 & 417 & 7.63 & 7.84 & 213.3 & 223.9 & \\
\hline & & & & & & & & & & & & \\
\hline \multicolumn{13}{|c|}{ Seymour District } \\
\hline ID \# & $\begin{array}{l}\text { High- } \\
\text { way }\end{array}$ & $\begin{array}{l}\text { Co. } \\
\text { No. }\end{array}$ & $\begin{array}{l}\text { Water } \\
\text { Body }\end{array}$ & Date & Time & $\begin{array}{c}\text { Temp } \\
\left(\mathrm{C}^{0}\right)\end{array}$ & $\begin{array}{c}\text { Cond. } \\
(\mu \mathrm{S} / \mathrm{cm})\end{array}$ & $\begin{array}{c}\mathrm{DO} \\
(\mathrm{mg} / \mathrm{L})\end{array}$ & $\begin{array}{l}\mathrm{pH} \\
(\%)\end{array}$ & $\begin{array}{l}\text { ORP } \\
(\mathrm{mV})\end{array}$ & $\begin{array}{l}\text { Turb. } \\
\text { (NTU) }\end{array}$ & $\begin{array}{l}\text { Chlor. } \\
\text { (mg/L) }\end{array}$ \\
\hline 96 & SR 62 & 13 & Blue R. & $8 / 12 / 03$ & \multicolumn{4}{|c|}{ too steep, dense filtration } & & & & \\
\hline & & & & & & & & & & & & \\
\hline & & & & & & & & & & & & \\
\hline 97 & SR 62 & 13 & Blue R. & $8 / 12 / 03$ & \multicolumn{4}{|c|}{ unsafe, steep hill, dense filtration } & & & & \\
\hline \multirow{3}{*}{\begin{tabular}{|l|} 
\\
\\
55 \\
\\
\end{tabular}} & & & & & & & & & & & & \\
\hline & SR 1 & 24 & Whitewater & $7 / 31 / 03$ & $11: 01$ & 21.10 & 582 & 10.97 & 8.19 & 101.6 & 4.2 & \\
\hline & & & & & $11: 03$ & 21.10 & 582 & 10.72 & 8.18 & 100.4 & 4.4 & \\
\hline & & & & & & & & & & & & \\
\hline \multirow[t]{3}{*}{54} & US 52 & 24 & Whitewater & $7 / 31 / 03$ & 9:45 & 20.41 & 637 & 11.63 & 8.24 & 86.3 & 5.2 & \\
\hline & & & & & $9: 47$ & 20.41 & 637 & 11.51 & 8.24 & 85.1 & 5.1 & \\
\hline & & & & & & & & & & & & \\
\hline \multirow[t]{2}{*}{101} & US 52 & 24 & Whitewater & $7 / 31 / 03$ & $10: 24$ & 21.84 & 602 & 9.69 & 8.28 & 114.1 & 31.7 & \\
\hline & & & & & $10: 26$ & 20.84 & 602 & 9.29 & 8.27 & 110.6 & 30.8 & \\
\hline \multirow[t]{3}{*}{102} & US 52 & 24 & Whitewater & $7 / 31 / 03$ & $10: 37$ & 21.52 & 605 & 11.49 & 8.24 & 106.1 & 4.5 & \\
\hline & & & & & $10: 39$ & 21.52 & 605 & 11.44 & 8.23 & 99.4 & 4.3 & \\
\hline & & & & & & & & & & & & \\
\hline \multirow[t]{3}{*}{103} & US 52 & 24 & Whitewater & $7 / 31 / 03$ & \multicolumn{7}{|c|}{ impractical, unsafe, dangerous curve, terrain too steep, } & \\
\hline & & & & & \multicolumn{3}{|c|}{ dense filtration } & & & & & \\
\hline & & & & & & & & & & & & \\
\hline \multirow[t]{3}{*}{104} & US 52 & 24 & Whitewater & $7 / 31 / 03$ & \multicolumn{7}{|c|}{ impractical, unsafe, dangerous curve, terrain too steep } & \\
\hline & & & & & \multicolumn{3}{|c|}{ dense filtration } & & & & & \\
\hline & & & & & & & & & & & & \\
\hline \multirow[t]{3}{*}{105} & US 52 & 24 & Whitewater & $7 / 31 / 03$ & \multicolumn{8}{|c|}{ impractical, unsafe, dangerous, too steep, dense filtration } \\
\hline & & & & & & & & & & & & \\
\hline & & & & & & & & & & & & \\
\hline \multirow[t]{2}{*}{106} & US 52 & 24 & Whitewater & $7 / 31 / 03$ & \multicolumn{6}{|c|}{ impractical, unsafe, dense vegetation/filtration } & & \\
\hline & & & & & & & & & & & & \\
\hline \begin{tabular}{|l|}
107 \\
\end{tabular} & US 52 & 24 & Whitewater & 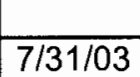 & $11: 20$ & 21.37 & 581 & 11.07 & 8.23 & 107.4 & 28.1 & \\
\hline & & & & & $11: 22$ & 21.38 & 581 & 10.98 & 8.22 & \begin{tabular}{|l|}
103.2 \\
\end{tabular} & 29.5 & \\
\hline & & & & & & & & & & & & \\
\hline 82 & $\mathrm{I}-64$ & 31 & Blue R. & $8 / 12 / 03$ & \begin{tabular}{|l|}
$11: 23$ \\
$11 \cdot 25$
\end{tabular} & $\frac{23.44}{23.46}$ & 445 & $\frac{11.07}{1023}$ & $\begin{array}{l}7.99 \\
798\end{array}$ & \begin{tabular}{|l|}
69.3 \\
73.1
\end{tabular} & $\begin{array}{l}4.7 \\
17\end{array}$ & \\
\hline & & & & & & 23.40 & 444 & 10.23 & 7.98 & 73.1 & 4.7 & \\
\hline
\end{tabular}




\begin{tabular}{|c|c|c|c|c|c|c|c|c|c|c|c|c|}
\hline & & & & & & & & & & & & \\
\hline 83 & SR 62 & 31 & Blue R. & $8 / 12 / 03$ & $11: 47$ & 22.89 & 463 & 10.72 & 7.88 & 115.7 & 4.1 & \\
\hline & & & & & $11: 49$ & 22.87 & 463 & 10.32 & 7.85 & 115.2 & 4.3 & \\
\hline & & & & & & & & & & & & \\
\hline 94 & SR 62 & 31 & Blue $R$. & $8 / 12 / 03$ & \multicolumn{4}{|c|}{ too steep, dense filtration } & & & & \\
\hline & & & & & & & & & & & & \\
\hline & & & & & & & & & & & & \\
\hline 95 & SR 62 & 31 & Blue R. & $8 / 12 / 03$ & \multicolumn{4}{|c|}{ too steep, dense filtration } & & & & \\
\hline & & & & & \begin{tabular}{l|l} 
\\
\end{tabular} & 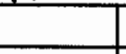 & 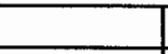 & & & & & \\
\hline & & & & & & & & & & & & \\
\hline 74 & SR 64 & 31 & Blue R. & $8 / 12 / 03$ & $10: 47$ & 21.49 & 454 & 10.77 & 8.11 & 45.8 & 10.1 & \\
\hline & & & & & $10: 49$ & 21.49 & 454 & 9.60 & 8.10 & 51.6 & 9.9 & \\
\hline & & & & & & & & & & & & \\
\hline 73 & SR 135 & 88 & Blue R. S. & $8 / 12 / 03$ & $9: 57$ & 21.32 & 270 & 8.11 & 7.62 & 37.6 & 10.8 & \\
\hline & & & & & $9: 59$ & 21.29 & 270 & 7.54 & 7.58 & 44.2 & 10.1 & \\
\hline & & & & & & & & & & & & \\
\hline 65 & SR 60 & 88 & N. Fk. Lost & $8 / 11 / 03$ & dry & & & & & & & \\
\hline & & & & & & & & & & & & \\
\hline & & & & & & & & & & & & \\
\hline 66 & SR 60 & 88 & N. Fk. Lost & $8 / 11 / 03$ & dry & & & & & & & \\
\hline & & & & & & & & & & & & \\
\hline & & & & & & & & & & & & \\
\hline 72 & SR 150 & 88 & Blue R. & $8 / 12 / 03$ & $10: 15$ & 21.24 & 450 & 10.15 & 8.02 & 57.9 & 11.5 & \\
\hline & & & & & $10: 17$ & 21.24 & 450 & 9.66 & 8.02 & 62.7 & 11.4 & \\
\hline & & & & & & & & & & & & \\
\hline Vinc & ennes Dis & strict & & & & & & & & & & \\
\hline $\mathrm{D} \#$ & $\begin{array}{l}\text { High- } \\
\text { way }\end{array}$ & $\begin{array}{l}\text { Co. } \\
\text { No. }\end{array}$ & $\begin{array}{l}\text { Water } \\
\text { Body }\end{array}$ & Date & Time & $\begin{array}{c}\text { Temp } \\
\left(\mathrm{C}^{\circ}\right)\end{array}$ & $\begin{array}{c}\text { Cond. } \\
(\mu \mathrm{S} / \mathrm{cm})\end{array}$ & $\begin{array}{c}\mathrm{DO} \\
(\mathrm{mg} / \mathrm{L})\end{array}$ & $\begin{array}{l}\mathrm{pH} \\
(\%)\end{array}$ & $\begin{array}{l}\text { ORP } \\
(\mathrm{mV})\end{array}$ & $\begin{array}{c}\text { Turb. } \\
\text { (NTU) }\end{array}$ & $\begin{array}{l}\text { Chlor. } \\
\text { (mg/L) }\end{array}$ \\
\hline 68 & SR 337 & 59 & Lost R. & $8 / 11 / 03$ & $11: 59$ & 22.83 & 480 & 11.46 & 8.07 & 116.5 & 3.4 & \\
\hline & & & & & $12: 01$ & 22.81 & 480 & 11.43 & 8.06 & 116.9 & 3.6 & \\
\hline & & & & & & & & & & & & \\
\hline 69 & SR 337 & 59 & Stampers & $8 / 11 / 03$ & dry & & & & & & & \\
\hline & & & & & & & & & & & & \\
\hline & & & & & & & & & & & & \\
\hline 64 & SR 37 & 59 & Lost R. & $8 / 11 / 03$ & dry & & & & & & & \\
\hline & & & & & & & & & & & & \\
\hline & & & & & & & & & & & & \\
\hline 62 & SR 56 & 59 & Lost R. & $8 / 11 / 03$ & $13: 33$ & 19.99 & 558 & 8.89 & 7.88 & 48.6 & 15.4 & \\
\hline & & & & & $13: 35$ & 19.99 & 550 & 8.64 & 7.86 & 54.0 & 16.1 & \\
\hline & & & & & & & & & & & & \\
\hline 70 & SR 56 & 59 & Stampers & $8 / 11 / 03$ & $12: 20$ & 16.18 & 396 & 14.48 & 8.05 & \begin{tabular}{l|}
127.1 \\
\end{tabular} & 4.2 & \\
\hline & & & & & \begin{tabular}{|l|}
$12: 22$ \\
\end{tabular} & 16.19 & 415 & 14.49 & 8.04 & 125.5 & 4.2 & \\
\hline & & & & & & & & & & & & \\
\hline 71 & SR 56 & 59 & Wolf & $8 / 11 / 03$ & too sha & llow to & test & & & & & \\
\hline & & & & & & & & & & & & \\
\hline & & & & & & & & & & & & \\
\hline 67 & SR 60 & 59 & Carters. & $8 / 11 / 03$ & $11: 30$ & 19.03 & 536 & 10.53 & 8.04 & 80.7 & 3.7 & \\
\hline & & & & & $11: 32$ & 19.14 & 537 & 10.22 & 8.11 & 82.3 & 3.7 & \\
\hline & & & & & & & & & & & & \\
\hline 60 & US 150 & 59 & Lost R. & $8 / 11 / 03$ & 13:55 & 21.69 & 572 & 7.49 & 7.83 & 137.8 & 64.3 & \\
\hline & & & & & 13:57 & 21.69 & 572 & 7.07 & 7.81 & 135.1 & 64.7 & \\
\hline
\end{tabular}




\begin{tabular}{|c|c|c|c|c|c|c|c|c|c|c|c|c|}
\hline & & & & & & & & & & & \\
\hline 61 & US 150 & 59 & Lost R. & $8 / 11 / 03$ & $13: 45$ & 20.68 & 561 & 9.07 & 7.89 & 122.9 & 16.4 & \\
\hline & & & & & $13: 47$ & 20.68 & 564 & 8.25 & 7.84 & 121.1 & 13.3 & \\
\hline & & & & & & & & & & & & \\
\hline 63 & US 150 & 59 & Lost R. & $8 / 11 / 03$ & $14: 09$ & 18.70 & 583 & 10.58 & 7.94 & 162.2 & 15.0 & \\
\hline & & & & & $14: 11$ & 18.69 & 583 & 10.00 & 7.91 & 161.3 & 14.9 & \\
\hline 99 & US 150 & 59 & Lost R. & steep embankment, dangerous curve (nowhere to park) & & \\
\hline & & & & & & & & & & & & \\
\hline & & & & & & & & & & & & \\
\hline Fort Wayne District & & & & & & & & & & \\
\hline & High- & Co. & Water & & & Temp & Cond. & DO & pH & ORP & Turb. & Chlor. \\
ID \# & way & No. & Body & Date & Time & $(\mathrm{C})$ & $(\mu S / \mathrm{cm})$ & $(\mathrm{mg} / \mathrm{L})$ & $(\%)$ & $(\mathrm{mV})$ & $(\mathrm{NTU})$ & $(\mathrm{mg} / \mathrm{L})$ \\
\hline 36 & I-69 & 2 & Cedar & $7 / 29 / 03$ & $14: 15$ & 20.72 & 534 & 10.32 & 7.80 & 129.7 & 62.6 & \\
\hline & & & & & $14: 17$ & 20.71 & 534 & 10.08 & 7.80 & 128.3 & 64.4 & \\
\hline & & & & & & & & & & & & \\
\hline 37 & SR 1 & 2 & Cedar & $7 / 29 / 03$ & $14: 40$ & 21.32 & 511 & 10.76 & 7.87 & 133.3 & 76.4 & \\
\hline & & & & & $14: 42$ & 21.32 & 512 & 10.09 & 7.86 & 133.3 & 80.0 & \\
\hline & & & & & & & & & & & & \\
\hline 34 & SR 327 & 2 & Cedar & $7 / 29 / 03$ & $13: 55$ & 20.43 & 486 & 9.38 & 7.52 & 106.7 & 79.6 & \\
\hline & & & & & $13: 57$ & 20.44 & 486 & 9.13 & 7.52 & 108.4 & 80.0 & \\
\hline & & & & & & & & & & & & \\
\hline 35 & SR 327 & 2 & Cedar & $7 / 29 / 03$ & $13: 50$ & 19.77 & 477 & 9.98 & 7.54 & 124.5 & 43.2 & \\
\hline & & & & & $13: 52$ & 19.77 & 477 & 9.41 & 7.52 & 126.1 & 43.7 & \\
\hline & & & & & & & & & & & & \\
\hline 16 & SR 19 & 43 & Tippecanoe & $7 / 29 / 03$ & $11: 02$ & 21.39 & 541 & 8.04 & 7.88 & 111.8 & 14.2 & \\
\hline & & & & & $11: 04$ & 21.39 & 541 & 7.94 & 7.88 & 111.5 & 13.9 & \\
\hline & & & & & & & & & & & & \\
\hline 59 & US 6 & 57 & Elkhart R. & $7 / 29 / 03$ & $12: 22$ & 22.49 & 543 & 6.38 & 7.51 & 159.9 & 18.7 & \\
\hline & & & & & $12: 24$ & 22.51 & 543 & 6.13 & 7.51 & 157.8 & 18.1 & \\
\hline
\end{tabular}




\section{$\underline{\text { APPENDIX C }}$}

\section{POLLUTION PREVENTION AT INDOT OPERATION AND MAINTENANCE FACILITIES and for ROAD SIDE MAINTENANCE/ GOOD HOUSEKEEPING}

- The intent of this control measure is to ensure that existing and future highway and facility operations and maintenance are performed in ways that will minimize contamination of storm water runoff.

1. Highway and Roadside Maintenance

INDOT uses a Field Operations Handbook to guide maintenance workers in their tasks of maintaining the pavement, shoulders, side slopes, ditches, and rest areas. Those operations from the Handbook that may impact storm water quality for Highway and Roadside Maintenance are presented below. The environmental notes may be added to identify the additional measures that field personnel will have to perform to assure that storm water quality is protected. See the Environmental Notes at the end of this Appendix.

Shallow Patching - Minor patching of small areas of bituminous roadway or paved shoulder surface with hot or cold bituminous mixtures and hand tools to correct potholes, edge failures, and other potential surface hazards. This activity also includes temporary patching of bituminous and concrete surfaces and the use of hot liquid bituminous material and aggregate for patching bituminous surfaces or crack and joint spalling of concrete surfaces. Environmental Notes 1, 2, \& 3

Deep Patching -Major patching of roadway surface and paved shoulders to correct extensive surface failure caused by base failure, blowup, or settlement. Includes, on all surface types, the full depth removal of surface and base material and replacement with compacted bituminous mixture. Includes time spent cutting in preparation for deep patching. Includes cutting in preparation for deep patching. Environmental Notes 1, 2, \& 3

Premix Level - Minor machine or hand leveling and wedging of small isolated areas of bituminous or concrete roadway and shoulder surfaces with hot or cold bituminous mixtures to correct depressions at bridge ends, surface failures and depressions caused by settlement at pipe replacements and deep patches. Environmental Notes 1, 2, \& 3

Full Width Shoulder Seal - Seal Coating of continuous full width sections of paved shoulder surface with hot bituminous material and seal/cover aggregate to correct extensive cracking, seal the surface and restore shoulder life. Includes routing of the joints and taping of pavement markings in preparation for sealing. Shoulders with rumble strips should not be sealed. Environmental Notes 1, 2, 3, \& 7 
Seal Coating-Chip - Seal Coating continuous full width section of roadway surface with hot bituminous material and coarse aggregate to correct extensive cracking, raveling, spalling, and shallow surface failures and to prevent deterioration of the surface. Includes routing of joints and taping of pavement markings in preparation for sealing. Environmental Notes $1,2,3, \& 7$

Sealing Longitudinal Cracks And Joints - Mechanical cleaning and sealing longitudinal cracks and joints with a liquid bituminous sealant to prevent the entry of moisture and debris which leads to surface and base failure. Includes the edge cracks between concrete surfaces and bituminous shoulder, the widening cracks and the centerline joint. Includes routing of joints and taping of pavement markings in preparation for sealing. Environmental Notes 1, 2, \&3

Sealing Cracks - Cleaning and sealing open cracks and joints in bituminous and concrete roadways and paved shoulder surfaces to prevent the entry of moisture and debris, which leads to surface, and base failure. This activity also includes sealing short sections or isolated areas of alligatored, raveled, or spalled bituminous surfaces to prevent entry of moisture and further deterioration of the surface. Also includes routing of joints and taping of pavement markings in preparation for sealing. Environmental Notes $1,2, \& 3$

Sealing Coating-Sand - Seal coating continuous full width sections of roadway surface with hot liquid bituminous material and fine aggregate (sand) to correct extensive cracking, raveling, and shallow surface failures and to prevent deterioration of the surface. Includes routing of joints and taping of pavement markings in preparation for sealing. Environmental Notes $1,2,3, \& 7$

Sealing Cracks with Crumb Rubber Material - Cleaning and sealing cracks and joints in bituminous and concrete roadways and paved shoulder surfaces to prevent the entry of moisture and debris, which leads to surface, and base failure. Includes routing of joints and taping of pavement markings in preparation for sealing. Environmental Notes 1, 2, \& 3

Spot Repair of Shoulders - Repairing small areas of shoulders by adding aggregate, reshaping and compacting to correct edge ruts, potholes, and corrugations and to replace lost material at washouts, around mailboxes, and public road approaches. Note: This activity is used for reporting work on aggregate shoulders and/or any aggregate areas adjacent to a paved shoulder. Repairs to paved shoulders should be reported to Activity 2010 (SHALLOW PATCHING) or Activity 2020 (DEEP PATCHING) as appropriate. Environmental Notes $1,2,3, \& 7$ 
Blading Shoulders - Blading and reshaping shoulders to eliminate edge ruts, ridges, corrugations and high shoulders. Environmental Notes 2, 3, $4, \& 7$

Clipping Shoulders - Major clipping of overgrown shoulders to remove excess material and to restore proper slope for adequate drainage. Includes clipping of overgrown shoulders adjacent to the driving surface and sod adjacent to paved or aggregate shoulder. Also includes related cleaning and reshaping of the adjacent roadside ditches as required. Environmental Notes $2,3,4, \& 7$

Recondition Shoulders - Reconditioning continuous shoulder sections by adding aggregate, reshaping and compacting to restore the shoulder grade and surface. Envirommental Notes $2,3,4, \& 7$

Joint And Bump Repair - Grinding or planing of bituminous surfaces to remove bumps, ripples and heaved joints. Includes sealing of areas at a later date. Environmental Notes $1,2,3, \& 7$

Other Roadway and Shoulder Maintenance - Other routine work activities performed on the roadway or shoulder surface that are not specifically identified as separate work activities. This activity does not include work that is directly related to another activity such as preparation and clean up. Environmental Notes 1, 2, 3, 4, \& 7

Machine Mowing - Machine mowing of roadside vegetation within the designated mowing limits of the right-of-way using tractor mowers and hand trimming as required, to maintain an attractive roadside and to control erosion and drainage. This activity does not include the hand mowing and trimming at rest areas, roadside parks and picnic areas. Environmental Notes $2 \& 10$

Brush Cutting - Cutting, trimming and removing brush, small trees, tree branches and limbs within the right-of-way using power or hand tools to restore sight distance, eliminate traffic hazards and remove encroaching vegetation. Environmental Notes 2, 8, \& 10

Herbicide Treatment - Application of chemicals to roadside vegetation and soil along shoulders, guardrail sections, around sign posts, delineators, mail boxes, bridge ends and other areas to eliminate or control undesirable vegetation. Environmental Note 2

Seed and/or Fertilizing - Seeding, reseeding, and fertilizing of shoulders, front and back slopes, medians and other designated areas to restore vegetation for erosion control and beautification. Environmental Notes 2 \& 4 
Topping Trimming or Removal of Trees - Topping, trimming or removal of large trees within the right-of-way requiring the use of equipment such as a bucket truck and a boom truck. Includes stump removal when performed as a part of the tree operation. Environmental Notes $2,8, \& 10$

Stump Removal - Removal of stumps within the right-of-way to eliminate traffic hazards or improve efficiency of other maintenance activities. (Stump cutting performed in conjunction with tree removal should be reported to Activity 2250) Environmental Notes 2, 3, 4, \& 8

Spot Mowing and Hand Trimming - Spot or hand mowing to control Johnson grass, Canadian thistle and other noxious weeds, and hand trimming or mowing needed in addition to that performed during Machine Mowing (Activity 2210). This activity does not include hand mowing or trimming at rest areas, roadside parks, districts, Subdistrict or unit location. Environmental Notes $2 \& 10$

Right-Of-Way Fence - Repair damaged, state-owned, right-of-way fencing to maintain delineation of the right-of-way. Includes rebuilding existing fence using in place material and/or replacing short sections of damaged fencing with new materials. This activity does not include repair of fence at district, subdistrict or unit site. Environmental Notes $2,4, \& 10$

Other Roadside Maintenance - Other routine maintenance activities that are not specifically identified as separate activities. Note: Work performed in preparation of or as follow up to a specific activity is to be recorded to that activity. Environmental Notes 2, 3, 4, \& 8

Clean and Reshape Ditches - Machine cleaning of roadside ditches with excavating equipment to restore original grade and maintain adequate drainage. Includes the loading, hauling, and disposal of excess material, reshaping front and back slopes, and shoulder restoration as related to ditching. May also include pipe replacement in the ditch line and under driveways. Environmental Notes 2, 3, 4, 5, 6, 8, \& 10

Inspect Minor Drainage Structures - Inspecting and minor cleaning of all minor drainage structures including box culverts, pipe culverts, catch basins, inlets and paved side ditches with emphasis on small cross culverts. Inspect to determine both structural and drainage adequacy. Defects should be reported for future scheduling. Environmental Notes 2, $3,4,5,6, \& 10$

Pipe Replacement - Cross Pipe culvert replacement and/or pipe liner installation required as a result of damage or deterioration in order to maintain adequate drainage. Includes state-owned pipes at intersections of county roads, but does not include pipes installed in the ditch line or pipes installed under driveways. Environmental Notes $2,3,4,5,6, \& 10$ 
Motor Patrol Ditching - Machine cleaning of roadside ditches with motor patrol to restore original grade and maintain adequate drainage. Includes the loading, hauling, and disposal of excess material, reshaping front and back slopes, pipe culvert replacement and shoulder restoration as related to ditching. Environmental Notes $2,3,4,5,6,8,9$ \& 10

Cleaning Minor Drainage Structures - Manual or machine cleaning and removal of debris from box culverts, pipe culverts, catch basins, inlets and paved ditches to maintain adequate drainage. Environmental Notes 2, 3, $5,9, \& 10$

Clean Underdrains - Clean inside and outside of underdrains pipes to restore adequate drainage flow. Mark locations of outlets. Environmental Notes $2,3,9, \& 10$

Other Drainage Maintenance -Other routine drainage maintenance activities that are not specifically identified as separate activities. Environmental Notes $2,3,4,5,6,8,9$, \& 10

Hand Cleaning Bridges - Cleaning of bridge deck surfaces, expansion joints, drains holes, bridge seats and sidewalks by hand shoveling, or sweeping and air blasting to remove accumulation of sand, chemicals and debris. Environmental Notes $2,3,9, \& 10$

Bridge Repair - Minor repairs to bridge structures including repair, replacement or painting of handrails, curbs or sidewalks repair, minor joint and deck repair, timber deck repair, support repair, deck sealing and other minor repairs. Includes emergency deck or support repair and minor maintenance of lift bridges. Also includes preparation work and taping of pavement markings in preparation for bridge repair. Environmental Notes $1,2,3,5,6,9, \& 10$

Flushing Bridge - Cleaning of bridge seats, drain holes, expansion joints, gutter lines and truss members by flushing to remove accumulation of sand, chemicals, and debris. Environmental Notes 2, 3, \& 10

Patching Bridge Decks - patching of bridges using a Portland Cement, concrete or approved epoxy adhesive. Includes marking, sawing and breaking out old concrete with jackhammers. Environmental Notes 1, 2, $3,9, \& 10$

Other Bridge Maintenance - Other routine bridge maintenance activities that are not specifically identified as separate activities. Environmental Notes $1,2,3,5,6,9, \& 10$

Emergency Maintenance - Emergency or extraordinary temporary repairs, traffic control and clean up of roadway, roadside, and structures on the State Highway System in response to emergency conditions. Overtime callout for routine maintenance activities such as patching, sign 
repair, or drainage maintenance should be charged to the repair activity if permanent repairs are made. Environmental Notes $1,2,3,4,5,6,7,8,9$, $\& 10$

Snow and Ice Removal - This activity includes all operations during and after a storm required to remove snow and ice from the roadway. Includes loading operations required to support snow and ice removal operations, removal of snow from ditches, removal of ice caused by flooding and opening of frozen drains. Environmental Notes 2

Winter Patrol - Patrol of roads during the winter season (November 1April 1) to determine the development of hazardous conditions requiring attention by maintenance forces. Environmental Notes $2,3, \& 10$

Other Winter Maintenance - Other routine winter maintenance activities that are not specifically identified as separate activities. Envirommental Notes $2,3, \& 10$

Rest Area and Lift Bridge Attendant - The care and cleaning of rest areas and enforcement of INDOT policies for rest areas and enforcement of INDOT policies for rest area usage and operation of lift bridges on the State Highway system by full time attendants. Environmental Notes 1, 2, $3,4,5,6,7,8,9, \& 10$

Roadside Park, Rest Area and Weigh Station Maintenance - Maintenance of building, grounds and parking lots of state maintained rest areas, roadside parks and weigh stations. This activity is performed on interstate only. All other such work is reported to Facilities Activities (2830+Subactivity) Environmental Notes $1,2,3,4,5,6,7,8,9, \& 10$

Work for Department of Natural Resources - All maintenance activities performed on the designated roadways and parking areas of the Indiana Department of Natural Resources. Environmental Notes 1, 2, 3, 4, 5, 6, 7, $8,9, \& 10$

Work for State Institutions - All maintenance activities performed on the designated roadways of the State of Indiana institutions. Environmental Notes $1,2,3,4,5,6,7,8,9$, \& 10

Full Width Litter Pickup - Full width cleaning of continuous sections of the right-of-way area including pickup, loading, hauling and disposing of accumulated litter to remove unsightly or hazardous objects and obstructions to drainage. . Environmental Notes 2, 3, 6, 8, 9, \& 10

Currently INDOT has a program called Trash Bash. This program involves picking up trash along the right-of-way each Spring before mowing begins. Division of Corrections labor is also utilized for the trash pickup. Environmental Notes $2,3,6,8,9, \& 10$ 
Spot Litter Pickup - Cleaning isolated sections of the right-of-way including pickup, loading and disposing of litter and debris to remove unsightly or dangerous objects. Environmental Notes $2,3,6,8,9, \& 10$

Roadway Cleaning - Mechanical or manual sweeping of roadway, including intersections, curbs and gutters, to remove excess loose sand, chemicals, and debris. Manual cleaning of bridges should be reported as Activity 2410, Hand Cleaning Bridge Decks. Environmental Notes 2, 3, $6,8,9, \& 10$

Material Handling and Storage - Handling and storage materials for routine maintenance activities excluding snow and ice control materials. Includes the loading, hauling, unloading, mixing, stockpiling, and storage of material. Environmental Notes $2,6, \& 10$

Maintenance Improvements - Non-routine work not requiring special funding performed by maintenance forces on the State Highway System. For planning purposes, this activity includes improvements on all the various elements of the system-surface, shoulders, roadside, and Department buildings and grounds. Environmental Notes 1, 2, 3, 4, 5, 6, $7,8,9, \& 10$

\section{Facilities Operation and Maintenance}

Those operations from the Field Operations Handbook that are pertinent to storm water quality for Operations and Maintenance Facilities are:

Stockpiling Winter Material - The stockpiling, mixing and processing of abrasives and chemicals performed before and during the winter season.

Environmental Notes 2

Equipment Servicing - The routine service and maintenance of the Department's equipment fleet. Environmental Notes $2 \& 10$

Buildings \& Grounds Maintenance - The general maintenance and caretaking of the buildings and grounds at District, Subdistrict, and other maintenance unit locations. Environmental Notes $1,2,3,4,5,6,7,8,9$, $\& 10$

Scraping and Painting of Equipment - Manual scraping of loose paint to remove from equipment. Rust should also be removed. Painting equipment to improve appearance and to increase life span of equipment. Note: When Unit Foreman or crew leaders are working as a part of a crew (not supervising other crews) their time is to be reported to the activity they are performing. Environmental Notes $2,8,9$, \& 10 


\section{Environmental Notes for Operation and Maintenance Activities:}

1. Application of liquid asphalts shall be as required and shall not result in excess material leaving roadway surface and entering ditches or waterways. Liquid asphalt shall not be applied if rain is forecast within the time required for the asphalt to cure to its solid state.

2. Cleanup of tools and equipment shall be accomplished in a controlled manner and special emphasis shall be placed on not allowing any materials from this cleaning to enter the environment.

3. Excavated materials such as rock, old concrete, old asphalt, and soil are considered clean fill and may be re-used at the jobsite if environmental concerns are satisfied. If necessary, excavated materials may have to be hauled back to the INDOT facility for later use or disposal (soil for shoulder reconstruction, old concrete as riprap).

4. Excavated areas, bladed shoulder edges, exposed bare soil, and shallow-sloped erosion areas shall be mulch seeded or sodded, as directed by the supervisor, in accordance with INDOT Standard Specification Section 621. Seeded areas shall be checked weekly to assess their condition.

5. In highly erodeable ditch areas riprap check dams, or other erosion and sediment control measures shall be installed, as directed by the supervisor, in accordance with INDOT Standard Specification Section 205, and INDOT Standard Drawings 205 for installation of Erosion Control Measures. On highly erodeable side slopes, riprap shall be installed, as directed by the supervisor, in accordance with INDOT Standard Specification Section 616.

6. Scrap metal pipes or portions of pipes shall be transported back to the INDOT facility.

7. Application of aggregates and sand materials shall be done in such a manner that excessive amounts of material do not escape the roadway surface.

8. Process all cut trees or brush through the chipper/spreader. If it is not possible to process trees or brush through the chipper/spreader, transport material back to INDOT facility for disposal. It is preferred to utilize the chips in compost or as ground cover at state properties. Incineration may be considered if allowed by local ordinance.

9. If material to be removed exhibits odor, it will be tested before removal to insure proper disposal. Contact the District Environmental Coordinator. After suspect material is removed, it is to be segregated, so as not to contaminate clean material.

10. The types of material encountered along the Right-of-way consists of soil, tires, and general debris. INDOT encourages field personnel to segregated and recycled the larger metal material. Tires are to be transported to a district tire recycling location and the general debris to be properly disposed of. 
APPENDIX B 
$n$
4
0
0
0
0
0

के

号

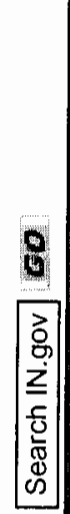

ำ 든

응

तेष

离宫

(1)

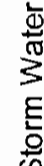

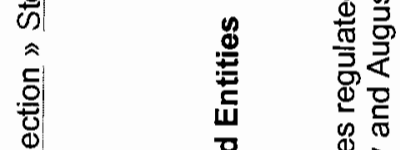

3 i

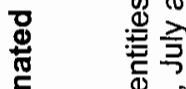

훙

웜

$\frac{2}{1}$

두요

宓

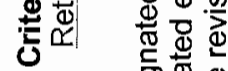

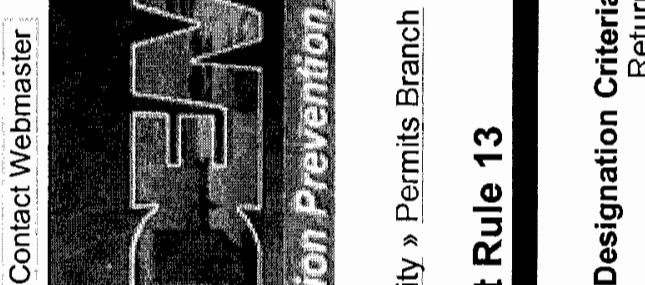

동

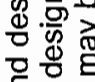

क्ष

要

긍 $\overline{\bar{\sigma}}$

응ำ

흥

\&

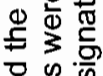

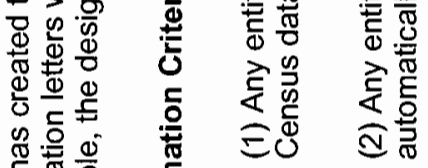

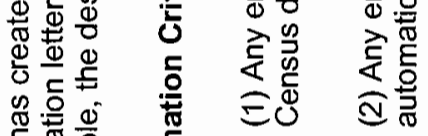

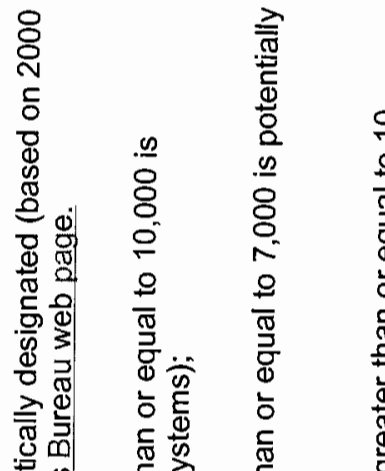

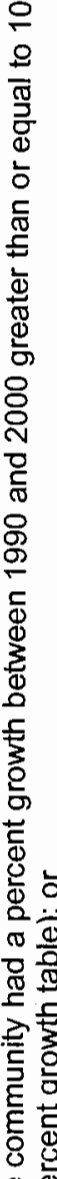

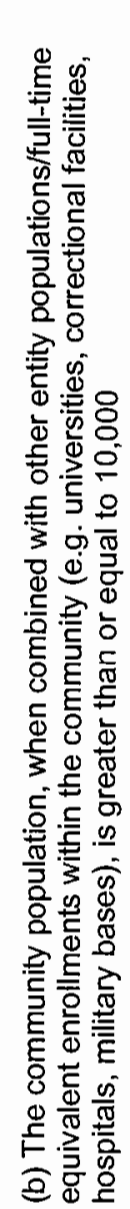

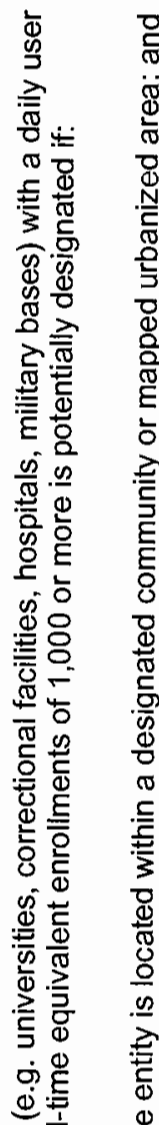

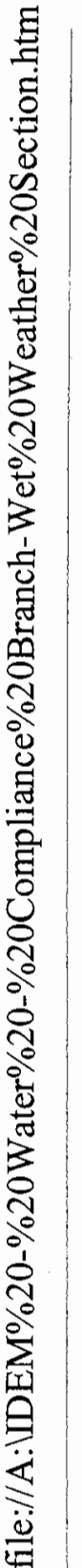

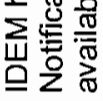

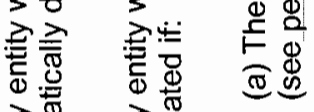

䆜突 这交衣

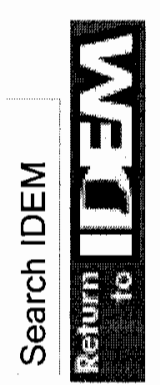




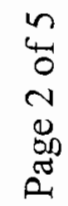
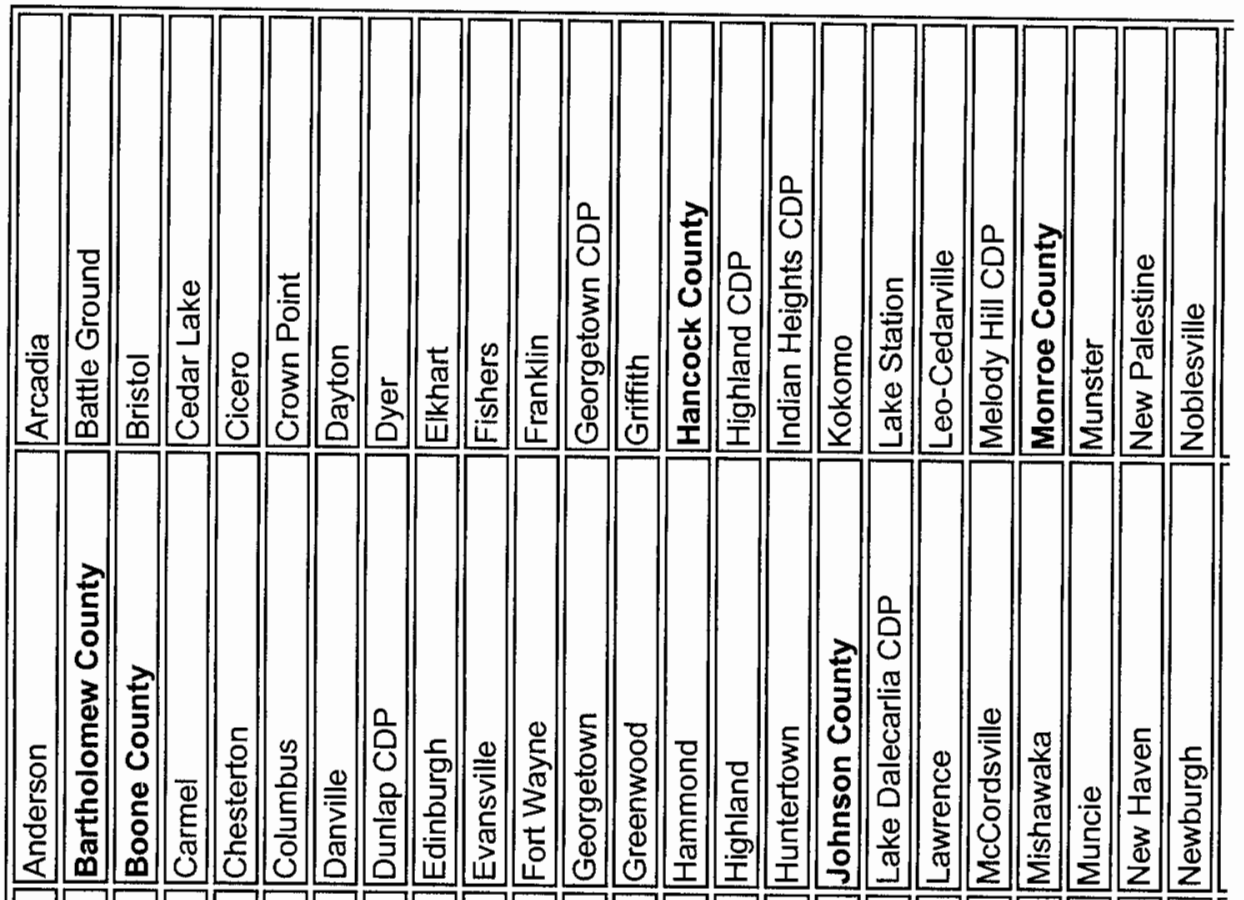

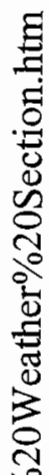

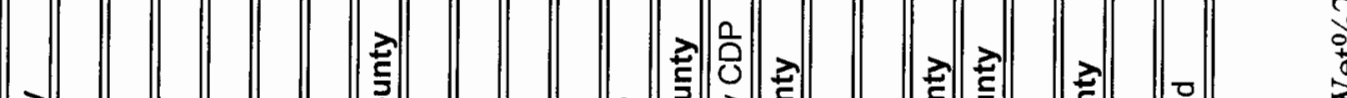

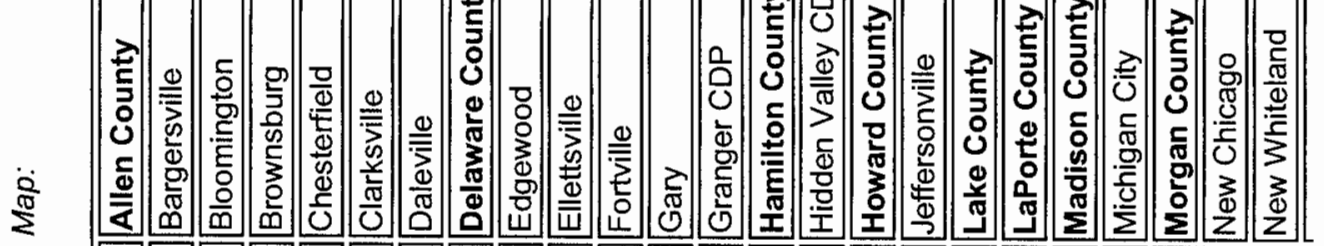

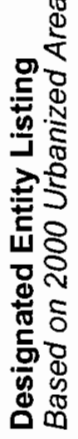
$\mid$

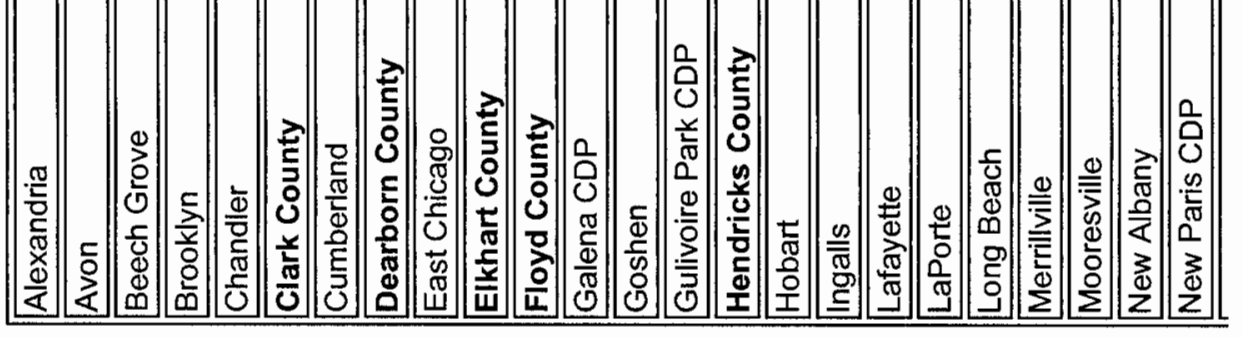


$n$
4
0
0
0
0
0
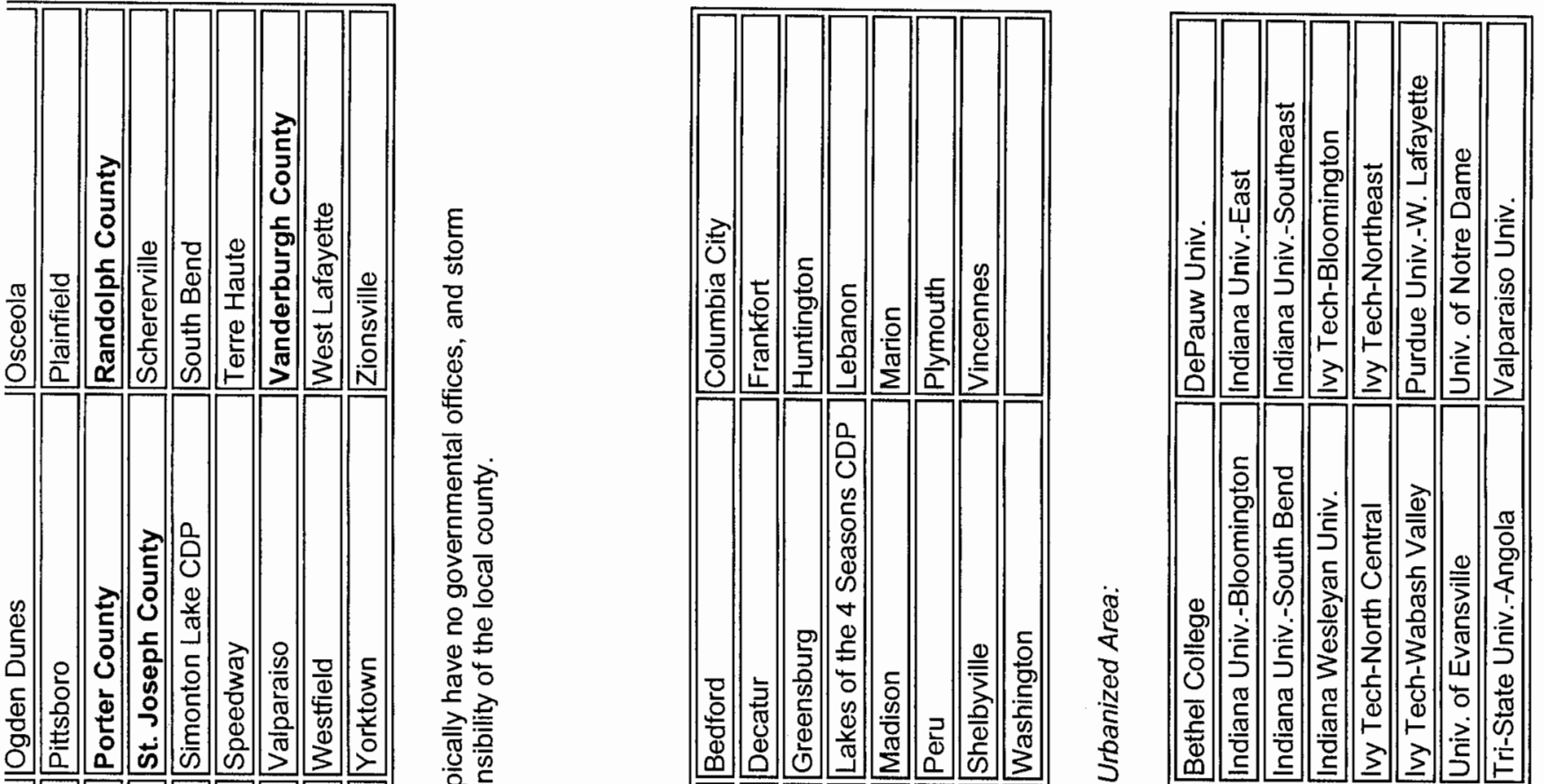

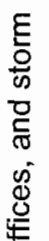

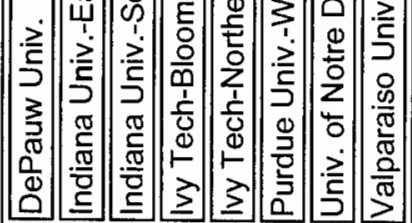

焉

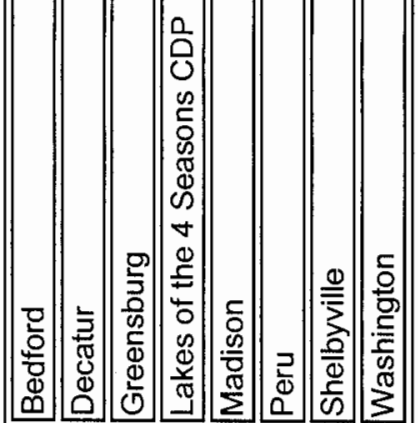

홍ㅁㅇㅇ

잉응

눈

空

증

을 둥

ฐ

宁

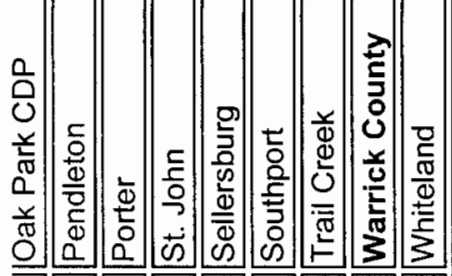

焉

ष्ठ

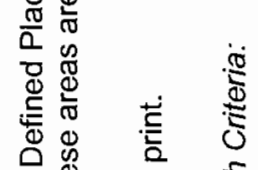

की

흥 홍

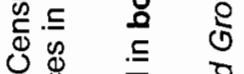

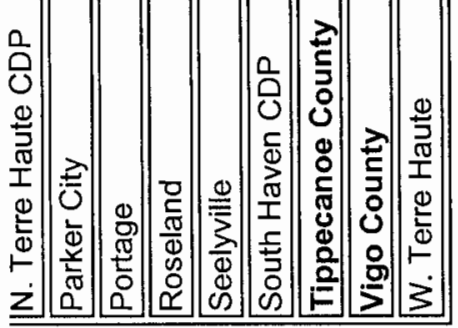

要

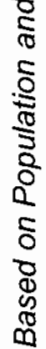
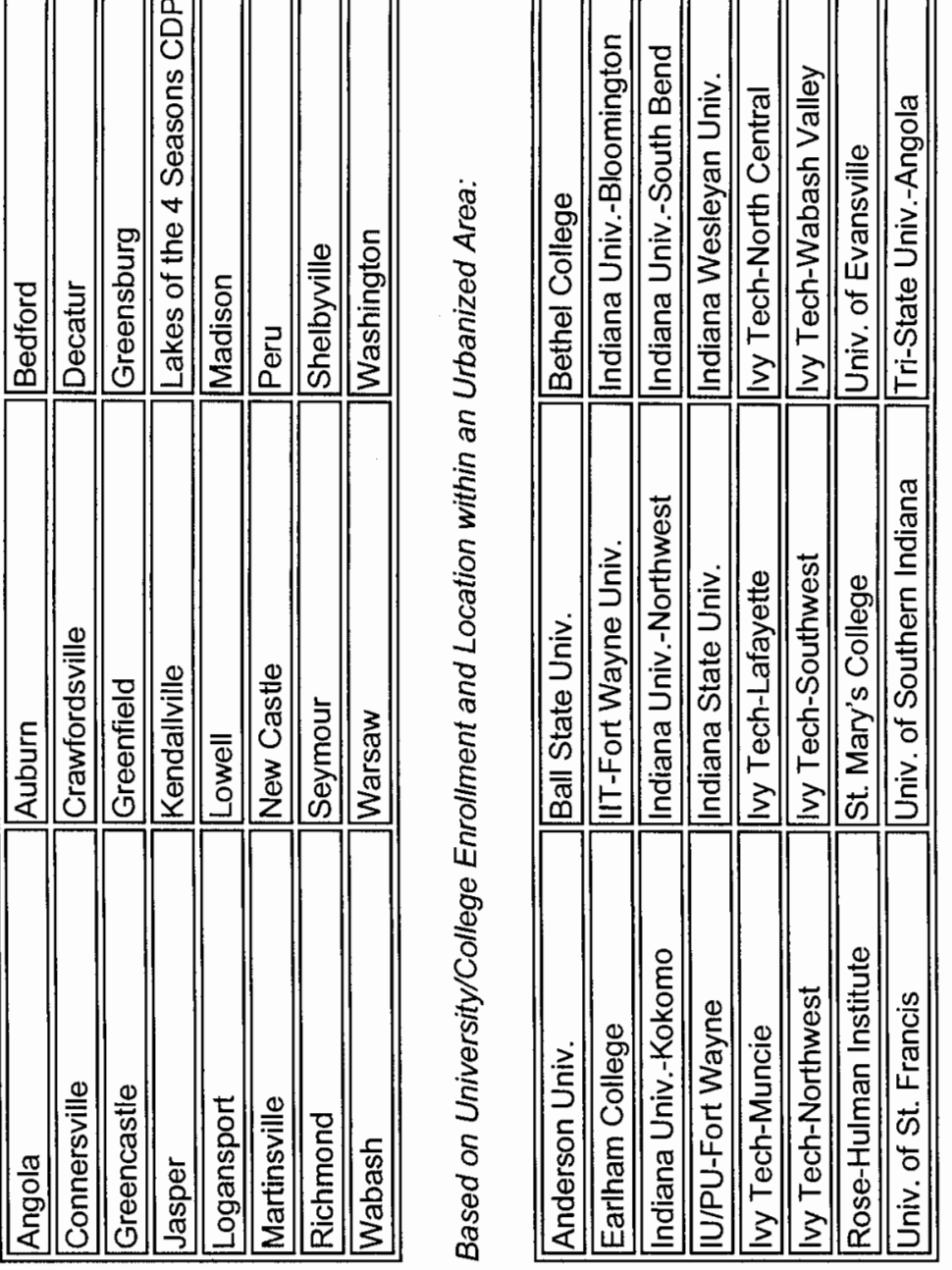

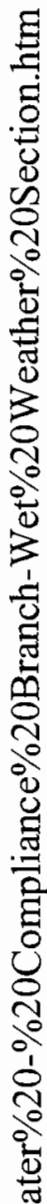

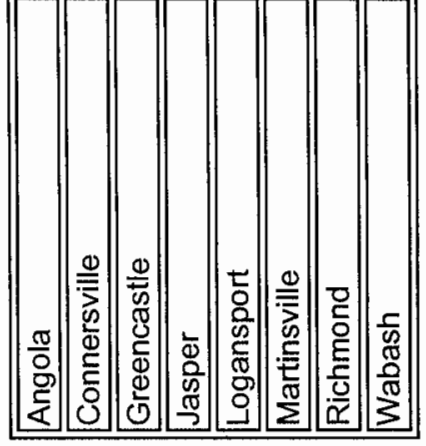




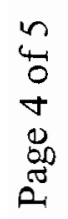
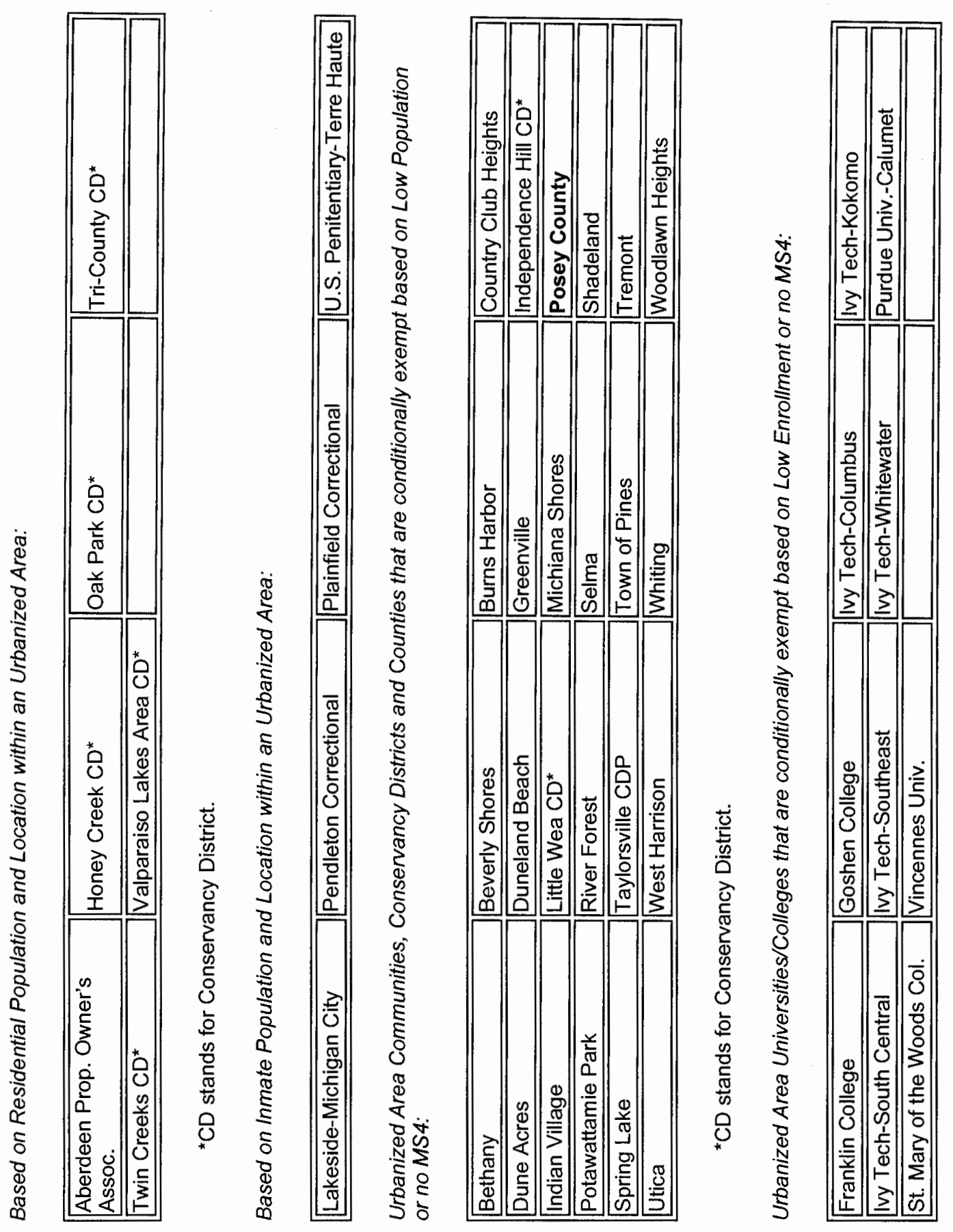

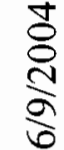
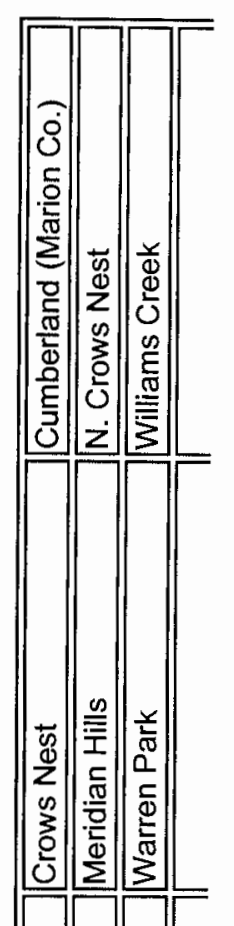

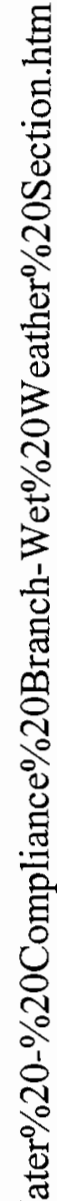

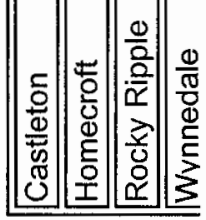

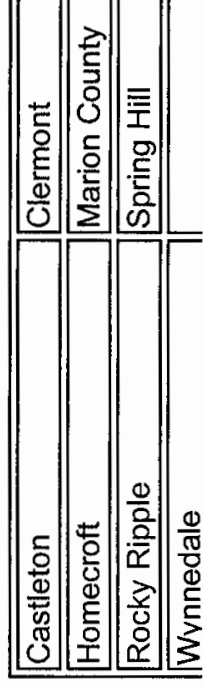


$n$
4
0
$n$
0
00
0
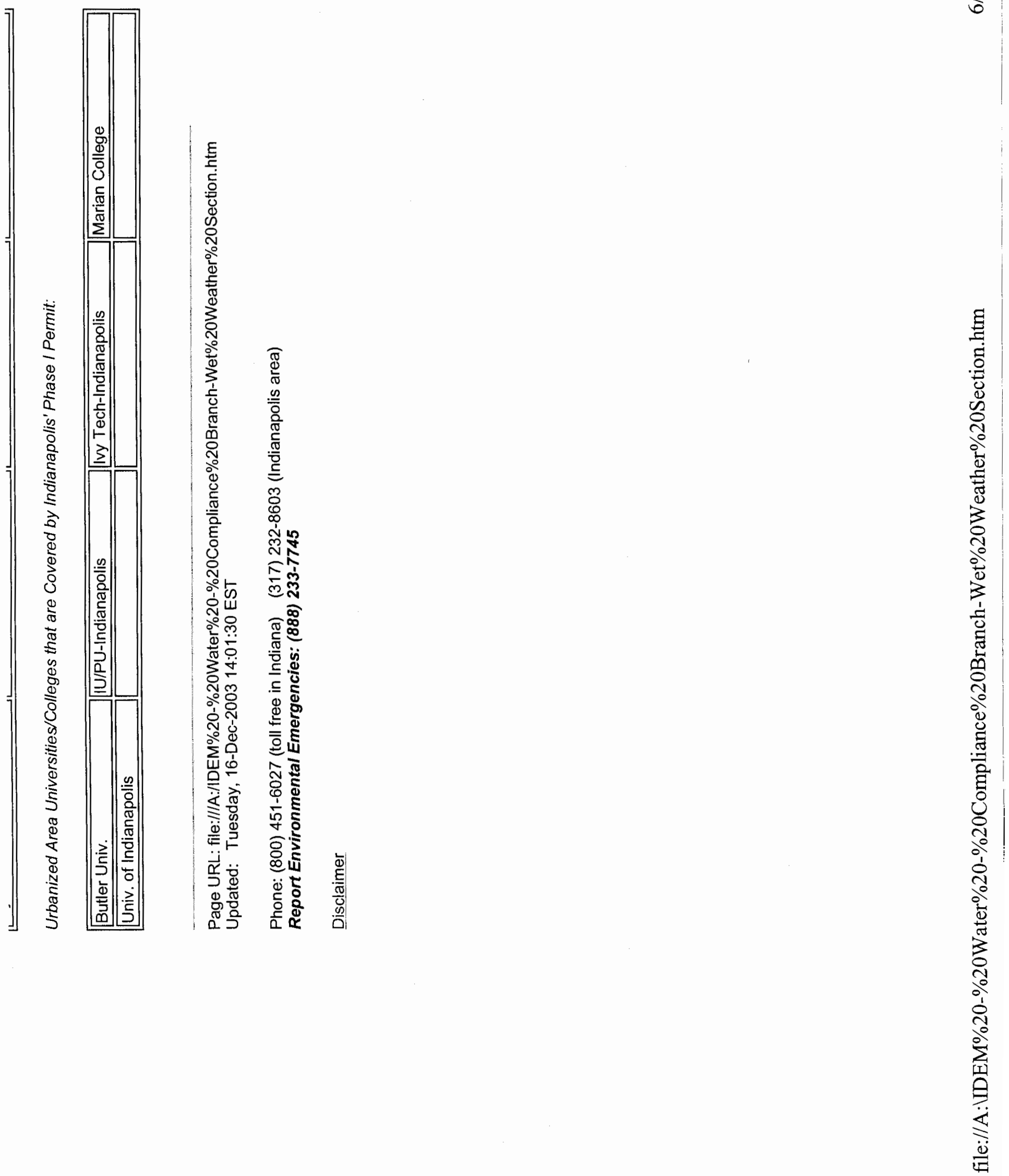


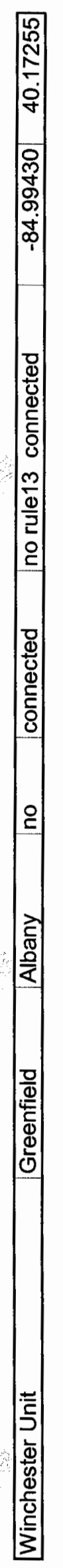


APPENDIX C 
Analysis of 2003 GPS locations for District, sub, unit and salt facilities.

New file has 146 individual locations.

16 are different than the 2000 version file we have been using.

Differences:

1. Layafette Unit is incorrect in the new file, the location given is the research parking lot. (This was in error in the 2000 version as well but we fixed it.)

2. The 7 Toll road locations are slightly different (between 50 to 240 feet.) Possibly represents staff using a different (better) GPS unit. I checked the 7 Toll Road facilities.

Our original file and the new file are consistent in terms of still being located on the same site (the difference is smaller than the actual facilities.) We should note that both the new and old location of the LaPorte Toll Road Maint. Facility is 450 feet north east of the true location, according to the 1999 aerial photos. Both old and new database have points located in an empty field north of the toll road, rather than south like the facility in the photo.

3. Rensselaer and Dale are new locations.

4. Ashboro Unit is 250 feet SE of old point location. Same facility on photo. Old location was equipment barn, new location is salt piles.

5. Wanatah Unit is 266 feet NE of old point location. Same facility on photo. Old location was driveway, new location is salt loaders.

6. Medaryville Unit is 2500 feet north of old point. New point is correct, old point was in an empty field.

7. Sellersburg Unit is 690 feet NW of old point. New point is driveway and old point is equipment barn.

8. Mount Vernon Satellite (Vincennes District) is new to us.

9. Vincennes Sub is new point 420 feet southeast of old "Vincennes Unit and sub"point. The old database had 1 point for Vincennes District, unit and sub; this is now split into a district point and a sub point. However both the new points are still 325 feet north of the true location. Both databases have points for Vincennes district office and sub that are located in a field 325 feet north of the actual facilities.

10. "Crawfordsville District" and "Crawfordsville Sub" are now two points with the same location where we had two points before, labeled as "Crawfordsville District" and "Crawfordsville Sub and Unit"

In conclusion, Rensselaer and Dale and Mount Vernon Satellite are new points, and Medaryville is a better location; the rest are not significant changes to the existing analysis. 5 facilities which were in the old analysis are noted as closed (but still used for storage) Valparaiso Unit, Old Madison sub, Hanna Unit, Orland Unit, Warren Unit.

Aug 09, 2003 Larry Theller 


\begin{tabular}{|c|c|c|c|c|c|c|c|}
\hline \multicolumn{8}{|c|}{ spreadsheet created $05 / 24 / 04$ to display the current version of the latitude-longitude of the Indot Facility map layer. } \\
\hline FACILITIES & DISTRICT_NAME & SUBDISTRICT & RULI & CONNECTION & COMBINED & LONGITUDE & LATITUDE \\
\hline Aberdeen Unit & Seymour & Aurora & no & not connected & no rule13 not connected & -84.98933 & 38.90453 \\
\hline Albany Sub & Greenfield & Albany & no & connected & no rule13 connected & -85.21152 & 40.29730 \\
\hline Alexandria Unit & Greenfield & Albany & yes & connected & yes rule13 connected & -85.66927 & 40.27845 \\
\hline Amity Unit & Seymour & Columbus & no & not connected & no rule13 not connected & -85.99427 & 39.41203 \\
\hline Anderson Unit & Greenfield & Greenfield & yes & connected & yes rule13 connected & -85.66295 & 40.04855 \\
\hline Angola Sub & Fort Wayne & Angola & yes & connected & yes rule 13 connected & -85.02712 & 41.63255 \\
\hline Ashboro Unit & Crawfordsville & Terre Haute & no & not connected & no rule13 not connected & -87.11183 & 39.38923 \\
\hline Aurora Sub & Seymour & Aurora & no & connected & no rule13 connected & -84.96910 & 39.03258 \\
\hline Bainbridge Unit & Crawfordsville & Cloverdale & no & not connected & no rule 13 not connected & -86.87915 & 39.76162 \\
\hline Beanblossom Unit & Seymour & Bloomington & no & not connected & no rule13 not connected & -86.25563 & 39.29290 \\
\hline Bedford Unit & Vincennes & Paoli & yes & connected & yes rule13 connected & -86.52283 & 38.86370 \\
\hline Birdseye Unit & Vincennes & Tell City & no & not connected & no rule 13 not connected & -86.70173 & 38.23072 \\
\hline Bloomfield Unit & Vincennes & Linton & no & connected & no rule 13 connected & -86.93553 & 39.01775 \\
\hline Bloomingdale Unit & Crawfordsville & Veedersburg & no & not connected & no rule 13 not connected & -87.23715 & 39.81805 \\
\hline Bloomington Sub & Seymour & Bloomington & yes & connected & yes rule 13 connected & -86.55317 & 39.19512 \\
\hline Bluffton Sub & Fort Wayne & Bluffton & no & not connected & no rule13 not connected & -85.27850 & 40.74272 \\
\hline Brimfield Unit & Fort Wayne & Goshen & no & not connected & no rule13 not connected & -85.41545 & 41.45373 \\
\hline Brookville Unit & Seymour & Aurora & no & not connected & no rule 13 not connected & -85.00860 & 39.42372 \\
\hline Brownstown Unit & Seymour & Columbus & no & not connected & no rule13 not connected & -86.11375 & 38.88128 \\
\hline Cambridge City Unit & Greenfield & Centerville & no & not connected & no rule13 not connected & -85.14323 & 39.85115 \\
\hline Carbondale Unit & Crawfordsville & Fowler & no & not connected & no rule13 not connected & -87.35097 & 40.34610 \\
\hline Centerville Sub & Greenfield & Centerville & no & not connected & no rule 13 not connected & -84.97508 & 39.81868 \\
\hline Chandler Unit & Vincennes & Evansville & yes & connected & yes rule13 connected & -87.37530 & 38.04357 \\
\hline Chesterton Unit & LaPorte & LaPorte & yes & not connected & yes rule13 not connected & -87.04123 & 41.63593 \\
\hline Chrisney Unit & Vincennes & Dale & no & connected & no rule 13 connected & -87.03693 & 38.02133 \\
\hline Cloverdale Sub & Crawfordsville & Cloverdale & no & connected & no rule13 connected & -86.80005 & 39.53515 \\
\hline Columbus Sub & Seymour & Columbus & yes & connected & yes rule13 connected & -85.96153 & 39.19727 \\
\hline Corydon Unit & Seymour & Falls City & no & connected & no rule13 connected & -86.13527 & 38.24897 \\
\hline Crawfordsville District & Crawfordsville & Crawfordsville & yes & connected & yes rule13 connected & -86.90800 & 40.08233 \\
\hline Crawtordsville Sub & Crawtordsville & Crawfordsville & yes & connected & yes rule13 connected & -86.90800 & 40.08233 \\
\hline Crown Point Unit & LaPorte & Gary & yes & not connected & yes rule13 not connected & -87.31185 & 41.38233 \\
\hline Dale Old Unit (and test lab) & Vincennes & Dale & no & connected & no rule13 connected & -86.98688 & 38.16722 \\
\hline Dale Unit (new) & Vincennes & Dale & no & not connected & no rule13 not connected & -86.97665 & 38.19620 \\
\hline Derby Unit & Vincennes & Tell City & no & connected & no rule13 connected & -86.62582 & 38.06048 \\
\hline Elkhart Maintenance facility & Toll Road District & Toll Road & yes & not connected & yes rule13 not connected & -86.06183 & 41.73171 \\
\hline Elkhart Sub (new) & Fort Wayne & Goshen & yes & connected & yes rule13 connected & -85.96523 & 41.63922 \\
\hline Evansville Sub & Vincennes & Evansville & no & connected & no rule13 connected & -87.54938 & 38.12972 \\
\hline
\end{tabular}




\begin{tabular}{|c|c|c|c|c|c|c|c|}
\hline Evansville Unit & Vincennes & Evansville & yes & connected & yes rule13 connected & -87.61500 & 37.97397 \\
\hline Falls City Sub & Seymour & Falls City & yes & connected & yes rule13 connected & -85.75160 & 38.34720 \\
\hline Flora Unit & LaPorte & Monticello & no & not connected & no rule13 not connected & -86.52707 & 40.53367 \\
\hline Fort Harrison Unit & Crawiordsville & Terre Haute & yes & not connected & yes rule13 not connected & -87.37393 & 39.50728 \\
\hline Fort Wayne District & Fort Wayne & Fort Wayne & yes & connected & yes rule 13 connected & -85.17795 & 41.12750 \\
\hline Fort Wayne Sub & Fort Wayne & Fort Wayne & yes & connected & yes rule 13 connected & -85.17752 & 41.12627 \\
\hline Fortville Unit & Greenfield & Tipton & no & not connected & no rule13 not connected & -85.84178 & 39.99630 \\
\hline Fowler Sub & Crawfordsville & Fowler & no & not connected & no rule 13 not connected & -87.31620 & 40.61278 \\
\hline Frankfort Sub & Crawfordsville & Frankfort & yes & connected & yes rule 13 connected & -86.53312 & 40.27805 \\
\hline Frankfort Unit & Crawfordsville & Frankfort & yes & connected & yes rule13 connected & -86.53375 & 40.27815 \\
\hline Gary Sub & LaPorte & Gary & yes & not connected & yes rule13 not connected & -87.42950 & 41.58868 \\
\hline Gas City Unit & Fort Wayne & Wabash & no & connected & no rule13 connected & -85.56815 & 40.48197 \\
\hline Goshen Sub & Fort Wayne & Goshen & yes & connected & yes rule13 connected & -85.82408 & 41.57177 \\
\hline Grantsburg Unit & Vincennes & Tell City & no & not connected & no rule 13 not connected & -86.47035 & 38.29677 \\
\hline Greenfield District & Greenfield & Greenfield & yes & connected & yes rule 13 connected & -85.77993 & 39.78335 \\
\hline Greenfield Sub & Greenfield & Greenfield & yes & connected & yes rule13 connected & -85.78272 & 39.78212 \\
\hline Greensburg Unit & Seymour & Columbus & yes & not connected & yes rule13 not connected & -85.51945 & 39.36447 \\
\hline Hanna Unit (closed) & LaPorte & LaPorte & no & not connected & no rule13 not connected & -86.73800 & 41.42577 \\
\hline Indianapolis Sub & Greenfield & Indianapolis & yes & not connected & yes rule13 not connected & -86.04525 & 39.72615 \\
\hline Jasper Unit & Vincennes & Dale & yes & connected & yes rule13 connected & -86.89835 & 38.36563 \\
\hline Kentland Unit & LaPorte & Rensselaer & no & not connected & no rule13 not connected & -87.43922 & 40.81237 \\
\hline Kokomo Unit & Greenfield & Tipton & yes & not connected & yes rule 13 not connected & -86.05473 & 40.47873 \\
\hline Lafayette Unit & Crawtordsville & Fowler & yes & not connected & yes rule13 not connected & -86.87205 & 40.48867 \\
\hline LaGrange Maintenance facility & Toll Road District & Angola & no & not connected & no rule13 not connected & -85.54600 & 41.74635 \\
\hline Lake Maintenance facility & Toll Road District & Gary & yes & connected & yes rule 13 connected & -87.50660 & 41.63867 \\
\hline LaPorte District & LaPorte & LaPorte & yes & connected & yes rule13 connected & -86.69163 & 41.58508 \\
\hline LaPorte Maintenance facility & Toll Road District & LaPorte & no & not connected & no rule 13 not connected & -86.68276 & 41.67366 \\
\hline LaPorte Sub & LaPorte & LaPorte & yes & connected & yes rule13 connected & -86.69452 & 41.58460 \\
\hline Laud Unit & Fort Wayne & Warsaw & no & not connected & no rule13 not connected & -85.46875 & 41.08290 \\
\hline Lebanon Unit & Crawfordsville & Frankfort & yes & not connected & yes rule 13 not connected & -86.50633 & 40.07948 \\
\hline Liberty Unit & Greenfield & Centerville & no & not connected & no rule13 not connected & -85.01287 & 39.63208 \\
\hline Linton Sub & Vincennes & Linton & no & connected & no rule13 connected & -87.16908 & 39.03038 \\
\hline Lizton Unit & Crawfordsville & Crawtordsville & no & not connected & no rule 13 not connected & -86.53697 & 39.89223 \\
\hline Logansport Unit & LaPorte & Monticello & yes & not connected & yes rule13 not connected & -86.39833 & 40.73513 \\
\hline Madison Sub (closed) & Seymour & Madison & yes & not connected & yes rule13 not connected & -85.40840 & 38.76238 \\
\hline Madison Sub (new) & Seymour & Madison & no & connected & no rule 13 connected & -85.42128 & 38.83492 \\
\hline Markle Unit & Fort Wayne & Blufftion & no & not connected & no rule13 not connected & -85.34332 & 40.82975 \\
\hline Martinsville Unit & Seymour & Bloomington & no & not connected & no rule13 not connected & -86.37913 & 39.41078 \\
\hline Medaryville Unit & LaPorte & Winamac & no & not connected & no rule13 not connected & -86.89295 & 41.14329 \\
\hline
\end{tabular}




\begin{tabular}{|c|c|c|c|c|c|c|c|}
\hline Michigan City Unit & LaPorte & LaPorte & yes & not connected & yes rule13 not connected & -86.90845 & 41.67905 \\
\hline Miller Unit & LaPorte & Gary & yes & not connected & yes rule 13 not connected & -87.30973 & 41.58628 \\
\hline Mishawaka Unit & LaPorte & Plymouth & yes & not connected & yes rule13 not connected & -86.15130 & 41.65408 \\
\hline Monroe Unit & Fort Wayne & Bluffton & no & not connected & no rule13 not connected & -84.95620 & 40.74757 \\
\hline Monticello Salt Dome & LaPorte & Monticello & no & not connected & no rule13 not connected & -86.74459 & 40.70147 \\
\hline Monticello Sub & LaPorte & Monticello & no & not connected & no rule 13 not connected & -86.75215 & 40.72583 \\
\hline Mount Vernon Satelite & Vincennes & Evansville & no & not connected & no rule 13 not connected & -87.91742 & 37.92195 \\
\hline Muncie Unit & Greenfield & Albany & yes & connected & yes rule 13 connected & -85.36702 & 40.24028 \\
\hline New Albany Unit & Seymour & Falls City & yes & connected & yes rule13 connected & -85.82133 & 38.30925 \\
\hline New Castle Unit & Greenfield & Centerville & no & not connected & no rule13 not connected & -85.38698 & 39.87642 \\
\hline New Gary Sub & LaPorte & Gary & yes & not connected & yes rule13 not connected & -87.24615 & 41.59512 \\
\hline New Haven Unit & Fort Wayne & Fort Wayne & yes & connected & yes rule13 connected & -84.99467 & 41.06857 \\
\hline New Paris Unit & Fort Wayne & Goshen & no & not connected & no rule13 not connected & -85.87148 & 41.45160 \\
\hline Newport Unit & Crawfordsville & Veedersburg & no & not connected & no rule13 not connected & -87.41110 & 39.86968 \\
\hline North Manchester Unit & Fort Wayne & Warsaw & no & not connected & no rule13 not connected & -85.79533 & 40.99758 \\
\hline North Vernon Unit & Seymour & Madison & no & not connected & no rule13 not connected & -85.63975 & 39.02798 \\
\hline Orland Unit & Fort Wayne & Angola & no & not connected & no rule13 not connected & -85.17543 & 41.65122 \\
\hline Paoli Sub & Vincennes & Paoli & no & connected & no rule13 connected & -86.46447 & 38.56323 \\
\hline Paxton Unit & Vincennes & Linton & no & not connected & no rule13 not connected & -87.39995 & 39.02408 \\
\hline Penntown Unit & Seymour & Aurora & no & not connected & no rule 13 not connected & -85.10188 & 39.28438 \\
\hline Peru Unit & Fort Wayne & Wabash & no & not connected & no rule 13 not connected & -86.12740 & 40.79350 \\
\hline Petersburg Unit & Vincennes & Petersburg & no & connected & no rule13 connected & -87.28700 & 38.50253 \\
\hline Plainfield Unit & Crawfordsville & Cloverdale & yes & connected & yes rule13 connected & -86.39420 & 39.69112 \\
\hline Plymouth Sub & LaPorte & Plymouth & no & not connected & no rule 13 not connected & -86.30215 & 41.41657 \\
\hline Porter Maintenance facility & Toll Road District & Toll Road & yes & not connected & yes rule13 not connected & -87.18375 & 41.58152 \\
\hline Portland Unit & Greenfield & Albany & no & not connected & no rule 13 not connected & -85.02760 & 40.42023 \\
\hline Poseyville Unit & Vincennes & Evansville & no & connected & no rule13 connected & -87.77387 & 38.17018 \\
\hline Princeton Unit & Vincennes & Petersburg & no & connected & no rule13 connected & -87.61103 & 38.35663 \\
\hline Remington Salt Storage(1-65/US24) & LaPorte & Renesselaer & no & not connected & no rule13 not connected & -87.11718 & 40.76630 \\
\hline Rensselaer Sub (new) & LaPorte & Rensselaer & no & connected & no rule13 connected & -87.13934 & 40.94605 \\
\hline Rensselaer Sub (old) & LaPorte & Rensselaer & no & connected & no rule 13 connected & -87.14537 & 40.94550 \\
\hline Rochester Unit & LaPorte & Winamac & no & not connected & no rule13 not connected & -86.24160 & 41.06420 \\
\hline Romney Unit & Crawfordsville & Crawtordsville & no & not connected & no rule13 not connected & -86.90673 & 40.23098 \\
\hline Roselawn Unit & LaPorte & Rensselaer & no & not connected & no rule 13 not connected & -87.27688 & 41.14370 \\
\hline Rushville Unit & Greenfield & Greenfieid & no & not connected & no rule 13 not connected & -85.48338 & 39.59874 \\
\hline Salem Unit & Seymour & Falls City & no & not connected & no rule13 not connected & -86.17288 & 38.61957 \\
\hline Salisbury Road Unit & Greenfield & Centerville & yes & connected & yes rule 13 connected & -84.94057 & 39.86688 \\
\hline Scottsburg Unit & Seymour & Madison & no & connected & no rule 13 connected & -85.79498 & 38.68482 \\
\hline Sellersburg Unit & Seymour & Falls City & yes & connected & yes rule 13 connected & -85.75246 & 38.34897 \\
\hline
\end{tabular}




\begin{tabular}{|c|c|c|c|c|c|c|c|}
\hline Seymour District & Seymour & Columbus & yes & connected & yes rule13 connected & -85.86137 & 38.96105 \\
\hline Shelburn Unit & Vincennes & Linton & no & not connected & no rule13 not connected & -87.38843 & 39.19505 \\
\hline Shelbyville Unit & Greenfield & Greenfield & yes & connected & yes rule13 connected & -85.77203 & 39.54858 \\
\hline Shipshewana & Fort Wayne & Angola & no & not connected & no rule13 not connected & -85.55447 & 41.66283 \\
\hline Shoals Unit & Vincennes & Paoli & no & not connected & no rule13 not connected & -86.81680 & 38.68473 \\
\hline South Bend Unit & LaPorte & Plymouth & yes & not connected & yes rule13 not connected & -86.32210 & 41.68365 \\
\hline Spencer Unit & Seymour & Bloomington & no & not connected & no rule13 not connected & -86.72815 & 39.28415 \\
\hline Steuben Maintenance facility & Toll Road District & Angola & no & not connected & no rule13 not connected & -85.11508 & 41.75210 \\
\hline Tell City Sub & Vincennes & Tell City & no & connected & no rule13 connected & -86.62170 & 38.05972 \\
\hline Terre Haute Sub & Crawfordsville & Terre Haute & yes & connected & yes rule13 connected & -87.32953 & 39.42745 \\
\hline Tipton Sub & Greenfield & Tipton & no & connected & no rule13 connected & -86.05382 & 40.28125 \\
\hline Toll Road District & Toll Road District & Toll Road & yes & not connected & yes rule13 not connected & -86.06230 & 41.73049 \\
\hline Trenton Unit & Greenfield & Albany & no & not connected & no rule13 not connected & -85.23190 & 40.45062 \\
\hline Unit 2 (Tibbs) & Greenfield & Indianapolis & yes & connected & yes rule13 connected & -86.21478 & 39.76528 \\
\hline Unit 3 (71st St) & Greenfield & Indianapolis & yes & not connected & yes rule13 not connected & -86.29342 & 39.88183 \\
\hline Unit 4 (65th St) & Greenfield & Indianapolis & yes & connected & yes rule 13 connected & -86.07813 & 39.87813 \\
\hline Unit 5 (Madison) & Greenfield & Indianapolis & yes & connected & yes rule13 connected & -86.15597 & 39.75205 \\
\hline US 27 South Unit & Fort Wayne & Fort Wayne & yes & not connected & yes rule13 not connected & -85.09222 & 40.98998 \\
\hline Valparaiso Unit (closed) & LaPorte & LaPorte & yes & not connected & yes rule 13 not connected & -87.00415 & 41.44878 \\
\hline Veedersburg Sub & Crawfordsville & Veedersburg & no & not connected & no rule13 not connected & -87.24873 & 40.10413 \\
\hline Versailles Unit & Seymour & Madison & no & not connected & no rule13 not connected & -85.26045 & 39.04863 \\
\hline Vincennes District Sub & Vincennes & Petersburg & $\overline{\text { no }}$ & connected & no rule13 connected & -87.53003 & 38.62882 \\
\hline Vincennes District Unit & Vincennes & Petersburg & no & connected & no rule13 connected & -87.53117 & 38.62955 \\
\hline Wabash Sub & Fort Wayne & Wabash & yes & connected & yes rule13 connected & -85.80355 & 40.82470 \\
\hline Wanatah Unit & LaPorte & LaPorte & no & not connected & no rule 13 not connected & -86.90177 & 41.43468 \\
\hline Warren Unit & Fort Wayne & Bluffton & no & not connected & no rule13 not connected & -85.44017 & 40.66748 \\
\hline Warsaw Sub & Fort Wayne & Warsaw & no & not connected & no rule13 not connected & -85.89550 & 41.27053 \\
\hline Washington Unit & Vincennes & Petersburg & yes & connected & yes rule 13 connected & -87.17182 & 38.64607 \\
\hline Waterloo Unit & Fort Wayne & Angola & no & not connected & no rule13 not connected & -85.03465 & 41.43775 \\
\hline Westfield Unit & Greenfield & Tipton & yes & not connected & yes rule 13 not connected & -86.17145 & 40.04080 \\
\hline Winamac Sub & LaPorte & Winamac & no & connected & no rule 13 connected & -86.60480 & 41.07888 \\
\hline Winchester Unit & Greenfield & Albany & no & connected & no rule13 connected & -84.99430 & 40.17255 \\
\hline
\end{tabular}


APPENDIX D 


\section{List of Facilities, by District, Within and Outside MS4 Areas}

Within MS4

Crawfordsville

Crawfordsville District

Crawfordsville Sub \& Unit

Terre Haute Sub \& Unit

Frankfort Sub \& Unit

Plainfield Unit

Ft. Harrison Unit

Lafayette Unit

Lebanon Unit

\section{Fort Wayne}

Fort Wayne District

Fort Wayne Sub \& Unit

Goshen Sub

Elkhart Sub \& Unit

Wabash Sub \& Unit

Angola Sub

New Haven Unit

U.S. 27 South Unit
Outside MS4

Carbondale

Fowler Sub \& Unit

Ashboro Unit

Romney Unit

Lizton Unit

Bainbridge Unit

Veedersburg Sub \& Unit

Bloomingdale Unit

Newport Unit

Cloverdale Sub \& Unit
New Paris Unit

Markle Unit

N. Manchester Unit

Waterloos Unit

Orland Unit

Monroe Unit

Warsaw Unit

Laud Unit

Brimfield Unit

Shipshewanna Unit

Peru Unit

Bluffton Sub

Warren Unit

Gas City Unit

\section{Greenfield}

Greenfield District

Greenfield Sub

Unit 2 (Tibbs)

Unit $4\left(65^{\text {th }} \mathrm{St}\right.$.)

Unit 5 (Madison)

Anderson Unit

Shelbyville Unit

Richmond Unit

Alexandria Unit

Muncie Unit
Fortville Unit

Rushville Unit

Rushville Unit

Centerville Sub

Cambridge City Unit

New Castle Unit

Liberty Unit

Trenton Unit

Portland Unit

Westchester Unit 


\section{List of Facilities, by District, Within and Outside MS4 Areas (continued) \\ $\underline{\text { Inside MS4 }}$ \\ $\underline{\text { Outside MS4 }}$}

Greenfield District (continued)

Indianapolis Sub \& 2 Units

Alexandria Unit

Unit 3 ( $71^{\text {st }}$ St.)

Albany Sub

Kokomo Unit

Tipton Sub

Westfield Unit

$\underline{\text { LaPorte }}$

LaPorte District

LaPorte Sub \& Unit

New Gary Sub

Valparaiso Unit (closed)

Chesterton

Logansport Unit

South Bend Unit

Mishawaka Unit

Old Gary Sub

Crown Point Unit

Miller Unit

Michigan City Unit

Monticello Salt Dome

Flora Unit

Medaryville Unit

Monticello Sub

Hanna Unit (near closure)

Roselawn Unit

Kentland Unit

Rochester Unit

Plymouth Unit

Wanatah Unit

Rensselaer Sub

Winamac Sub

Seymour

Seymour District

Bloomington Sub \& Unit

Columbus Sub \& Unit

Sellersburg Sub \& Unit

New Albany Unit

Greensburg Unit

Madison Sub
Amity Unit

North Vernon Unit

Versailles Unit

Salem Unit

Brookville Unit

Spencer Unit

Brookville Unit

Aberdeen Unit

Penntown Unit

Martinsville Unit

Beanblossom Unit

Brownstown

Aurora Sub

Scottsburg Unit

Corydon Unit

New Madison sub (JPG) 
List of Facilities, by District, Within and Outside MS4 (continued)

Within MS4

Vincennes

Jasper Unit

Evansville Sub \& Unit 2

Evansville Unit 1

Chandler Unit

Washington Unit

Bedford Unit $\underline{\text { Outside MS4 }}$

\author{
Shoals Unit \\ Grantsburg Unit \\ Paxton Unit \\ Birdseye Unit \\ Linton Sub \\ Bloomfield Unit \\ Dale Sub \& Unit \\ Chrisney Unit \\ Poseyville Unit \\ New Paoli Sub \& Unit \\ Tell City Sub \\ Derby Unit \\ Vincennes District \\ Vincennes Sub \& Unit \\ Petersburg Unit \\ Princeton Unit
}

\section{Toll Road}

Lake Maintenance

Porter Maintenance

Elkhart Maintenance

Toll Road District
LaGrange Maintenance

Steuben Maintenance

LaPorte Maintenance 
APPENDIX E 
APPENDIX F

(www.ecn.purdue.edu/CMTI/INDOT/Citywwt.xls) 


\section{KEY}

MS4 with Combined Sewer POTW

12 MS4 without Combined Sewer POTW

$\square$ Non-MS4 POTWs 


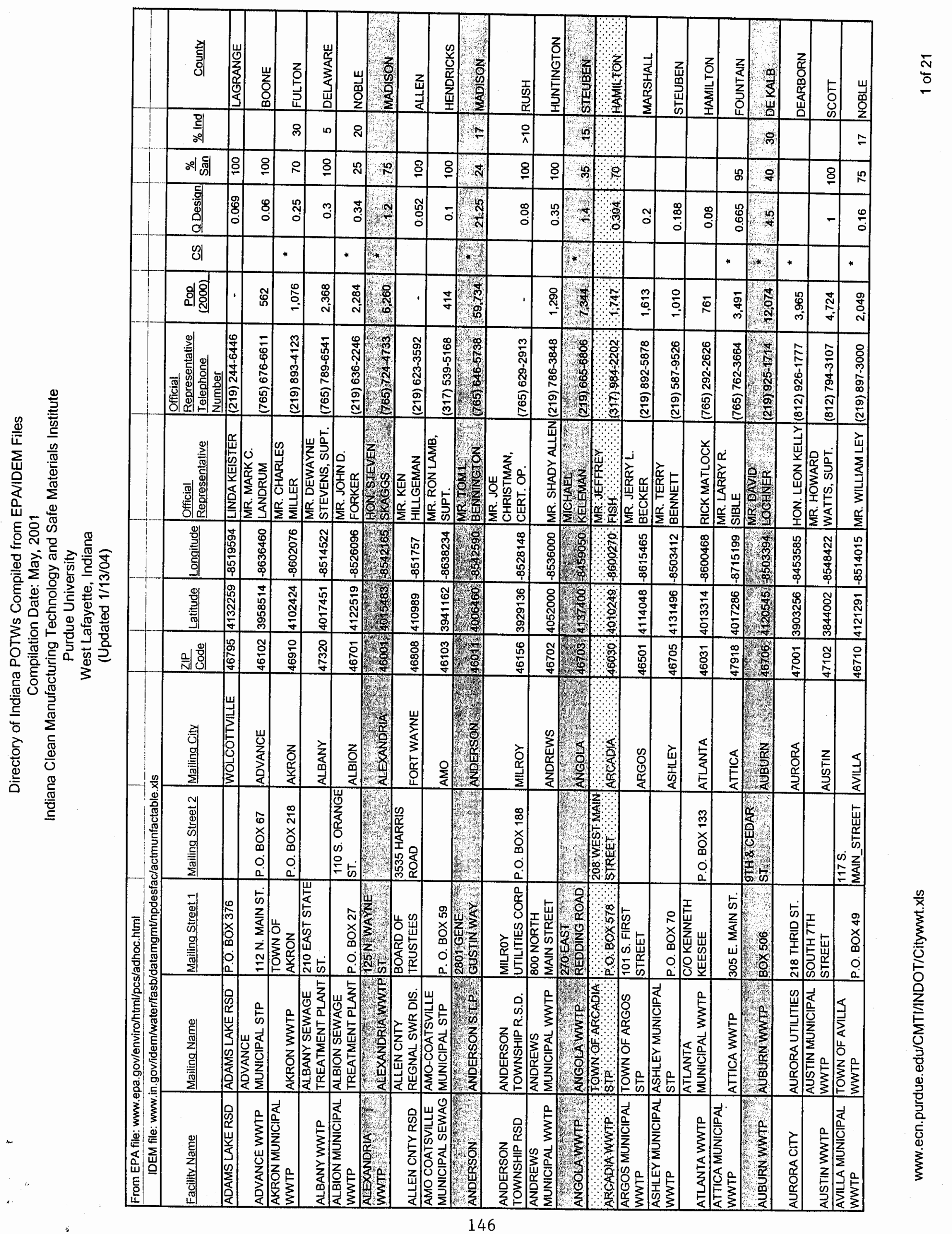


Directory of Indiana POTWs Compiled from EPA/IDEM Files

Compilation Date: May, 2001

Indiana Clean Manufacturing Technology and Safe Materials Institute

Purdue University

West Lafayette, Indiana

(Updated 1/13/04)

\begin{tabular}{|c|c|c|c|c|c|c|c|c|c|c|c|c|c|c|c|}
\hline Facility Name & Mailing Name & Mailing Street 1 & Mailing Street 2 & Mailing City & ZIP & Latitude & Longitude & $\begin{array}{l}\text { Official } \\
\text { Representative }\end{array}$ & $\begin{array}{l}\text { Official } \\
\text { Representative } \\
\text { Telephone } \\
\text { Number } \\
\end{array}$ & $\frac{P 0 p}{(2000)}$ & $\underline{\mathrm{CS}}$ & Q Design & $\underline{\frac{\%}{\operatorname{San}}}$ & $\%$ ind & County \\
\hline $\begin{array}{l}\text { BAINBRIDGE } \\
\text { MUNICIPAL WWTP }\end{array}$ & $\begin{array}{l}\text { BAINBRIDGE } \\
\text { MUNICIPAL STP }\end{array}$ & P. О. BOX 343 & & BAINBRIDGE & 46105 & 3945147 & -8647548 & $\begin{array}{l}\text { MR. JEFFERY S. } \\
\text { KIGER, PRES. }\end{array}$ & (765) 522-6238 & 743 & & 0.057 & 100 & & PUTNAM \\
\hline BARGERSVACLE & BARGERSVHLE & $\begin{array}{l}5711 . \text { W SMIFH } \\
\text { VALLLEY ROAB }\end{array}$ & & BARGERSVILLE & 47106 & 3931174 & 8610394 & MR SOHN SCOTI & $(31,-4)<2-5115$ & 2,20 & & 0144 & 100 & & jot \\
\hline BASS LAKE CD & BASS LAKE CD & P.O. BOX 461 & & KNOX & 46534 & 4114147 & -8636157 & MR. TOM JORDAN & & - & & 0.2916 & & & STARKE \\
\hline BATESVILLE WWTP & BATESVILLE WWTP & $\begin{array}{l}200 \text { SOUTH } \\
\text { MAIN ST }\end{array}$ & & BATESVILLE & 47006 & 3917496 & -8514272 & $\begin{array}{l}\text { MR. RANDY } \\
\text { GIBBS, SUPT. }\end{array}$ & (812) 934-5338 & 6,033 & & 1.23 & 100 & 50 & RIPLEY \\
\hline $\begin{array}{l}\text { BATALEGROUND } \\
\text { MU NICTAL WWTP }\end{array}$ & BATALEGROUND & $P 0 B O \times 303$ & & BATLEGROUND & 47920 & 4030259 & 6650492 & MAR JAYMCMALIN & $(765) \quad 5672603$ & 1,323 & & 0.26 & 100 & & TIP ECANOE \\
\hline BEDEORD WMTTP & BEDFORD CTY & wip & STMATH & BEDFORQ & $4742 \mathrm{t}$ & 3850208 & 863118 & 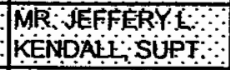 & $(a 12)$ 2 & 13,768 & & 3 & बia & 25: & ULAWRENEE \\
\hline BELLEVILLE CD & BELLLVVILLEE CD & P. O. BOX 209 & & CLAYTON & 46118 & 3940259 & -8627084 & $\begin{array}{l}\text { MR. ROBERT } \\
\text { CHRISTIAN, } \\
\text { CHAIRMAN }\end{array}$ & (317) 745-4928 & - & & 0.095 & 100 & & HENDRICKS \\
\hline \begin{tabular}{|l} 
BERNE MUNICIPAL \\
WWTP SITE 1 \\
\end{tabular} & $\begin{array}{l}\text { BERNE MUNICIPAL } \\
\text { WWTP }\end{array}$ & $\begin{array}{l}343 \text { EAST } 550 \\
\text { SOUTH }\end{array}$ & & BERNE & 46711 & 4040047 & -8456489 & $\begin{array}{l}\text { MR. RON CRIDER, } \\
\text { SUPT. }\end{array}$ & (219) 589-3425 & 4,150 & * & 0.6 & 0 & 20 & ADAMS \\
\hline $\begin{array}{l}\text { BICKNELL } \\
\text { MUNICIPAL WWTP }\end{array}$ & $\begin{array}{l}\text { BICKNELL } \\
\text { MUNICIPAL STP }\end{array}$ & P.O. BOX 127 & 119 E. 2ND ST. & BICKNELL & 47512 & 3845547 & -8718393 & $\begin{array}{l}\text { HON. GORDON } \\
\text { STINEBAUGH, } \\
\text { MAYOR } \\
\end{array}$ & (812) 735-4.636 & 3,378 & & 0.5 & 100 & & KNOX \\
\hline $\begin{array}{l}\text { BIRDSEYE } \\
\text { MUNICIPAL WWTP } \\
\end{array}$ & $\begin{array}{l}\text { BIRDSEYE } \\
\text { MUNICIPAL STP }\end{array}$ & $\begin{array}{l}\text { P.O. BOX } 93 \\
\text { (TOWN HALL) }\end{array}$ & & BIRDSEYE & 47513 & 3817550 & -8641219 & $\begin{array}{l}\text { MR. RON } \\
\text { GROESCHEN }\end{array}$ & (812) 482-3277 & 465 & & 0.08 & 100 & & DUBOIS \\
\hline $\begin{array}{l}\text { BLOOMFIELD } \\
\text { MUNICIPAL WWTP }\end{array}$ & $\begin{array}{l}\text { BLOOMFIELD } \\
\text { MUNICIPAL STP } \\
\end{array}$ & P. О. BOX 411 & & BLOOMFIELD & 47424 & 3901000 & -8658000 & $\begin{array}{l}\text { MR. GARY } \\
\text { BRADFIELD }\end{array}$ & (812) 384-8013 & 2,542 & & 0.22 & 100 & & GREENE \\
\hline BLOOMANGFON & BLOONANGTOA & PLUGHER & $P O B O X+216$ & BLOOMINGTON & 47402 & 3914488 & 8632549 & MR TNN SUPT & $(812) 8704875$ & 34,646 & & $6:$ & 100 & & \\
\hline $\begin{array}{l}\text { BLOOMINGTON, } \\
\text { DILLMAN ROAD } \\
\end{array}$ & $\begin{array}{l}\text { BLOOMINGTON - } \\
\text { SOUTH PLANT }\end{array}$ & $\begin{array}{l}\text { DILLMAN ROAD } \\
\text { STP } \\
\end{array}$ & P.O. BPX 100 & BLOOMINGTON & 47402 & 3905366 & -8632578 & $\begin{array}{l}\text { MR. BILL BARDES, } \\
\text { PLT. MGN. }\end{array}$ & $(812) 824-4900$ & 34,646 & & 15 & 100 & 25 & MONROE \\
\hline \begin{tabular}{|l} 
BLUFFTON \\
MUNICIPAL STP \\
\end{tabular} & $\begin{array}{l}\text { BLUFFTON } \\
\text { MUNICIPAL STP }\end{array}$ & $\begin{array}{l}702 \text { NORTH } \\
\text { MAIN STREET }\end{array}$ & & BLUFFTON & 46714 & 4044514 & -8510196 & $\begin{array}{l}\text { MR. ROBERT } \\
\text { MOHLER } \\
\end{array}$ & (219) 824-5430 & 9,536 & * & 2.6 & 94 & 10 & WELLS \\
\hline $\begin{array}{l}\text { BOONVILLE } \\
\text { MUNICIPAL STP } \\
\end{array}$ & \begin{tabular}{|l} 
BOONVILLE \\
MUNICIPAL WWTP
\end{tabular} & $\begin{array}{l}\text { CITY HALL P.O. } \\
\text { BOX } 585\end{array}$ & . & BOONVILLE & 47601 & 3802541 & -8717207 & $\begin{array}{l}\text { MR. RANDALL } \\
\text { ALLEN, CERT. } \\
\text { OPER. }\end{array}$ & (812) 897-2118 & 6,834 & * & 1.44 & & & WARRICK \\
\hline $\begin{array}{l}\text { BORDEN } \\
\text { MUNICIPAL WWTP } \\
\end{array}$ & $\begin{array}{l}\text { NEW PROVIDENCE } \\
\text { MUNICIPAL WWTP }\end{array}$ & P. O. BOX 125 & $\begin{array}{l}\text { BORDEN TOWN } \\
\text { HALL }\end{array}$ & BORDEN & 47106 & 3827431 & -8555443 & MR. PAT KELLY & $(812) 967-3014$ & 818 & & 0.14 & 100 & & CLARK \\
\hline $\begin{array}{l}\text { BOSWELL } \\
\text { MUNICIPAL WWTP }\end{array}$ & $\begin{array}{l}\text { BOSWELL } \\
\text { MUNICIPAL STP }\end{array}$ & $\begin{array}{l}106 \text { N. ADAMS, } \\
\text { P.O. BOX } 223\end{array}$ & & BOSWELL & 47921 & 4030497 & -8722307 & $\begin{array}{l}\text { MR. JAMES WIT, } \\
\text { CERT. OPER. }\end{array}$ & (765) 869-5020 & 827 & & 0.13 & 100 & & BENTON \\
\hline $\begin{array}{l}\text { BOURBON } \\
\text { MUNICIPAL WWTP }\end{array}$ & $\begin{array}{l}\text { TOWN OF } \\
\text { BOURBON STP }\end{array}$ & $\begin{array}{l}104 \text { EAST PARK } \\
\text { AVE. }\end{array}$ & & BOURBON & 46504 & 4117540 & -8607000 & $\begin{array}{l}\text { MR. MARVIN } \\
\text { MARTIN }\end{array}$ & (219) 342-2574 & 1,691 & & 0.28 & 100 & $=$ & MARSHALL \\
\hline $\begin{array}{l}\text { BRAZIL MUNICIPAL } \\
\text { STP }\end{array}$ & $\begin{array}{l}\text { BRAZIL MUNICIPAL } \\
\text { STP }\end{array}$ & $\begin{array}{l}203 \text { EAST } \\
\text { NATIONAL AVE }\end{array}$ & & BRAZIL & 47834 & 3928591 & -8706185 & SHIRLEY JOLLY & $(812)$ 448-8146 & 8,188 & \# & 1.1 & 90 & & CLAY \\
\hline BREMEN WWTP & BREMEN WWTP & $\begin{array}{l}104 \text { WEST } \\
\text { PLYMOUTH ST. }\end{array}$ & & BREMEN & 46506 & 4127070 & -8610190 & $\begin{array}{l}\text { MR. WILLIAM } \\
\text { REED }\end{array}$ & $(219)$ 546-3829 & 4,486 & * & 1.3 & 75 & 20 & MARSHALL \\
\hline
\end{tabular}


Purdue University

West Lafayette, Indiana

(Updated 1/13/04)

\begin{tabular}{|c|c|c|c|c|c|c|c|c|c|c|c|c|c|c|c|}
\hline Facility Name & Mailing Name & Mailing Street 1 & Mailing Street 2 & Mailing City & $\frac{Z 1 P}{\text { Code }}$ & Latitude & Longitude & $\begin{array}{l}\text { Official } \\
\text { Representative }\end{array}$ & \begin{tabular}{|l} 
Official \\
Representative \\
Telephone \\
Number \\
\end{tabular} & $\frac{P o p}{(2000)}$ & $\underline{C S}$ & Q Design & $\underline{\frac{\%}{\operatorname{San}}}$ & $\%$ Ind & County \\
\hline MRISTOL & BRISTOL & Po Box 305 & $\begin{array}{l}130 \text { WEST } \\
\text { VISTUA ST }\end{array}$ & BRISTOK & 46507 & 4143078 & 8549554 & JOAN SUPPER & (z) 19$) 848-7931$ & 1382 & & 0.5 & 100 & & ELLKHART \\
\hline $\begin{array}{l}\text { BROOK MUNICIPAL } \\
\text { WWTP }\end{array}$ & $\begin{array}{l}\text { BROOK MUNICIPAL } \\
\text { WWTP }\end{array}$ & P. O. BOX 182 & 223 W. MAIN ST. & BROOK & 47922 & 4051500 & -8721400 & $\begin{array}{l}\text { MR. TOM } \\
\text { CARROLL }\end{array}$ & (219) 275-6181 & 1,062 & & 0.1 & 100 & & NEWTON \\
\hline BROONLYN WWTT & BROAKL YN & To N MAINST & & BROQKL Y & $46+1$ & उэsद 180 & 2622060 & WAR KIERANF: & (317) 83177. & 1545 & & 024 & 100 & & MORSAN \\
\hline $\begin{array}{l}\text { BROOKSTON } \\
\text { MUNICIPAL WWTP }\end{array}$ & BROOKSTON WWTP & P. O. BOX 238 & $\begin{array}{l}205 \text { E. THIRD } \\
\text { ST. }\end{array}$ & BROOKSTON & 47923 & 4035340 & -8651516 & $\begin{array}{l}\text { MR. MAXL. } \\
\text { ELDRIDGE }\end{array}$ & (765) 563-6412 & 1,717 & & 0.2 & & & WHITE \\
\hline $\begin{array}{l}\text { BROOKVILLE TOWN } \\
\text { HAL,L }\end{array}$ & $\begin{array}{l}\text { BROOKVILLE } \\
\text { MUNICIPAL STP }\end{array}$ & 634 MAIN ST. & & BROOKVILLE & 47012 & 3925000 & -8501000 & $\begin{array}{l}\text { MR. JOHN M. } \\
\text { GINDLING }\end{array}$ & (765) 647-5224 & 2,652 & & 0.71 & 0.95 & & FRANKLIN \\
\hline $\begin{array}{l}\text { BROWNSBURG } \\
\text { WWTP }\end{array}$ & $\begin{array}{l}\text { BROWNSBURG } \\
\text { WWIP }\end{array}$ & $\begin{array}{l}80 \text { E VERMONT } \\
\text { ST }\end{array}$ & (1) & BROWNSBURG, & 46112 & 3950321 & 8624297 & $\begin{array}{l}\text { KATM GEEN } \\
\text { DILON }\end{array}$ & $(317) 852-1114$ & 14,520 & + & 2.4 & 75 & 1 & HENDRICKS \\
\hline \begin{tabular}{|l} 
BROWNSTOWN \\
WASTEWATER T.P.
\end{tabular} & $\begin{array}{l}\text { BROWNSTOWN } \\
\text { WASTEWATER T.P. }\end{array}$ & $\begin{array}{l}200 \text { W. WALNUT } \\
\text { ST. }\end{array}$ & & BROWNSTOWN & 47220 & 3852561 & -8603451 & $\begin{array}{l}\text { MR. SCOTT } \\
\text { HUNSUCKER }\end{array}$ & (812) 358-4274 & 2,978 & & 0.892 & 100 & 6 & JACKSON \\
\hline $\begin{array}{l}\text { BRYANT MUNICIPAL } \\
\text { WWTP }\end{array}$ & $\begin{array}{l}\text { BRYANT MUNICIPAL } \\
\text { WWTP } \\
\end{array}$ & P.O. BOX 115 & & BRYANT & 47326 & 4031437 & -8457228 & $\begin{array}{l}\text { DAVID L. } \\
\text { MCGRAW }\end{array}$ & (765) 369-2064 & 272 & & 0.03 & & & JAY \\
\hline $\begin{array}{l}\text { BUNKER HILL } \\
\text { MUNICIPAL WWTP }\end{array}$ & $\begin{array}{l}\text { BUNKER HILL } \\
\text { MUNICIPAL WWTP }\end{array}$ & P.O. BOX 565 & $\begin{array}{l}144 \mathrm{~W} . \\
\text { BROADWAY }\end{array}$ & BUNKER HILL & 46914 & 4040016 & -8606018 & $\begin{array}{l}\text { MR. DAN JABERG. } \\
\text { PRESIDENT }\end{array}$ & (765) 689-9096 & 987 & & 0.2 & 100 & & MIAMI \\
\hline $\begin{array}{l}\text { BURLINGTON } \\
\text { MUNICIPAL WWTP }\end{array}$ & $\begin{array}{l}\text { BURLINGTON } \\
\text { MUNICIPAL STP }\end{array}$ & P.O. BOX 399 & & BURLINGTON & 46915 & 4028500 & -8623500 & $\begin{array}{l}\text { MR. TED KELLER, } \\
\text { CERT. OPER. } \\
\end{array}$ & (765) 566-3611 & 444 & & 0.1 & 100 & $>10$ & CARROLL \\
\hline $\begin{array}{l}\text { BURNETTSVILLE } \\
\text { WWTP }\end{array}$ & $\begin{array}{l}\text { BURNETTSVILLE } \\
\text { MUNICIPAL STP } \\
\end{array}$ & P. O. BOX 7 & & BURNETTSVILLE & 47926 & 4045032 & -8636333 & MR. JIM SAYLOR & (219) 826-4114 & 373 & & 0.0455 & 100 & & WHITE \\
\hline $\begin{array}{l}\text { BURNS HARBOR } \\
\text { POTW }\end{array}$ & \begin{tabular}{|l|} 
BURNS HARBOR \& \\
BETHLEHEM STEEL
\end{tabular} & WWTP & & BURNS HARBOR & 46304 & 416139 & -870454 & R. A. MACIEL & (219) 787-2712 & 766 & & 0.25 & & & PORTER \\
\hline $\begin{array}{l}\text { BUTLER MUNICIPAL } \\
\text { WWTP }\end{array}$ & $\begin{array}{l}\text { CITY OF BUTLER } \\
\text { STP }\end{array}$ & $\begin{array}{l}201 \text { SOUTH } \\
\text { BROADWAY ST }\end{array}$ & & BUTLER & 46721 & 4125596 & -8451320 & $\begin{array}{l}\text { MR. WM TED } \\
\text { MILLER, SUPT. }\end{array}$ & (219) 868-2805 & 2,725 & $\star$ & 0.4 & 20 & 5 & DE KALB \\
\hline $\begin{array}{l}\text { CAMBRIDGE CITY } \\
\text { WWTP }\end{array}$ & $\begin{array}{l}\text { WESTERN WAYNE } \\
\text { REG SEWER DIST } \\
\end{array}$ & P.O. BOX 303 & $\begin{array}{l}200 \text { SOUTH } \\
\text { PLUM STREET }\end{array}$ & CAMBRIDGE CITY & 47327 & 3948370 & -8509590 & $\begin{array}{l}\text { MS. DARLENE } \\
\text { DRULEY, SUPT. }\end{array}$ & (765) 478-3788 & 2,121 & & 0.804 & 100 & 50 & WAYNE \\
\hline $\begin{array}{l}\text { CAMDEN } \\
\text { MUNICIPAL WWTP }\end{array}$ & $\begin{array}{l}\text { TOWN OF CAMDEN } \\
\text { STP }\end{array}$ & P.O. BOX 105 & & CAMDEN & 46917 & 4036000 & -8632000 & $\begin{array}{l}\text { MR. JERRY } \\
\text { SNAVELY }\end{array}$ & (219) 686-2121 & 582 & & 0.09 & 100 & $>10$ & CARROLL \\
\hline $\begin{array}{l}\text { CAMPBELLSBURG } \\
\text { MUNICIPAL WWTP }\end{array}$ & $\begin{array}{l}\text { CAMPBELLSBURG } \\
\text { WWTP }\end{array}$ & P.O. BOX 207 & & CAMPBELLSBURG & 47108 & 3839239 & -8616245 & $\begin{array}{l}\text { MR. JACK } \\
\text { HEDRICK, PRES. }\end{array}$ & $(812) 755-4878$ & 578 & & 0.08 & 100 & & WASHINGTON \\
\hline $\begin{array}{l}\text { CARBON } \\
\text { MUNICIPAL STP }\end{array}$ & $\begin{array}{l}\text { CARBON } \\
\text { MUNICIPAL_STP }\end{array}$ & P.O. BOX 338 & TOWN HALL & CARBON & 47837 & 3936179 & -8705586 & $\begin{array}{l}\text { MR. ERNEST F. } \\
\text { EGLOFF }\end{array}$ & $(812) 448-8235$ & 334 & & 0.025 & 100 & & CLAY \\
\hline $\begin{array}{l}\text { CARLISLE } \\
\text { MUNICIPAL WWTP }\end{array}$ & $\begin{array}{l}\text { CARLISLE } \\
\text { MUNICIPAL STP }\end{array}$ & P.O. BOX 277 & & CARLISLE & 47838 & 3857400 & -8724000 & $\begin{array}{l}\text { MR. JOHN } \\
\text { MONTGOMERY }\end{array}$ & (812) 398-2341 & 2,660 & & 0.351 & & & SULLIVAN \\
\hline GARMEWWWTP & $\begin{array}{l}\text { GARMAEL MU } \\
\text { WW }\end{array}$ & CATYOF & $\begin{array}{l}\text { ONE QIVIG } \\
\text { SQUARE }\end{array}$ & CARMAEL & 46032 & 3955384 & 8604426 & 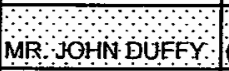 & $(317) 51 \mathrm{a} 2634$ & 37,33 & & 888 & 100 & 5 & HAMII ON \\
\hline $\begin{array}{l}\text { CARTHAGE } \\
\text { MUNICIPAL WWTP }\end{array}$ & CARTHAGE WWTP & P.O. BOX 26. & $\begin{array}{l}\begin{array}{l}\text { WEST FIRST } \\
\text { STREET }\end{array} \\
\end{array}$ & CARTHAGE & 46115 & 3943390 & -8534547 & JAY POWER & (317) 565-6580 & 928 & & 0.15 & 100 & & RUSH \\
\hline $\begin{array}{l}\text { CENTER POINT } \\
\text { TOWN OF }\end{array}$ & $\begin{array}{l}\text { CENTER POINT } \\
\text { WASTEWATER } \\
\text { PLANT } \\
\end{array}$ & $\begin{array}{l}\text { C/OBROWN } \\
\text { ENGINEERING } \\
\text { SERVICES }\end{array}$ & $\mathrm{RR} \# 2, \mathrm{BO} \times 4$ & CENTER POINT & 47480 & 3924500 & -8703490 & \begin{tabular}{|l|} 
MR. ROGER \\
CAMPBELLLDAVID \\
BROWN
\end{tabular} & (812) 835-5151 & 292 & & 0.055 & 100 & & CLAY \\
\hline
\end{tabular}


Directory of Indiana POTWs Compiled from EPAIDEM Files

Compilation Date: May, 2001

Indiana Clean Manufacturing Technology and Safe Materials Institute

Purdue University

West Lafayette, Indiana

(Updated 1/13/04)

\begin{tabular}{|c|c|c|c|c|c|c|c|c|c|c|c|c|c|c|c|}
\hline Facility Name & Mailing Name & Mailing Street 1 & Mailing Street 2 & Mailing City & ZIP & Latitude & Longitude & $\begin{array}{l}\text { Official } \\
\text { Representative }\end{array}$ & \begin{tabular}{|l|} 
Official \\
Representative \\
Telephone \\
Number \\
\end{tabular} & $\frac{P O p}{(2000)}$ & $\underline{C S}$ & QDesign & $\frac{\%}{\text { San }}$ & \% Ind & County \\
\hline $\begin{array}{l}\text { CENTERVILLE } \\
\text { MUNICIPAL WWTP } \\
\end{array}$ & $\begin{array}{l}\text { TOWN OF } \\
\text { CENTERVILLE STP }\end{array}$ & P. O. BOX 125 & 204 E. MAIN ST. & CENTERVILLE & 47330 & 3949090 & -8500257 & MR. JAY WERKING & (765) 855-5515 & 2,427 & & 0.5 & 100 & $>1$ & WAYNE \\
\hline $\begin{array}{l}\text { CHALMERS } \\
\text { MUNICIPAL STP }\end{array}$ & $\begin{array}{l}\text { CHALMERS } \\
\text { MUNICIPAL STP } \\
\end{array}$ & P.O. BOX 827 & & CHALMERS & 47929 & 4038096 & -8652056 & $\begin{array}{l}\text { MR. PERRY } \\
\text { HUGHES }\end{array}$ & (219) 984-5494 & 513 & & 0.09 & 100 & & WHITE \\
\hline CHANDLER MUNICPAL WWTP & $\begin{array}{l}\text { GHANDLER } \\
\text { MUNAICIPAL STP }\end{array}$ & CoNST IT & & CHANDER: & 4769 & 3802025 & 8723025 & $\begin{array}{l}\text { MARAYWHKE } \\
\text { CERT QPER }\end{array}$ & (68) 2925696 & $3 ; 094$ & & 07 & 100 & & WARRICK \\
\hline $\begin{array}{l}\text { CHARLESTOWN } \\
\text { MUNICIPAL WWTP }\end{array}$ & $\begin{array}{l}\text { CHARLESTOWN } \\
\text { MUNICIPAL WWTP }\end{array}$ & $\begin{array}{l}\text { CITY OF } \\
\text { CHARLESTOWN }\end{array}$ & $\begin{array}{l}304 \text { MAIN } \\
\text { CROSS ST }\end{array}$ & CHARLESTOWN & 47111 & 3826101 & -8539218 & $\begin{array}{l}\text { BOB HALL, } \\
\text { MAYOR }\end{array}$ & (812) 256-7131 & 5,993 & & 0.689 & 100 & & CLARK \\
\hline $\begin{array}{l}\text { CHESTERFIELD } \\
\text { MUNICIPAL WWTP }\end{array}$ & $\begin{array}{l}\text { CHESTERFIELD } \\
\text { MUNICIPAL STP }\end{array}$ & P. $0 . \mathrm{BOX95}$ & Wrats & CHESTEREE OD & 46611 & 4007000 & 8536000 & $\begin{array}{l}\text { MRDQN } \\
\text { GAREENIER }\end{array}$ & W & 2,969 & 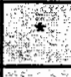 & ascantens & 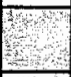 & & MADISON \\
\hline $\begin{array}{l}\text { CHESTERTON STP } \\
\text { CHE }\end{array}$ & $\begin{array}{l}\text { CHESTERTON } \\
\text { UTILITIES }\end{array}$ & $\begin{array}{l}300 \angle E A G U E \\
\text { EANE }\end{array}$ & S & 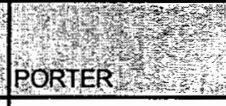 & 46304 & 4137090 & 8703500 & $\begin{array}{l}\text { CHERY SCULYY } \\
\text { CERA OPER }\end{array}$ & $(219), 926-1032$ & 10,488 & 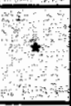 & $\begin{array}{l}275 \\
275\end{array}$ & 86 & $>1$ & PORTER \\
\hline $\begin{array}{l}\text { CHRISNEY } \\
\text { MUNICIPAL WWTP }\end{array}$ & $\begin{array}{l}\text { TOWN OF } \\
\text { CHRISNEY WWTP }\end{array}$ & P.O. BOX 26 & $\begin{array}{l}\text { CHESTNUT } \\
\text { STREET }\end{array}$ & CHRISNEY & 47611 & 3801037 & -8702267 & $\begin{array}{l}\text { MR. JOHN C. } \\
\text { GRAHAM }\end{array}$ & (812) 362-8668 & 544 & & 0.07 & 100 & & SPENCER \\
\hline $\begin{array}{l}\text { CHURUBUSCO } \\
\text { MUNICIPAL WWTP }\end{array}$ & $\begin{array}{l}\text { CHURUBUSCO } \\
\text { WWTP } \\
\end{array}$ & $\begin{array}{l}9380 \text { E. STATE } \\
\text { ROAD } 205 \\
\end{array}$ & & CHURUBUSCO & 46723 & 4113597 & -8518407 & $\begin{array}{l}\text { MR. JAMES } \\
\text { HORNE }\end{array}$ & (219) 693-2943 & 1,666 & & 0.25 & 100 & 21 & WHITLEY \\
\hline $\begin{array}{l}\text { CICEROMUNICIPAL } \\
\text { WW TP }\end{array}$ & CICEROAUNLCIPAL & $\mathrm{PO}, \mathrm{BO} \times 39 \mathrm{~A}$ & T50 W CASS & CiCEBO & 46034 & 400019 & 8601076 & $\begin{array}{l}\text { MR PATR IGKA } \\
\text { COMER SUPT }\end{array}$ & $(311) 9845696$ & 4303 & & 0.5 & 75 & & HAMILTON: \\
\hline $\begin{array}{l}\text { CLARKS HILL } \\
\text { MUNICIPAL WWTP }\end{array}$ & $\begin{array}{l}\text { CLARKS HILL } \\
\text { MUNICIPAL WWTP }\end{array}$ & P. O. BOX 146 & & CLARKS HILL & 47930 & 4014480 & -8643180 & $\begin{array}{l}\text { MR. ALOYISIUS } \\
\text { THOMPSON }\end{array}$ & (765) 523-2215 & 680 & & 0.15 & 100 & & TIPPECANOE \\
\hline $\begin{array}{l}\text { CLARKS } \\
\text { WWTPLE }\end{array}$ & CQ ARKS VILE & AMOE E & & GIARKSVILEE & 47129 & 3817484 & 8546247 & CRAWFORD & $(812) 283-4529$ & 21,400 & & 31 & $10 \theta$ & 10 & CQARK \\
\hline $\begin{array}{l}\text { CLAY CITY } \\
\text { MUNICIPAL WWTP }\end{array}$ & $\begin{array}{l}\text { CLAY CITY } \\
\text { MUNICIPAL WWTP }\end{array}$ & $\begin{array}{l}\text { PRESIDENT OF } \\
\text { TOWN BOARD } \\
\end{array}$ & P.O. BOX 87 & CLAY CITY & 47841 & 3916388 & -8707185 & $\begin{array}{l}\text { MR. RICK } \\
\text { SWEARINGEN, } \\
\text { PRESIDENT } \\
\end{array}$ & (812) 232-6564 & 1,019 & & 0.12 & 100 & & CLAY \\
\hline $\begin{array}{l}\text { CLAYPOOL } \\
\text { MUNICIPAL WWTP }\end{array}$ & $\begin{array}{l}\text { CLAYPOOL } \\
\text { MUNICIPAL STP }\end{array}$ & \begin{tabular}{|l|} 
TOWN HALL \\
(FIRE STATION) \\
\end{tabular} & P.O. BOX 6 & CLAYPOOL & 46510 & 4107400 & -8552500 & $\begin{array}{l}\text { MR. DONALD } \\
\text { MILLER, PRES. }\end{array}$ & (219) 566-2322 & 311 & & 0.05 & 100 & & KOSCIUSKO \\
\hline $\begin{array}{l}\text { CLAYTON } \\
\text { MUNICIPAL WWTP }\end{array}$ & $\begin{array}{l}\text { CLAYTON } \\
\text { MUNICIPAL WWTP }\end{array}$ & P.O. BOX 23 & & CLAYTON & 46118 & 3940541 & -8630489 & $\begin{array}{l}\text { MR. GEORGE } \\
\text { BURNETT, JR. }\end{array}$ & (317) 539-2333 & 693 & & 0.15 & 100 & & HENDRICKS \\
\hline CLEAR CREEK CD & CLEAR CREEK CD & P.O. BOX 134 & & COATESVILLE & 46121 & 3942553 & -8643362 & $\begin{array}{l}\text { MR. DOUG } \\
\text { CLODFELTER }\end{array}$ & (765) $246-6752$ & - & & 0.14 & & & PUTNAM \\
\hline CLINTON & CITY OF CLINTON & 259 VINE ST. & & CLINTON & 47842 & 3939142 & -8723519 & $\begin{array}{l}\text { MR. LARRY } \\
\text { BEARD }\end{array}$ & (765) 832-8891 & 5,126 & * & 1 & 94 & & VERMILLION \\
\hline $\begin{array}{l}\text { CLOVERDALE } \\
\text { MUNICIPAL WWTP }\end{array}$ & \begin{tabular}{|l} 
CLOVERDALE \\
MUNICIPAL WWTP \\
\end{tabular} & P.O. BOX 222 & & CLOVERDALE & 46120 & 3930360 & -8647360 & $\begin{array}{l}\text { MR. THOMAS } \\
\text { TERRY }\end{array}$ & $(765) 795-3350$ & 2,243 & & 0.7 & 100 & & PUTNAM \\
\hline $\begin{array}{l}\text { COLFAX MUNICIPAL } \\
\text { WWTP }\end{array}$ & $\begin{array}{l}\text { COLFAX MUNICIPAL } \\
\text { WWTP }\end{array}$ & P. 0.264 & & COLFAX & 46035 & 4011236 & -8639379 & $\begin{array}{l}\text { MR. BOB } \\
\text { STAMBAUGH, } \\
\text { VICE PRES. }\end{array}$ & (765) 324-2195 & 768 & & 0.11 & 60 & & CLINTON \\
\hline $\begin{array}{l}\text { COLUMBIA GITY } \\
\text { WWTP }\end{array}$ & $\begin{array}{l}\text { COLUUMBIA CITY } \\
\text { MUNICIPAL WWTP }\end{array}$ & CITY HALL & and & COLUMBIA GITY & 46725 & 4108416 & 8529247 & $\begin{array}{l}\text { MR HOWARDE } \\
\text { LOWEN JR }\end{array}$ & $(219), 244-4511$ & 7,077 & * & 19 & 5 & & WHITLEY \\
\hline
\end{tabular}


Purdue University

West Lafayette, Indiana

(Updated 1/13/04)

\begin{tabular}{|c|c|c|c|c|c|c|c|c|c|c|c|c|c|c|c|}
\hline Facility Name & Mailing Name & Mailing Street 1 & Mailing Street 2 & Mailing City & Code & Latitude & Longitude & $\begin{array}{l}\text { Official } \\
\text { Representative }\end{array}$ & $\begin{array}{l}\text { Official } \\
\text { Representative } \\
\text { Telephone } \\
\text { Number } \\
\end{array}$ & $\frac{P o p}{(2000)}$ & $\underline{\mathrm{CS}}$ & $\underline{Q}$ Design & $\underline{\frac{\%}{\operatorname{San}}}$ & $\%$ Ind & County \\
\hline COLUMBUSWWTP & $\begin{array}{l}\text { COLUMBUS CITY } \\
\text { UTHTTES WWTP }\end{array}$ & PO BOX 7987 & & colvisus: & $472 a z$ & 3911521 & 8555131 & $\begin{array}{l}\text { MR HAROLDA } \\
\text { QYYE } \because \because \cdots\end{array}$ & $(812) 376-3725$ & 39059 & $\because$ & 124 & 63 & & BARTHOLONEW \\
\hline $\begin{array}{l}\text { CONNERSVILLE } \\
\text { MUNICIPAL STP }\end{array}$ & $\begin{array}{l}\text { CONNERSVIIEE } \\
\text { UTUUIIIES }\end{array}$ & $\mathrm{PO} 0.80 \times 325$ & 3 & CONNERSVILLE & 47331 & 3937383 & 8508301 & $\begin{array}{l}\text { MR } 1 \text { AROLD J } \\
\text { ELLSON. }\end{array}$ & $(317) 825-9411$ & 15,411 & $*$ & 10.8 & 50 & 32 & FAYETTE \\
\hline $\begin{array}{l}\text { CONVERSE } \\
\text { MUNICIPAL WWTP }\end{array}$ & $\begin{array}{l}\text { CONVERSE } \\
\text { MUNICIPAL STP }\end{array}$ & P. 0.473 & & CONVERSE & 46919 & 4035000 & -8552300 & $\begin{array}{l}\text { MR. BUD } \\
\text { CARTWRIGHT }\end{array}$ & (765) 395-5244 & 1,137 & & 0.25 & 100 & & GRANT \\
\hline $\begin{array}{l}\text { CORUNNA TOWN } \\
\text { OF }\end{array}$ & $\begin{array}{l}\text { CORUNNA } \\
\text { MUNICIPAL WWTP }\end{array}$ & $\begin{array}{l}\text { TOWN OF } \\
\text { CORUNNA }\end{array}$ & $\begin{array}{l}\text { TOWN HALL } \\
\text { P.O.BOX } 62 \\
\end{array}$ & CORUNNA & 46730 & 4126052 & -8509216 & $\begin{array}{l}\text { MR. JEFF } \\
\text { BARTELS }\end{array}$ & (219) 357-5449 & 254 & & 0.024 & 100 & & DE KALB \\
\hline $\begin{array}{l}\text { CORYDON } \\
\text { MUNICIPAL STP }\end{array}$ & $\begin{array}{l}\text { CORYDON } \\
\text { MUNICIPAL STP }\end{array}$ & 113 N. OAK ST. & & CORYDON & 47112 & 3812320 & -8607478 & $\begin{array}{l}\text { MR. FRED K. } \\
\text { CAMMACK }\end{array}$ & $(812) 738-4234$ & 2,715 & & 2 & 100 & 50 & HARRISON \\
\hline $\begin{array}{l}\text { COVINGTON } \\
\text { MUNICIPAL WWTP }\end{array}$ & $\begin{array}{l}\text { COVINGTON } \\
\text { MUNICIPAL STP }\end{array}$ & $\begin{array}{l}13292 \mathrm{ND} \\
\text { STREET } \\
\end{array}$ & P.O. BOX 248 & COVINGTON & 47932 & 4008300 & -8723420 & $\begin{array}{l}\text { MR. TOM } \\
\text { EDWARDS }\end{array}$ & (765) 793-4955 & 2,565 & & 0.35 & 100 & & FOUNTAIN \\
\hline $\begin{array}{l}\text { CRAWFORDSVILEE } \\
\text { WWTP }\end{array}$ & $\begin{array}{l}\text { CRAWFOROSVIELE } \\
\text { MUNICIPAL WWIP }\end{array}$ & GTr BEDG. & $300 \mathrm{E}$ PIKE & CRAWFORDSVILLE & 47933 & 4002460 & 8654440 & MONPHILP Q & $(317) 364-5170$ & 15,243 & $*$ & 34 & 99 & 20 & MONTGOMERY, \\
\hline $\begin{array}{l}\text { CROMWELL } \\
\text { MUNICIPAL WWTP }\end{array}$ & $\begin{array}{l}\text { CROMWELL } \\
\text { MUNICIPAL WWTP }\end{array}$ & \begin{tabular}{|l} 
P.O. BOX 574, \\
200 WATER ST.
\end{tabular} & & CROMWELL & 46732 & 4124469 & -8536033 & MR. CLARK REED & (219) 856-3766 & 452 & & 0.15 & 100 & 33 & NOBLE \\
\hline $\begin{array}{l}\text { CROTHERSVILLE } \\
\text { MUNICIPAL WWTP }\end{array}$ & $\begin{array}{l}\text { CROTHERSVILLE } \\
\text { MUNICIPAL STP } \\
\end{array}$ & $\begin{array}{l}101 \text { W. HOWARD } \\
\text { ST. }\end{array}$ & & CROTHERSVILLE & 47229 & 3847255 & -8550564 & $\begin{array}{l}\text { MR. BILLY } \\
\text { DEATON }\end{array}$ & (812) 793-2540 & 1,570 & $\star$ & 0.47 & 20 & & JACKSON \\
\hline $\begin{array}{l}\text { CROWN POINT } \\
\text { WWTP }\end{array}$ & $\begin{array}{l}\text { CROWN POINT } \\
\text { MUNICIPAL WWTP }\end{array}$ & $\begin{array}{l}101 \mathrm{NORTH} \\
\mathrm{EASTST}\end{array}$ & 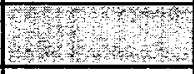 & CROWN POINT & 46307 & 4126060 & 8721804 & BONHENLX: & $(219) 6623255$ & 19,806 & (t) & $\begin{array}{r}0.6 \\
\end{array}$ & 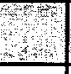 & 1 & GAKE \\
\hline $\begin{array}{l}\text { CULVER MUNICIPAL } \\
\text { WWTP }\end{array}$ & $\begin{array}{l}\text { TOWN OF CULVER } \\
\text { STP }\end{array}$ & $\begin{array}{l}200 \text { E. } \\
\text { WASHINGTON }\end{array}$ & & CULVER & 46511 & 4113060 & -8625180 & $\begin{array}{l}\text { MR. JOE } \\
\text { SHEPPARD }\end{array}$ & (219) 842-2412 & 1,539 & & 0.38 & 100 & & MARSHALL \\
\hline $\begin{array}{l}\text { CUMECLAND } \\
\text { SEWAGE UTLUT }\end{array}$ & CONMBERAND $\triangle \mathrm{QP}$ & 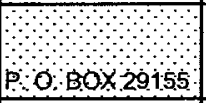 & WASHINGTON: & GUMBERLAND: & 46229 & 3946300 & -8557000 & $\begin{array}{l}\text { RON SUULLANA } \\
\text { TOWN EOUNCI } \\
\text { PRES }\end{array}$ & (31)7) 8944600 & 500 & & 0.538 & 90 & 5 & MARION: \\
\hline $\begin{array}{l}\text { DALE MUNICIPAL } \\
\text { WWIP }\end{array}$ & $\begin{array}{l}\text { TOWN OF DALE } \\
\text { WWTP }\end{array}$ & P.O. BOX 117 & $\begin{array}{l}03 \text { S. } \\
\text { WALLACE ST } \\
\end{array}$ & DALE & 47523 & 3809046 & -8659023 & $\begin{array}{l}\text { FREDERICK } \\
\text { WEBER, PRES. } \\
\end{array}$ & (812) 937-2040 & 1,568 & & 0.444 & 100 & & SPENCER \\
\hline DAN MUICLE & $\begin{array}{l}\text { DANVGLE WAAER } \\
\text { POLLCGRL FACIL }\end{array}$ & $\begin{array}{l}\text { 147 WEST MAIN } \\
\text { STREET }\end{array}$ & $\begin{array}{l}77 \text { NORTH } \\
\text { KENTUCKYST }\end{array}$ & DANVILLE & 46122 & (9) & 8630357 & $\begin{array}{l}\text { KERAN TANSY } \\
\text { CERT OPER }\end{array}$ & $(317) 745-4928$ & $\therefore 658$ & & 12 & $100:$ & & HENORIEKS \\
\hline $\begin{array}{l}\text { DARLINGTON } \\
\text { MUNICIPAL WWTP }\end{array}$ & $\begin{array}{l}\text { DARLINTON } \\
\text { MUNICIPAL WWTP } \\
\end{array}$ & P. O. BOX 578 & & DARLINGTON & 47940 & 4006247 & -8646038 & $\begin{array}{l}\text { MR. RICHARD } \\
\text { SMITH } \\
\end{array}$ & (765) 764-4496 & 854 & & 0.09 & 75 & & MONTGOMERY \\
\hline DARMSTADT WWTP & DARMSTADT WWTP & P. O. 386 & $\begin{array}{l}559 \text { HOING } \\
\text { ROAD } \\
\end{array}$ & EVANSVILLE & 47711 & 3805391 & -8734084 & $\begin{array}{l}\text { MR. BERNHARDT } \\
\text { KAHRE, PRES. }\end{array}$ & (812) 867-1413 & 1,313 & & 0 & & & VANDERBURGH \\
\hline DECATUR WWTP & $\begin{array}{l}\text { CTYY OF QECATUR } \\
\text { STP }\end{array}$ & $\mathrm{CTTHAL}$ & $\begin{array}{l}225 \text { WEST } \\
\text { MONROE ST }\end{array}$ & $\begin{array}{l}\text { GEGATUR } \\
\text { BEG }\end{array}$ & 46733 & 4050530 & 8 & $\begin{array}{l}\text { MON TREDR } \\
\text { HSG }\end{array}$ & (219) $724-4218$ & 9,528 & & 28 & 70 & & ADAMS \\
\hline DELPHI WWTP & $\begin{array}{l}\text { DELPHI MUNICIPAL } \\
\text { WWTP } \\
\end{array}$ & P. O. BOX 8B & RR 2 & DELPHI & 46923 & 4034496 & -8640506 & $\begin{array}{l}\text { MR. RICHARD W. } \\
\text { VAN SICKLE }\end{array}$ & (765) 564-2313 & 3,015 & & 1.5 & 95 & & CARROLL \\
\hline $\begin{array}{l}\text { DEMOTTE } \\
\text { MUNICIPAL WWTP }\end{array}$ & $\begin{array}{l}\text { DEMOTTE } \\
\text { MUNICIPAL WWTP }\end{array}$ & P.O. BOX 368 & 13390 N. 900 W. & DEMOTTE & 46310 & 4112322 & -8713072 & $\begin{array}{l}\text { MR. RICHARD } \\
\text { HIGGINS } \\
\end{array}$ & (219) $987-5350$ & 3,234 & & 0.4 & 100 & & JASPER \\
\hline $\begin{array}{l}\text { DENVER } \\
\text { MUNICIPAL STP }\end{array}$ & $\begin{array}{l}\text { DENVER MUNICIPAL } \\
\text { STP }\end{array}$ & P.O. BOX 45 & & DENVER & 46926 & 4051366 & -8604549 & $\begin{array}{l}\text { MR. BRUCE } \\
\text { MURPHY }\end{array}$ & (765) 985-2765 & 541 & & 0.05 & 100 & & MIAMI \\
\hline $\begin{array}{l}\text { DILLSBORO } \\
\text { MUNICIPAL WWTP }\end{array}$ & $\begin{array}{l}\text { TOWN OF } \\
\text { DILLSBORO STP }\end{array}$ & P. O. BOX 127 & & DILLSBORO & 47018 & 3901080 & -8504322 & $\begin{array}{l}\text { MR. WILLIAM R. } \\
\text { SCHMATZ }\end{array}$ & (812) 432-3243 & 1,436 & & 0.17 & 100 & & DEARBORN \\
\hline
\end{tabular}


Directory of Indiana POTWs Compiled from EPA/IDEM Files

Compilation Date: May, 2001

Indiana Clean Manufacturing Technology and Safe Materials Institute

Purdue University

West Lafayette, Indiana

(Updated 1/13/04)

\begin{tabular}{|c|c|c|c|c|c|c|c|c|c|c|c|c|c|c|c|}
\hline Facility Name & Mailing Name & Mailing Street 1 & Mailing Street 2 & Mailing City & ZIP & Latitude & Longitude & $\begin{array}{l}\text { Official } \\
\text { Representative }\end{array}$ & $\begin{array}{l}\text { Official } \\
\text { Representative } \\
\text { Telephone } \\
\text { Number } \\
\end{array}$ & $\frac{\text { Pop }}{(2000)}$ & $\underline{\mathrm{CS}}$ & Q Design & $\underline{\frac{\%}{\operatorname{San}}}$ & \% ind & County \\
\hline $\begin{array}{l}\text { DUGGER } \\
\text { MUNICIPAL WWTP }\end{array}$ & $\begin{array}{l}\text { DUGGER } \\
\text { MUNICIPAL STP }\end{array}$ & P.O. BOX 146 & & DUGGER & 47848 & 3904324 & -8716572 & $\begin{array}{l}\text { MR. MARK } \\
\text { VAUGHN }\end{array}$ & (812) 648-2173 & 955 & & 0.125 & 100 & & SULLIVAN \\
\hline $\begin{array}{l}\text { DUNKIRK } \\
\text { MUNICIPAL WWTP } \\
\end{array}$ & $\begin{array}{l}\text { DUNKIRK WASTE } \\
\text { WATER DEPT. }\end{array}$ & 131 S. MAIN ST. & & DUNKIRK & 47336 & 4022478 & -8513070 & $\begin{array}{l}\text { MR. GREG } \\
\text { BUCKNER } \\
\end{array}$ & $(765)$ 768-6401 & 2,646 & & 0.7 & 100 & & JAY \\
\hline DUPONT WWTP & DUPONT WWTP & P. O. BOX 116 & & DUPONT & 47231 & 3853139 & -8532087 & $\begin{array}{l}\text { JOSEPH } \\
\text { HOLTGREWE. } \\
\text { CERT. OPER. } \\
\end{array}$ & $(812)$ 265-8328 & 392 & & 0.07 & 100 & & JEFFERSON \\
\hline DYER WWTE & TOWN MEDYYER & $\begin{array}{l}\text { ONE TOWN } \\
\text { SQUARE }\end{array}$ & & DYER: & 46319 & 492958 & 8730571 & MR JEFF & $(219) 865-4224$ & $13,8 Q 5$ & & 5 & 100 & & LAKE: \\
\hline $\begin{array}{l}\text { EAST CHICAGO } \\
\text { SANITARY } \\
\text { DISTRICT }\end{array}$ & $\begin{array}{l}\text { EAST CHICAGO } \\
\text { MUNICIPAL WWIP }\end{array}$ & $\begin{array}{l}\text { BOARG OF } \\
\text { SANTARY } \\
\text { COMM }\end{array}$ & $\begin{array}{l}4525 \\
\text { NOIANAROLIS } \\
\text { BLVD. }\end{array}$ & EAST CHICAGO & 46312 & 4337050 & 8728440 & $\begin{array}{l}\text { HONCROBERT } \\
\text { BASTRICK }\end{array}$ & $(219) 391-8466$ & 32,414 & 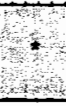 & 15 & 40 & 25 & \\
\hline \begin{tabular}{|l|} 
EAST ENTERPRISE \\
REG. SEW. DIS. \\
\end{tabular} & $\begin{array}{l}\text { EAST ENTERPRISE } \\
\text { REG. SEW. DIS. }\end{array}$ & $\begin{array}{l}\text { TOWN OF EAST } \\
\text { ENTERPRISE }\end{array}$ & P.O. BOX 91 & EAST ENTERPRISE & 47019 & 3853486 & -8458418 & $\begin{array}{l}\text { MS. LINDAF. } \\
\text { ELAM }\end{array}$ & (812) 534-3442 & - & & 0.1 & & & SWITZERLAND \\
\hline EATON CITY OF & $\begin{array}{l}\text { EATON MUNICIPAL } \\
\text { STP }\end{array}$ & P.O. BOX 218 & $\begin{array}{l}600 \text { EAST } \\
\text { HARRIS ST }\end{array}$ & EATON & 47338 & 4020312 & -8522077 & $\begin{array}{l}\text { MR. LARRYL. } \\
\text { BELL }\end{array}$ & (765) 396-3941 & 1,603 & * & 0.3 & 60 & & DELAWARE \\
\hline EDLNBURGA WWTP & EDUNBURGH & Po BOX 65 & & EDINBURGA & 46124 & 3921120 & 8554990 & $\begin{array}{l}\text { MR BLLMEAQ } \\
\text { CERT OPER }\end{array}$ & $(812) 526=3530$ & 4,505 & & 2 & 65 & & jớnson- \\
\hline $\begin{array}{l}\text { ELBERFELD } \\
\text { MUNICIPAL WWTP }\end{array}$ & $\begin{array}{l}\text { ELBERFELD } \\
\text { MUNICIPAL WWTP }\end{array}$ & P.O. BOX 37 & & ELBERFELD & 47613 & 3808148 & -8727288 & $\begin{array}{l}\text { MR. PAUL } \\
\text { FISCHER }\end{array}$ & (812) 983-4365 & 636 & & 0.3 & 100 & & WARRICK \\
\hline $\begin{array}{l}\text { ELDENKUESL, } \\
\text { WWTP }\end{array}$ & MALPARAISO & I66 NGOUNWAY & thy & VALPARAISO & 46383 & 428044 & 8704346 & $\begin{array}{l}\text { MR RIGHARDE } \\
\text { CONDON }\end{array}$ & $(219) 464-4973$ & 27,428 & t) & 6 & 100 & 1 & PORTER \\
\hline $\begin{array}{l}\text { ELIZABETHTTOWN } \\
\text { MUNICIPAL STP } \\
\end{array}$ & $\begin{array}{l}\text { ELIZABETHTOWN } \\
\text { MUNICIPAL STP } \\
\end{array}$ & P.O. BOX 192 & & ELIZABETHTOWN & 47232 & 3908176 & -8549021 & \begin{tabular}{|l|} 
MR. RONALD \\
MIDDLETON
\end{tabular} & (812) 527-2908 & 391 & & 0.08 & 100 & & BARTHOLOMEW \\
\hline ELKHART WWTP & EKHART WWHP & $229 \mathrm{~S} 2 \mathrm{NDST}$ & & ELKHART & 46516 & 4140357 & 8600138 & $\begin{array}{l}\text { ART } \\
\mathrm{GMBC} \text {. }\end{array}$ & $(219) 293-2572$ & 51,874 & 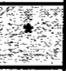 & 20 & 88 & 50 & EHKHAR \\
\hline 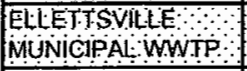 & ELLEJJSULLE & $\begin{array}{l}221 \text { NORTH } \\
\text { SALE ST }\end{array}$ & & EUHETSVILE & 4429 & 3915575 & 863746 & MR JEFH FARMER & $(812) 8761287$ & 5,078 & & 23 & 10 & & MONROE \\
\hline ELNORA WWTP & $\begin{array}{l}\text { ELNORA MUNICIPAL } \\
\text { WWTP }\end{array}$ & P.O. BOX 336 & & ELNORA & 47529 & 3852152 & -8704466 & MR. DAN EMMONS & $(812) 692-5780$ & 721 & & 0.1 & 100 & & DAVIESS \\
\hline ELWOOD WWTP & \begin{tabular}{|l} 
ELWOOD CITY \\
UTILITIES
\end{tabular} & $\begin{array}{l}1601 \text { MAIN } \\
\text { STREET }\end{array}$ & & ELWOOD & 46036 & 4016043 & -8550594 & $\begin{array}{l}\text { MR. C. M. } \\
\text { WASHBURN }\end{array}$ & (765) 552-5512 & 9,737 & * & 3.22 & 5 & 15 & MADISON \\
\hline \begin{tabular}{|l} 
ENGLISH \\
MUNICIPAL WWTP \\
\end{tabular} & \begin{tabular}{|l|} 
ENGLISH \\
MUNICIPAL WWTP \\
\end{tabular} & P.O. BOX 258 & & ENGLISH & 47118 & 3820084 & -8628158 & $\begin{array}{l}\text { MR. MICHAEL } \\
\text { BENHAM, PRES. }\end{array}$ & $(812) 338-2654$ & 673 & & 0.0532 & 100 & & CRAWFORD \\
\hline \begin{tabular}{|l|} 
ETNA GREEN \\
MUNICIPAL WWTP \\
\end{tabular} & $\begin{array}{l}\text { ETNA GREEN } \\
\text { MUNICIPAL WWTP }\end{array}$ & TOWN HALL & P.O. BOX 183 & ETNA GREEN & 46524 & 4116487 & -8603184 & $\begin{array}{l}\text { MR. BARRY } \\
\text { BAKER }\end{array}$ & (219) 858-9076 & 663 & & 0.0455 & 100 & & KOSCIUSKO \\
\hline EVANSVILLE WWTP & $\begin{array}{l}\text { EVANSVILE WEST } \\
\text { WWTP }\end{array}$ & $\begin{array}{l}1500 \text { WATER } \\
\text { WORKSROAD }\end{array}$ & & EVAASVILLE & 47713 & 3757586 & 8732036 & $\begin{array}{l}\text { MR HARRY } \\
\text { EWSON }\end{array}$ & $(812) 426-2820$ & 60,791 & & 18 & & & VANBERBURGH \\
\hline EVANSVILLE WWTP & $\begin{array}{l}\text { EVANSVILLE EAST } \\
\text { WWIP }\end{array}$ & $\begin{array}{l}\text { 1500 WATER } \\
\text { WORKS ROAD }\end{array}$ & & EVANSVULE: & 47713 & 3757160 & 8734057 & $\begin{array}{l}\text { MR WARRY } \\
\text { EAWSON }\end{array}$ & $(812), 26-2820$ & 60,791 & $*$ & 20.6 & & & VANDERBURGH \\
\hline \begin{tabular}{|l|} 
FAIRMOUNT \\
MUNICIPAL WWTP \\
\end{tabular} & $\begin{array}{l}\text { FAIRMOUNT } \\
\text { MUNICIPAL WWTP }\end{array}$ & $\begin{array}{l}214 \mathrm{~W} \\
\text { WASHINGTON }\end{array}$ & & FAIRMOUNT & 46928 & 4025242 & -8538577 & MR. STEVEN DEAL & (765) $948-4313$ & 2,992 & * & 0.55 & 45 & 5 & GRANT \\
\hline FALL CREEK WWTP & FALL CREEK RWD & P.O. BOX 59 & & PENDLETON & 46064 & 3958048 & -8547431 & $\begin{array}{l}\text { MR. JERRY D. } \\
\text { KELLY }\end{array}$ & (765) 778-7544 & 3,873 & & 1.96 & 100 & & MADISON \\
\hline
\end{tabular}


Directory of Indiana POTWs Compiled from EPAIDEM Files

Compilation Date: May, 2001

Indiana Clean Manufacturing Technology and Safe Materials Institute

Purdue University

West Lafayette, Indiana

(Updated 1/13/04)

\begin{tabular}{|c|c|c|c|c|c|c|c|c|c|c|c|c|c|c|c|}
\hline Facility Name & Mailing Name & Mailing Street 1 & Mailing Street 2 & Mailing City & Code & Latitude & Longilude & $\begin{array}{l}\text { Official } \\
\text { Representative }\end{array}$ & $\begin{array}{l}\text { Official } \\
\text { Representative } \\
\text { Telephone } \\
\text { Number } \\
\end{array}$ & $\begin{array}{c}\text { Pop } \\
(2000) \\
\end{array}$ & $\underline{C S}$ & QDesign & $\frac{\%}{\text { San }}$ & $\%$ ind & County \\
\hline $\begin{array}{l}\text { FARMERSBURG } \\
\text { MUNICIPAL WWTP }\end{array}$ & \begin{tabular}{|l} 
FARMERSBURG \\
MUNICIPAL WWTP \\
\end{tabular} & P.O. BOX 468 & & FARMERSBURG & 47850 & 3914461 & -8722034 & MS. MARIE DAVIS & (812) 232-6564 & 1,180 & & 0.15 & 100 & & SULLIVAN \\
\hline FARMLAND WWTP & $\begin{array}{l}\text { TOWN OF } \\
\text { FARMLAND STP }\end{array}$ & P. O. BOX 336 & & FARMLAND & 47340 & 4011104 & -8507091 & $\begin{array}{l}\text { MR. DUANE L. } \\
\text { COX }\end{array}$ & (765) 468-6701 & 1,456 & & 0.165 & 100 & & RANDOLPH \\
\hline $\begin{array}{l}\text { FERDINAND } \\
\text { MUNICIPAL WWTP }\end{array}$ & $\begin{array}{l}\text { TOWN OF } \\
\text { FERDINAND WWTP }\end{array}$ & $\begin{array}{l}\text { TOWN OF } \\
\text { FERDINAND } \\
\end{array}$ & $\begin{array}{l}\text { P.O. BOX } 7,543 \\
\text { W. 5TH ST. } \\
\end{array}$ & FERDINAND & 47532 & 3813163 & -8652059 & $\begin{array}{l}\text { MR. ROGER } \\
\text { SCHAEFER }\end{array}$ & (812) 367-2283 & 2,277 & & 0.338 & 100 & 11 & DUBOIS \\
\hline $\begin{array}{l}\text { FISHERS CHEENEY } \\
\text { CREEK WWTP }\end{array}$ & $\begin{array}{l}\text { FISHERS CHEENEY } \\
\text { CREEK WWTP }\end{array}$ & $\begin{array}{l}\text { FISHERS MUN. } \\
\text { BLDG. }\end{array}$ & $\begin{array}{l}\text { ONE } \\
\text { MUNICIPAL } \\
\text { DRIVE } \\
\end{array}$ & FISHERS & 46038 & 3956034 & -8603544 & MR. MIKE DAVIS & $(317) 849-6260$ & 18,918 & & 1 & 100 & & HAMILTON \\
\hline FISHERSWWTP & FISTERSWWTP & $\begin{array}{l}\text { TMUNACLAL } \\
\text { DRUEE }\end{array}$ & & FISHERS: & 46038 & 395000 & 86020 & MROMKEAVS & $(317) 849660$ & 16918 & & 11 & 100 & 93 & HAMLTONO \\
\hline $\begin{array}{l}\text { FLORA MUNICIPAL } \\
\text { WWTP }\end{array}$ & $\begin{array}{l}\text { FLORA MUNICIPAL } \\
\text { WWTP }\end{array}$ & $\begin{array}{l}507 \text { NORTH } \\
\text { DIVISION ST }\end{array}$ & & FLORA & 46929 & 4032480 & -8631240 & $\begin{array}{l}\text { MR. WILLIAM L. } \\
\text { MCCARTY }\end{array}$ & (219) 967-3005 & 2,227 & & 0.428 & & & CARROLL \\
\hline $\begin{array}{l}\text { FORT BRANCH } \\
\text { SEWAGE DEP } \\
\end{array}$ & $\begin{array}{l}\text { TOWN OF FORT } \\
\text { BRANCH STP }\end{array}$ & P.O. BOX 40 & $\begin{array}{l}210 \text { WEST } \\
\text { LOCUST ST. }\end{array}$ & FORT BRANCH & 47648 & 3814155 & -8734519 & $\begin{array}{l}\text { MR. DONALD } \\
\text { GRIES, PRES. }\end{array}$ & (812) 753-3538 & 2,320 & & 0.655 & 100 & & GIBSON \\
\hline $\begin{array}{l}\text { FORTWAYNE } \\
\text { WWTP }\end{array}$ & $\begin{array}{l}\text { TWAYNECTY } \\
\text { UTUITES }\end{array}$ & WRG PEANT & $\begin{array}{l}2601 \text { DWENGER } \\
\text { AVE }\end{array}$ & FORT WAVNE & 46803 & 4104466 & 8506158 & CHERM GRONIN & $(219), 427,1243$ & 205,727 & 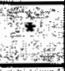 & 60 & 70 & 6 & ALLEN \\
\hline $\begin{array}{l}\text { FORTVI } \\
\text { MUNICIPA K WWTP }\end{array}$ & $\begin{array}{l}\text { TOWNOF } \\
\text { EORNVLLESTE }\end{array}$ & $\begin{array}{l}714 \text { EAST } \\
\text { BROADWAY }\end{array}$ & (1) & FORTVLEE, & 46046 & 3956006 & 855417 & $\begin{array}{l}\text { MR ROBERT } \\
\text { ANE EERT OP } \\
\text { G }\end{array}$ & $(317), 485-5432$ & 3,444 & 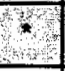 & 07 & 50 & 10 & HANCOCK \\
\hline $\begin{array}{l}\text { FOUNTAIN CITY } \\
\text { MUNICIPAL WWTP }\end{array}$ & $\begin{array}{l}\text { FOUNTAIN CITY } \\
\text { MUNICIPAL WWTP }\end{array}$ & P.O. BOX 312 & & FOUNTAIN CITY & 47341 & 3957200 & -8455200 & $\begin{array}{l}\text { MR. BOBBY } \\
\text { SHAFFER }\end{array}$ & (765) 847-2251 & 735 & & 0.108 & 100 & & WAYNE \\
\hline FOWLER WWTP & $\begin{array}{l}\text { FOWLER } \\
\text { MUNICIPAL STP }\end{array}$ & 307 E. 5TH ST. & & FOWLER & 47944 & 4036317 & -8719133 & MR. ALAN LEUCK & (765) 884-0680 & 2,415 & & 0.75 & 100 & & BENTON \\
\hline $\begin{array}{l}\text { FRANCESVILLE } \\
\text { MUNICIPAL WWTP }\end{array}$ & $\begin{array}{l}\text { FRANCESVILLE } \\
\text { MUNICIPAL STP }\end{array}$ & P.O. BOX 616 & & FRANCESVILLE & 47946 & 4059100 & -8652500 & $\begin{array}{l}\text { MR. DOUG } \\
\text { GUTWEIN }\end{array}$ & (219) 567-9521 & 905 & & 0.12 & & & PULASKI \\
\hline RRANKFORT WWMP & $\begin{array}{l}\text { ERANKFORT } \\
\text { MENICIPAL WWIP }\end{array}$ & $16 \mathrm{~N}$ MAIN ST, & & HRANKFORT & 46041 & 4017557 & 8630245 & $\begin{array}{l}\text { MR DENNIS } \\
\text { SHIRAR }\end{array}$ & $(765) 6594741$ & 16,662 & + & 4.68 & 20 & 20 & Cunion \\
\hline FRANMLN WWMT & FRANKLIIN & $\begin{array}{l}796 \text { SOUTH } \\
\text { STATE STKEET }\end{array}$ & & FRANKLIN: & $46 t 31$ & 3928062 & 8602265 & $\begin{array}{l}\text { MR RACK } \\
\text { HTERON }\end{array}$ & (317) $736-3640$ & 19463 & & 4 & 80 & & 1OHNon \\
\hline $\begin{array}{l}\text { FRANKTON } \\
\text { MUNICIPAL WWTP }\end{array}$ & $\begin{array}{l}\text { FRANKTON } \\
\text { MUNICIPAL STP }\end{array}$ & P.O. BOX 286 & $\begin{array}{l}105 \text { CHURCH } \\
\text { STREET }\end{array}$ & FRANKTON & 46044 & 4013332 & -8546584 & $\begin{array}{l}\text { MR. JERRY } \\
\text { HEATH }\end{array}$ & (317) 754-7013 & 1,905 & & 0.286 & 100 & & MADISON \\
\hline FREMONT WWTP & $\begin{array}{l}\text { FREMONT } \\
\text { MUNICIPAL STP }\end{array}$ & P.O. BOX 602 & $\begin{array}{l}205 \mathrm{~N} . \\
\text { TOLFORD }\end{array}$ & FREMONT & 46737 & 4143500 & -8455500 & \begin{tabular}{|l} 
JAMES \\
HUMBARGER, \\
CERT. OPER.
\end{tabular} & (219) 495-9933 & 1,696 & & 0.3 & 100 & & STEUBEN \\
\hline $\begin{array}{l}\text { FRENCH LICK } \\
\text { MUNICIPAL WWTP }\end{array}$ & $\begin{array}{l}\text { TOWN OF FRENCH } \\
\text { LICK STP }\end{array}$ & P. O. BOX 10 & & FRENCH LICK & 47432 & 3834243 & -8636572 & $\begin{array}{l}\text { MR. TONY } \\
\text { WILLOUGHBY }\end{array}$ & (812) 936-4513 & 1,941 & & 0.7 & 30 & 10 & ORANGE \\
\hline FULTON WWTP & FULTON WWTP & $\begin{array}{l}\text { TOWN COUNCIL } \\
\text { OF FULTON }\end{array}$ & P.O. BOX 155 & FULTON & 46931 & 4057424 & -8615528 & $\begin{array}{l}\text { MR. ELWYNE. } \\
\text { BECKER } \\
\end{array}$ & & 326 & & .033 & & & FULTON \\
\hline $\begin{array}{l}\text { GALVESTON } \\
\text { MUNICIPAL WWTP }\end{array}$ & $\begin{array}{l}\text { GALVESTON } \\
\text { MUNICIPAL WWIP }\end{array}$ & P.O. BOX 597 & $\begin{array}{l}\text { 302 E. } \\
\text { JACKSON ST }\end{array}$ & GALVESTON & 46932 & 4034480 & -8611060 & $\begin{array}{l}\text { MR. JOHN } \\
\text { ROBERSON }\end{array}$ & (219) 699-6440 & 1,532 & & 0.418 & 100 & & CASS \\
\hline GARRETT WWTP & GARRETT WWTP & P. O. BOX 120 & & GARRETT & 46738 & 4120289 & -8507465 & $\begin{array}{l}\text { MR. JEFF } \\
\text { BARTELS } \\
\end{array}$ & (219) 357-5449 & 5,803 & & 0.8 & 100 & & DE KALB \\
\hline
\end{tabular}


Directory of Indiana POTWs Compiled from EPAIDEM Files

Compilation Date: May, 2001

Indiana Clean Manufacturing Technology and Safe Materials Institute

Purdue University

West Lafayette, Indiana

(Updated 1/13/04)

\begin{tabular}{|c|c|c|c|c|c|c|c|c|c|c|c|c|c|c|c|}
\hline Facility Name & Mailing Name & Mailing Street 1 & Mailing Street 2 & Mailing City & $\frac{\text { ZIP }}{\text { Code }}$ & Latitude & Longitude & $\begin{array}{l}\text { Official } \\
\text { Representative }\end{array}$ & $\begin{array}{l}\text { Official } \\
\text { Representative } \\
\text { Telephone } \\
\text { Number } \\
\end{array}$ & $\frac{P o p}{(2000)}$ & $\underline{\mathrm{CS}}$ & Q Design & $\underline{\frac{\%}{\text { San }}}$ & $\%$ ind & County \\
\hline $\begin{array}{l}\text { GARY SANITARY } \\
\text { DISTRICT }\end{array}$ & GARYWWTP & 401 BROADWAY & & GARY & $\begin{array}{l}404 \\
46402 \\
\end{array}$ & 44136235 & $\begin{array}{l}\text { X } \\
6723027 \\
\end{array}$ & $\begin{array}{l}\text { CHARLES } \\
\text { PEVIER, GSDB } \\
\text { ERECTOR }\end{array}$ & (219) 944 0595 & 102,746 & 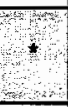 & 60 & 98 & 20 & LAKE \\
\hline \begin{tabular}{|l|} 
GAS CITY WATER \\
POLLUTION CONTR
\end{tabular} & GAS CITY WWTP & $\begin{array}{l}500 \text { SOUTH } \\
\text { BROADWAY }\end{array}$ & & GAS CITY & 46933 & 4029008 & -8537172 & $\begin{array}{l}\text { MR. JIM } \\
\text { RICHARDS }\end{array}$ & (317) 677-3083 & 5,940 & & 2 & 100 & 4 & GRANT \\
\hline $\begin{array}{l}\text { GASTON } \\
\text { MUNICIPAL } \text { WWTP }\end{array}$ & $\begin{array}{l}\text { GASTON MUNICIPAL } \\
\text { STP }\end{array}$ & P.O. BOX 186 & $\begin{array}{l}107 \mathrm{~N} . \\
\text { SYCAMORE }\end{array}$ & GASTON & 47342 & 4019009 & -8530191 & $\begin{array}{l}\text { MR. RAY } \\
\text { GILLESPIE }\end{array}$ & (765) 358-3244 & 1,010 & & 0.2 & 100 & & DELAWARE \\
\hline $\begin{array}{l}\text { GENEVA } \\
\text { MUNICIPAL WWTP }\end{array}$ & $\begin{array}{l}\text { GENEVA MUNICIPAL } \\
\text { WWTP }\end{array}$ & P. O. BOX 276 & $\begin{array}{l}200 \text { LINE } \\
\text { STREET }\end{array}$ & GENEVA & 46740 & 4035312 & -8456518 & MR. JIM TIMMONS & (219) 368-9179 & 1,368 & & 0.3 & & & ADAMS \\
\hline $\begin{array}{l}\text { GENTRYVILLE } \\
\text { WWTP }\end{array}$ & $\begin{array}{l}\text { GENTRYVILLE } \\
\text { WWTP }\end{array}$ & \begin{tabular}{|l|} 
MS. MARTHA \\
DEWITT, PRES.
\end{tabular} & P.O. BOX 161 & GENTRYVILLE & 47537 & 3805573 & -8704025 & $\begin{array}{l}\text { MS. MARTHA } \\
\text { DEWITT }\end{array}$ & & 262 & & 0.063 & & & SPENCER \\
\hline $\begin{array}{l}\text { GOODLAND } \\
\text { MUNICIPAL WWTP }\end{array}$ & $\begin{array}{l}\text { GOODLAND } \\
\text { MUNICIPAL WWTP }\end{array}$ & P. O. BOX 269 & & GOODLAND & 47948 & 4047362 & -8717536 & MR. JOHN MILLER & (219) 297-3693 & 1,096 & & 0.135 & & & NEWTON \\
\hline GOSHEN WWIP & GOSHENGTHGTIES & P.O BOX 238 & 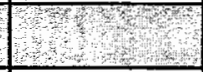 & GOSHEN : & 46526 & 435478 & 855114 & $\begin{array}{l}\text { MR DOUGEASD } \\
\text { PERRY, GERT OP }\end{array}$ & $(219), 534-5701$ & 29,383 & the & 5 & 45 & 9 & ELKHART \\
\hline $\begin{array}{l}\text { GOSPORT } \\
\text { MUNICIPAL STP }\end{array}$ & $\begin{array}{l}\text { GOSPORT } \\
\text { MUNICIPAL WWTP }\end{array}$ & P.O. BOX 146 & $\begin{array}{l}4 \text { SOUTH THIRD } \\
\text { STREET }\end{array}$ & GOSPORT & 47433 & 3920417 & -8639398 & $\begin{array}{l}\text { MR. JEFF S. } \\
\text { FARMER }\end{array}$ & $(812) 332-8030$ & 715 & & 0.061 & 100 & & OWEN \\
\hline $\begin{array}{l}\text { GRANDVIEW } \\
\text { MUNICIPAL WWTP }\end{array}$ & $\begin{array}{l}\text { GRANDVIEW } \\
\text { MUNICIPAL WWTP }\end{array}$ & $\begin{array}{l}\text { GRANDVIEW } \\
\text { TOWN HALL }\end{array}$ & P.O. BOX 638 & GRANDVIEW & 47615 & 3756353 & -8700185 & $\begin{array}{l}\text { MR. BILL KEITH, } \\
\text { TOWN MANAGER }\end{array}$ & (812) 649-2573 & 696 & & 0.12 & & & SPENCER \\
\hline GREENAASTLE & $\begin{array}{l}\text { GREENCASTLEE } \\
\text { MUNICIPAL STT }\end{array}$ & WEST & & GREENGAS & 46135 & 39346 & 1865240 & $\begin{array}{l}\text { MS GHARLENE } \\
\text { NGHOLS }\end{array}$ & (765) 653 3994 & 9,800 & & 18 & 100 & 20 & Puinau \\
\hline GREENDALE WWTP & $\begin{array}{l}\text { TOWN OF } \\
\text { GREENDALE }\end{array}$ & \begin{tabular}{|l|} 
CONNECTED TO \\
SOUTH \\
DEARBORN \\
\end{tabular} & RSD & GREENDALE & 47025 & 391597 & -848764 & RAY HALLER & (812) 537-0457 & 4,296 & & & & & DEARBORN \\
\hline $\begin{array}{l}\text { GREENFIELD } \\
\text { WWTP }\end{array}$ & $\begin{array}{l}\text { GREENFIELD } \\
\text { MUNIGIPALSTE }\end{array}$ & 809 S STATE ST & $\mathrm{PO} \mathrm{OBO} \times 456$ & GREENAIELB & 46140 & 394638 & 8545467 & $\begin{array}{l}\text { MR DAVID } \\
\text { SCHEITER }\end{array}$ & $(317) 462-8530$ & 14,600 & 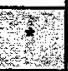 & 32 & 80 & 30 & HANCOCK \\
\hline $\begin{array}{l}\text { GREENSBURG } \\
\text { WWTP }\end{array}$ & $\begin{array}{l}\text { GREENSBURG } \\
\text { MUNIGIPAL WWIP }\end{array}$ & $\begin{array}{l}\text { GITYHAL } 314 \\
\text { N MiGHGAN }\end{array}$ & W/2 & GREENSBQURG & 47240 & 3919380 & 8529080 & $\begin{array}{l}\text { MR JEFFREYH } \\
\text { SMITH }\end{array}$ & $(812) 663.2138$ & 10,260 & 1 & 1.6 & 70 & 10 & DECATUR \\
\hline $\begin{array}{l}\text { GREENTOWN } \\
\text { MUNICIPAL WWTP }\end{array}$ & $\begin{array}{l}\text { GREENTOWN } \\
\text { WWTP }\end{array}$ & $\begin{array}{l}\text { TOWN OF } \\
\text { GREENTOWN }\end{array}$ & $\begin{array}{l}112 \mathrm{~N} . \\
\text { MERIDIAN ST }\end{array}$ & GREENTOWN & 46936 & 4028420 & -8557480 & MR. BILL ROSS & (765) 628-3447 & 2,546 & & 0.18 & 100 & 5 & HOWARD \\
\hline $\begin{array}{l}\text { GREENWOOD } \\
\text { SANTATONOTET }\end{array}$ & $\begin{array}{l}\text { GREENWOOO } \\
\text { SANTATONOUT }\end{array}$ & $367 \mathrm{~S}$ WASHON & & QRELNWOOD & 46143 & 3936349 & 8606072 & MR KLTH MEERR & $(31) 1) 880-1254$ & 360 & & 15 & & & OHNSON \\
\hline $\begin{array}{l}\text { HAGERSTOWN } \\
\text { MUNICIPAL WWTP }\end{array}$ & $\begin{array}{l}\text { HAGERSTOWN } \\
\text { MUNICIPAL STP }\end{array}$ & $\begin{array}{l}49 \text { EAST MAIN } \\
\text { STREET }\end{array}$ & & HAGERSTOWN & 47346 & 3954132 & -8509404 & $\begin{array}{l}\text { MR. GREGORY } \\
\text { OZBUN, CERT. } \\
\text { OPER. }\end{array}$ & (765) 489-6171 & 1,768 & & 0.75 & 100 & & WAYNE \\
\hline $\begin{array}{l}\text { HAMILTON LAKE } \\
\text { CONSER. DIST } \\
\end{array}$ & $\begin{array}{l}\text { HAMILTON LAKE } \\
\text { CONSER. DIST } \\
\end{array}$ & P. O. BOX 331 & & HAMILTON & 46742 & 4131597 & -8453478 & $\begin{array}{l}\text { MR. PETER J. } \\
\text { CROWL, } \\
\text { SUPERINT. } \\
\end{array}$ & (219) 488-3251 & 1,233 & & 0.3 & 100 & & STEUBEN \\
\hline $\begin{array}{l}\text { HAMLET MUNICIPAL } \\
\text { WWTP }\end{array}$ & $\begin{array}{l}\text { HAMLET MUNICIPAL } \\
\text { STP }\end{array}$ & $\begin{array}{l}10 \text { SOUTH } \\
\text { STARKE ST }\end{array}$ & & HAMLET & 46532 & 4122157 & -8635304 & $\begin{array}{l}\text { MR. CURTIS } \\
\text { SIMPKINS, PRES. }\end{array}$ & (219) 867-1755 & 820 & & 0.1 & 100 & & STARKE \\
\hline HAMMOND WWTP & HAMMONO WWTP & 5143 COLUMBIA & & HANIMONB & 46327 & 4137110 & 8729440 & $\begin{array}{l}\text { BR MIGHAEL } \\
\text { UNGER }\end{array}$ & $(219) 853-6413$ & 83,048 & & 378 & 35 & 10 & LAKE: \\
\hline HANOVER WWTP & $\begin{array}{l}\text { HANOVER } \\
\text { MUNICIPAL STP }\end{array}$ & P. O. BOX 288 & $\begin{array}{l}11 \text { MADISON } \\
\text { AVE. }\end{array}$ & HANOVER & 47243 & 3842384 & -8527278 & $\begin{array}{l}\text { MR. JOSEPH } \\
\text { HOLTGREWE }\end{array}$ & $(812) 866-2131$ & 2,834 & & 0.54 & 100 & & JEFFERSON \\
\hline
\end{tabular}


Directory of Indiana POTWS Compiled from EPAIDEM Files

Compilation Date: May, 2001

Indiana Clean Manufacturing Technology and Safe Materials Institute

Purdue University

West Lafayette, Indiana

(Updated 1/13/04)

\begin{tabular}{|c|c|c|c|c|c|c|c|c|c|c|c|c|c|c|c|}
\hline Facilify Name & Mailing Name & Mailing Street 1 & Mailing Street 2 & Mailing City & $\frac{\text { ZIP }}{\text { Code }}$ & Latitude & Longitude & $\begin{array}{l}\text { Official } \\
\text { Representative }\end{array}$ & $\begin{array}{l}\text { Official } \\
\text { Representalive } \\
\text { Telephone } \\
\text { Number } \\
\end{array}$ & $\frac{P o p}{(2000)}$ & $\underline{\mathrm{CS}}$ & QDesign & $\underline{\underline{\%}}$ & $\%$ Ind & County \\
\hline $\begin{array}{l}\text { HARTFORD CITY } \\
\text { WWTP }\end{array}$ & $\begin{array}{l}\text { HARTFORD CITY } \\
\text { WWTP }\end{array}$ & 700 N. WALNUT & & HARTFORD CITY & 47348 & 4026077 & -8523078 & $\begin{array}{l}\text { MR. WAYNE } \\
\text { RITENOUR }\end{array}$ & (765) 348-3855 & 6,928 & * & 2.2 & 15 & 20 & BLACKFORD \\
\hline HARTSVILLE WWTP & \begin{tabular}{|l} 
TOWN OF \\
HARTSVILLE STP
\end{tabular} & P. O. BOX 812 & & HARTSVILLE & 47244 & 3916273 & -8541476 & $\begin{array}{l}\text { MR. CHUCK } \\
\text { LUURTSEMA, } \\
\text { PRES. }\end{array}$ & (812) 546-5658 & 376 & & 0.078 & 100 & & BARTHOLOMEW \\
\hline $\begin{array}{l}\text { HAUBSTADT } \\
\text { MUNICIPAL WWTP }\end{array}$ & $\begin{array}{l}\text { HAUBSTADT } \\
\text { MUNICIPAL WWTP }\end{array}$ & P.O. BOX 365 & $\begin{array}{l}101 \text { SOUTH } \\
\text { MAIN ST. }\end{array}$ & HAUBSTADT & 47639 & 3812335 & -8734083 & $\begin{array}{l}\text { MR. BRYONS. } \\
\text { WILL }\end{array}$ & (812) 768-5929 & 1,529 & & 0.3 & 100 & & GIBSON \\
\hline $\begin{array}{l}\text { HEBRON } \\
\text { MUNICIPAL WWTP }\end{array}$ & $\begin{array}{l}\text { HEBRON } \\
\text { MUNICIPAL STP }\end{array}$ & P.O. BOX 478 & $\begin{array}{l}106 \text { EAST } \\
\text { SIGLER }\end{array}$ & HEBRON & 46341 & 4118553 & -8711176 & $\begin{array}{l}\text { MR. STEVE } \\
\text { MARTIN }\end{array}$ & (219) 996-3021 & 3,596 & & 0.52 & 100 & & PORTER \\
\hline $\begin{array}{l}\text { HENDRICKS } \\
\text { COUNTY RSD }\end{array}$ & $\begin{array}{l}\text { HENDRICKS } \\
\text { COUNTY RSD }\end{array}$ & P.O. BOX 310 & & DANVILLE & 46122 & 3945385 & -8619564 & $\begin{array}{l}\text { MS. CATHY } \\
\text { GRINDSTAFF }\end{array}$ & $(317) 745-9217$ & - & & 0.31 & & & HENDRICKS \\
\hline HENRYVILLE WWTP & $\begin{array}{l}\text { HENRYVILLE } \\
\text { MEMBERSHIP }\end{array}$ & $\begin{array}{l}\text { SANITATION } \\
\text { CORPORATION }\end{array}$ & P.O. BOX 62 & HENRWILLE & 47126 & 3830483 & -8545572 & $\begin{array}{l}\text { MR. DENNIS } \\
\text { REAFSNIDER }\end{array}$ & $(812) 294-1070$ & 1,545 & & 0.2374 & 100 & & CLARK \\
\hline \begin{tabular}{|l|} 
HILLSBORO \\
MUNICIPAL STP
\end{tabular} & $\begin{array}{l}\text { TOWN COUNCIL OF } \\
\text { HILLSBORO }\end{array}$ & $\begin{array}{l}\text { HILLSBORO } \\
\text { MUNICIPAL STP }\end{array}$ & $\begin{array}{l}2064 \text { EAST U.S. } \\
136\end{array}$ & HILLSBORO & 47949 & 4006200 & -8709400 & $\begin{array}{l}\text { MR. PHILIP } \\
\text { DOTSON }\end{array}$ & (765) 798-5055 & 489 & & 0.065 & & & FOUNTAIN \\
\hline HOLLAND WWTP & $\begin{array}{l}\text { HOLLAND } \\
\text { MUNICIPAL WWTP }\end{array}$ & $\begin{array}{l}8825 \text { COUNTY } \\
\text { ROAD } 750 \mathrm{~W} \text {. }\end{array}$ & & HOLLAND & 47541 & 3814521 & -8703071 & $\begin{array}{l}\text { MR. JERRY } \\
\text { TISLOW }\end{array}$ & (812) 536-3641 & 695 & & 0.1 & 100 & & DUBOIS \\
\hline $\begin{array}{l}\text { HOLTON } \\
\text { MUNICIPAL WWTP }\end{array}$ & $\begin{array}{l}\text { HOLTON MUNICIPAL } \\
\text { WWTP }\end{array}$ & P.O. BOX 156 & TOWN HALL & HOLTON & 47023 & 3904479 & -8524137 & $\begin{array}{l}\text { MRS. PEGGY } \\
\text { FURST }\end{array}$ & (812) 689-3269 & 407 & & 0.078 & & & RIPLEY \\
\hline HOPE WWTP & $\begin{array}{l}\text { TOWN OF HOPE } \\
\text { STP }\end{array}$ & $\begin{array}{l}404 \text { JACKSON } \\
\text { ST. }\end{array}$ & & HOPE & 47246 & 3917365 & -8546541 & JAY POWER & (812) 546-5469 & 2,140 & & 0.316 & 100 & & BARTHOLOMEW \\
\hline $\begin{array}{l}\text { HUNTINGBURG } \\
\text { MUNICIPAL WWTP }\end{array}$ & $\begin{array}{l}\text { HUNTINGBURG } \\
\text { MUNICIPAL WWTP }\end{array}$ & $\begin{array}{l}508 \text { EAST } \\
\text { FOURTH ST } \\
\end{array}$ & & HUNTINGBURG & 47542 & 3817359 & -8656315 & MR. RON HALL & (812) 683-3203 & 5,598 & & 1 & 100 & 1 & DUBOIS \\
\hline $\begin{array}{l}\text { HUNTINGTON } \\
\text { WATER POLE, }\end{array}$ & $\begin{array}{l}\text { HUNTINGTON } \\
\text { MUNIEIPALSTP }\end{array}$ & $\mathrm{CIYBEDG}$ & $\begin{array}{l}300 \text { CHERRY } \\
\text { STREET }\end{array}$ & HUNTNGTON & 46750 & 4052246 & 8530511 & $\begin{array}{l}\text { COWNE } \\
\text { BulloGK }\end{array}$ & $(219) 358-2313$ & 17,450 & 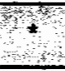 & 4.6 & 15 & 17 & HUNIINGION \\
\hline $\begin{array}{l}\text { HYMERA SEWAGE } \\
\text { PLANT }\end{array}$ & $\begin{array}{l}\text { HYMERA } \\
\text { MUNICIPAL STP }\end{array}$ & P.O. BOX 421 & & HYMERA & 47855 & 3911000 & -8719000 & MR. JIM MARKET & (812) 383-7333 & 833 & & 0.25 & 100 & & SULLIVAN \\
\hline $\begin{array}{l}\text { INDPLS. DEPT. OF } \\
\text { PUBLIC WORKS }\end{array}$ & $\begin{array}{l}\text { INDPLS. DEPT. OF } \\
\text { PUBLIC WORKS }\end{array}$ & $\begin{array}{l}\text { BELMONT } \\
\text { WWTP } \\
\end{array}$ & $\begin{array}{l}2700 \mathrm{~S} \\
\text { BELMONT }\end{array}$ & INDIANAPOLIS & 46221 & 3939599 & -8613429 & $\begin{array}{l}\text { MR. GEORGE } \\
\text { RUSSELL }\end{array}$ & (317) $327-2455$ & 786,898 & $\star$ & 120 & 65 & 28 & MARION \\
\hline $\begin{array}{l}\text { INDPLS. DEPT. OF } \\
\text { PUBLIC WORKS }\end{array}$ & $\begin{array}{l}\text { INDPLS. DEPT. OF } \\
\text { PUBLIC WORKS }\end{array}$ & $\begin{array}{l}\text { SOUTHPORT } \\
\text { WWTP } \\
\end{array}$ & $\begin{array}{l}2700 \text { S. } \\
\text { BELMONT AVE. }\end{array}$ & INDIANAPOLIS & 46221 & 3939599 & -8613429 & $\begin{array}{l}\text { MR. GEORGE } \\
\text { RUSSELL }\end{array}$ & (317) 327-0200 & 786,898 & * & 125 & 65 & 28 & MARION \\
\hline JACKSON COUNTY & $\begin{array}{l}\text { JACKSON CO REG } \\
\text { SEWAGE DIST }\end{array}$ & $\begin{array}{l}4241 \text { COUNTY } \\
\text { ROAD } 675 \mathrm{~N}\end{array}$ & & FREETOWN & 47235 & 3858245 & -8607099 & $\begin{array}{l}\text { MR. DAN } \\
\text { ROBERTSON }\end{array}$ & (812) 497-3072 & - & & 0.09 & 100 & & JACKSON \\
\hline $\begin{array}{l}\text { JAMES B GIFFORD } \\
\text { WWTP }\end{array}$ & $\begin{array}{l}\text { MICHIGAN CITY } \\
\text { SANITARY DISTR }\end{array}$ & $\begin{array}{l}100 \text { E EIGHTH } \\
\text { STREET }\end{array}$ & BOX 888 & MIGHIGAN CITY & 46360 & 4143060 & 8652540 & 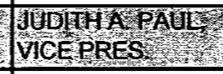 & $(219) 874-7799$ & 32,900 & t & 12 & 40 & 10 & LAPORTE \\
\hline \begin{tabular}{|l|} 
JAMESTOWN \\
MUNICIPAL WWTP
\end{tabular} & $\begin{array}{l}\text { JAMESTOWN } \\
\text { MUNICIPAL WWTP }\end{array}$ & $\begin{array}{l}606 \text { LOWRY } \\
\text { STREET }\end{array}$ & & JAMESTOWN & 46147 & 3955212 & -8637268 & $\begin{array}{l}\text { MR. RICHARD A. } \\
\text { BEAM, PRES. }\end{array}$ & (765) 676-6331 & 886 & & 0.1 & 100 & & BOONE \\
\hline $\begin{array}{l}\text { JASONVILLE } \\
\text { MUNICIPAL WWTP }\end{array}$ & $\begin{array}{l}\text { JASONVILLE MUN. } \\
\text { STP }\end{array}$ & 304 WEST MAIN & CITY HALL & JASONVILLE & 47438 & 3909082 & -8711181 & $\begin{array}{l}\text { MR. JAMES F. } \\
\text { MARKET }\end{array}$ & & 2,490 & & 0.46 & 100 & & GREENE \\
\hline JASPER WWMT & JASPER MUNACIPAC & $0 . B O \times \quad 150$ & & JASPER & 47547 & 3823065 & 8656246 & $\begin{array}{l}\text { MR THOMAS } \\
\text { ENTS }\end{array}$ & $(812) 482-3277$ & $\because 2,00$ & & 36 : & 98 & 20 & DuBOis \\
\hline $\begin{array}{l}\text { JEFFERSON } \\
\text { TOWNSHIP RSD }\end{array}$ & $\begin{array}{l}\text { JEFFERSON } \\
\text { TOWNSHIP RSD }\end{array}$ & P.O. BOX 86 & & OTWELL & 47564 & 3827428 & -8704591 & MR. GARY PRIDE & $(812) 354-2256$ & - & & 0.075 & 100 & & PIKE \\
\hline
\end{tabular}


Compilation Date: May, 2001

Indiana Clean Manufacturing Technology and Safe Materials Institute

Purdue University

West Lafayette, Indiana

(Updated 1/13/04)

\begin{tabular}{|c|c|c|c|c|c|c|c|c|c|c|c|c|c|c|c|}
\hline Facility Name & Malling Name & Mailing Street 1 & Mailing Street 2 & Malling City & ZIP & Latitude & Longitude & $\begin{array}{l}\text { Official } \\
\text { Representative }\end{array}$ & 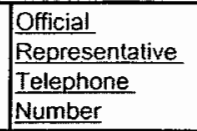 & $\frac{\text { Pop }}{(2000)}$ & $\underline{\mathrm{CS}}$ & Q Design & $\underline{\%}$ & $\%$ Ind & County \\
\hline $\begin{array}{l}\text { JEFFERSONVILLE } \\
\text { WWTP }\end{array}$ & $\begin{array}{l}\text { JEFFERSONVILLE } \\
\text { MUNICIPAL WWIP }\end{array}$ & $\begin{array}{l}\text { CTIY COUNTY, } \\
\text { BDG,RM } 400\end{array}$ & $\begin{array}{l}\text { 501 EAST } \\
\text { COURT AVE }\end{array}$ & JEFFERSONVILLE & 47131 & 3817102 & 8544385 & CRAWFORD & (812) 285-6451 & 27,362 & Fis & 4 & 44 & & CLARK \\
\hline $\begin{array}{l}\text { KENDALLVILLE } \\
\text { WWTP }\end{array}$ & $\begin{array}{l}\text { KENDALLVILEE } \\
\text { WWTP }\end{array}$ & $\begin{array}{l}501 \text { WEST MAIN } \\
\text { ST, }\end{array}$ & (2) & KENDALLVLLE & 46755 & 4126450 & 8 & $\begin{array}{l}\text { MRERIGHARD } \\
\text { MGGEE, SUPT }\end{array}$ & (219) 347-1362. & 9,616 & t & 2.68 & 95 & & NOBLE \\
\hline \begin{tabular}{|l|} 
KENNARD \\
MUNICIPAL WWTP
\end{tabular} & $\begin{array}{l}\text { KENNARD } \\
\text { MUNICIPAL STP }\end{array}$ & P.O. BOX 114 & & KENNARD & 47351 & 3953463 & -8530536 & $\begin{array}{l}\text { MR. CHARLES } \\
\text { MILLIS }\end{array}$ & (765) 785-2554 & 455 & & 0.08 & 100 & & HENRY \\
\hline \begin{tabular}{|l|} 
KENTLAND \\
MUNICIPAL WWTP \\
\end{tabular} & $\begin{array}{l}\text { KENTLAND } \\
\text { MUNICIPAL WWTP }\end{array}$ & P.O. BOX 218 & & KENTLAND & 47951 & 4047031 & -8726561 & $\begin{array}{l}\text { MR. TERRY D. } \\
\text { HAFSTROM }\end{array}$ & (219) 474-3233 & 182 & & 0.46 & 100 & & NEWTON \\
\hline $\begin{array}{l}\text { KINGMAN } \\
\text { MUNICIPAL WWTP } \\
\end{array}$ & $\begin{array}{l}\text { TOWN OF KINGMAN } \\
\text { STP }\end{array}$ & P.O. BOX 25 & STATE STREET & KINGMAN & 47952 & 3959000 & -8718000 & $\begin{array}{l}\text { MR. JOHN } \\
\text { MCBRIDE }\end{array}$ & (217) 267-2331 & 538 & & 0.07 & & & FOUNTAIN \\
\hline $\begin{array}{l}\text { KINGSBURY } \\
\text { UTILITY CORP } \\
\end{array}$ & $\begin{array}{l}\text { KINGSBURY UTILITY } \\
\text { CORP. }\end{array}$ & P. O. BOX 254 & & KINGSBURY & 46345 & 4129432 & -8640089 & $\begin{array}{l}\text { MR.JEFF } \\
\text { JOHNSON }\end{array}$ & (219) 393-3577 & 229 & & 2.5 & 100 & & LAPORTE \\
\hline $\begin{array}{l}\text { KINGSFORD } \\
\text { HEIGHTS WWTP } \\
\end{array}$ & \begin{tabular}{|l} 
KINGSFORD \\
HEIGHTS MUNI \\
WWTP
\end{tabular} & $\begin{array}{l}\text { 504 GRAYTON } \\
\text { ROAD }\end{array}$ & & $\begin{array}{l}\text { KINGSFORD } \\
\text { HEIGHTS }\end{array}$ & 46346 & 4128142 & -8641216 & MR. TIM VANCE & (219) 393-3304 & 1,453 & & 0.422 & 100 & & LAPORTE \\
\hline $\begin{array}{l}\text { KIRKLIN MUNICIPAL } \\
\text { WWTP }\end{array}$ & $\begin{array}{l}\text { KIRKLIN MUNICIPAL } \\
\text { WWTP } \\
\end{array}$ & P. О. BOX 147 & $\begin{array}{l}\text { 802 NORTH } \\
\text { MAIN STREET }\end{array}$ & KIRKLIN & 46050 & 4011585 & -8621581 & $\begin{array}{l}\text { MR. WILEER D. } \\
\text { BOWMAN }\end{array}$ & (765) 279-5251 & 766 & & 0.14 & 100 & & CLINTON \\
\hline $\begin{array}{l}\text { KNIGHTSTOWN } \\
\text { WWTP } \\
\end{array}$ & $\begin{array}{l}\text { KNIGHTSTOWN } \\
\text { MUNICIPAL STP }\end{array}$ & $\begin{array}{l}26 \text { SOUTH } \\
\text { WASHINGTON }\end{array}$ & P. O. BOX 270 & KNIGHTSTOWN & 46148 & 3947117 & -8531323 & $\begin{array}{l}\text { MR. MEL } \\
\text { MATLOCK, TOWN } \\
\text { WORKS MGR. }\end{array}$ & (765) 345-5804 & 2,148 & & 0.31 & 100 & & HENRY \\
\hline $\begin{array}{l}\text { KNOX MUNICIPAL } \\
\text { WWTP }\end{array}$ & CITY OF KNOX STP & $\begin{array}{l}101 \mathrm{~W} . \\
\text { WASHINGTON }\end{array}$ & & KNOX & 46534 & 4118211 & -8637420 & $\begin{array}{l}\text { NANCY } \\
\text { DEMBOWSKI. } \\
\text { MAYOR }\end{array}$ & (219) $772-2961$ & 3,721 & $\star$ & 0.51 & 80 & & STARKE \\
\hline KOKOMO WWTP & $\begin{array}{l}\text { KOKOMO } \\
\text { MUUNICIPAL STP }\end{array}$ & $\begin{array}{l}1 \text { 100 SEONION } \\
\text { ST: }\end{array}$ & 7. & KOKOMO & 46901 & 4028340 & 8609044 & $\begin{array}{l}\text { MRE GREGGRYA } \\
\text { TAMLOR }\end{array}$ & $(765): 457-5509$ & 46,113 & 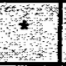 & 30 & 60 & 35 & HOWARD \\
\hline \begin{tabular}{l|} 
KOUTS MUNICIPAL \\
WWTP \\
\end{tabular} & $\begin{array}{l}\text { KOUTS MUNICIPAL } \\
\text { WWTP }\end{array}$ & TOWN HALL & P.O. BOX 693 & KOUTS & 46347 & 4118396 & -8702139 & $\begin{array}{l}\text { MR. BARRY } \\
\text { LOBODY }\end{array}$ & (219) $766-2110$ & 1,698 & & 0.25 & 100 & 5 & PORTER \\
\hline \begin{tabular}{|l|} 
LACROSSE \\
MUNICIPAL WWTP
\end{tabular} & \begin{tabular}{|l|} 
LACROSSE \\
MUNICIPAL WWTP \\
\end{tabular} & TOWN HALL & P.O. BOX 246 & LACROSSE & 46348 & 4119000 & -8653300 & $\begin{array}{l}\text { MR. DENNIS } \\
\text { TURNER } \\
\end{array}$ & (219) $754-2512$ & 561 & & 0.067 & & & LAPORTE \\
\hline $\begin{array}{l}\text { LADOGA } \\
\text { MUNICIPAL WWTP }\end{array}$ & $\begin{array}{l}\text { TOWN OF LADOGA } \\
\text { STP }\end{array}$ & P. O. BOX 187 & 121 E. MAIN ST. & LADOGA & 47954 & 3954300 & -8648000 & $\begin{array}{l}\text { MR. DARIN } \\
\text { GARRET, CERT. } \\
\text { OPER. }\end{array}$ & (317) 942-2531 & 1,047 & & 0.25 & 100 & & MONTGOMERY \\
\hline GAFAYETTE WWTP & $\begin{array}{l}\text { LAFAYETEE WUICIPAL WWTP } \\
\text { MUN }\end{array}$ & B. B. BOX 1688 & Py & LAFAYETIE & 47902 & 4024043 & 86541,07) & MARRADWE & $(765) 742.1424$ & 56,397 & $x$ & 16. & 0.5 & 45 & TIPPECANOE \\
\hline $\begin{array}{l}\text { LAFONTAINE } \\
\text { MUNICIPAL WWTP } \\
\end{array}$ & $\begin{array}{l}\text { TOWN OF } \\
\text { LAFONTAINE STP }\end{array}$ & P. O. BOX 207 & & LAFONTAINE & 46940 & 4040266 & -8543529 & $\begin{array}{l}\text { MR. OENNIS L. } \\
\text { JONES }\end{array}$ & (765) 981-4591 & 900 & & 0.1 & 100 & & WABASH \\
\hline \begin{tabular}{|l|} 
LAGRANGE \\
MUNICIPAL WWTP
\end{tabular} & \begin{tabular}{|l|} 
LAGRANGE \\
MUNICIPAL WWTP
\end{tabular} & \begin{tabular}{|l|}
107 SOUTH \\
HIGH STREET
\end{tabular} & & LAGRANGE & 46761 & 4139065 & -8524493 & $\begin{array}{l}\text { MR. DAVID } \\
\text { DONATHEN }\end{array}$ & (219) 463-2042 & 1,459 & 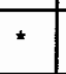 & 0.06 & & & LAGRANGE \\
\hline $\begin{array}{l}\text { LAGRANGE REGION } \\
\text { B WWTP }\end{array}$ & $\begin{array}{l}\text { LAGRANGE REGION } \\
\text { B WWTP }\end{array}$ & $\begin{array}{l}114 \mathrm{~W} . \\
\text { MICHIGAN ST } \\
\end{array}$ & & LAGRANGE & 46761 & 416561 & -853683 & $\begin{array}{l}\text { MR. STEVE } \\
\text { WEIGEL, PRES. }\end{array}$ & & 1,460 & & 0.388 & 60 & $1 \mathrm{~L}$ & LAGRANGE \\
\hline LAKE ELIZA CD & LAKE ELIZA CD & $\begin{array}{l}\text { CIOMR. MIKE } \\
\text { NOVAK }\end{array}$ & \begin{tabular}{|l}
101 UTILITY \\
DRIVE
\end{tabular} & HEBRON & 46341 & 4125240 & -8709557 & MR. DAN JONES & (219) 988-4482 & - & & 0.412 & & & PORTER \\
\hline
\end{tabular}


Compilation Date: May, 2001

Indiana Clean Manufacturing Technology and Safe Materials Institute

Purdue University

West Lafayette, Indiana

(Updated 1/13/04)

\begin{tabular}{|c|c|c|c|c|c|c|c|c|c|c|c|c|c|c|c|}
\hline Facility Name & Mailing Name & Mailing Streel 1 & Mailing Street 2 & Mailing City & $\frac{\text { ZIP }}{\text { Code }}$ & Latitude & Longitude & $\begin{array}{l}\text { Official } \\
\text { Representative }\end{array}$ & $\begin{array}{l}\text { Official } \\
\text { Representative } \\
\text { Telephone } \\
\text { Number } \\
\end{array}$ & $\frac{\text { Pop }}{(2000)}$ & $\underline{\mathrm{CS}}$ & Q Desian & $\underline{\frac{\%}{\operatorname{San}}}$ & $\%$ Ind & County \\
\hline $\begin{array}{l}\text { LAKE MONROE } \\
\text { RWD }\end{array}$ & $\begin{array}{l}\text { LAKE MONROE } \\
\text { RWD (STINESVILLE) }\end{array}$ & $\begin{array}{l}\text { STINESVILLE } \\
\text { PLANT } \\
\end{array}$ & $\begin{array}{l}519 \text { SOUTH } \\
\text { SALE ST. }\end{array}$ & ELLETTSVILLE & 47429 & 3903558 & -8627227 & $\begin{array}{l}\text { MR. JOHN } \\
\text { TROTTER }\end{array}$ & (812) 824-9005 & 194 & & 0.036 & 100 & & MONROE \\
\hline $\begin{array}{l}\text { LAKE MONROE } \\
\text { RWD (CASLON) }\end{array}$ & $\begin{array}{l}\text { LAKE MONROE } \\
\text { RWD (CASLON) }\end{array}$ & \begin{tabular}{|l} 
CASLON \\
WASTEWATER \\
TREAT. PLT. \\
\end{tabular} & $\begin{array}{l}519 \text { SOUTH } \\
\text { SALE }\end{array}$ & ELLETTSVILLE & 47429 & 392791 & -866141 & $\begin{array}{l}\text { MR. JOHN } \\
\text { TROTTER }\end{array}$ & (812) 824-9005 & 375 & & 0.3 & 100 & & MONROE \\
\hline $\begin{array}{l}\text { LAKE OF THE } \\
\text { WOODS RSD }\end{array}$ & $\begin{array}{l}\text { LAKE OF THE } \\
\text { WOODS REG SEW } \\
\text { DIST }\end{array}$ & P.O. BOX 455 & & BREMEN & 46506 & 4126190 & -8612250 & $\begin{array}{l}\text { MR. DENNIS } \\
\text { WEAVER, } \\
\text { PRESIDENT }\end{array}$ & (219) 546-2318 & - & & 0.059 & 100 & & MARSHALL \\
\hline \begin{tabular}{|l|} 
LAKEVILLE \\
MUNICIPAL WWTP \\
\end{tabular} & $\begin{array}{l}\text { LAKEVILLE } \\
\text { MUNICIPAL WWTP }\end{array}$ & P. O. BOX 137 & & LAKEVILLE & 46536 & 4131389 & -8615121 & MR. DAN CASAD & (219) 784-8311 & 567 & & 0.13 & & & SAINT JOSEPH \\
\hline LANESVILLE WWTP & LANESVILLE WWTP & P. O. BOX 6 & & LANESVILLE & 47136 & 3814029 & -8600075 & $\begin{array}{l}\text { MR. KENNETH } \\
\text { BROWN } \\
\end{array}$ & (812) 952-3037 & 614 & & 0.105 & 100 & & HARRISON \\
\hline $\begin{array}{l}\text { LAPAZ MUNICIPAL } \\
\text { WWTP }\end{array}$ & $\begin{array}{l}\text { LAPAZ MUNICIPAL } \\
\text { WWTP }\end{array}$ & P.O. BOX 820 & & LAPAZ & 46537 & 4126273 & -8617571 & $\begin{array}{l}\text { MR. WILLIAM D. } \\
\text { REED }\end{array}$ & (219) 784-8129 & 489 & & 0.129 & 100 & & MARSHALL \\
\hline $\begin{array}{l}\text { LAPEL MUNICIPAL } \\
\text { WWTP } \\
\end{array}$ & $\begin{array}{l}\text { LAPEL MUNICIPAL } \\
\text { STP }\end{array}$ & $\begin{array}{l}705 \text { WEST } \\
\text { PENDLETON }\end{array}$ & & LAPEL & 46051 & 4004153 & -8551228 & C.J. TAYLOR & (765) 534-3138 & 1,855 & & 0.36 & 78 & 23 & MADISON \\
\hline $\begin{array}{l}\text { LAPORTE } \\
\text { MUNICIPAL STP }\end{array}$ & $\begin{array}{l}\text { MAPORTE } \\
\text { MUNICIPALSTR }\end{array}$ & $\begin{array}{l}801 \mathrm{~W} U 1 \mathrm{H} I \mathrm{GAN} \\
\mathrm{AVE} \text {. }\end{array}$ & (3) & BPORTE & 46350 & 4135100 & $8641220^{\circ}$ & MR IERRYP & (219) $362-2354$ & $21621 \times$ & + & 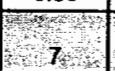 & 80 & 34 & LA PORTE \\
\hline $\begin{array}{l}\text { LAUREL MUNICIPAL } \\
\text { WWTP }\end{array}$ & $\begin{array}{l}\text { LAUREL MUNICIPAL } \\
\text { WWTP }\end{array}$ & $\begin{array}{l}\text { P.O. BOX 232, } \\
\text { PEARL STREET }\end{array}$ & & LAUREL & 47024 & 3929470 & -8511168 & $\begin{array}{l}\text { MR. RON } \\
\text { MIDDLETON }\end{array}$ & $(317) 698-2723$ & 579 & & 0.15 & 100 & & FRANKLIN \\
\hline $\begin{array}{l}\text { LEAVENWORTH } \\
\text { MUNICIPAL WWTP }\end{array}$ & $\begin{array}{l}\text { LEAVENWORTH } \\
\text { WWTP }\end{array}$ & R.R. 1, BOX 51 & & LEAVENWORTH & 47137 & 3812109 & -8620190 & $\begin{array}{l}\text { MR. JOHN } \\
\text { STUTSMAN, } \\
\text { PRES. }\end{array}$ & (812) 739-4850 & 353 & & 0.07 & 100 & 75 & CRAWFORD \\
\hline LEBANON WWTP & LEBANON UTAUTCS & $\begin{array}{l}201 \cdot E \text { MAIN } \\
\text { STREE }\end{array}$ & $1000 \times 479$ & L EBANON: & 46052 & 4003054 & 8628564 & WAR ROBERTE & $(765) 482-8016$ & 14,222 & & 280 & 100 & 9 & BOONE \\
\hline $\begin{array}{l}\text { LIBERTY } \\
\text { MUNICIPAL WWTP }\end{array}$ & $\begin{array}{l}\text { LIBERTY MUNICIPAL } \\
\text { WWTP } \\
\end{array}$ & P. O. BOX 7 & & LIBERTY & 47353 & 3938184 & -8456172 & $\begin{array}{l}\text { MR. DAVID } \\
\text { WOESTE }\end{array}$ & (765) 458-6738 & 2,061 & & 0.43 & 100 & & UNION \\
\hline $\begin{array}{l}\text { LIGONIER } \\
\text { MUNICIPAL WWTP }\end{array}$ & $\begin{array}{l}\text { CITY OF LIGONIER } \\
\text { STP }\end{array}$ & \begin{tabular}{|l|}
103 WEST \\
THIRD STREET \\
\end{tabular} & & LIGONIER & 46767 & 4128018 & -8535553 & $\begin{array}{l}\text { MR. DON } \\
\text { SKINNER }\end{array}$ & (219) $894-4233$ & 4,357 & * & 0.52 & 25 & 50 & NOBLE \\
\hline $\begin{array}{l}\text { LINDEN MUNICIPAL } \\
\text { WWTP }\end{array}$ & LINDEN WWTP & P.O. BOX 352 & & LINDEN & 47955 & 4011180 & -8654120 & $\begin{array}{l}\text { MR. JAMES } \\
\text { GOBLE }\end{array}$ & (765) 339-4746 & 700 & & 0.1 & & & MONTGOMERY \\
\hline $\begin{array}{l}\text { LINTON MUNICIPAL } \\
\text { WWTP }\end{array}$ & $\begin{array}{l}\text { LINTON MUNICIPAL } \\
\text { STP }\end{array}$ & $\begin{array}{l}86 \text { SOUTH MAIN } \\
\text { STREET }\end{array}$ & & LINTON & 47441 & 3901552 & -8708475 & MR. DAVID FISH & $(812) 847-9220$ & 5,774 & & 1.3 & 100 & 75 & GREENE \\
\hline $\begin{array}{l}\text { LITTLE RACCOON } \\
\text { RSD }\end{array}$ & $\begin{array}{l}\text { LITTLE RACCOON } \\
\text { RSD } \\
\end{array}$ & P.O. BOX 14 & & WAVELAND & 47989 & 3952300 & -8702400 & $\begin{array}{l}\text { MR. DOUG } \\
\text { CLODFELTER }\end{array}$ & (765) 435-2185 & - & & 1 & 100 & & MONTGOMERY \\
\hline $\begin{array}{l}\text { LIZTON MUNICIPAL } \\
\text { WWTP }\end{array}$ & $\begin{array}{l}\text { TOWN OF LIZTON } \\
\text { STP }\end{array}$ & P. О. воX 136 & & LIZTON & 46149 & 3952414 & -8632409 & $\begin{array}{l}\text { MR. JOHN R. } \\
\text { SEMENICK }\end{array}$ & (317) 994-5600 & 372 & & 0.08 & 100 & & HENDRICKS \\
\hline $\begin{array}{l}\text { LOGANSPORT } \\
\text { WWTP }\end{array}$ & $\begin{array}{l}\text { LOGANSPORT } \\
\text { MUNICIPAL WWTP }\end{array}$ & $\begin{array}{l}\text { G01 EV } \\
\text { BROAOWAY }\end{array}$ & ROOM 101 & LOGANSPORT & 46947 & 404560 & 8623190 & $\begin{array}{l}\text { MRPPAUL } \\
\text { HARTMAN }\end{array}$ & (219) $753-6234$ & 19,684 & 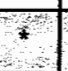 & 12 & 6 & 56 & CASS \\
\hline $\begin{array}{l}\text { LOOGOOTEE } \\
\text { WWTP }\end{array}$ & \begin{tabular}{|l} 
LOOGOOTEE \\
MUNICIPAL STP \\
\end{tabular} & 401 JFK AVE. & & LOOGOOTEE & 47553 & 3839535 & -8654382 & $\begin{array}{l}\text { MR. JAMES E. } \\
\text { WILSON }\end{array}$ & (812) 295-3060 & 2,741 & & 0.586 & 100 & & MARTIN \\
\hline LOWELL WWTP & $\begin{array}{l}\text { TOWN OF LOWELL } \\
\text { WWTP }\end{array}$ & PO BOX 157 & $\begin{array}{l}501 \text { EMAIN } \\
\text { STREET }\end{array}$ & LOWEL & 46356 & 4115515 & 8725030 & $\begin{array}{l}\text { MR ROBERT } \\
\text { HATCH }\end{array}$ & $\mid(219) 696-0343$ & 7,505 & & 4 & 90 & & LAKE \\
\hline
\end{tabular}


Directory of Indiana POTWs Compiled from EPAIDEM Files

Compilation Date: May, 2001

Indiana Clean Manufacturing Technology and Safe Materials Institute

Purdue University

West Lafayette, Indiana

(Updated 1/13/04)

\begin{tabular}{|c|c|c|c|c|c|c|c|c|c|c|c|c|c|c|c|}
\hline Facility Name & Mailing Name & Mailing Streel 1 & Mailing Street 2 & Mailing City & $\frac{Z I P}{\text { Code }}$ & Latitude & Longitude & $\begin{array}{l}\text { Official } \\
\text { Representative }\end{array}$ & \begin{tabular}{|l|} 
Official \\
Representative \\
Telephone \\
Number \\
\end{tabular} & $\frac{\text { Pop }}{(2000)}$ & CS & Q Design & $\underline{\frac{\%}{\operatorname{San}}}$ & $\%$ ind & $\underline{\text { County }}$ \\
\hline $\begin{array}{l}\text { LYNN MUNICIPAL } \\
\text { WWTP }\end{array}$ & $\begin{array}{l}\text { TOWN OF LYNN } \\
\text { MUNICIPAL STP }\end{array}$ & $\begin{array}{l}1468 \text { EAST C.R. } \\
\text { 900 SOUTH }\end{array}$ & & LYNN & 47355 & 4002046 & -8456598 & MR. DAVE WEIST & (317) 874-1929 & 1,143 & & 0.25 & 100 & 1 & RANDOLPH \\
\hline $\begin{array}{l}\text { LYNNVILLE } \\
\text { MUNICIPAL WWTP }\end{array}$ & LYNNVILLE WWTP & \begin{tabular}{|l|}
11455 \\
SPURGEON RD
\end{tabular} & & LYNNVILLE & 47619 & 3812006 & -8717268 & $\begin{array}{l}\text { JOSEPH POTTS, } \\
\text { CERT. OPER. } \\
\end{array}$ & (812) 922-5182 & 781 & & 0.08 & 100 & & WARRICK \\
\hline $\begin{array}{l}\text { LYONS MUNICIPAL } \\
\text { WWTP }\end{array}$ & $\begin{array}{l}\text { LYONS MUNICIPAL } \\
\text { WWTP }\end{array}$ & P.O. BOX 267 & \begin{tabular}{|l|}
150 EAST \\
BROAD ST \\
\end{tabular} & LYONS & 47443 & 3858215 & -8704456 & $\begin{array}{l}\text { MR. GREG } \\
\text { STALLINGS } \\
\end{array}$ & (812) 659-2521 & 748 & & 0.09 & 100 & & GREENE \\
\hline MADISON WWTP & $\begin{array}{l}\text { MADISON } \\
\text { MUNIEIPAL WWTP }\end{array}$ & $\begin{array}{l}46 \text { WEST } \\
\text { STREET }\end{array}$ & 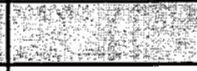 & MADISON & 47250 & 88441414 & 8523491 & $\begin{array}{l}\text { MRO DAVD } \\
\text { MAKINS }\end{array}$ & (812) 265-8328 & 12,004 & $\%$ & 36 & 72 & 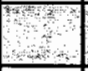 & JEEEERSON \\
\hline $\begin{array}{l}\text { MARENGO } \\
\text { MUNICIPAL WWTP }\end{array}$ & $\begin{array}{l}\text { MARENGO } \\
\text { MUNICIPAL WWTP }\end{array}$ & P.O. BOX 253 & & MILLTOWN & 47145 & 3822078 & -8619517 & TONY KAY & (812) 365-2156 & 829 & & 0.11 & & & CRAWFORD \\
\hline $\begin{array}{l}\text { MARION HEIGHTS } \\
C D\end{array}$ & $\begin{array}{l}\text { MARION HEIGHTS } \\
\text { CD }\end{array}$ & P.O. BOX 29 & & $\begin{array}{l}\text { ST. MARY-OF-THE- } \\
\text { WOODS }\end{array}$ & 47876 & 4046000 & -8555000 & $\begin{array}{l}\text { MS. BECKY } \\
\text { PITTMAN }\end{array}$ & (812) 533-1940 & - & & 0 & & & GRANT \\
\hline $\begin{array}{l}\text { MARKLE MUNICIPAL } \\
\text { WWTP }\end{array}$ & $\begin{array}{l}\text { MARKLE MUNICIPAL } \\
\text { WWTP }\end{array}$ & P. O. BOX 367 & \begin{tabular}{|l|}
155 SPARKS \\
STREET
\end{tabular} & MARKLE & 46770 & 4049336 & -8520366 & $\begin{array}{l}\text { MR. SCOTT } \\
\text { SPAHR }\end{array}$ & (219) 758-3192 & 1,102 & * & 0.151 & 90 & 3 & HUNTINGTON \\
\hline $\begin{array}{l}\text { NAR } \\
\text { WW W }\end{array}$ & $\begin{array}{l}\text { MARTINSVILLE } \\
\text { MUNICIPAL STP }\end{array}$ & $000 \times 1415$ & & MARTINSVITE & 46151 & 392462 & 162706 & MAPACLOCOLA & $(765) 3422342$ & 11,698 & & 22 & 90 & 20 & MORGAA: \\
\hline $\begin{array}{l}\text { MATTHEWS } \\
\text { MUNICIPAL WWTP }\end{array}$ & $\begin{array}{l}\text { MATTHEWS } \\
\text { MUNICIPAL STP }\end{array}$ & BOX 152 & & MATTHEWS & 46957 & 4024022 & -8530344 & \begin{tabular}{|l|} 
MR. WAYNE \\
RITENOUR
\end{tabular} & (765) 998-7028 & 595 & & 0.11 & 100 & & GRANT \\
\hline MCEORES VA & 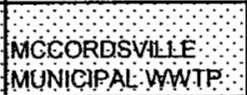 & PENG W W & & MoCoROSVHE & 46055 & $39007 \mathrm{i}$ & 8555342 & MRARONALD & & 1134 & & 0311 & & & HANCOCOK \\
\hline $\begin{array}{l}\text { MEDARWILLE } \\
\text { MUNICIPAL STP }\end{array}$ & $\begin{array}{l}\text { MEDARYVILLE } \\
\text { MUNICIPAL STP } \\
\end{array}$ & $\begin{array}{l}\text { NORTH MAPLE } \\
\text { STREET } \\
\end{array}$ & P.O. BOX 10 & MEDARYVILLE & 47957 & 410851 & -868729 & \begin{tabular}{|l} 
JERRY \\
BEISWANGER \\
\end{tabular} & (219) 843-2101 & 565 & & 0.067 & & & PULASKI \\
\hline MEDORA WWTP & MEDORA WWTP & P. O. BOX 247 & & MEDORA & 47260 & 3849070 & -8610501 & $\begin{array}{l}\text { MR. MELVIN } \\
\text { HUNSUCKER }\end{array}$ & (812) 966-2281 & 565 & & 0.18 & 100 & & JACKSON \\
\hline $\begin{array}{l}\text { MENTONE } \\
\text { MUNICIPAL WWTP }\end{array}$ & $\begin{array}{l}\text { MENTONE } \\
\text { MUNICIPAL WWTP }\end{array}$ & $\begin{array}{l}\text { TOWN OF } \\
\text { MENTONE }\end{array}$ & P.O. BOX 562 & MENTONE & 46539 & 4110546 & -8603144 & $\begin{array}{l}\text { MR. BRIAN REED, } \\
\text { CERT. OPER. }\end{array}$ & (219) 353-7554 & 898 & & 0.12 & 100 & & KOSCIUSKO \\
\hline $\begin{array}{l}\text { MEROM MUNICIPAL } \\
\text { WWTP }\end{array}$ & $\begin{array}{l}\text { MEROM MUNICIPAL } \\
\text { WWTP }\end{array}$ & P.O. BOX 165 & & MEROM & 47861 & 390138 & -875230 & $\begin{array}{l}\text { MR. DEAN E. } \\
\text { SPRINGER }\end{array}$ & (812) 356-4601 & 294 & & & & & SULLIVAN \\
\hline $\begin{array}{l}\text { MERR } \\
\text { WWLL }\end{array}$ & MERRILLVYLE CD & BROADWAY & & MERBHLS VILE & 46410 & 4130148 & 8720118 & $\begin{array}{l}\text { MS EHRISTINE } \\
\text { SAVARESE }\end{array}$ & (210) $980-5220$ & $30 ; 560$ & & & & & AKE \\
\hline $\begin{array}{l}\text { MICHIGANTOWN } \\
\text { MUNICIPAL WWTP }\end{array}$ & $\begin{array}{l}\text { MICHIGANTOWN } \\
\text { MUNICIPAL STP }\end{array}$ & MAIN STREET & P.O. BOX 27 & MICHIGANTOWN & 46057 & 4019419 & -8624083 & $\begin{array}{l}\text { MR. JEFF } \\
\text { STRONG }\end{array}$ & (765) 249-2948 & 406 & & 0.06 & 100 & & CLINTON \\
\hline $\begin{array}{l}\text { MIDDLEBURY } \\
\text { WWTP }\end{array}$ & $\begin{array}{l}\text { TOWN OF } \\
\text { MIDDLEBURY STP }\end{array}$ & P. O. BOX 812 & $\begin{array}{l}117 \text { N. MAIN } \\
\text { STREET }\end{array}$ & MIDDLEBURY & 46540 & 4141022 & -8542244 & MR. BRAD CLARK & (219) 825-1499 & 2,956 & & 0.5 & 100 & & ELKHART \\
\hline $\begin{array}{l}\text { MIDDLETOWN } \\
\text { MUNICIPAL WWTP }\end{array}$ & $\begin{array}{l}\text { MIDDLETOWN } \\
\text { MUNICIPAL WWTP }\end{array}$ & $\begin{array}{l}653 \text { LOCUST } \\
\text { STREET }\end{array}$ & & MIDDLETOWN & 47357 & 4003000 & -8532000 & $\begin{array}{l}\text { MR. JAMES } \\
\text { HANSON, PRES. }\end{array}$ & (765) 354-4441 & 2,488 & $\star$ & 0.5 & 0 & & HENRY \\
\hline MILAN WWTP & $\begin{array}{l}\text { MILAN MUNICIPAL } \\
\text { WWTP }\end{array}$ & P. O. BOX 86 & & MILAN & 47031 & 3907074 & -8507398 & $\begin{array}{l}\text { MR. JOHN } \\
\text { INGRAM, TOWN } \\
\text { MGR. } \\
\end{array}$ & (812) 654-2710 & 1,816 & & 0.195 & 40 & & RIPLEY \\
\hline MILFORD WWTP & $\begin{array}{l}\text { MILFORD JUNCTION } \\
\text { MUNICIPAL STP } \\
\end{array}$ & $\begin{array}{l}901 \text { WEST } 1250 \\
\text { NORTH }\end{array}$ & & MILFORD & 46542 & 4124480 & -8551562 & $\begin{array}{l}\text { DALLAS L. } \\
\text { WINCHESTER }\end{array}$ & (219) 658-4614 & 1,550 & * & 0.225 & 85 & 15 & KOSCIUSKO \\
\hline $\begin{array}{l}\text { MILLERSBURG } \\
\text { WWTP }\end{array}$ & $\begin{array}{l}\text { MILLERSBURG } \\
\text { MUNICIPAL STP }\end{array}$ & P.O. BOX 278 & & MILLLERSBURG & 46543 & 4131363 & -8541068 & MR. JEFF TAYLOR & (219) 642-3670 & 868 & & 0.12 & 100 & & ELKHART \\
\hline
\end{tabular}


Directory of Indiana POTWs Compiled from EPAIDEM Files

Compilation Date: May, 2001

Indiana Clean Manufacturing Technology and Safe Materials Institute

Purdue University

West Lafayette, Indiana

(Updated 1/13/04)

\begin{tabular}{|c|c|c|c|c|c|c|c|c|c|c|c|c|c|c|c|}
\hline Facility Name & Mailing Name & Mailing Street 1 & Mailing Street 2 & Mailing City & $\begin{array}{l}\text { ZIP } \\
\text { Code }\end{array}$ & Latitude & Longitude & $\begin{array}{l}\text { Official } \\
\text { Representative }\end{array}$ & $\begin{array}{l}\text { Official } \\
\text { Representative } \\
\text { Telephone } \\
\text { Number } \\
\end{array}$ & $\frac{\text { Pop }}{(2000)}$ & $\underline{\mathrm{CS}}$ & Q Design & $\underline{\frac{\%}{\operatorname{San}}}$ & $\%$ ind & County \\
\hline $\begin{array}{l}\text { MILLTOWN } \\
\text { MUNICIPAL WWTP } \\
\end{array}$ & $\begin{array}{l}\text { MILLTOWN } \\
\text { MUNICIPAL WWTP }\end{array}$ & RT. \#1 & & MILLTOWN & 47145 & 3820106 & -8615581 & MR. TONY KAY & (812) 633-4848 & 932 & & 0.15 & 100 & & CRAWFORD \\
\hline MISHAWAKA WWIP & $\begin{array}{l}\text { MISHAWAKA } \\
\text { MUNICIPAL WWTP }\end{array}$ & 600 E THIRD ST & (a) & MISHAWAKA & 46544 & 4139398 & 861327 & $\begin{array}{l}\text { HONROBERTCA } \\
\text { BEUTTER }\end{array}$ & $(219) 258,655$ & 46,557 & 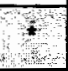 & 12 & 20 & 22 & SAINT JOSEPH \\
\hline $\begin{array}{l}\text { MITCHELL } \\
\text { MUNICIPAL WWTP } \\
\end{array}$ & $\begin{array}{l}\text { MITCHELL } \\
\text { MUNICIPAL STP }\end{array}$ & $\begin{array}{l}\text { 407 SOUTH } 6 \text { TH } \\
\text { STREET }\end{array}$ & & MITCHELL & 47446 & 3844267 & -8627394 & $\begin{array}{l}\text { MR. RUSSELL } \\
\text { EDMONDSON }\end{array}$ & (812) 849-4130 & 4,567 & & 0.565 & 90 & & LAWRENCE \\
\hline MONON WWTP & $\begin{array}{l}\text { MONON MUNICIPAL } \\
\text { STP }\end{array}$ & $\begin{array}{l}522 \text { N. MARKET } \\
\text { STREET } \\
\end{array}$ & P.O. BOX 657 & MONON & 47959 & 4051277 & -8652301 & MR. DAVE SCOTT & (219) 253-6275 & 1,733 & & 0.2193 & 100 & 3 & WHITE \\
\hline $\begin{array}{l}\text { MONROE CITY } \\
\text { WWTP } \\
\end{array}$ & $\begin{array}{l}\text { MONROE CITY } \\
\text { MUNICIPAL STP }\end{array}$ & P.O. BOX 163 & & IMONROE CITY & 47557 & 3836002 & -8720509 & $\begin{array}{l}\text { MR. JEREMY T. } \\
\text { MCCARTER }\end{array}$ & (812) 743-2976 & 548 & & 0.12 & 100 & & KNOX \\
\hline $\begin{array}{l}\text { MONROEVILLEE } \\
\text { MUNICIPAL WWTP }\end{array}$ & $\begin{array}{l}\text { MONROEVILLE } \\
\text { MUNICIPAL STP }\end{array}$ & P. O. BOX 401 & & MONROEVILLE & 46773 & 4058142 & -8451258 & $\begin{array}{l}\text { MR. BARRY } \\
\text { SCHERER }\end{array}$ & (219) 623-3197 & 1,236 & & 0.144 & 100 & & ALLEN \\
\hline MONROVIA POTW & $\begin{array}{l}\text { TOWN OF } \\
\text { MONROVIA }\end{array}$ & PO BOX 400 & & MONROVIA & 46157 & 395716 & -865193 & $\begin{array}{l}\text { SHAWN } \\
\text { MASSINGALE }\end{array}$ & & 628 & & 0.085 & & & MORGAN \\
\hline $\begin{array}{l}\text { MONTGOMERY } \\
\text { MUNICIPAL WWTP }\end{array}$ & $\begin{array}{l}\text { MONTGOMERY } \\
\text { MUNICIPAL STP }\end{array}$ & P. O. BOX 57 & & MONTGOMERY & 47558 & 3840002 & -8702012 & $\begin{array}{l}\text { MR. JAMES } \\
\text { O'BRIEN, PRES. }\end{array}$ & $(812)$ 486-3298 & 368 & & 0.09 & 100 & & DAVIESS \\
\hline $\begin{array}{l}\text { MONTICELLO } \\
\text { WWTP } \\
\end{array}$ & $\begin{array}{l}\text { MONTICELLO } \\
\text { MUNICIPAL STP }\end{array}$ & $\begin{array}{l}120 \text { WEST } \\
\text { WASHINGTON }\end{array}$ & & MONTICELLO & 47960 & 4044096 & -8645213 & $\begin{array}{l}\text { MR. ROGER M. } \\
\text { REED }\end{array}$ & (219) 583-7847 & 5,723 & ${ }^{*}$ & 0.95 & & & WHITE \\
\hline $\begin{array}{l}\text { MONTPELIER } \\
\text { MUNICIPAL, WWTP } \\
\end{array}$ & $\begin{array}{l}\text { MONTPELIER } \\
\text { MUNICIPAL STP }\end{array}$ & \begin{tabular}{|l|}
7611 NORTH 450 \\
EAST
\end{tabular} & & MONTPELIER & 47359 & 4034020 & -8517222 & $\begin{array}{l}\text { HON. THOMAAS E. } \\
\text { MCGEATH }\end{array}$ & (317) 728-5388 & 1,929 & * & 0.28 & 0 & 25 & BLACKFORD \\
\hline $\begin{array}{l}\text { MOORELAND } \\
\text { MUNICIPAL WWTP } \\
\end{array}$ & $\begin{array}{l}\text { MOORELAND } \\
\text { MUNICIPAL STP }\end{array}$ & P. O. BOX 33 & $\begin{array}{l}\text { CHARLES } \\
\text { STREET }\end{array}$ & MOORELAND & 47360 & 3958361 & -8514508 & $\begin{array}{l}\text { MR. RAYMOND } \\
\text { PERDUE, PRES. }\end{array}$ & (765) $766-5196$ & 393 & & 0.055 & 100 & & HENRY \\
\hline $\begin{array}{l}\text { MOORES HILL } \\
\text { WWTP }\end{array}$ & $\begin{array}{l}\text { MOORES HILL } \\
\text { MUNICIPAL WWTP }\end{array}$ & $\begin{array}{l}\text { TOWN OF } \\
\text { MOORES HILL }\end{array}$ & DURBIN RD. & MOORES HILL & 47032 & 3906223 & -8505398 & $\begin{array}{l}\text { MR. WILLIAM } \\
\text { LOVINS }\end{array}$ & (812) 654-2766 & 635 & & 0.1 & 100 & & DEARBORN \\
\hline MOQRESVILLE & MOOORESVILLE & $\begin{array}{l}\text { TOWN HALL 26: } \\
\text { SINDANA ST }\end{array}$ & & MOORESVILE & 46158 & 3936174 & 8622040 & MR DANTINGGE & $(311) 831-0625$ & 9273 & & 1,5 & 100 & 10 & MORGAA \\
\hline $\begin{array}{l}\text { MORGANTOWN } \\
\text { WWTP }\end{array}$ & $\begin{array}{l}\text { TOWN OF } \\
\text { MORGANTOWN }\end{array}$ & $\begin{array}{l}120 \text { WEST } \\
\text { WASHINGTON }\end{array}$ & P.O. BOX 416 & MORGANTOWN & 46160 & 3921496 & -8616322 & $\begin{array}{l}\text { MS. EDNA } \\
\text { VAUGHT, PRES. }\end{array}$ & $(812) 597-4626$ & 964 & & 0.16 & 100 & & MORGAN \\
\hline $\begin{array}{l}\text { MORRISTOWN } \\
\text { MUNICIPAL WWTP }\end{array}$ & $\begin{array}{l}\text { MORRISTOWN } \\
\text { MUNICIPAL STP }\end{array}$ & P.O. BOX 389 & $\begin{array}{l}\text { 239 E. MAIN } \\
\text { STREET }\end{array}$ & MORRISTOWN & 46161 & 3940143 & -8542265 & \begin{tabular}{|l|} 
MR. DAVID \\
BENEFIEL, PRES.
\end{tabular} & (765) 763-6748 & 1,133 & & 0.255 & 100 & & SHELBY \\
\hline $\begin{array}{l}\text { MOUNT VERNON } \\
\text { WWTP }\end{array}$ & $\begin{array}{l}\text { MOUNT VERNON } \\
\text { MUNICIPAL STP }\end{array}$ & $\begin{array}{l}\text { 410 S. OLD } \\
\text { HIGHWAY } 69 \\
\end{array}$ & & MOUNT VERNON & 47620 & 3755267 & -8754383 & MR. MIKE STUCKI & (812) 838-8721 & 7,478 & * & 1.8 & 90 & & POSEY \\
\hline $\begin{array}{l}\text { MULBERRY } \\
\text { MUNICIPAL WWTP }\end{array}$ & $\begin{array}{l}\text { MULBERRY } \\
\text { MUNICIPAL STP }\end{array}$ & $\begin{array}{l}3689 \text { WEST C.R. } \\
350 \text { NORTH }\end{array}$ & & MULBERRY & 46058 & 4020103 & -8639403 & $\begin{array}{l}\text { MR. RANDY } \\
\text { COOPER }\end{array}$ & (765) 296-2455 & 1,387 & & 0.165 & 100 & & CLINTON \\
\hline MUNCIE WWTP & $\begin{array}{l}\text { MUNGIE MUNICIPAL } \\
\text { STP }\end{array}$ & $\begin{array}{l}5150 \text { KILGORE } \\
\text { AVE. }\end{array}$ & (3) & MUNEIE & 47304 & 4011030 & 8526310 & $\begin{array}{l}\text { MP MIGHAEEK } \\
\text { ROST }\end{array}$ & $(765)) 7474663$ & 67,430 & t & 24 & 20 & 12.5 & DELAWARE \\
\hline $\begin{array}{l}\text { NAPOLEON } \\
\text { MUNICIPAL STP }\end{array}$ & $\begin{array}{l}\text { NAPOLEON } \\
\text { MUNICIPAL STP }\end{array}$ & P.O. BOX 47 & & NAPOLEON & 47034 & 3912438 & -8519448 & $\begin{array}{l}\text { MR. JAMES R. } \\
\text { EATON }\end{array}$ & (812) 852-4552 & 238 & & 0.04 & 100 & & RIPLEY \\
\hline $\begin{array}{l}\text { NAPPANEE } \\
\text { MUNICIPAL STP }\end{array}$ & $\begin{array}{l}\text { NAPPANEE } \\
\text { MUNICIPAL STP }\end{array}$ & P.O. BOX 29 & $\begin{array}{l}300 \text { W. LINCOLN } \\
\text { ST }\end{array}$ & NAPPANEE & 46550 & 4126480 & -8559210 & $\begin{array}{l}\text { MR. PHILLIP } \\
\text { HOCHSTETLER }\end{array}$ & $(219)$ 773-3033 & 6.710 & * & 1.9 & & 15 & ELKHART \\
\hline $\begin{array}{l}\text { NASHVILLE } \\
\text { MUNICIPAL WWTP }\end{array}$ & $\begin{array}{l}\text { NASHVILLE } \\
\text { MUNICIPAL STP }\end{array}$ & P.O. BOX 446 & & NASHVILLE & 47448 & 3912156 & -8615095 & $\begin{array}{l}\text { MR. ROGER } \\
\text { KELSO }\end{array}$ & $(812) 988-5326$ & 825 & & 0.575 & 100 & & BROWN \\
\hline $\begin{array}{l}\text { NEW ALBANY } \\
\text { WWTP }\end{array}$ & $\begin{array}{l}\text { NEWALBANY } \\
\text { MUNGCPAL WWTP }\end{array}$ & HAU SS SQUARE & 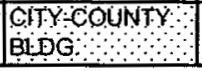 & NEW ALBANY & 47.50 & 3816407 & 86549548 & $\begin{array}{l}M R \text { TERRY } \\
\text { PENMNiMTóN }\end{array}$ & $\because 812948+5320$ & 37,603 & & 6878 & $\because$ & $\mathrm{do}$ & ELOY \\
\hline
\end{tabular}


Directory of Indiana POTWs Compiled from EPAIDEM File

Compilation Date: May, 2001

Indiana Clean Manufacturing Technology and Safe Materials Institute

Purdue University

West Lafayette, Indiana

(Updated 1/13/04)

\begin{tabular}{|c|c|c|c|c|c|c|c|c|c|c|c|c|c|c|c|}
\hline Facility Name & Mailing Name & Mailing Street 1 & Mailing Street 2 & Mailing City & $\begin{array}{l}\text { ZIP } \\
\text { Code }\end{array}$ & Latitude & Longitude & $\begin{array}{l}\text { Official } \\
\text { Representative }\end{array}$ & $\begin{array}{l}\text { Official } \\
\text { Representative } \\
\begin{array}{l}\text { Telephone } \\
\text { Number }\end{array} \\
\end{array}$ & $\frac{\text { Pop }}{(2000)}$ & CS & Q Desian & $\underline{\underline{\text { San }}}$ & \% ind & County \\
\hline $\begin{array}{l}\text { NEWCASTEE } \\
\text { WWTP }\end{array}$ & $\begin{array}{l}\text { NEWRCASTLE } \\
\text { MUNICIPAL STP }\end{array}$ & CITY HALL & $\begin{array}{l}\text { 321 S. MAIN } \\
\text { STREET }\end{array}$ & NEW CASTLE & 47362 & 3954510 & 8523320 & $\begin{array}{l}\text { MRGARIS } \\
\text { MAINES } \\
\end{array}$ & (317) $521-6836$ & 17,780 & \% & 8 & 100 & 5 & HENRY \\
\hline $\begin{array}{l}\text { NEW HARMONY } \\
\text { MUNICIPAL WWTP }\end{array}$ & 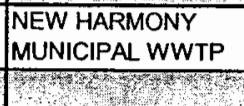 & P. O. BOX 275 & 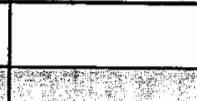 & NEW HARMONY & 47631 & 3807438 & -8756285 & \begin{tabular}{|l} 
JOHNW. \\
WILKERSON \\
TERRY
\end{tabular} & $(812) 682-4109$ & 916 & & 0.14 & 100 & & POSEY \\
\hline $\begin{array}{l}\text { NEW HAVEN WWTP } \\
\text { NEW LONDON C.D. }\end{array}$ & $\frac{\text { NEW HAVEN }}{\text { NEW LONDON C.D. }}$ & $\begin{array}{l}1235 \text { LINCOLN } \\
\text { HIGHWAYE } \\
\text { PO BOX } 207\end{array}$ & $80 B 0 \times 570$ & NEW HAVEN & 4677 & 4105100 & 8500500 & $\begin{array}{l}\text { MCDONAN, } \\
\text { MAYOR }\end{array}$ & (219) $799-1911$ & 12,406 & 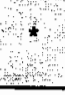 & 0.75 & & & ALLEN \\
\hline \begin{tabular}{|l|} 
NEW LONDON C.D. \\
NEW MARKET
\end{tabular} & $\begin{array}{l}\text { NEW LONDON C.D. } \\
\text { NEW MARKET }\end{array}$ & & & WEST MIDDLETON & 46995 & 4026467 & -8616300 & MR. JOE HILLIS & & - & & 0.02 & & & HOWARD \\
\hline $\begin{array}{l}\text { WWTP } \\
\text { AEWTPALESTINE : }\end{array}$ & MUNICIPAL STP & P.09. BOX 311 & & NEW MARKET & 47965 & 3957060 & -8655120 & $\begin{array}{l}\text { MR. DON ALLEN } \\
\text { YOUNT } \\
\text { MR:DAVIDEF }\end{array}$ & (765) 866-0111 & 659 & & 0.14 & 100 & & MONTGOMERY \\
\hline MiUNiCIPAL WWTS & WUUNICIPAL STP & PALESTNE -1 & $P O B O \times 315$ & NEW PALESTINE & 46163 & 3942489 & 8553193 & $\frac{M R}{\text { MOOK }}$ & (31) 1 ) 86144099 & 1,264 & & $0-15$ & $100:$ & & HANGQCK \\
\hline$\frac{\text { NEW PARIS GQ }}{\text { NEW PEKIN }}$ & NEW PARS CD: & TRUSTEES & $P 0$ BONo1 & NEW PARIS & 46553 & 44487 & 858489 & DAUSMAN & & & & 021 & & & ELKHART \\
\hline $\begin{array}{l}\text { MUNICIPAL WWTP } \\
\text { NEW RICHMOND }\end{array}$ & \begin{tabular}{|l} 
NEW PEKIN \\
MUNICIPAL STP \\
NEW RICHMOND
\end{tabular} & $\begin{array}{l}\text { TOWN OF NEW } \\
\text { PEKIN } \\
\text { TOWN OF NEW }\end{array}$ & P.O. BOX 315 & NEW PEKIN & 47165 & 3829548 & -8601259 & $\begin{array}{l}\text { MR. TIMOTHY } \\
\text { SMITH } \\
\end{array}$ & (812) 967-4106 & 1,334 & & 0.06 & 100 & 2 & WASHINGTON \\
\hline MUNICIPAL WWTP & \begin{tabular}{|l} 
MUNICIPAL WWTP \\
NEW ROSS TOWN
\end{tabular} & \begin{tabular}{|l|} 
RICHMOND \\
105 WEST
\end{tabular} & P.O. BOX 210 & NEW RICHMOND & 47967 & 401815 & -869845 & MR. KEITH SCOTT & & 349 & & 0.04 & & & MONTGOMERY \\
\hline $\begin{array}{l}\text { NEW ROSS WWTP } \\
\text { NEWWHALAND }\end{array}$ & $\begin{array}{l}\text { COUNCIL } \\
\text { NEW WHITELAND: }\end{array}$ & & & NEW ROSS & 47968 & 399956 & -867506 & MR. TOM TERRY & & 334 & & 0.033 & & & MONTGOMERY \\
\hline MUN & NEWITUARGH & GORG VANADA & & New vilitelesNo & 46184 & 39зазаз & 8606252 & $A B B O D$ & $(311) 5354464$ & 4,579 & & 45 & 100 & & jơnsón \\
\hline NEWBURGHWWTP & NOBIESSVILEE & ROAQ $\because$ & 16 SOUTH $10 \mathrm{TH}$ & NENBURH & 47630 & 3756311 & 872056 & $M R$ LEONKE & $(812) 853=6442$ & 3088 & & 25 & 100 & & WARQICK \\
\hline$\frac{\text { POL CONTROL P }}{\text { NORTH JUDSON }}$ & $\frac{\text { MUNICIPAL STP }}{\text { NORTH JUDSON }}$ & $\mathrm{CITYHAL}$, & $\frac{\text { STREEI }}{204 \text { KELLER }}$ & NOBLESVILE & 46060 & 4002168 & 8601120 & DONASE ANTHIS & $(317) 71666353$ & 28,590 & 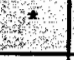 & 5 & 0.6 & 3 & HAMILTON \\
\hline $\begin{array}{l}\text { MUNICIPAL WWTP } \\
\text { NORTH LIBERTY }\end{array}$ & $\begin{array}{l}\text { MUNICIPAL STP } \\
\text { NORTH LIBERTY }\end{array}$ & P.O. BOX 56 & $\begin{array}{l}204 \text { KELLER } \\
\text { AVE. }\end{array}$ & NORTH JUDSON & 46366 & 4113231 & -8646327 & \begin{tabular}{|l|} 
MR. L. JAMES \\
SALLEE, PRES. \\
MR. DENNIS
\end{tabular} & (219) 896-3340 & 1,675 & * & 0.95 & & 4 & STARKE \\
\hline$\frac{\text { WWTP }}{\text { NORTH }}$ & \begin{tabular}{|l} 
MUNICIPAL STP \\
NORTH
\end{tabular} & MAIN & P.O. BOX 515 & NORTH LIBERTY & 46554 & 4132076 & -8626114 & WEA & (219) 656-3121 & 1,402 & & 0.18 & & 39 & SAINT JOSEPH \\
\hline $\begin{array}{l}\text { MANCHESTER } \\
\text { MUNICIPAL STP } \\
\end{array}$ & $\begin{array}{l}\text { MANCHESTER } \\
\text { MUNICIPAL STP }\end{array}$ & $\begin{array}{l}407 \text { EAST MAIN } \\
\text { STREET }\end{array}$ & & $\begin{array}{l}\text { NORTH } \\
\text { MANCHESTER } \\
\end{array}$ & 46962 & 4059380 & -8546240 & $\begin{array}{l}\text { MR. CHRIS } \\
\text { HARRISON }\end{array}$ & (219) 982-4070 & 6,260 & * & 1.25 & 5 & 10 & WABASH \\
\hline $\begin{array}{l}\text { NORTH SALEM } \\
\text { MUNICIPAL WWTP }\end{array}$ & $\begin{array}{l}\text { NORTH SALEM } \\
\text { MUNICIPAL STP }\end{array}$ & $\frac{\text { P.O. BOX } 417}{725 \text { NORTH }}$ & & NORTH SALEM & 46165 & 3951209 & -8638226 & $\begin{array}{l}\text { MR. DOUG } \\
\text { CLODFELTER }\end{array}$ & (765) 522-1165 & 591 & & 0.08 & 100 & & HENDRICKS \\
\hline $\begin{array}{l}\text { NORTH VERNON } \\
\text { WWTP } \\
\text { NORTH WEBSTER }\end{array}$ & $\begin{array}{l}\text { NORTH VERNON } \\
\text { STP } \\
\text { NORTH WEBSTER }\end{array}$ & $\begin{array}{l}\text { GREENSBURG } \\
\text { ROAD }\end{array}$ & 7203 EAST 650 & NORTH VERNON & 7265 & 300155 & -8536479 & $\begin{array}{l}\text { MR. THOMAS } \\
\text { SCHWING } \\
\text { CHRISTIANF }\end{array}$ & $(812) 346-5493$ & 6,515 & * & 1.75 & & & JENNINGS \\
\hline $\begin{array}{l}\text { NORTH WEBSTER } \\
\text { MUNICIPAL WWTP }\end{array}$ & MUNICIPAL STP & \begin{tabular}{|l} 
P.O. BOX 95 \\
4230 PORTAGE
\end{tabular} & & NORTH WEBSTER & 46555 & 4119405 & -8542220 & $\begin{array}{l}\text { CHRISTIANF. } \\
\text { FRANCE }\end{array}$ & $(219) 834-7241$ & 1,067 & & 0.3 & 100 & & KOSCIUSKO \\
\hline WWTP & MUNICIPAL STP & WASHINGTON & & OAKLAND CITY & 47660 & 3820141 & -8720139 & & (812) 749-3081 & 2,588 & & 0.55 & 100 & & GIBSON \\
\hline
\end{tabular}


Compilation Date: May, 2001

Indiana Clean Manufacturing Technology and Safe Materials Institute

Purdue University

West Lafayette, Indiana

(Updated 1/13/04)

\begin{tabular}{|c|c|c|c|c|c|c|c|c|c|c|c|c|c|c|c|}
\hline Facility Name & Mailing Name & Mailing Street 1 & Mailing Street 2 & Mailing City & ZIP & Latitude & Longitude & $\begin{array}{l}\text { Official } \\
\text { Representative }\end{array}$ & $\begin{array}{l}\text { Official } \\
\text { Representative } \\
\text { Telephone } \\
\text { Number } \\
\end{array}$ & $\frac{\text { Pop }}{(2000)}$ & $\underline{\mathrm{CS}}$ & Q Design & $\underline{\frac{\%}{\text { San }}}$ & $\%$ Ind & County \\
\hline $\begin{array}{l}\text { ODON MUNICIPAL } \\
\text { WWTP }\end{array}$ & $\begin{array}{l}\text { ODON MUNICIPAL } \\
\text { STP }\end{array}$ & \begin{tabular}{|l|}
109 SOUTH \\
SPRING STREET
\end{tabular} & & ODON & 47562 & 3850285 & -8700065 & MR. KEVIN BYRER & (812) 636-7755 & 1,376 & & 0.24 & 100 & & DAVIESS \\
\hline OLDENBURG STP & $\begin{array}{l}\text { OLDENBURG } \\
\text { MUNICIPAL WWTP }\end{array}$ & \begin{tabular}{|l} 
C/O RON \\
MIDDLETON \\
\end{tabular} & $\begin{array}{l}9097 \\
\text { HARNBURG RD }\end{array}$ & LAUREL & 47024 & 393907 & -852453 & \begin{tabular}{|l} 
MR. RON \\
MIDDLETON
\end{tabular} & (812) 934-2728 & 647 & & 0.144 & 100 & & FRANKLIN \\
\hline $\begin{array}{l}\text { OOLITIC MUNICIPAL } \\
\text { WWTP }\end{array}$ & $\begin{array}{l}\text { OOLITIC MUNICIPAL } \\
\text { STP }\end{array}$ & $\begin{array}{l}109 \text { MAIN } \\
\text { STREET }\end{array}$ & P.O. BOX 7 & OOLITIC & 47451 & 3853252 & -8631434 & $\begin{array}{l}\text { MR. DELVIN } \\
\text { NIKIRK, PRES. }\end{array}$ & (812) 279-2456 & 1,152 & & 0.18 & 100 & & LAWRENCE \\
\hline $\begin{array}{l}\text { ORLEANS } \\
\text { MUNICIPAL WWTP }\end{array}$ & ORLEANS WWTP & P.O. BOX 146 & $\begin{array}{l}161 \text { EAST } \\
\text { MONROE ST }\end{array}$ & ORLEANS & 47452 & 3839062 & -8627126 & $\begin{array}{l}\text { MR. DONALD } \\
\text { JENKINS }\end{array}$ & (812) $865-2858$ & 2,273 & & 0.25 & 100 & & ORANGE \\
\hline OSGOOD WWTP & OSGOOD STP & \begin{tabular}{|l}
160 NORTH \\
BUCKEYE ST
\end{tabular} & & OSGOOD & 47037 & 3908176 & -8516523 & $\begin{array}{l}\text { MR. ANTHONY J. } \\
\text { WOOD }\end{array}$ & (812) 689-4441 & 1,669 & & 0.35 & 100 & & RIPLEY \\
\hline $\begin{array}{l}\text { OSSIAN MUNICIPAL } \\
\text { WWTP }\end{array}$ & $\begin{array}{l}\text { OSSIAN MUNICIPAL } \\
\text { STP }\end{array}$ & P.O. BOX 558 & $\begin{array}{l}507 \mathrm{~N} . \\
\text { JEFFERSON }\end{array}$ & OSSIAN & 46777 & 4052383 & -8510204 & MR. PHILIP YAGER & (219) 622-4253 & 2,943 & * & 0.3 & 70 & & WELLS \\
\hline OTTERBEIN WWTP & $\begin{array}{l}\text { OTTERBIEN } \\
\text { MUNICIPAL STP }\end{array}$ & $\begin{array}{l}\text { TOWN BOARD } \\
\text { PRESIDENT }\end{array}$ & P. O. BOX 212 & OTTERBIEN & 47970 & 4029168 & -8705215 & $\begin{array}{l}\text { MR. DAN BROCK, } \\
\text { CERT. OPER. }\end{array}$ & (765) 583-0340 & 1,312 & & 0.17 & 100 & & BENTON \\
\hline $\begin{array}{l}\text { OWENSVILLLE } \\
\text { MUNICIPAL WWTP }\end{array}$ & $\begin{array}{l}\text { OWENSVILLE } \\
\text { MUNICIPAL STP }\end{array}$ & $\begin{array}{l}\text { SOUTH MILL } \\
\text { STREET }\end{array}$ & P.O. BOX 296 & OWENSVILLE & 47665 & 3815556 & -8741383 & MR. RANDY ROSS & $(812) 724-3909$ & 1,322 & & 0.14 & 100 & $>5$ & GIBSON \\
\hline $\begin{array}{l}\text { OXFORD } \\
\text { MUNICIPAL WWTP } \\
\text { SITE } 1\end{array}$ & $\begin{array}{l}\text { OXFORD } \\
\text { MUNICIPAL WWTP }\end{array}$ & 107 N. HOWARD & P.O. BOX 54 & OXFORD & 47971 & 4031060 & -8714480 & MR. ED MORRIS & |(765) 385-2455 & 1,271 & * & 0.15 & 40 & & BENTON \\
\hline $\begin{array}{l}\text { PALMYRA } \\
\text { MUNICIPAL WWTP }\end{array}$ & $\begin{array}{l}\text { PALMYRA } \\
\text { MUNICIPAL STP }\end{array}$ & P.O. BOX 332 & & PALMYRA & 47164 & 3824554 & -8607197 & $\begin{array}{l}\text { MR. DAVID } \\
\text { WILLIAMS }\end{array}$ & (812) 364-4853 & 633 & & 0.191 & 100 & & HARRISON \\
\hline $\begin{array}{l}\text { PAOLI MUNICIPAL } \\
\text { WWTP }\end{array}$ & PAOLI WWTP & $\begin{array}{l}\text { MUNICIPAL } \\
\text { BUILDING }\end{array}$ & $\begin{array}{l}110 \text { NORTH } \\
\text { GOSPEL ST }\end{array}$ & PAOLI & 47454 & 3833265 & -8629262 & $\begin{array}{l}\text { MR. KEITH } \\
\text { CONDRA }\end{array}$ & (812) $723-3479$ & 3,844 & * & 0.52 & 0.85 & & ORANGE \\
\hline $\begin{array}{l}\text { PARAGON } \\
\text { MUNICIPAL WWTP }\end{array}$ & $\begin{array}{l}\text { PARAGON } \\
\text { MUNICIPAL STP }\end{array}$ & P. O. BOX 66 & & PARAGON & 46166 & 3923002 & -8633513 & $\begin{array}{l}\text { MR. JOHN S. } \\
\text { TROTTER }\end{array}$ & (317) 537-2597 & 663 & & 0.067 & 100 & & MORGAN \\
\hline $\begin{array}{l}\text { PARKERCIRY } \\
\text { MUNGICIP WwTP }\end{array}$ & $\begin{array}{l}\text { PARKER CITY } \\
\text { MUUNICIPAC STP }\end{array}$ & M10 SO TH STRE & & PRKER CIT & 47368 & 4009436 & 8512472 & $\begin{array}{l}\text { MRAME } \\
\text { DECKMAN }\end{array}$ & र 64468994 & 1446 & & 024 & 100 & & RANDOLPH \\
\hline PATOKA LK RSD & PATOKA LK RSD & $\begin{array}{l}\text { EDWIN PIEPER, } \\
\text { PRESIDENT } \\
\end{array}$ & P.O. BOX 308 & DUBOIS & 47527 & 3825552 & -8646013 & $\begin{array}{l}\text { MR. BRUCE A } \\
\text { HEEKE }\end{array}$ & $(812) 678-5171$ & 749 & & 0.7 & 100 & 35 & DUBOIS \\
\hline PATRIOT WWTP & $\begin{array}{l}\text { PATRIOT } \\
\text { MUNICIPAL WWTP }\end{array}$ & P.O. BOX 146 & & PATRIOT & 47038 & 3850056 & -8449527 & $\begin{array}{l}\text { MR. DAVIS } \\
\text { THOMAS }\end{array}$ & $(812) 594-2757$ & 202 & & 0.03 & 100 & & SWITZERLAND \\
\hline $\begin{array}{l}\text { PENNVILLE } \\
\text { MUNICIPAL WWTP }\end{array}$ & $\begin{array}{l}\text { PENNVILLE } \\
\text { MUNICIPAL STP }\end{array}$ & P.O. BOX 227 & $\begin{array}{l}330 \text { WEST } \\
\text { RIVER ROAD }\end{array}$ & PENNVILLE & 47369 & 4029381 & -8509074 & $\begin{array}{l}\text { MR. GREG } \\
\text { BUCKNER }\end{array}$ & (765) 768-6401 & 706 & & 0.16 & 100 & & JAY \\
\hline PERU WWTP & PERU WWTP & \begin{tabular}{|l|}
335 EASTT \\
CANAL STREEI
\end{tabular} & (1) & $\mathrm{PERU}$ & 46970 & 404427 & 8604199 & $\begin{array}{l}\text { MRRIG } \\
\text { MARE }\end{array}$ & $(765), 473-7651$ & 12,994 & 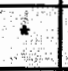 & 4 & 20 & 5 & WLAM \\
\hline $\begin{array}{l}\text { PETERSBURG } \\
\text { MUNICIPAL WWTP }\end{array}$ & $\begin{array}{l}\text { PETERSBURG } \\
\text { MUNICIPAL STP }\end{array}$ & CITY HALL & 704 MAIN ST. & PETERSBURG & 47567 & 3829348 & -8717314 & $\begin{array}{l}\text { MR. JERRYL. } \\
\text { BURTON }\end{array}$ & (812) 354-6691 & 2,570 & & 0.6 & 100 & & PIKE \\
\hline PIERCETON WWTP & $\begin{array}{l}\text { PIERCETON } \\
\text { MUNICIPAL STP }\end{array}$ & P. O. BOX 496 & & PIERCETON & 46562 & 4111268 & -8542115 & MR. BRET AKER & (219) 594-5882 & 695 & & 0.4 & 100 & & KOSCIUSKO \\
\hline PJT SBQRO WW & PITTSBORO & Po BOX 185 & $\begin{array}{l}\text { 80NORTH } \\
\text { MERIDANAS }\end{array}$ & PITSSBORO & 4697 & 3952201 & 8627224 & $\begin{array}{l}\text { MR BRUCEE } \\
\text { PENCE }\end{array}$ & $(317) 892-3328$ & A 588 & & 016 & 100 & & $\mathrm{HENGRCKS}$ \\
\hline $\begin{array}{l}\text { PLAINFIELD POL } \\
\text { CONTROI FACIL, }\end{array}$ & $\begin{array}{l}\text { PLAINFIELD } \\
\text { MUNICIPAL STP }\end{array}$ & $\begin{array}{l}986 \text { SOUTH } \\
\text { CENTER ST }\end{array}$ & 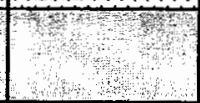 & PLAINEIELD & 46168 & 3941283 & 8623427 & $\begin{array}{l}\text { MR GEORGE } \\
\text { SAWVER CERT } \\
\text { OPER }\end{array}$ & $(317)$ 839.3883 & 18,396 & 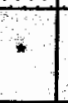 & 2.5 & 15 & 15 & HENDRICKS \\
\hline
\end{tabular}


Compilation Date: May, 2001

Indiana Clean Manufacturing Technology and Safe Materials Institute

Purdue University

West Lafayette, Indiana

(Updated 1/13/04)

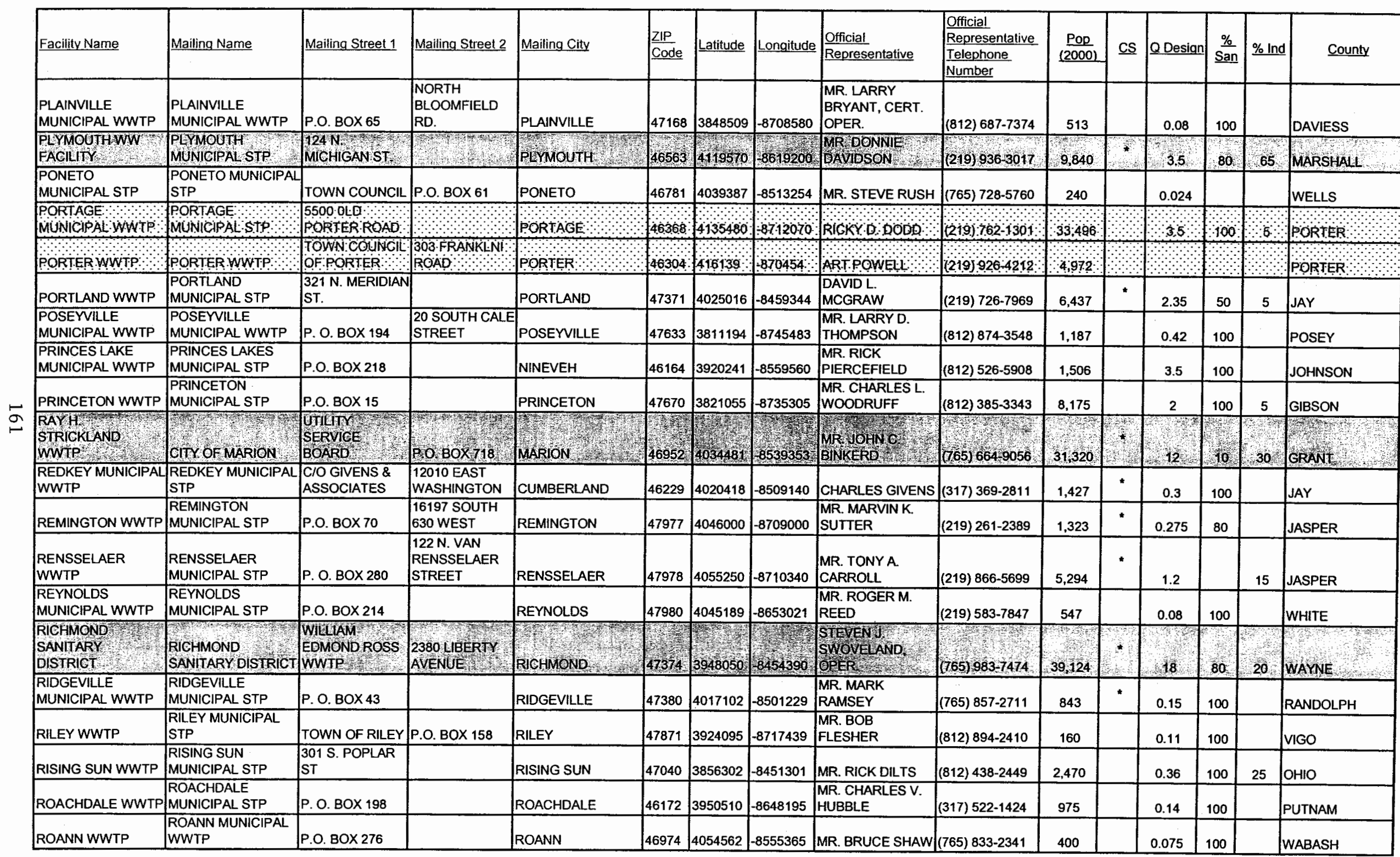


Directory of Indiana POTWs Compiled from EPAIDEM Files

Compilation Date: May, 2001

Indiana Clean Manufacturing Technology and Safe Materials Institute

Purdue University

West Lafayette, Indiana

(Updated 1/13/04)

\begin{tabular}{|c|c|c|c|c|c|c|c|c|c|c|c|c|c|c|c|}
\hline Facility Name & Mailing Name & Mailing Street 1 & Mailing Street 2 & Mailing City & $\frac{\text { ZIP }}{\text { Code }}$ & Latitude & Longitude & $\begin{array}{l}\text { Official } \\
\text { Representative }\end{array}$ & \begin{tabular}{|l|} 
Official \\
Representative \\
Telephone \\
Number \\
\end{tabular} & $\frac{\text { Pop }}{(2000)}$ & cs & Q Design & $\frac{\%}{\operatorname{San}}$ & $\%$ Ind & County \\
\hline SHERIDAN WWTP & $\begin{array}{l}\text { SHERIDAN } \\
\text { MUNICIPAL STP }\end{array}$ & 506 S. MAIN ST. & & SHERIDAN & 46069 & 4008140 & -8612374 & $\begin{array}{l}\text { MS. REBECCA A. } \\
\text { SIMS }\end{array}$ & (317) 758-5233 & 2,520 & & 0.5 & 100 & & HAMILTON \\
\hline $\begin{array}{l}\text { SHIPSHEWANA } \\
\text { WWTP } \\
\end{array}$ & $\begin{array}{l}\text { SHIPSHEWANA } \\
\text { MUNICIPAL STP }\end{array}$ & P.O. BOX 486 & & SHIPSHEWANA & 46565 & 4140583 & -8533553 & THOMAS COOK & (219) 768-7317 & 536 & & 0.15 & 100 & 10 & LAGRANGE \\
\hline SHIRLEY WWTP & $\begin{array}{l}\text { SHIRLEY } \\
\text { MUNICIPAL STP } \\
\end{array}$ & 212 MAIN & P.O. BOX 90 & SHIRLEY & 47384 & 3952552 & -8535539 & $\begin{array}{l}\text { MR. DAVID } \\
\text { RESLER } \\
\end{array}$ & $(317) 737-6561$ & 806 & & 0.16 & 85 & & HENRY \\
\hline $\begin{array}{l}\text { SILVER LAKE } \\
\text { MUNICIPAL WWTP }\end{array}$ & $\begin{array}{l}\text { SILVER LAKE } \\
\text { MUNICIPAL STP } \\
\end{array}$ & P.O. BOX 176 & ETIGNT & SILVER LAKE & 46982 & 4104019 & -8554168 & $\begin{array}{l}\text { MR. PHIL } \\
\text { SHALLEY }\end{array}$ & (219) $352-2120$ & 546 & & 0.1 & 100 & & KOSCIUSKO \\
\hline $\begin{array}{l}\text { SOUTHBEND } \\
\text { MUNICIPAL STP }\end{array}$ & $\begin{array}{l}\text { SOGTEBEND } \\
\text { MUNICIPAL STP }\end{array}$ & $\begin{array}{l}227 \mathrm{~W} \\
\text { JEFFERSON }\end{array}$ & $\begin{array}{l}\text { BDYGNT } \\
\text { BEDG }\end{array}$ & SOUTH BENE & 46601 & 441463 & 8626528 & $\begin{array}{l}\text { MRKKEN } \\
\text { SZMUEZINSKR }\end{array}$ & $(219) 27788515$ & 107,789 & . & 58.3 & 30 & 5 & SAINT JOSEPA \\
\hline $\begin{array}{l}\text { SOUTH DEARBORN } \\
\text { RSD }\end{array}$ & $\begin{array}{l}\text { SOUTH DEARBORN } \\
\text { R.S.D. }\end{array}$ & $\begin{array}{l}370 \text { WEST EADS } \\
\text { PARKWAY } \\
\end{array}$ & & LAWRENCEBURG & 47205 & 3905390 & -8451500 & \begin{tabular}{|l|} 
MR. DENNIS \\
FEICHTNER \\
MR. JERRYYLBBY
\end{tabular} & (812) 537-0457 & 二 & & 3.5 & 50 & 50 & DEARBORN \\
\hline \begin{tabular}{|l|} 
SOUTH HENRY RSD \\
SOUTH WHITLEY
\end{tabular} & \begin{tabular}{|l|} 
SOUTH HENRY RSD \\
SOUTH WHITLEY
\end{tabular} & $\frac{\text { P.O. BOX } 147}{118 \text { E. FRONT }}$ & & LEWISVILLE, & 47352 & 3948157 & -8521203 & \begin{tabular}{|l|} 
MR. JERRY LIBBY, \\
SUPT. \\
MR. THOMAS \\
\end{tabular} & (765) $332-2828$ & - & & 0.23 & 100 & & HENRY \\
\hline & $\begin{array}{l}\text { MUNICIPAL STP } \\
\text { SPEEDWAY }\end{array}$ & \begin{tabular}{|l|}
118 E. FRONT \\
STREET \\
1450 NORTAT
\end{tabular} & P.O. BOX 372 & SOUTH WHITLEY & 46787 & $\begin{array}{l}4104476 \\
306\end{array}$ & -8537437 & $\begin{array}{l}\text { RUDD, PRES. } \\
\text { MRR NORMANA }\end{array}$ & (219) $723-4020$ & 1,782 & \pm & 0.45 & 40 & 21 & WHITLEY \\
\hline SPEEDWAY WWIP & MUNICIPAL STP & LYNDHERST DR & 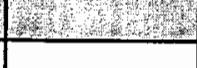 & SPEEDWAY & 46224 & 394650 & 863530 & BERRY & $(317) 248-1446$ & 12,881 & $\neq$ & 7.5 & 85 & 25 & MARION \\
\hline $\begin{array}{l}\text { SPENCER } \\
\text { MUNICIPAL WWTP } \\
\end{array}$ & SPENCER WWTP & $\begin{array}{l}90 \text { NORTH } \\
\text { WEST STREET } \\
\end{array}$ & & SPENCER & 47460 & 3917006 & -8646142 & $\begin{array}{l}\text { MRS. SHELLEY } \\
\text { EDWARDS }\end{array}$ & $(812) 829-2195$ & 2,508 & & 0.5 & 100 & 35 & OWEN \\
\hline $\begin{array}{l}\text { ST. LEON } \\
\text { MUNICIPAL STP } \\
\end{array}$ & $\begin{array}{l}\text { ST. LEON } \\
\text { MUNICIPAL STP } \\
\text { STAUNTON }\end{array}$ & $\begin{array}{l}059 \text { STATE } \\
\text { HWY } 46\end{array}$ & W. COLUMBUS & WEST HARRISON & 47060 & 3916437 & -8452361 & $\begin{array}{l}\text { MR. RODNEY W. } \\
\text { LAKE }\end{array}$ & $(812) 637-2150$ & 387 & & 0.3 & & & DEARBORN \\
\hline $\begin{array}{l}\text { SULLIVAN WWTP } \\
\text { SUMMIT SPRINGS }\end{array}$ & $\begin{array}{l}\text { SULLIVAN } \\
\text { MUNICIPAL STP } \\
\text { SUMMIT SPRINGS }\end{array}$ & P.O. BOX 307 & & SULLIVAN & 47882 & 3906000 & -8725000 & \begin{tabular}{|l} 
MR. TIM MEIER \\
MR. MALCOM J.
\end{tabular} & (812) 268-5483 & 4,617 & & 0.46 & 70 & & SULLIVAN \\
\hline $\begin{array}{l}\text { SUMMIT SPRINGS } \\
\text { RSD } \\
\end{array}$ & $\begin{array}{l}\text { SUMMIT SPRINGS } \\
\text { REG. WASTE DIST } \\
\end{array}$ & P.O. BOX 63 & & MT. SUMMIT & 47361 & 4000328 & -8525389 & $\begin{array}{l}\text { MR. MALCOM J. } \\
\text { FADELY, PRES. } \\
\text { MR. THOMAS F. }\end{array}$ & (765) 836-4349 & - & & 0.18 & 100 & 25 & HENRY \\
\hline $\begin{array}{l}\text { SUMMITVILLE } \\
\text { SEWAGE SYS } \\
\end{array}$ & $\begin{array}{l}\text { SUMMITVILLE } \\
\text { MUNICIPAL STP } \\
\text { SUNMAN }\end{array}$ & P.O. BOX 368 & & SUMMITVILLE & 46070 & 4019078 & -8539522 & $\begin{array}{l}\text { MR. THOMAS F. } \\
\text { MARSHALL } \\
\end{array}$ & (765) 536-4353 & 1,090 & * & 0.11 & 80 & & MADISON \\
\hline SUNMAN WWTP & MUNICIPAL STP & P.O. BOX 147 & & SUNMAN & 47041 & 3913428 & -8506329 & MR. RON ROACH & $(812) 623-3720$ & 805 & & 0.225 & 100 & 70 & RIPLEY \\
\hline$\frac{\text { SWAYZEE WWTP }}{\text { SWITZ CITY }}$ & $\begin{array}{l}\text { SWAYZEE } \\
\text { MUNICIPAL STP } \\
\text { SWITZ CITY }\end{array}$ & P. O. BOX 85 & & SWAYZEE & 46986 & 4030451 & -8549496 & $\begin{array}{l}\text { MR. DEREK } \\
\text { PATTERSON, } \\
\text { PRES. } \\
\end{array}$ & (765) 922-7880 & 1,011 & & 0.18 & & & GRANT \\
\hline $\begin{array}{l}\text { SWIIZ CIIY } \\
\text { MUNICIPAL STP }\end{array}$ & $\begin{array}{l}\text { SWITZ CITY } \\
\text { MUNICIPAL STP }\end{array}$ & P.O. BOX 191 & & SWITZ CITY & 47465 & 3902454 & -8702345 & MR. DAVID FISH & (812) 847-6717 & 311 & & 0.036 & & & GREENE \\
\hline
\end{tabular}


Directory of Indiana POTWs Compiled from EPAIDEM Files

Compilation Date: May, 2001

Indiana Clean Manufacturing Technology and Safe Materials Institute

Purdue University

West Lafayette, Indiana

(Updated 1/13/04)

\begin{tabular}{|c|c|c|c|c|c|c|c|c|c|c|c|c|c|c|c|}
\hline Facility Name & Mailing Name & Mailing Streel 1 & Mailing Street 2 & Mailing City & ZIP & Latitude & Longitude & $\begin{array}{l}\text { Official } \\
\text { Representative }\end{array}$ & $\begin{array}{l}\text { Official } \\
\text { Representative } \\
\text { Telephone } \\
\text { Number } \\
\end{array}$ & $\frac{P o p}{(2000)}$ & $\underline{C S}$ & Q Design & $\frac{\%}{\text { San }}$ & $\%$ Ind & County \\
\hline SYRACUSE WWTP & \begin{tabular}{|l} 
SYRACUSE \\
MUNICIPAL STP
\end{tabular} & \begin{tabular}{|l}
310 NORTH \\
HUNTINGTON \\
\end{tabular} & & SYRACUSE & 46567 & 4125369 & -8545328 & $\begin{array}{l}\text { CLINTON } \\
\text { HOUSEWORTH, } \\
\text { UTIL. DIR. } \\
\end{array}$ & (219) 457-3229 & 3,038 & & 1.05 & 100 & 10 & KOSCIUSKO \\
\hline TELL CITY WWTP & $\begin{array}{l}\text { TELL CITY } \\
\text { MUNICIPAL WWTP }\end{array}$ & P.O. BOX 217 & & TELL CITY & 47586 & 3757140 & -8646330 & $\begin{array}{l}\text { MR. PATRICK } \\
\text { BEAMON } \\
\end{array}$ & $(812) 547-4151$ & 7,845 & * & 2.06 & & & PERRY \\
\hline TENNYSON WWTP & TENNYSON WWTP & $\begin{array}{l}\text { TOWN BOARD } \\
\text { OF TENNYSON }\end{array}$ & P.O. BOX 116 & TENNYSON & 47637 & 3804500 & -8707000 & MR. DON PHILLIPS & $(812) 567-8816$ & 290 & & 0.045 & 100 & & WARRICK \\
\hline $\begin{array}{l}\text { TERRE HAUTE } \\
\text { WWIP }\end{array}$ & $\begin{array}{l}\text { WERRE TAUTE } \\
W W P\end{array}$ & (3) & $\begin{array}{l}17 \text { HARDING } \\
\text { AVENUE }\end{array}$ & MERRE HAUTE & 4807 & 3925410 & 8725510 & 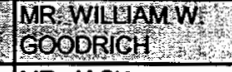 & $(812) 2326564$ & 59,614 & 雨 & 24 & 40 & 10 & UIGO \\
\hline $\begin{array}{l}\text { THORNTOWN } \\
\text { UTILITIES } \\
\end{array}$ & $\begin{array}{l}\text { THORNTOWN } \\
\text { UTILITIES } \\
\end{array}$ & $\begin{array}{l}109 \text { WEST MAIN } \\
\text { STREET }\end{array}$ & & THORNTOWN & 46071 & 4008226 & -8636433 & $\begin{array}{l}\text { MR. JACK } \\
\text { HUTCHENS }\end{array}$ & (765) 436-2627 & 1,562 & & 0.16 & 100 & & BOONE \\
\hline $\begin{array}{l}\text { TIPTON MUNICIPAL } \\
\text { STP } \\
\end{array}$ & $\begin{array}{l}\text { TIPTON MUNICIPAL } \\
\text { STP }\end{array}$ & $\begin{array}{l}113 \text { COURT } \\
\text { STREET }\end{array}$ & P.O. BOX 288 & TIPTON & 46072 & 4016533 & -8601370 & $\begin{array}{l}\text { MR. HENRY } \\
\text { HOELSCHER }\end{array}$ & (765) 675-2234 & 5,251 & * & 2 & 20 & 15 & ITIPTON \\
\hline $\begin{array}{l}\text { TOPEKA MUNICIPAL } \\
\text { WWTP }\end{array}$ & $\begin{array}{l}\text { TOPEKA MUNICIPAL } \\
\text { STP }\end{array}$ & P. O. BOX 127 & \begin{tabular}{|l|}
101 SOUTH \\
MAIN STREET
\end{tabular} & TOPEKA & 46571 & 4132180 & -8532240 & $\begin{array}{l}\text { MR. LARRY } \\
\text { SCHROCK }\end{array}$ & (219) 593-2300 & 1,159 & & 0.15 & 100 & & LAGRANGE \\
\hline $\begin{array}{l}\text { TRAFALGAR } \\
\text { MUNICIPAL WWTP }\end{array}$ & $\begin{array}{l}\text { TRAFALGAR } \\
\text { MUNICIPAL STP } \\
\end{array}$ & P.O. BOX 57 & & TRAFALGAR & 46181 & 3925221 & -8609069 & $\begin{array}{l}\text { KENNETH } \\
\text { MATTHEWS, } \\
\text { PRES. }\end{array}$ & (317) 878-4591 & 798 & & 0.11 & 100 & & JOHNSON \\
\hline TRI LAKES RSD & TRI LAKES RSD & $\begin{array}{l}\text { R.R. \#8, } \\
\text { WILCHERN RD }\end{array}$ & P.O. BOX 667 & COLUMBIA CITY & 46725 & 4113448 & -8525440 & $\begin{array}{l}\text { MR. GEORGE } \\
\text { BRUCE, PRES. }\end{array}$ & (218) 248-3112 & - & & 0.188 & 100 & & WHITLEY \\
\hline $\begin{array}{l}\text { TURKEY CREEK } \\
\text { RSD } \\
\end{array}$ & $\begin{array}{l}\text { TURKEY CREEK } \\
\text { REGIONAL SWR. D. }\end{array}$ & 4852 N. 1200 W. & & CROMWELL & 46732 & 4125194 & -8539121 & $\begin{array}{l}\text { MR. DALE ALLEN, } \\
\text { PRES. }\end{array}$ & (219) 856-4341 & - & & 0.37 & 100 & & KOSCIUSKO \\
\hline TURKEY RUN RSD & TURKEY RUN RSD & P.O. BO 288 & & MARSHALL & 47859 & 399120 & -871832 & $\begin{array}{l}\text { MR. KEVIN } \\
\text { STEWART } \\
\end{array}$ & & - & & 0.17 & & & PARKE \\
\hline UNION CITY WWTP & $\begin{array}{l}\text { UNION CITY } \\
\text { MUNICIPAL STP }\end{array}$ & $\begin{array}{l}115 \text { NORTH } \\
\text { COLUMBIA ST }\end{array}$ & & UNION CITY & 47390 & 4012410 & -8449251 & $\begin{array}{l}\text { MR. RONALD S. } \\
\text { THOMPSON } \\
\end{array}$ & (765) 964-5544 & 3,622 & & 1.5 & & 10 & RANDOLPH \\
\hline $\begin{array}{l}\text { UNIONDALE } \\
\text { MUNICIPAL STP } \\
\end{array}$ & $\begin{array}{l}\text { UNIONDALE } \\
\text { MUNICIPAL STP }\end{array}$ & $\begin{array}{l}\text { TOWN OF } \\
\text { UNIONDALE } \\
\end{array}$ & P.O. BOX 125 & UNIONDALE & 46791 & 4049144 & -8514291 & $\begin{array}{l}\text { MR. RON SLIGER, } \\
\text { PRES. }\end{array}$ & $(219) 543-2266$ & 277 & & 0.0223 & & & WELLS \\
\hline $\begin{array}{l}\text { UPLAND MUNICIPAL } \\
\text { WWTP }\end{array}$ & $\begin{array}{l}\text { UPLAND MUNICIPAL } \\
\text { WWTP }\end{array}$ & P.O. BOX 428 & & UPLAND & 46989 & 4027484 & -8529158 & $\begin{array}{l}\text { MR. FRANK LEIST, } \\
\text { CERT. OPER. }\end{array}$ & (765) 998-7287 & 3,803 & & 0.7 & 100 & 10 & GRANT \\
\hline $\begin{array}{l}\text { VAN BUREN } \\
\text { MUNICIPAL WWTP } \\
\end{array}$ & $\begin{array}{l}\text { VAN BUREN } \\
\text { MUNICIPAL WWTP }\end{array}$ & P. O. BOX 392 & $\begin{array}{l}201 \text { NORTH } \\
\text { FIRST STREET } \\
\end{array}$ & VAN BUREN & 46991 & 4036394 & -8529526 & $\begin{array}{l}\text { MR. TONY MANRY, } \\
\text { PRES. }\end{array}$ & (765) 934-4665 & 935 & & 0.14 & 100 & & GRANT \\
\hline $\begin{array}{l}\text { VEEDERSBURG } \\
\text { MUNICIPAL WWTP } \\
\end{array}$ & $\begin{array}{l}\text { VEEDERSBURG } \\
\text { MUNICIPAL STP }\end{array}$ & $\begin{array}{l}100 \text { S. MAIN } \\
\text { STREET }\end{array}$ & & VEEDERSBURG & 47987 & 4005502 & -8715498 & $\begin{array}{l}\text { MR. CARL } \\
\text { HOAGLAND, } \\
\text { PRES. }\end{array}$ & (765) 294-2728 & 2,299 & * & 0.3 & 75 & & FOUNTAIN \\
\hline VERSAILLES WWTP & \begin{tabular}{|l} 
VERSAILLES \\
SEWER WORKS \#2
\end{tabular} & \begin{tabular}{|l} 
TOWN OF \\
VERSAILLES
\end{tabular} & P.O.BOX 436 & VERSAILLES & 47042 & 3902585 & -8516248 & $\begin{array}{l}\text { MR. KEVIN } \\
\text { HENSLEY }\end{array}$ & (812) 689-5130 & 1,784 & & 0.25 & 100 & & RIPLEY \\
\hline VEVAY WWTP & $\begin{array}{l}\text { VEVAY MUNICIPAL } \\
\text { STP }\end{array}$ & P.O. BOX 52 & $\begin{array}{l}210 \text { FERRY } \\
\text { STREET }\end{array}$ & VEVAY & 47043 & 3844468 & -8504373 & $\begin{array}{l}\text { MR. TERRY } \\
\text { BINDLEY }\end{array}$ & $(812) 427-2472$ & 1,735 & & 0.4 & 100 & & SWITZERLAND \\
\hline UNCENNESWWTT & $\begin{array}{l}\text { VINCENANES } \\
\text { MuUN NGIPAL STP }\end{array}$ & $P O B O \times 233$ & $\begin{array}{l}1118 \text { RVER } \\
\text { ROAQ }\end{array}$ & NNGENNES & 47591 & 3840346 & -8732307 & $\begin{array}{l}\text { MR TOQDDD } \\
\text { CHME }\end{array}$ & $(812) \& 865041$ & $88 ; 01$ & & 456 & 95 & & kNox \\
\hline WABASH WWIP & WABASH & $\begin{array}{l}202 \text { SOUTH } \\
\text { WABASH ST }\end{array}$ & 3 & WABASH & 46992 & 4047316 & 8549318 & MR RICK PRICE & $(219) 563-2941$ & 11,743 & & 6 & 30 & 25 & WABASH \\
\hline
\end{tabular}


Directory of Indiana POTWs Compiled from EPAIDEM Files

Compilation Date: May, 2001

Indiana Clean Manufacturing Technology and Safe Materials Institute Purdue University

West Lafayette, Indiana (Updated 1/13/04)

\begin{tabular}{|c|c|c|c|c|c|c|c|c|c|c|c|c|c|c|c|}
\hline Facility Name & Mailing Name & Mailing Street 1 & Mailing Street 2 & Mailing City & \begin{tabular}{|l}
$\frac{Z P}{P}$ \\
Code
\end{tabular} & Latitude & Longitude & $\begin{array}{l}\text { Official } \\
\text { Representative }\end{array}$ & \begin{tabular}{|l} 
Official \\
Representative \\
Telephone \\
Number \\
\end{tabular} & $\frac{\text { Pop }}{(2000)}$ & $\underline{c s}$ & Q Design & $\frac{\%}{\operatorname{san}}$ & $\%$ ind & County \\
\hline WAKARUSA WWTP & $\begin{array}{l}\text { WAKARUSA } \\
\text { MUNICIPAL STP }\end{array}$ & P. O. BOX 474 & & WAKARUSA & 46573 & 4132000 & -8601120 & $\begin{array}{l}\text { MR. DOUGLAS D. } \\
\text { PURDUE }\end{array}$ & (219) 862-4632 & 1,618 & * & 0.49 & & 30 & ELKHART \\
\hline WALDRON CD & WALDRON CD & P. O. BOX 242 & & WALDRON & 46182 & 3927358 & -8540385 & $\begin{array}{l}\text { MR. RONALD } \\
\text { FUCHS }\end{array}$ & (765) 525-9696 & 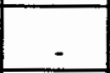 & & 0.12 & & & AELBY \\
\hline $\begin{array}{l}\text { WALKERTON } \\
\text { WWTP }\end{array}$ & $\begin{array}{l}\text { WALKERTON } \\
\text { MUNICIPAL STP }\end{array}$ & $\begin{array}{l}510 \text { ROOSEVELT } \\
\text { RD }\end{array}$ & & WALKERTON & 46574 & 4128189 & -8629133 & MR. JEFF ZEHNER & |(219) 586-3796 & 2,274 & & 0.364 & 0.3 & 2 & SAINT \\
\hline WALTON WWTP & $\begin{array}{l}\text { WALTON } \\
\text { MUNICIPAL STP }\end{array}$ & P.O. BOX 322 & $\begin{array}{l}100 \text { SOUTH } \\
\text { DEPOT }\end{array}$ & WALTON & 46994 & 4039480 & -8614300 & $\begin{array}{l}\text { MR. JOHN DAVID } \\
\text { RUSH }\end{array}$ & (219) 626-2941 & 1,069 & & 0.15 & 100 & & CASS \\
\hline WANATAH WWTP & $\begin{array}{l}\text { WANATAH } \\
\text { MUNICIPAL WWTP }\end{array}$ & P.O. BOX 185 & & WANATAH & 46390 & 4125102 & -8654214 & $\begin{array}{l}\text { MR. CHARLES A. } \\
\text { MACK }\end{array}$ & (219) $733-2340$ & 1,013 & & 0.078 & & & LA PORTE \\
\hline WARREN WWTP & $\begin{array}{l}\text { WARREN } \\
\text { MUNICIPAL STP }\end{array}$ & P. $0.80 \times 477$ & & WARREN & 46792 & 4041036 & -8525518 & $\begin{array}{l}\text { MR. LEE } \\
\text { POULSON }\end{array}$ & (219) 875-3424 & 1,272 & * & 0.25 & 30 & 10 & HUNTINGTON \\
\hline WARSAW wWTP & WARSAW & POB Bex 557 & $\begin{array}{l}794 \text { WEST } \\
\text { GENTER ST }\end{array}$ & WARSAW & 46589 & 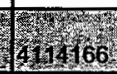 & 8552083 & MR DAYDVAN & $(219) 372-9563$ & 12,415 & the & 4 & 60 & 50 & KOSCIUSKO \\
\hline $\begin{array}{l}\text { WASHINGTON } \\
\text { MUNICIRAL STP }\end{array}$ & $\begin{array}{l}\text { WASHINGTON } \\
\text { MUNICIPAI STIP }\end{array}$ & $\begin{array}{l}\text { 101 NE THIRD } \\
\text { STREET }\end{array}$ & 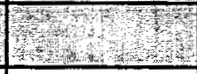 & WASAINGTON & 47504 & 3839104 & 8712180 & $\begin{array}{l}\text { BON } 7 \text { HOMAS } \\
\text { BASMER }\end{array}$ & $(812) 254=2730$ & 11,380 & it & 1.9 & 82 & 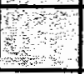 & AVIE \\
\hline $\begin{array}{l}\text { WASHINGTON } \\
\text { TOWNSHIP RSD } \\
\end{array}$ & $\begin{array}{l}\text { WASHINGTON } \\
\text { TOWNSHIP RSD } \\
\end{array}$ & P.0. BOX 121 & & NEW WASHINGTON & 47162 & 3833290 & -8534099 & $\begin{array}{l}\text { MR. RON REPPE, } \\
\text { PRES. }\end{array}$ & (812) 293-3352 & $=$ & & 0.09 & 100 & & CLARK \\
\hline $\begin{array}{l}\begin{array}{l}\text { WATERLOOO } \\
\text { MUNICIPAL STP }\end{array} \\
\end{array}$ & $\begin{array}{l}\text { WATERLOO } \\
\text { MUNICIPAL STP }\end{array}$ & P.O. BOX 96 & & WATERLOO & 46793 & 4125493 & -8500374 & $\begin{array}{l}\text { MS. LYNN W. } \\
\text { CARPER }\end{array}$ & (219) 837-7428 & 2,200 & \pm & 24 & 40 & 75 & $\mathrm{KA}$ \\
\hline $\begin{array}{l}\text { SWN } \\
\text { LLWWTP }\end{array}$ & \begin{tabular}{|l} 
WAYNETOOWN \\
MUNICIPAL STP
\end{tabular} & P. O. BOX 215 & $\begin{array}{l}106 \text { WEST } \\
\text { WASHINGTON }\end{array}$ & WAYNETOWN & 47990 & 4005180 & -8704000 & $\begin{array}{l}\text { MR. GREGORY } \\
\text { GAYLER }\end{array}$ & (765) 234-2154 & 909 & & 0.1 & 100 & & MONTE \\
\hline $\begin{array}{l}\begin{array}{l}\text { WEST COLLEGE } \\
\text { CORNER POTW }\end{array} \\
\end{array}$ & $\begin{array}{l}\text { WEST COLLEGE } \\
\text { CORNER STP }\end{array}$ & P.O. B & & $\begin{array}{l}\text { W COLLEGE } \\
\text { CORNER }\end{array}$ & 47003 & 3933326 & -8448583 & $\begin{array}{l}\text { MR. RONALD } \\
\text { MIDDLETON }\end{array}$ & $(317) 647-5224$ & 634 & & 24 & 100 & & JUNION \\
\hline $\begin{array}{l}\text { WEST EREAYETTE } \\
\text { POTW }\end{array}$ & $\begin{array}{l}\text { WEST WAFAYETTE } \\
\text { MUNTCIPALSTP }\end{array}$ & $\begin{array}{l}\text { 609 WEST } \\
\text { NAVAJO SE }\end{array}$ & 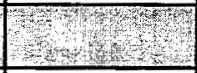 & WEST LAFAYET & 47906 & 402504 & 8651162 & HON, JAN MUISLS & $(765): 743 \cdot 2302$ & 28.718 & it & 78 & and & and & TIPPE \\
\hline $\begin{array}{l}\text { WEST LEBANON } \\
\text { TOWN OF } \\
\end{array}$ & WES & P. O. BOX 201 & $\begin{array}{l}201 \text { HIGH } \\
\text { STREET }\end{array}$ & WEST LEBANON & 47991 & 4016200 & -8723000 & $\begin{array}{l}\text { MIDDLETON J. } \\
\text { BROOKSHIRE }\end{array}$ & (765) 893-4014 & 793 & & 0.078 & 100 & & WARREN \\
\hline $\begin{array}{l}\text { WESTTERRE } \\
\text { HAUTE SANITARY }\end{array}$ & $\begin{array}{l}\text { WESTTERRE } \\
\text { HAUTE SANITARY }\end{array}$ & $\begin{array}{l}\text { SEWER } \\
\text { DEPARTMENT }\end{array}$ & $\begin{array}{l}\text { 525.WEST } \\
\text { ATCLEFAVE }\end{array}$ & WEST TERRE & 47885 & 3927262 & - 26511 & $\begin{array}{l}M R \text { JERRY } \\
\angle \mathrm{LETGABEL}\end{array}$ & $(812) 533,2909$ & a & & onsts & & & - \\
\hline $\begin{array}{l}\text { WES } \\
\text { MUUNic }\end{array}$ & WESTHLCL & $\begin{array}{l}\text { WESTE } \\
\text { TOWNA: }\end{array}$ & SBOEAST & WESTFELE & 46074 & 4quiziz: & 80 & $\begin{array}{l}\text { MA MCHAE } \\
M C D O N A D \\
\text { RES }\end{array}$ & & 9,293 & & 1 & & & HAMloton \\
\hline $\begin{array}{l}\text { WESTPORT } \\
\text { MUNICIPAL WWTP } \\
\end{array}$ & $\begin{array}{l}\text { WESTF } \\
\text { MUNIC }\end{array}$ & P.O. BOX 579 & & WESTPORT & 47283 & 3909454 & -8534505 & $\begin{array}{l}\text { MR. MARK A. } \\
\text { TAYLOR } \\
\end{array}$ & (812) 591-3500 & 1,515 & & 0.17 & 100 & & DECATUR \\
\hline VWTP & $\begin{array}{l}\text { WESTVILLE } \\
\text { MUNICIPAL STP }\end{array}$ & P.O. BOX 275 & & WESTVILLE & 46391 & 4132300 & -8653300 & MR. BART FRANK & $(219) 785-2413$ & 2,116 & & 0.35 & 100 & 10 & LA PORTE \\
\hline ELD & $\begin{array}{l}\text { TOWN OF } \\
\text { WHEATFIELD }\end{array}$ & SEWER WORKS & P.O. BOX 9 & WHEATFIELD & 46392 & 4111300 & -8702450 & AMAN & (219) 956-3365 & 772 & & 0.077 & & & JASPER \\
\hline $\begin{array}{l}\text { WHIIFE } \\
\text { MUUNIC }\end{array}$ & WHITE & $500: 50$ & & WHITELAND & 46184 & 3932351 & 8605223 & $\begin{array}{l}\text { MR:DANCSIKOS: } \\
\text { PRES U }\end{array}$ & $1(317) 535767$ & 3958 & & 0.42 & 100 & & WOHNSON \\
\hline $\begin{array}{l}\text { WHITESTOWN } \\
\text { MUNICIPAL WWTP }\end{array}$ & $\begin{array}{l}\text { WHITESTOWN } \\
\text { WWTP }\end{array}$ & P. O. BOX 25 & & WHITESTOWN & 46075 & 3959398 & -8620279 & $\begin{array}{l}\text { MR. MARK } \\
\text { BENNINGTON }\end{array}$ & (317) 501-9866 & 471 & & 0.08 & 100 & & BOONE \\
\hline
\end{tabular}


Directory of Indiana POTWs Compiled from EPAIDEM Files

Compilation Date: May, 2001

Indiana Clean Manufacturing Technology and Safe Materials Institute

Purdue University

West Lafayette, Indiana

(Updated 1/13/04)

\begin{tabular}{|c|c|c|c|c|c|c|c|c|c|c|c|c|c|c|c|}
\hline Facility Name & Mailing Name & Mailing Street 1 & Mailing Streel 2 & Mailing City & $\frac{\text { Zip }}{\text { Code }}$ & Latitude & Longitude & $\begin{array}{l}\text { Official } \\
\text { Representative }\end{array}$ & $\begin{array}{l}\text { Official } \\
\text { Representative } \\
\text { Telephone } \\
\text { Number } \\
\end{array}$ & $\frac{P 0 p}{(2000)}$ & $\underline{\mathrm{CS}}$ & Q Design & $\underline{\%}$ & $\%$ ind & County \\
\hline $\begin{array}{l}\text { WILLIAMSPORT } \\
\text { MUNICIPAL WWTP }\end{array}$ & $\begin{array}{l}\text { WILLIAMSPORT } \\
\text { MUNICIPAL STP }\end{array}$ & $\begin{array}{l}29 \text { NORTH } \\
\text { MONROE } \\
\end{array}$ & & WILLIAMSPORT & 47993 & 4017177 & -8717010 & $\begin{array}{l}\text { MR. MARK } \\
\text { HUTSON }\end{array}$ & (765) 762-3570 & 1,935 & & 0.22 & 100 & $>1$ & WARREN \\
\hline $\begin{array}{l}\text { WINAMAC } \\
\text { MUNICIPAL WWTP }\end{array}$ & \begin{tabular}{|l} 
WINAMAC \\
MUNICIPAL STP
\end{tabular} & $\begin{array}{l}120 \text { WEST MAIN } \\
\text { STREET }\end{array}$ & & WINAMAC & 46996 & 4103060 & -8636240 & $\begin{array}{l}\text { MR. BRADLEY } \\
\text { ZELLERS }\end{array}$ & (219) 946-3494 & 2,418 & * & 0.434 & & & PULASKI \\
\hline $\begin{array}{l}\text { WINCHESTER } \\
\text { WWTP } \\
\end{array}$ & \begin{tabular}{|l} 
WINCHESTER \\
MUNICIPAL_STP \\
\end{tabular} & \begin{tabular}{|l}
13 EAST \\
WASHINGTON \\
\end{tabular} & & WINCHESTER & 47394 & 4011084 & -8459114 & $\begin{array}{l}\text { MR. GARY A } \\
\text { ANDERSON }\end{array}$ & (765) 584-1331 & 5,037 & & 1.324 & 95 & 10 & RANDOLPH \\
\hline $\begin{array}{l}\text { WINDFALL } \\
\text { MUNICIPAL WWTP }\end{array}$ & $\begin{array}{l}\text { WINDFALL CITY } \\
\text { MUNICIPAL STP } \\
\end{array}$ & P.O. BOX 486 & & WINDFALL CITY & 46076 & 4021211 & -8557073 & $\begin{array}{l}\text { MR. TERRY } \\
\text { COOPER, SUPT. }\end{array}$ & (765) 945-8118 & 712 & & 0.13 & 100 & & TIPTON \\
\hline $\begin{array}{l}\text { WINGATE } \\
\text { MUNICIPAL WWTP }\end{array}$ & $\begin{array}{l}\text { WINGATE } \\
\text { MUNICIPAL STP }\end{array}$ & P. O. BOX 253 & & WINGATE & 47994 & 4010200 & -8704200 & $\begin{array}{l}\text { MR. MORRIS } \\
\text { MCCULLOCH, } \\
\text { PRES. }\end{array}$ & (765) 275-2407 & 299 & & 0.035 & 100 & & MONTGOMERY \\
\hline $\begin{array}{l}\text { WINSLOW } \\
\text { MUNICIPAL WWTP }\end{array}$ & $\begin{array}{l}\text { WINSLOW } \\
\text { MUNICIPAL STP }\end{array}$ & P.O. BOX 69 & & WINSLOW & 47598 & 3823215 & -8713516 & $\begin{array}{l}\text { MR. DAVID A } \\
\text { TISDALE, PRES. }\end{array}$ & $(812) 789-2620$ & 881 & & 0.074 & & & PIKE \\
\hline $\begin{array}{l}\text { WOLCOTT } \\
\text { MUNICIPAL WWTP }\end{array}$ & $\begin{array}{l}\text { WOLCOTT } \\
\text { MUNICIPAL STP }\end{array}$ & P.O. BOX 38 & & WOLCOTT & 47995 & 4045266 & -8702058 & $\begin{array}{l}\text { MR. DENNIS } \\
\text { CRANDALL }\end{array}$ & $(765) 474-1193$ & 989 & & 0.2 & 100 & & WHITE \\
\hline $\begin{array}{l}\text { WOLCOTTVILLE } \\
\text { MUNICIPAL WWTP }\end{array}$ & $\begin{array}{l}\text { WOLCOTTVILLE } \\
\text { MUNICIPAL_STP }\end{array}$ & P.O. BOX 325 & \begin{tabular}{|l|}
104 WEST \\
RACE STREET
\end{tabular} & WOLCOTTVILLE & 46795 & 4131350 & -8522326 & $\begin{array}{l}\text { MR. MATT } \\
\text { JORDAN }\end{array}$ & (219) 854-3316 & 933 & & 0.25 & 100 & & LAGRANGE \\
\hline $\begin{array}{l}\text { WOODBURN } \\
\text { MUNICIPAL WWTP }\end{array}$ & $\begin{array}{l}\text { WOODBURN } \\
\text { MUNICIPAL STP }\end{array}$ & P. O. BOX 75 & & WOODBURN & 46797 & 4107589 & -8450207 & $\begin{array}{l}\text { MR. MICHAEL A. } \\
\text { MCCONNELL }\end{array}$ & (219) 632-5318 & 1,579 & & 0.15 & 100 & & ALLEN \\
\hline $\begin{array}{l}\text { WORTHINGTON } \\
\text { MUNICIPAL WWTP }\end{array}$ & $\begin{array}{l}\text { WORTHINGTON } \\
\text { MUNICIPAL STP }\end{array}$ & P.O. BOX 82 & $\begin{array}{l}20 \mathrm{~S} \\
\text { COMMERCIAL } \\
\text { ST., SUITE } 2 \\
\end{array}$ & WORTHINGTON & 47471 & 3905513 & -8658441 & $\begin{array}{l}\text { MR. JAMES F. } \\
\text { MARKET }\end{array}$ & $(812) 875-2641$ & 1,481 & & 0.16 & 100 & & GREENE \\
\hline YoRk owN ww & YORKTOWN & $\mathrm{POQOAS \textrm {B }}$ & $\begin{array}{l}720 \text { WEST } \\
\text { STMTH STREET }\end{array}$ & YORKTOWNN & 47396 & 4010262 & $\begin{array}{r}\because 53015 \\
015\end{array}$ & MR ALLENNEFE & $(765) 759698$ & 4785 & & 2 & 99 & 10 & \\
\hline $\begin{array}{l}\text { ZANESVILLE } \\
\text { MUNICIPLE STP } \\
\end{array}$ & $\begin{array}{l}\text { ZANESVILLE } \\
\text { MUNICIPAL STP }\end{array}$ & & & ZANESVILLE & 46799 & 409123 & -852852 & & & 602 & & 0.101 & & & WELLS \\
\hline 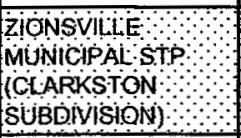 & 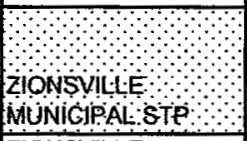 & TOWH HALI & 10 S ATHST & ZJONSVYLLE & 46077 & 39978 & 862873 & MROEN & $(317) 873-2332$ & 4,887 & & 005 & 100 & & BOONE: \\
\hline $\begin{array}{l}\text { ZIONSVILLE TOWN } \\
\text { OF }\end{array}$ & $\begin{array}{l}\text { ZIONSVILLE } \\
\text { MUNICIPAL STP } \\
\end{array}$ & $\begin{array}{l}\text { TOWN OF } \\
\text { ZIONSVILLE }\end{array}$ & $110 \mathrm{~S} .4 \mathrm{TH}$ ST & ZIONSVILLE & 46077 & 3956432 & -8616135 & $\begin{array}{l}\text { MR. DENNIS } \\
\text { MACKEY }\end{array}$ & $(317) 873-2332$ & 4,387 & & 0.95 & 100 & & BOONE \\
\hline & & & & & & & & & & & & & & & \\
\hline \multicolumn{16}{|c|}{ KEY } \\
\hline & & & & & & & & & & & & & & & \\
\hline 437) & \multicolumn{2}{|c|}{ MS4 with Combined Sewer POTW } & & & & & & & & & & & & & \\
\hline & & & & & & & & & & & & & & & \\
\hline$\cdots$ & \multicolumn{2}{|c|}{ MS4 without Combined Sewer POTW } & & & & & & & & & & & & & \\
\hline & & & & & & & & & & & & & & & \\
\hline & Non-MS4 POTWs & & & & & & & & & & & & & & \\
\hline
\end{tabular}


APPENDIX G 
State Maintained Highway Segments Discharging Storm Water to

Municipal Combined Sanitary/Storm Sewer Collection Systems

A Summary of 31 Responses from an August 12, 2003 Survey of Indiana's 106

Combined Sanitary/Storm Sewer POTWs

City

Fort Wayne

$\vec{a}$

Speedway

Oxford

\section{SR 55}

Tipton

\section{SR 28E}

Akron
SR 352

SR 352

SR $19 \mathrm{~S}$

SR 19 N

$\underline{\text { State Route }}$

SR 930

SR 930

SR 930

SR 14

SR 14

SR 19

SR 19 $\underline{\text { Local Name }}$

Clinton St.

Lafayette St. \& Spy Run Ave.

Coliseum Blvd. East

Coliseum Blvd. North

Lincoln Hwy.

\section{Michigan St. \\ McConnell St. \\ West Benton}

Jefferson St.

Main Street

Ash Street

West Rochester St.

East Rochester St.

N. Mishawaka

S. Mishawaka $\underline{\text { from }}$

Penn Ave.

Brook St.

Crescent Ave.

Vance Ave.

Coliseum Blvd. North

(@) Cloverleaf)

Wilson (on Michigan)

Michigan

Justus (on Benton)

Kentucky St. East

Jefferson St. South

Hill Street South

SR 19 \& SR 14 Junction SR 19 \& SR 14 Junction

SR 19 \& SR 14

SR 19 \& SR 14 to

McKinnie Ave.

Pettit Ave.

Glen Hurst Ave.

State Blvd.

Approx. Length (miles)

4.4

4.3

0.2

0.6

(士) Ft. Wayne RR

0.1

$\begin{array}{ll}\text { Benton } & 0.2 \\ \text { Benton } & 0.3 \\ \text { Fifth } & 0.1\end{array}$

900 E. Jefferson St.

1.1

Jackson St.

0.3

Jefferson St.

0.8

West Walnut

0.02

SR 14 turns N

0.1

2 block N on SR 19

0.02

1 block S on SR 19 


\begin{tabular}{|c|c|c|c|c|c|}
\hline City & $\underline{\text { State Route }}$ & Local Name & from & Appr & $\begin{array}{l}\text { rox. Length } \\
\text { (miles) }\end{array}$ \\
\hline \multirow[t]{2}{*}{ Richmond } & SR 227 & North J St. & US $27 \&$ SR 227 Junction & $\begin{array}{l}200^{\prime} \text { E US } 27 \& \\
\text { SR } 227 \text { Junction }\end{array}$ & 0.04 \\
\hline & US 27 & S. $9^{\text {th }} \&$ S. $8^{\text {th }}$ & South A St. & South L St. & 0.6 \\
\hline \multirow[t]{4}{*}{ LaPorte } & SR 4 & Monroe St. & Maple Ave. & Kingsbury Ave. & 2.0 \\
\hline & US 35 & Indiana Ave. & Maple Ave. & Kingsbury Ave. & 1.2 \\
\hline & SR 2 & Lincolnway \& J St. & K Street & Tyler St. & 0.8 \\
\hline & SR 2 & Lincolnway E & Detroit & Boyd Blvd. & 1.3 \\
\hline \multirow[t]{2}{*}{ Seymour } & SR 11 & North Broadway & $3^{\text {rd }} \mathrm{St}$ & Rock Sewer (catch basin) & 0.04 \\
\hline & SR 11 & North Broadway & $2^{\text {nd }} \mathrm{St}$ & Rock Sewer (catch basin) & 0.04 \\
\hline \multirow[t]{2}{*}{ Royal Center } & SR 35 & Chicago St. & High School & $700 \mathrm{~N}$ & 2.0 \\
\hline & SR 16 & Black Lane & Market St. & $600 \mathrm{~W}$ & 1.5 \\
\hline \multirow[t]{6}{*}{ Goshen } & US 33 & Main \& Lincolnway E & - & - & - \\
\hline & US 33 & Elkhart Rd. \& Pike St. & - & - & - \\
\hline & US 15 & $\begin{array}{l}\text { N. Main St. \& Pike \& } \\
\text { S. Main }\end{array}$ & $\mathrm{N}$ of overpass & Wilden Ave. & 0.3 \\
\hline & US 15 & N. Main St. \& Pike \& & & & \\
\hline & & S. Main & S of Pike St. & Westwood Dr. & 1.9 \\
\hline & SR 4 & E. Lincoln Ave. & Main St. E & City Limits & 1.6 \\
\hline \multirow[t]{2}{*}{ Washington } & SR 57 & $\mathrm{~N}$ is $5^{\text {th }} \mathrm{St} .-\mathrm{S}$ is $\mathrm{S}$ IN 57 & SR 57 \& Crestview Dr. S & SR 57 \& Highland Ave. & 2.5 \\
\hline & Bus Rt 50 & National Hwy. & Bus Rt $50 \& \mathrm{SW} 5^{\text {th }} \mathrm{E}$ & Bus Rt 50 \& SR 257 & 1.2 \\
\hline \multirow[t]{2}{*}{ Hartford City } & SR 3 & Walnut St. & Park Ave. & Ritter Rd. & 2.0 \\
\hline & SR 26 & Washington St. & Center Pike (CR $100 \mathrm{~W})$ & CR $075 \mathrm{E}$ & 1.8 \\
\hline
\end{tabular}




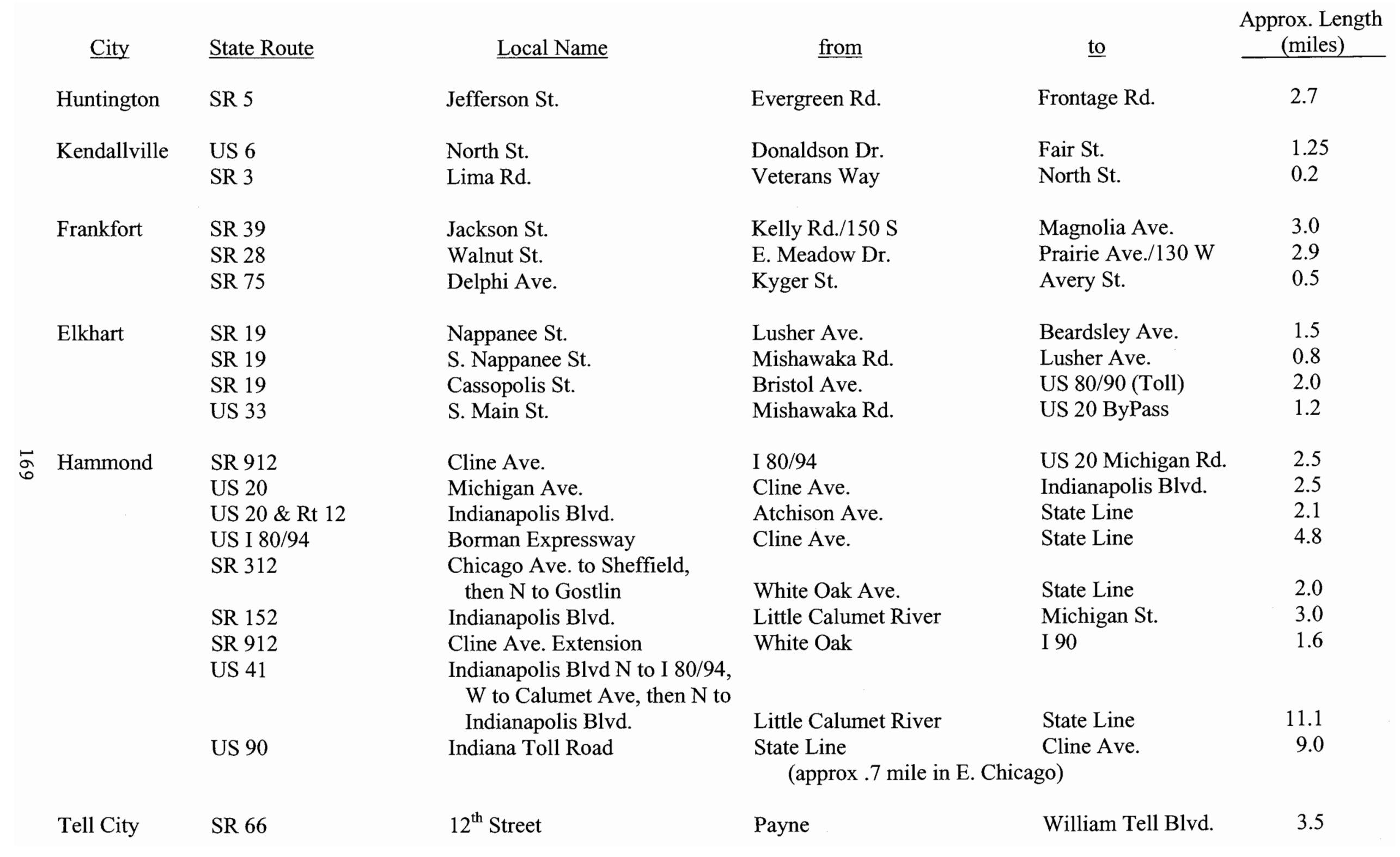


$\underline{\text { City }}$

$\underline{\text { State Route }}$

Ligonier

SR 5

US 6 \& US 33

Brownsburg SR 136

SR 267

Logansport

SR 17

SR 25

East Chicago US 41

US $12 \& 20$

ฑ

SR 912

New Haven

SR 930

I 469

I 469

Local Name

from

Cavin St., Lincolnway S, Northwood

US 6 \& SR 5 Intersection $700 \mathrm{E}$ of SR 5

Main St.

Green St.

$\mathrm{N} 3^{\text {rd }} \mathrm{St}$

S. Cicott St. \& Michigan Rd.

Indianapolis Blvd.

Columbus Dr.

Chicago Ave.

SR 267 (Green St.)

Twin St.

Market St.

S. Cicott St.

$151^{\text {st }}$ Street

Euclid

White Oak

Doyle Rd.

SR 930 to

Approx. Length

(miles)
SR 5 \& Johnson St. Inter. 1.8 Town Line Rd

Eastern Ave.

0.3

Washington Ave.

0.5

North Hillcrest

1.2

Chase Rd.

Columbus Drive

1.0

Hemlock

0.3

Parrish

Meyer Rd.

5.5

US 24

2.0

Total Miles $\quad 137.73$ 
APPENDIX H 
APPENDIX I 
The DNR Endangered, Threatened, Rare Species and High Quality Natural Communities (ETR)

Theme Name: $\quad$ indotetr.shp

Location: $\quad$..Land

Source: $\quad$ DNR

Extent: $\quad$ Statewide

Scale:

Type of Coverage: point

Source Date: $\quad 2000$

Projection: UTM

Datum: NAD83

Units: $\quad$ meters

\section{Data Layer Description:}

This database contains the Endangered, Threatened, Rare (ETR) Species and High Quality Natural Communities (ETR) of Indiana. Purdue University received this data in 2002. The database is not available except by special arrangement with the Indiana Department of Natural Resources, Natural Heritage Data Center (Contact Ronald P. Hellmich, 317-232-8059; Contact J. Osadczuk, Environment, Planning, and Engineering Division). The following are the field descriptions of the ETR database.

Indiana Natural Heritage Data Center: Field Definitions

Longitude: Longitude in decimal degrees

Latitude: $\quad$ Latitude in decimal degrees

Elcode: $\quad$ Heritage Species code

Eocode: Heritage species code plus 3 digit occurrence number

Type: $\quad$ Generic descriptor of species, i.e. bird, mammal, etc.

Sprot: $\quad$ State status

$\mathrm{SE}=$ state endangered. Any animal species whose prospects for survival or recruitment within the state are in immediate jeopardy and are in danger of disappearing from the state. This includes all species classified as endangered by the federal government which occur in Indiana. Plants known to occur currently on five ore fewer sites in the state are considered endangered.

$\mathrm{ST}=$ state threatened. Any animal species likely to become endangered within the foreseeable future. This includes all species classified as threatened by the federal government which occur in Indiana. Plants 
$\mathrm{GH}=$ historical

$\mathrm{GX}=$ extinct

Subrank

$\mathrm{T}=$ Taxonomic subdivision (e.g. subspecies_follows numerical ranks as with ranks above (T1, T2, etc.) for total rank like G3T3 etc.

Qualifiers

$?=$ inexact numeric rank

$\mathrm{Q}=$ questionable taxonomy

Srank: $\quad$ Heritage State Rank

$\mathrm{S} 1=$ critically imperiled in state (fewer than 5 occurrences)

$\mathrm{S} 2=$ imperiled in state (6-20 occurrences in state)

$\mathrm{S} 3$ = rare (typically 21-100 occurrences in state)

S3 = apparently secure (many occurrences)

S4 = apparently secure (many occurrences)

S5 $=$ demonstrably secure

$\mathrm{SA}=$ accidental in state

$\mathrm{SH}=$ of historical occurrence in state

$\mathrm{SX}=$ extirpated from state

$\mathrm{SU}=$ possibly imperiled, need more information

$\mathrm{SRE}=$ reintroduced in state

$\mathrm{SZ}=$ birds - migrant through state; or present in state but with no identifiable location

$\mathrm{SRF}=$ reported falsely in state

Qualifiers

$\mathrm{N}=$ nonbreeding status (generally for birds)

$\mathrm{B}=$ breeding status (generally for birds)

Trs1 Public land survey location Township Range Section information

Trs2 Public land survey location field 2

Trs3 Public land survey location field 3

Date date when occurrence documented

Misccommen Miscellaneous comments, used mostly for mussel species info on the condition occurrence documented as: live, fresh dead, weathered shells, subfossil

County1 County of occurrence

County2 County of occurrence field 2

Quadname USGS 7.5min quadrangle map of occurrence

Maname Conservation area of occurrence

Watershed USGS HUC code, 8-digit (computer takes off first digit, a zero)

Recreational Facilities with Waterbodies (Federal, state, county, municipal and township parks with waterbodies) 


$\begin{array}{ll} & \\ & \\ \text { Theme Name: } & \text { Recre_fedstcnmutw_lakep_river.shp } \\ \text { Location: } & \text {..Land } \\ \text { Source: } & \text { USGS } \\ \text { Extent: } & \text { Statewide } \\ \text { Scale: } & \\ \text { Type of Coverage: } & \text { point } \\ \text { Source Date: } & \text { 2001 } \\ \text { Projection: } & \text { UTM } \\ \text { Datum: } & \text { NAD83 } \\ \text { Units: } & \text { meters }\end{array}$

Data Layer Description:

This database consists of the Indiana recreation facilities inventory, a statewide point coverage of sites that offer facilities for public outdoor recreation. The point was usually recorded at the entrance or parking lot to the facility, which may be in a corner of the property. Purdue University received this data from DNR in 2001. Information for the Facilities inventory was collected iniatially by visiting each site, filling out a survey instrument for each site and collecting a GPS location data point. Information is updated as available using organizations master plan. In this database, based on the 'Areatype', only federal, state, county, municipal and township parks are chosen which have water bodies in them (fields 'Lakepond' and 'River') for swimming, fishing, boating etc. 
Exceptional Use and High Quality Waters

Theme Name: exceph2o.shp

Location: ...Water

Source:

DNR Division of Water

Extent:

Statewide

Scale: $\quad 1: 24,000$

Type of Coverage: line

Source Date:

Projection:

UTM

Datum:

NAD83

Units:

meters

\section{Data Layer Description:}

The line coverage contains exceptional use streams and high quality waters. Purdue University received this data from IDEM in 2002. The field 'Pname' gives the names of the waterbodies and the field 'Designatio' indicates the exceptional use waters and high quality waters as defined by IDEM's 327 IAC 2-1-2(3) and 327 IAC 2-1-11(b) rules. There are four High Quality Waters: Cedar Creek, Blue River, North Fork Wildcat, and South Fork Wildcat; and eleven Exceptional Use Waters: Big Pine Creek, Mud Pine Creek, Fall Creek, Indian Creek, Clifty Creek, Bear Creek, Rattlesnake Creek, tributary to Bear Creek in Fountain County, Blue River in Washington County to Ohio River, South Fork of Blue River, and Lost River. 
Scenic Rivers

Theme Name: $\quad$ scenic_rivers.shp

Location: ... $\quad$ WWater

Source: $\quad$ DNR outdoor recreation

Extent: $\quad$ Statewide

Scale: $\quad 1: 24,000$

Type of Coverage: line

Source Date: 1985

Projection: $\quad$ UTM

Datum: NAD83

Units: $\quad$ meters

Data Layer Description:

The line coverage contains rivers meeting natural or scenic classifications as defined by the Division of Outdoor Recreation in its 1985 Natural and Scenic Rivers reports. Purdue University received this data from DNR in ARC coverage in NAD27 format and later converted it to NAD83, shape file. The following rivers are the scenic rivers (given by field 'River_name') some of which are already designated and some of which are proposed (given by field 'Status'):

1. South Branch Elkhart River (Upper and lower)

2. Tippecanoe River (Upper and lower)

3. Cedar Creek (Upper and lower)

4. Wildcat Creek North Fork (Upper, middle, middle and lower)

5. Wildcat Creek South Fork

6. Wildcat Creek (Main)

7. Big Pine Creek

8. Sugar Creek (Upper, Middle M, Middle U, Middle L, lower)

9. Big Walnut Creek

10. Whitewater River (Upper and lower)

11. Sand Creek

12. Blue River (Upper and lower) 
Scenic Rivers: Designated

Theme Name: designdrivrs83.shp

Location:

...Water

Source:

DNR outdoor recreation

Extent:

Statewide

Scale:

Type of Coverage: line

Source Date:

Projection: UTM

Datum: NAD83

Units: meters

\section{Data Layer Description:}

This database contains a statewide line coverage of rivers which are designated in the State Natural and Scenic Rivers Program. It is a subset of the database of scenic rivers in the previous page ( $p: 50$ ). Purdue University received this data from DNR in 2001. The following rivers are considered designated which are given under the field 'River name':

1. Cedar Creek (Upper and lower)

2. Wildcat Creek North Fork (Upper, middle and lower)

3. Wildcat Creek South Fork

4. Wildcat Creek (Main)

5. Blue River (Upper and lower)

This database also includes the county names, quad names, mile length of the rivers, start and end locations of the rivers and many other attributes. 
Surface Intakes

Theme Name: surface_intakes.shp

Location: ..IWaterSupply

Source: $\quad$ Indiana State University for IDEM

Extent: $\quad$ Statewide

Scale: $\quad 1: 24,000$

Type of Coverage: polygon

Source Date: $\quad 1997-98$

Projection: UTM

Datum: $\quad$ NAD83

Units: $\quad$ meters

Data Layer Description:

This database contains 55 public drinking surface water supplies that were GPS located in $1997-8$ by Indiana State University for IDEM. The database contains information about system names, intake names, latitude and longitude data, comments about the intake, etc. 
APPENDIX J 
INDOT PRIORITY NO. 1

Rivers and Streams

\begin{tabular}{|c|c|c|c|c|}
\hline$\underline{\text { River }}$ & Significance & County & GIS Database & Segment \\
\hline Bear Creek & EUW & Fountain & EUS (WEM) & $\begin{array}{l}\text { C.R. } 250 \mathrm{~W} \text { to conflu- } \\
\text { ence with the Wabash }\end{array}$ \\
\hline $\begin{array}{l}\text { Bear Creek } \\
\text { Tributary }\end{array}$ & EUW & Fountain & EUS (IDEM) & $\begin{array}{l}\text { Within Portland Arch } \\
\text { Nature Preserve }\end{array}$ \\
\hline $\begin{array}{l}\text { Big Pine } \\
\text { Creek }\end{array}$ & EUW & Warren & EUS (IDEM) & $\begin{array}{l}\text { S.R. } 18 \text { to confluence } \\
\text { with Wabash River }\end{array}$ \\
\hline $\begin{array}{l}\text { Big Walnut } \\
\text { Creek }\end{array}$ & 7 & Putnam & N \& S (IDNR) & $\begin{array}{l}\text { Hendricks/Putnam Co. } \\
\text { Line to S.R. } 36\end{array}$ \\
\hline Blue River & HQW & $\begin{array}{l}\text { Crawford, } \\
\text { Harrison, } \\
\text { Washington }\end{array}$ & N \& S (IDNR) & $\begin{array}{l}\text { U.S. } 150 \text { in Fredericks- } \\
\text { burg to S.F. } 462\end{array}$ \\
\hline Blue River & EUW & Washington & EUS (IDEM) & $\begin{array}{l}\text { Confluence of West \& } \\
\text { Middle Forks of Ohio } \\
\text { River }\end{array}$ \\
\hline $\begin{array}{l}\text { Blue, South } \\
\text { Fork }\end{array}$ & EUW & Washington & EUS (IDEM) & $\begin{array}{l}\text { S.R. } 135 \text { to confluence } \\
\text { with Blue River }\end{array}$ \\
\hline Cedar Creek & HQW & $\begin{array}{l}\text { Allen, } \\
\text { DeKalb }\end{array}$ & N \& S (IDNR) & $\begin{array}{l}\text { DeKalb C.R. } 68 \text { to St. } \\
\text { Joseph River }\end{array}$ \\
\hline Clifty Creek & EUW & Montgomery & EUS (IDEM) & $\begin{array}{l}\text { Headwaters to conflu- } \\
\text { ence with Indian Creek }\end{array}$ \\
\hline $\begin{array}{l}\text { Elkhart River, } \\
\text { South Branch }\end{array}$ & 7 & Noble & N \& S (IDNR) & C.R. $100 \mathrm{~N}$ to U.S. 6 \\
\hline Fall Creek & EUW & Warren & EUS (IDEM) & $\begin{array}{l}\text { U.S. } 41 \text { to confluence } \\
\text { with Big Pine Creek }\end{array}$ \\
\hline Indian Creek & EUW & Montgomery & EUS (IDEM) & $\begin{array}{l}\text { C.R. } 475 \mathrm{~W} \text { to conflu- } \\
\text { ence with Sugar Creek }\end{array}$ \\
\hline Lost River & EUW & $\begin{array}{l}\text { Martin, } \\
\text { Orange }\end{array}$ & EUS (IDEM) & $\begin{array}{l}\text { Potato Road to conflu- } \\
\text { ence with East Fork } \\
\text { White River }\end{array}$ \\
\hline $\begin{array}{l}\text { Mud Pine } \\
\text { Creek }\end{array}$ & EUW & Warren & EUS (IDEM) & $\begin{array}{l}\text { S.R. } 352 \text { to confluence } \\
\text { with Big Pine Creek }\end{array}$ \\
\hline
\end{tabular}




\begin{tabular}{|c|c|c|c|c|}
\hline$\underline{\text { River }}$ & Significance & County & GIS Database & $\begin{array}{l}\text { Priority No. } 1 \\
\text { Segment }\end{array}$ \\
\hline $\begin{array}{l}\text { Rattlesnake } \\
\text { Creek }\end{array}$ & EUW & Fountain & EUS (IDEM) & $\begin{array}{l}\text { C.R. } 350 \mathrm{~W} \text { to conflu- } \\
\text { ence with Bear Creek }\end{array}$ \\
\hline Sand Creek & 17 & \multicolumn{2}{|c|}{$\begin{array}{l}\text { Bartholomew, N \& S (IDNR) } \\
\text { Decatur, } \\
\text { Jackson, } \\
\text { Jennings }\end{array}$} & $\begin{array}{l}\text { Westport Covered } \\
\text { Bridge to Brewersville } \\
\text { Road }\end{array}$ \\
\hline Sugar Creek & 7 & $\begin{array}{l}\text { Montgomery, } \\
\text { Parke }\end{array}$ & N \& S (IDNR) & $\begin{array}{l}\text { Darlington Covered } \\
\text { Bridge to confluence } \\
\text { with Wabash River }\end{array}$ \\
\hline $\begin{array}{l}\text { Tippecanoe } \\
\text { River }\end{array}$ & $\begin{array}{l}\text { See } \\
\text { Notes }\end{array}$ & $\begin{array}{l}\text { Kosciusko } \\
\text { Marshall }\end{array}$ & N \& S (IDNR) & $\begin{array}{l}\text { Kosciusko Co. C.R. } \\
700 W \text { to Marshall Co. } \\
\text { Moores Ditch }\end{array}$ \\
\hline $\begin{array}{l}\text { Whitewater } \\
\text { River }\end{array}$ & 7 & $\begin{array}{l}\text { Dearborn, } \\
\text { Fayette, } \\
\text { Franklin }\end{array}$ & N \& S (IDNR) & $\begin{array}{l}\text { Laurel Feeder Dam to } \\
\text { New Trenton Bridge }\end{array}$ \\
\hline Wildcat Creek & HQW & $\begin{array}{l}\text { Carroll, } \\
\text { Tippecanoe }\end{array}$ & N \& S (IDNR) & $\begin{array}{l}\text { S.R. } 29 \text { to confluence } \\
\text { with Wabash River }\end{array}$ \\
\hline $\begin{array}{l}\text { Wildcat Creek, } \\
\text { South Fork }\end{array}$ & HQW & $\begin{array}{l}\text { Clinton, } \\
\text { Tippecanoe }\end{array}$ & N \& S (IDNR) & $\begin{array}{l}\text { S.R. } 38 \text { to confluence } \\
\text { with Wildcat Creek, }\end{array}$ \\
\hline Indiar & & a & ichigan & \\
\hline
\end{tabular}

Rev. $5 / 7 / 02$

Notes: "EUW" means "Exceptional Use Waters" (pursuant to 327 IAC 2-1-11(b). "HQW: means "High Quality Waters" (also referred to as "Outstanding State Resource Waters," pursuant to 327 IAC 2-1-2(3) and 327 IAC 2-1.5-19(b). As to numerical codes: 1 means "outstanding rivers from state inventories or assessments; i.e., rivers identified as having statewide or greater significance;" 17 means "miscellaneous rivers identified as having outstanding ecological, recreational or scenic importance. "EUS (IDEM)" means IDEM's Exceptional Use Streams database. "N \& S (IDNR)" means DNR's Natural and Scenic Rivers database. The five segments coded $\underline{7}$ or 17 are included in the Priority No. 1 list because other segments on this list coded "EUW" and "HQW" are also coded $\underline{7}$ or 17 in the "Outstanding Rivers List for Indiana." The Tippecanoe River Segment is included in the state's Natural and Scenic Rivers inventory and is designated by the National Park Service as qualified for inclusion in the National Wild and Scenic Rivers System.

Source: “Outstanding Rivers List for Indiana," Indiana Natural Resources Commission, Indiana Register, March 1, 1993 and elsewhere, subsequently. 


\section{INDOT PRIORITY NO. 2 \\ Rivers and Streams}

\begin{tabular}{|c|c|c|c|}
\hline$\underline{\text { River }}$ & Significance & GIS Database & $\underline{\text { Segment }}$ \\
\hline Big Creek & 17 & Jefferson & $\begin{array}{l}\text { East side of Jefferson } \\
\text { Military Reservation } \\
\text { boundary to Graham } \\
\text { Creek }\end{array}$ \\
\hline Deep River & 17 & Lake, Porter & $\begin{array}{l}1 \text { mile south of U.S. } 30 \\
\text { to Little Calumet River }\end{array}$ \\
\hline $\begin{array}{l}\text { Graham } \\
\text { Creek }\end{array}$ & 17 & $\begin{array}{l}\text { Jefferson, } \\
\text { Jennings, } \\
\text { Ripley }\end{array}$ & $\begin{array}{l}\text { New Marion to conflu- } \\
\text { ence with Big Creek }\end{array}$ \\
\hline $\begin{array}{l}\text { Indian- } \\
\text { Kentuck } \\
\text { Creek }\end{array}$ & 17 & $\begin{array}{l}\text { Jefferson, } \\
\text { Ripley }\end{array}$ & $\begin{array}{l}\text { Confluence with Vestal } \\
\text { Branch to confluence } \\
\text { with Ohio River }\end{array}$ \\
\hline $\begin{array}{l}\text { Kilmore } \\
\text { Creek }\end{array}$ & 17 & Clinton & $\begin{array}{l}\text { U.S. } 421 \text { to confluence } \\
\text { with South Fork Wild- } \\
\text { cat Creek }\end{array}$ \\
\hline Little Creek & 17 & Jefferson & Kent to Big Creek \\
\hline Mississinewa & 17 & Miami & $\begin{array}{l}\text { Mississinewa Reservoir } \\
\text { to confluence with } \\
\text { Wabash River }\end{array}$ \\
\hline Otter Creek & 17 & $\begin{array}{l}\text { Jennings, } \\
\text { Ripley }\end{array}$ & $\begin{array}{l}\text { Covered Bridge North } \\
\text { of Holton to confluence } \\
\text { with Vernon Fork } \\
\text { Muscatatuck }\end{array}$ \\
\hline Patoka River & 17 & $\begin{array}{l}\text { Dubois, } \\
\text { Gibson, } \\
\text { Pike }\end{array}$ & $\begin{array}{l}\text { Patoka Reservoir to } \\
\text { confluence with } \\
\text { Wabash River }\end{array}$ \\
\hline $\begin{array}{l}\text { Sugar Mill } \\
\text { Creek }\end{array}$ & 17 & $\begin{array}{l}\text { Fountain, } \\
\text { Parke }\end{array}$ & $\begin{array}{l}\text { Wallace to confluence } \\
\text { with Sugar Creek }\end{array}$ \\
\hline $\begin{array}{l}\text { Wildcat Creek, } \\
\text { Middle Fork }\end{array}$ & 17 & $\begin{array}{l}\text { Clinton, } \\
\text { Tippecanoe }\end{array}$ & $\begin{array}{l}\text { S.R. } 26 \text { (Edna Mills) to } \\
\text { confluence with Wild- } \\
\text { cat Creek, South Fork }\end{array}$ \\
\hline
\end{tabular}


INDOT PRIORITY NO. 3

Rivers and Streams

\begin{tabular}{|c|c|c|c|c|}
\hline$\underline{\text { River }}$ & Significance & County & GIS Database & Segment \\
\hline Big Blue & 11 & $\begin{array}{l}\text { Johnson, } \\
\text { Rush, } \\
\text { Shelby }\end{array}$ & & $\begin{array}{l}\text { Flatrock River to } \\
\text { Carthage }\end{array}$ \\
\hline Black River & 11 & Posey & & $\begin{array}{l}\text { Confluence with } \\
\text { Higginbotham Ditch } \\
\text { to confluence with } \\
\text { Wabash River }\end{array}$ \\
\hline Buck Creek & 11 & Harrison & & $\begin{array}{l}\text { Headwaters to conflu- } \\
\text { ence with Ohio River }\end{array}$ \\
\hline $\begin{array}{l}\text { Cypress } \\
\text { Slough Creek }\end{array}$ & 11 & Posey & & $\begin{array}{l}\text { Confluence with } \\
\text { Castleberry Creek to } \\
\text { Southwind Maritime } \\
\text { Center }\end{array}$ \\
\hline Driftwood & 11 & Bartholomew & & $\begin{array}{l}\text { Atterbury Fish and } \\
\text { Wildlife Area to } \\
\text { Columbus }\end{array}$ \\
\hline Fawn & 11 & $\begin{array}{l}\text { Lagrange, } \\
\text { Steuben }\end{array}$ & & $\begin{array}{l}\text { Nevada Mills to } \\
\text { Indiana/Michigan Line } \\
\text { and Indiana/Michigan } \\
\text { to Indiana/Michigan } \\
\text { line }\end{array}$ \\
\hline Fish Creek & 11 & $\begin{array}{l}\text { Dekalb, } \\
\text { Steuben }\end{array}$ & & $\begin{array}{l}\text { Ohio/Indiana line to } \\
\text { Indiana/Ohio Line }\end{array}$ \\
\hline $\begin{array}{l}\text { Fourteen- } \\
\text { Mile Creek }\end{array}$ & 11 & Clark & & $\begin{array}{l}\text { Confluence of East and } \\
\text { West Forks to conflu- } \\
\text { ence with Ohio River }\end{array}$ \\
\hline Indian Creek & 11 & Harrison & & $\begin{array}{l}\text { Floyd/Harrison Co. } \\
\text { Line to confluence with } \\
\text { Ohio River }\end{array}$ \\
\hline
\end{tabular}




\begin{tabular}{|c|c|c|c|c|}
\hline$\underline{\text { River }}$ & Significance & County & GIS Database & $\begin{array}{l}\text { Priority No. } 3 \\
\text { Segment }\end{array}$ \\
\hline Kankakee & 11 & $\begin{array}{l}\text { LaPorte, } \\
\text { Newton, } \\
\text { Porter }\end{array}$ & & $\begin{array}{l}\text { Upstream boundary of } \\
\text { Kingsbury Fish and } \\
\text { Wildlife Area through } \\
\text { LaSalle State Fish and } \\
\text { Wildlife Area to } \\
\text { Indiana/Illinois line }\end{array}$ \\
\hline $\begin{array}{l}\text { Laughery } \\
\text { Creek }\end{array}$ & 11 & $\begin{array}{l}\text { Dearborn, } \\
\text { Ohio, } \\
\text { Ripley }\end{array}$ & & $\begin{array}{l}\text { Source just east of } \\
\text { Morris in Ripley Co. to } \\
\text { confluence with Ohio } \\
\text { River }\end{array}$ \\
\hline Little Blue & 11 & Crawford & & $\begin{array}{l}\text { Town of English to } \\
\text { confluence with Ohio }\end{array}$ \\
\hline $\begin{array}{l}\text { Little Indian } \\
\text { Creek }\end{array}$ & 11 & Harrison & & $\begin{array}{l}\text { Pfrimmer Church to } \\
\text { confluence with Indian } \\
\text { Creek }\end{array}$ \\
\hline $\begin{array}{l}\text { Little } \\
\text { Mosquito }\end{array}$ & 11 & Harrison & & $\begin{array}{l}\text { Headwaters to conflu- } \\
\text { ence with Mosquito } \\
\text { Creek }\end{array}$ \\
\hline $\begin{array}{l}\text { Little Pine } \\
\text { Creek }\end{array}$ & 11 & Warren & & $\begin{array}{l}\text { Bridge SW of Green } \\
\text { Hill to confluence with } \\
\text { Wabash River }\end{array}$ \\
\hline $\begin{array}{l}\text { Mosquito } \\
\text { Creek }\end{array}$ & 11 & Harrison & & $\begin{array}{l}\text { Buena Vista to conflu- } \\
\text { ence with East Fork } \\
\text { White River }\end{array}$ \\
\hline $\begin{array}{l}\text { Muscatatuck, } \\
\text { Vernon Fork }\end{array}$ & 11 & $\begin{array}{l}\text { Jackson, } \\
\text { Jennings }\end{array}$ & & $\begin{array}{l}\text { Zenas to confluence } \\
\text { with Muscatatuck Fork }\end{array}$ \\
\hline Oil Creek & 11 & Perry & & $\begin{array}{l}\text { St. Croix to confluence } \\
\text { with Ohio River }\end{array}$ \\
\hline Pigeon & 11 & LaGrange & & $\begin{array}{l}\text { S.R. } 327 \text { to Indiana/ } \\
\text { Michigan Line }\end{array}$ \\
\hline $\begin{array}{l}\text { Rattlesnake } \\
\text { Creek }\end{array}$ & 11 & Parke & & $\begin{array}{l}\text { C.R. } 400 / 450 \text { S to } \\
\text { confluence with Sugar } \\
\text { Creek }\end{array}$ \\
\hline
\end{tabular}




\begin{tabular}{|c|c|c|c|}
\hline$\underline{\text { River }}$ & Significance & GIS Database & $\begin{array}{l}\text { Priority No. } 3 \\
\text { Segment }\end{array}$ \\
\hline $\begin{array}{l}\text { Roaring } \\
\text { Creek }\end{array}$ & 11 & Parke & $\begin{array}{l}1 \text { mile upstream of } \\
\text { S.R. } 41 \text { to confluence } \\
\text { with Sugar Creek }\end{array}$ \\
\hline $\begin{array}{l}\text { Stinking } \\
\text { Fork }\end{array}$ & 11 & Crawford & $\begin{array}{l}\text { Headwaters to conflu- } \\
\text { ence with Little Blue } \\
\text { River }\end{array}$ \\
\hline Sugar Creek & 11 & $\begin{array}{l}\text { Johnson, } \\
\text { Shelby }\end{array}$ & $\begin{array}{l}\text { Inclusive within } \\
\text { Johnson and Shelby } \\
\text { Counties }\end{array}$ \\
\hline Turkey Fork & 11 & Crawford & $\begin{array}{l}\text { I- } 64 \text { to confluence with } \\
\text { Little Blue River }\end{array}$ \\
\hline $\begin{array}{l}\text { White River, } \\
\text { East Fork }\end{array}$ & 11 & $\begin{array}{l}\text { Bartholomew, } \\
\text { Daviess, Dubois, } \\
\text { Jackson, Lawrence, } \\
\text { Martin, Pike }\end{array}$ & $\begin{array}{l}\text { Columbus to conflu- } \\
\text { ence with West Fork }\end{array}$ \\
\hline $\begin{array}{l}\text { White River, } \\
\text { West Fork }\end{array}$ & 11 & $\begin{array}{l}\text { Daviess, } \\
\text { Delaware, Gibson, } \\
\text { Knox, Greene, } \\
\text { Hamilton, Madison, } \\
\text { Marion, Morgan, } \\
\text { Owen, Randolph }\end{array}$ & $\begin{array}{l}\text { Farmland to conflu- } \\
\text { ence with Wabash } \\
\text { River }\end{array}$ \\
\hline
\end{tabular}

Rev. 5/7/02

Notes: Numerical code $\underline{11}$ means "rivers identified by state natural heritage programs or similar state programs as having outstanding ecological importance."

Source: “Outstanding Rivers List for Indiana," Indiana Natural Resources Commission, Indiana Register, March 1, 1993 and elsewhere, subsequently. 
APPENDIX K 


\section{APPENDIX L}




\section{APPENDIX M}


APPENDIX N 

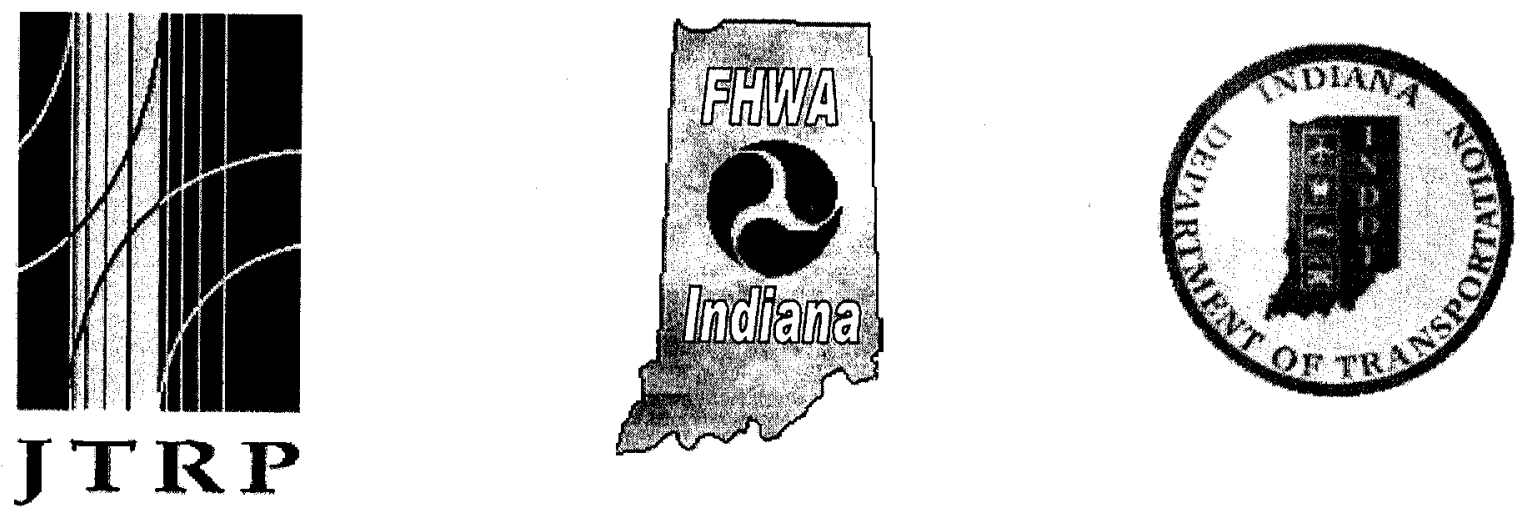

\section{Technology Deployment Work Group}

\section{Innovative Environmental Management of Winter Salt Runoff Problems}

Submitted to:

\section{Indiana Department of Transportation Executive Staff}

August 1, 2003 


\section{Contents}

\begin{tabular}{|c|c|c|}
\hline Seculon & 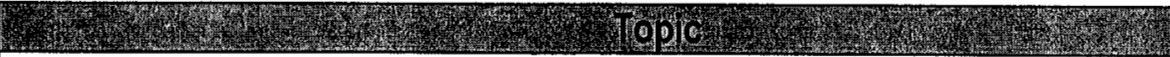 & Pare \\
\hline I & $\begin{array}{l}\text { Introduction } \\
\text { A. Need Assessment and Project Description } \\
\text { B. Technology Description }\end{array}$ & $\begin{array}{l}1 \\
1\end{array}$ \\
\hline II & $\begin{array}{l}\text { Technology Analysis } \\
\text { A. Technology Background/Profile \& Analysis } \\
\text { B. Current Practice in Indiana } \\
\text { C. Market Profile and Segments } \\
\text { D. Technology Support } \\
\text { E. Cost/Benefit Evaluation } \\
\text { F. Suggested Funding Sources }\end{array}$ & $\begin{array}{l}3 \\
3 \\
4 \\
4 \\
4 \\
6\end{array}$ \\
\hline III & $\begin{array}{l}\text { Goals and Objectives } \\
\text { A. Short- Term Goals and Objectives for Implementation } \\
\text { B. Long- Term Goals and Objectives for Impiementation }\end{array}$ & $\begin{array}{l}7 \\
7\end{array}$ \\
\hline IV & $\begin{array}{l}\text { Recommended Implementation Strategies and Requirements } \\
\text { A. Action Items } \\
\text { B. INDOT/Partner - Personnel involvement, Task, and Responsibilities }\end{array}$ & $\begin{array}{l}9 \\
9\end{array}$ \\
\hline V & $\begin{array}{c}\text { Success Measurements } \\
\text { A. Milestones }\end{array}$ & 11 \\
\hline Vl & Summary Statement & 12 \\
\hline
\end{tabular}




\section{Innovative Environmental Management of Winter Salt Runoff Problems}

\section{Introduction}

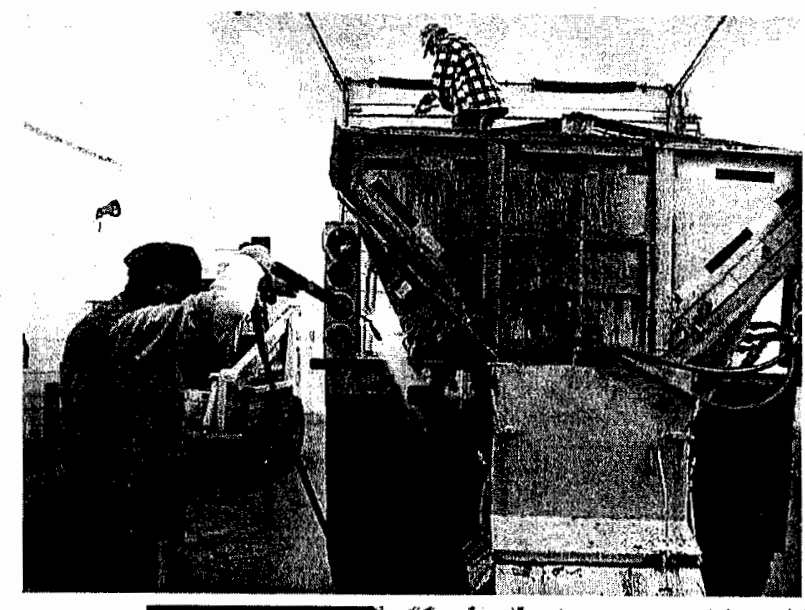

A. Need Assessment \& Problem Description

A survey of INDOT maintenance facilities, updated in 2001, found that $57 \%$ of the facilities do not have sewered wastewater connections to a publicly owned treatment plant (POTW) and that, as a result, many of the remaining facilities have off-site discharges to the environment. These sites will have to obtain NPDES permits with associated contaminant discharge limitations and liabilities for exceedance events and affiliated mitigation activities.

Furthermore, under the Stormwater Phase II regulations of NPDES, state transportation facilities fall under operators of MS4 areas and will be required to implement stormwater control measures. IDEM is currently establishing a total maximum daily load (TMDL) for chloride. In addition, as of 2002, IDEM has established a $250 \mathrm{mg} / \mathrm{l}$ limit (DWS) for chloride in groundwater. It has been indicated by INDOT

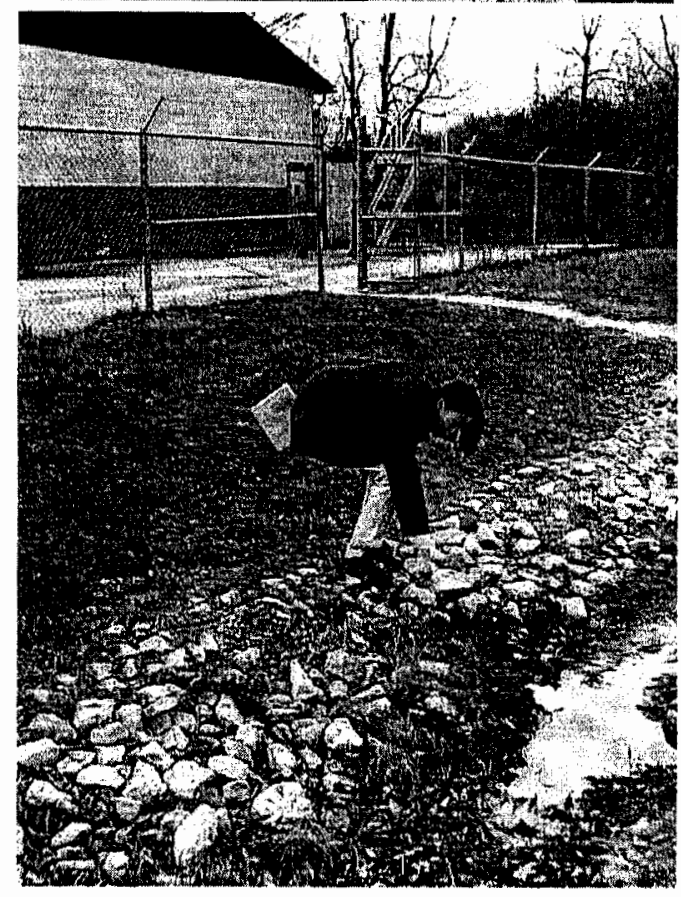
personnel that INDOT may spend up to $\$ 20$ million annually to ensure compliance to these new stormwater/groundwater regulations.

A recent INDOT/JTRP research and implementation project examined an innovative strategy for mitigating, and possibly obviating, the environmental impact of wintertime salt release within INDOT yard areas specifically associated with the generation and release of salt truck wash waters, whereby these waste streams may be beneficially reused in the manufacture of salt brine solutions suitable for subsequent pre-wetting and anti-icing applications. Consequently, statewide implementation of this technology will not only assist in compliance with environmental regulations, but also a materials savings through the capture and reuse of deicing materials, previously discharged into the waste stream.

\section{B. Technology Description}

The capture of the salt laden waste streams and reuse of the brine solutions back onto the roadway is a proven concept which has been utilized by other DOTs as well as by some INDOT facilities. However, the use of brine makers by INDOT has been sporadic with some districts (e.g. LaPorte and Vincennes) more fully using the technology, largely because of local INDOT 
'champions' of the technology in those districts. To facilitate implementation of this technology the INDOT/JTRP Research Program sponsored implementation projects in the Bainbridge (Crawfordsville District) and Bluffton (Fort Wayne District) sub-districts to assist district personnel. Furthermore, as the department upgrades district facilities, connection to POTWs or recovery/reuse options of the waste stream are included. However, at the current pace and funding level, it will be years before INDOT facilities can take full advantage of

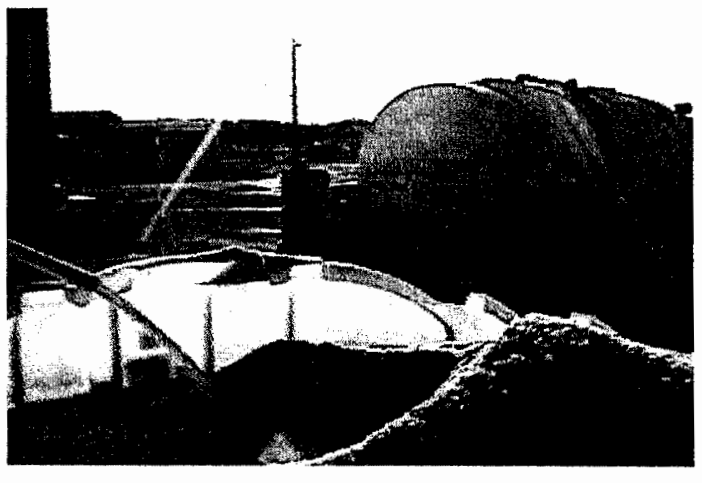
the brine making technology.

Both implementation projects were successful and this experience was captured and has been made available for statewide review and consideration in two formats, including both a virtual, Web-based (http://rebar.ecn.purdue.edu/Salt\%20Wash\%20Reuse/HT ML master BEST.htm) as well as a CD-ROM. Upcoming distribution of this latter $C D$ throughout all INDOT districts will subsequently provide hands-on information regarding processing schematics, specifications, vendors, costs, operating and maintenance procedures, etc.

Primarily, the technology includes an oil/water separator, sedimentation/retention tank for wash water, brine making tank, storage tank(s), and pumps. Information on sizes, costs, vendors, how to do-it-yourself and available commercial systems are available in the final research report and CD Rom. For comparison, a do-it-yourself brine making system in the Monticello sub-district cost an estimated $\$ 3,055$. 


\section{Technology Analysis}

\section{A. Technology Background/Profile \& Analysis}

This proposal focuses on the resolution of a specific environmental problem (i.e., salt truck wash water management) while at the same time promoting the general use of brine for highway antiicing and de-icing purposes. The latter concept (i.e., that of liquid brine manufacture and use in conjunction with winter operations...in lieu of a total reliance on dry salt) has, in fact, recently drawn considerable DOT interest throughout the Midwest over the past few years. For example, the State of lowa has extensively invested in brine manufacture and spreading equipment with the clear intent of shifting significantly from dry salt use while extensively upgrading their alternative use of brine.

In retrospect, this shift towards brine use appears to offer several benefits, including:

a) potentially lower salt use levels and costs,

b) potentially improved salt distribution (i.e., using controlled liquid spray versus dry salt application)

c) possible use of surface pre-coating salt application strategies (e.g., via routine, or at least pre-storm, brine application to severe icing locations at bridge surfaces, etc.), and

c) improved highway safety via reduced icing.

INDOT has not, as yet, extensively pursued this adoption of liquid brine use, and has only a handful of facilities currently equipped to pursue liquid brine manufacture and spreading. Irrespective of this transition to brine use, though, the fact remains that salt-contaminated wash waters still represent an unresolved, and decidedly serious, environmental problem. Buying, installing, and then using brine manufacturing equipment, as recommended within this proposal, would consequently afford a unique 'win-win' situation, whereby contaminated wash water could be beneficially collected and reused in conjunction with brine manufacture and application.

B. Current Practice in Indiana

Salt truck wash water collection and reuse, in relation to brine manufacture and application is currently practiced at, at least, six (6) known locations in the State of Indiana. In two instances (i.e., LaPorte and Monticello), the involved brine manufacturing equipment was constructed on a do-it-yourself basis, while in the remaining four locations (i.e., Princeton, Bluffton, Gary and Bainbridge) commercial equipment

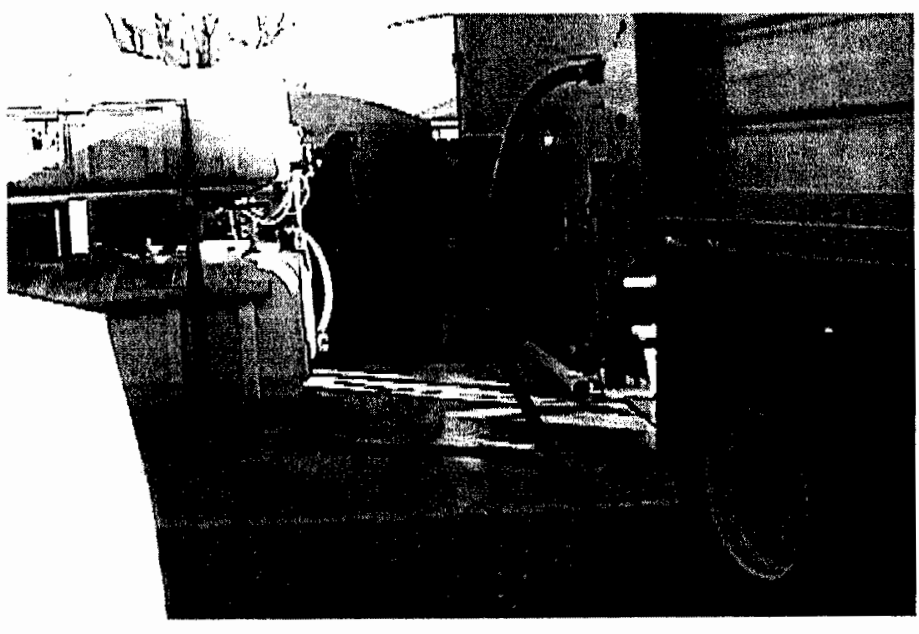
for brine manufacture was used. Given that all six of these 'proof-of-concept' operations can be considered successful in regard to solving their wash water problems, it would quite likely be that a conservative approach to broadening this concept using commercially-available hardware would be similarly successful at any INDOT site. 


\section{Market Profile and Segments}

While all of the existing five (5) sites mentioned above who are currently using this 'wash water brine reuse' concept are all INDOT facilities, it is nonetheless apparent that county and city road management operations are realizing an increased level of brine use for both deicing and anti-icing purposes either by applying purchased or locally-generated brine solutions. In turn, it would certainly appear that INDOT's initiative to resolve their environmental problem of salt truck wash water disposal through collection and reuse as brine would likely yield a trickledown stimulus for further dissemination of this technology into country and city operation.

\section{Technology Support}

The following individuals have provided, and can be expected to provide, technical support for developing and then implementing this concept, with representation collectively covering not only INDOT and FHWA but also

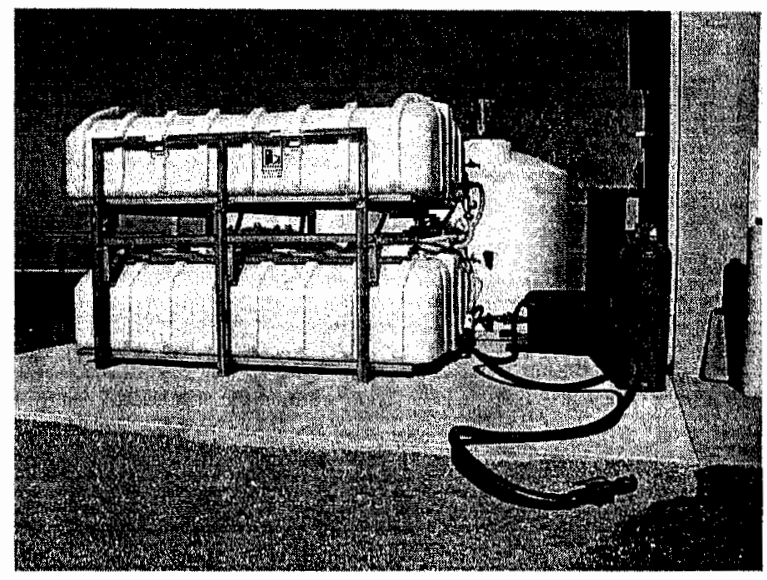

Purdue University:

\section{INDOT Personnel}

Dennis Belter, the INDOT Winter Operations Team (WOT) Chairman; the WOT is in support of implementing this technology statewide. A decision that this is the direction the department will pursue needs to be made for statewide and consistent application. Funding will need to be identified as noted below. The WOT will be the point of contact for districts and sub-districts requiring technical support.

\section{Purdue University}

The WOT will be able to draw upon the expertise of Purdue facuity and staff (e.g. Prof. Alleman, Dr. Corson, and Dr. Bob McCullouch) for technical assistance, as well as INDOT Research Division support and vendor support. In addition, comparable implementation efforts at the county and city level could also promoted and catalyzed by way of the annual Purdue-JTRP 'Road School' program, as well as through regional workshops and "on-site" technical assistance provided via Purdue's LTAP group (i.e., Local Technical Assistance Program).

\section{Federal Highways Administration}

FHWA also supports this technology effort and will provide support, including financial support and funding approval where possible.

\section{E. Cost/Benefit Evaluation}

\section{Cost/Benefit Ratio}

Option \#1: Sewer Installation and POTW Discharge - Given that on-site discharge is no longer an 'option' with salt truck wash water, one possible waste management option for INDOT facilities 
lacking sewer connections to a local POTW would be to install a sewer, assuming of course that this POTW can be convinced to accept this intermittent, high-strength waste stream. This 'assumption' has significant implications, however, and current indications suggest that some POTW's may not be all that willing to accept such wastes. Not only does the wash water have a high-salt content, but these streams also tend to contain cyanide-bearing chemicals originally added to the salt as anti-caking agents. INDOT-supported research via the JTRP program is currently underway to resolve these latter underlying environmental issues, and hopefully these findings will have a positive outcome which pro-actively facilitates this 'willingness' should this option prove necessary. In terms of costbenefit, however, this option of installing a new sewer will undoubtedly be costly. This strategy, and its associated cost/benefit aspects, has indeed been documented by Dr. Lynn Corson with Purdue University's Clean Manufacturing and Technology Institute within their report entitled, "SPR-2458: Comparative Cost: Connecting to POTW vs. Pump and Haul to Dispose of Washbay Effluent" (see the following Web site: http://www.ecn.purdue.edu/CMT//INDOT). For example, with a connection length of only 1.0 mile (real case example), the sewer's installation would cost was $\sim \$ 400,000$, at which point this option does not appear to have an acceptable cost/benefit ratio.

Option \#2: Pump-and-Haul-to-POTW - A second possible option would be that of a 'pump-andhaul' disposal process, where waste is pumped into a transport truck and hauled to a local POTW. Costbenefit figures given in the aforementioned report indicate an estimated pump-and-haul fee plus discharge fee of approximately $\$ 7,200$ for a 25,000 gallon washbay waste volume hauled 30 miles... which would roughly correspond to 80-90 truck wash events (i.e., at an estimated per-truck wash water volume of 250-300 gallons). For a typical sub-district yard, therefore, with 4 to 6 trucks whose cumulative washing events on a 'per-year' basis might well reach this 80 to 100 figure, this would then equate to an annual, recurring operating cost.

Option \#3: Collection-and-Reuse-with-Brine-Manufacture - The installed capital cost of a new, commercial brine-manufacturing unit and associated sprayer would be approximately $\$ 10,000$ to $\$ 12,000$, and an additional expenditure of approximately $\$ 4,000$ might be required to site-specific plumbing and pumping fixtures. In turn, the apparent 'payback' on these costs, as compared to pump-and-haul costs would be approximately two years.

Option \#4: Centralized Approach to Option \#3 - As compared to installing wash water recovery and brine making equipment at all INDOT facilities, though, consideration might also be given to centralizing truck washing operations. Based on an assumption that INDOT trucks could be driven 20 miles to such a central operation, the previously cited report lists a projected cost of $\$ 539 /$ unitseason... which suggests that this implementation strategy warrants further consideration and deliberation amongst INDOT district operations personnel.

\section{Implementation Cost}

The estimated hardware and installation costs for each on-site implementation of this technology would be as follows:

- Estimated wiring and plumbing installation costs - \$2000/site 
(NOTE: in many instances, INDOT personnel could likely handle these tasks)

- Estimated brine manufacturing hardware - $\$ 6000$ to $\$ 8000$

(this cost varies in relation to various vendor options)

- Estimated brine storage and transfer (pumping) hardware - $\$ 2800$ to $\$ 3500$

(this cost depends upon storage volume, but 2000 gal would typically be adequate)

- Estimated brine sprayer hardware - $\$ 6000$ to $\$ 8000$

(here again, this cost varies depending upon vendor options)

Total Installation and Capital Cost Range @ approximately $\$ 15,000$ - $\$ 18,000$

(NOTE: use of local INDOT personnel for wiring, plumbing, etc., is feasible, and may reduce costs by $\sim \$ 3000$ )

\section{Maintenance and Other Costs}

Maintenance and operating costs will inevitably be incurred with this new hardware. Although only nominal personnel time will be required for wash water collection and passage through an oil-water separator (i.e., this hardware is largely automated), personnel time will be required to run the brine maker, brine storage, and brine pumping equipment.

However, all of these latter 'costs' would be the same for brine production, irrespective of the wash water input. Furthermore, the most significant maintenance activities with brine making is that of flushing out inert debris at the end of the winter season, and here again this commitment in personnel time would not change whether the brine was made with a fresh or wash water source.

F. Suggested Funding Sources (FHWA, INDOT, reprogramming of funds, etc)

As noted, INDOT personnel has indicated funding levels of up to $\$ 20$ million annually will be require for compliance to the recently promulgated stormwater/groundwater regulations. It is conceivable some of this funding could be directed towards statewide implementation of brine making systems. It is possible this could be staged whereby those facilities without access to sanitary sewers would install brine making facilities first. FHWA is also investigating the availability of implementation funding or redirection of existing funding. 


\section{Goals and Objectives}

Final decisions on goals and objectives should be established by INDOT's WOT, Districts, and Environment, Planning, and Engineering Division in consultation with Steve McAvoy, relative to a number of key variables (e.g., sewer and haul distances to area POTWs, willingness of local POTW to accept INDOT wash water waste flows, regional decisions regarding centralized truck wash and waste reuse installations, etc.). The following synopsis, however, provides a broad perspective of the likely short- and long-term goals and objectives for this proposed implementation effort:

\section{A. Short-Term Goals and Objectives for Implementation (first 3 month timeframe)}

The following four (4) short-term goals and their associated objectives will facilitate an initial kickoff of this concept to be completed within the first three months, as follows:

\section{1) Executive Resolution}

The first step in this entire process is to receive formal approval for future implementation of this concept via INDOT Executive Staff resolution.

\section{2) Establish Funding Initiatives}

Having been authorized to proceed with full implementation, an organized strategy to secure necessary funding will need to be laid out and initiated.

\section{3) Develop WOT and District Consensus}

WOT and District consensus at an early and formative stage with this implementation concept will be critical to its success. Therefore, an organized plan for this process must be developed and launched, with consistent follow-through and updates for all key parties.

\section{4) Development of District Implementation Plans}

After having secured WOT, Operations Support and District consensus, it would be highly beneficial if these Districts, in consultation with INDOT, assumed ownership of all subsequent tasks and established 'action teams' to carry out these plans, with their efforts guided and optimized in consultation with assigned INDOT and Purdue 'champions' (e.g., INDOT's Dennis Belter plus Dr. Barry Partridge, as well as Drs. Jim Alleman and Bob McCullouch with Purdue's JTRP program).

\section{B. Long-Term Goals and Objectives for Implementation (subsequent 24 month timeframe)}

The following six (6) long-term goals and their associated objectives will carry the project through sequential procurement, installation, training, and assessment phases over a 24 month period:

\section{1) Hardware Selection and Procurement}

Once funding has been resolved, and after due consideration and selection by the involved INDOT district 'action team' the necessary hardware should then be purchased. Given that there are various commercial options presently available, it might be wise at this point...or at least early on in the project...to procure at least two options such that their relative characteristics could be duly calibrated (e.g., ease of use, ease of cleaning, hardware performance, etc.). Here again, specific guidance relative to the overall concept, hardware 
options, and even 'do-it-yourself' strategies has already been prepared and made available via the following Web hotlink location:

http://rebar.ecn.purdue.edu/Salt\%20Wash\%20Reuse/HTML master BEST.htm

CD copies of the technical materials provided at this Web location can be secured via Dr. Bob McCullouch with JTRP (Note: contact information, including address, email, and phone, for Dr. McCullouch is given on the opening page of this Web hotlink).

\section{2) Hardware Installation}

Once the hardware has been bought and shipped, the INDOT district 'action team' will then have to establish a working plan for installing the equipment...perhaps using a roving, assigned group of INDOT technicians whose skill set has been refined through successive installations.

\section{3) Operational Training}

Aside from hardware installation, the 'action team,' with any needed assistance from the WOT and research personnel, will also have to provide hands-on training for all involved INDOT personnel, which could be done during and immediately after hardware installation.

\section{4) Startup and Optimization}

The last on-site task for the 'action team,' following hardware setup and operator training, would then be to work with the local INDOT facility personnel during a startup and debugging period, such that these local personnel develop a hands-on familiarity and confidence with the involved equipment.

\section{5) Performance Assessment}

In order to calibrate the ongoing effectiveness of this effort, and to gauge whether any corrective actions need be taken to insure final success of the project, routine performance assessments should be conducted on a joint basis by the WOT in conjunction with 'action team' members.

\section{6) Project Closure and National DOT Dissemination}

As the last step in what is likely to be a highly successful closure of this project, national dissemination of a report covering this effort would then be warranted...in a forum such as the Transportation Research Board program. FHWA can also assist in disseminating the results of this effort to other state DOTs via existing FHWA technology transfer programs. 


\section{Recommended Implementation Strategies and Requirements}
A. Action Items

\begin{tabular}{|c|c|c|}
\hline \multicolumn{3}{|c|}{ Recommended Implementation Sirategy Action ltems and Timefirames } \\
\hline \multicolumn{3}{|c|}{ Short- Term Implementation Action Items and Timeframes } \\
\hline 1 & Executive Resolution & Immediate ( 1 day timeframe) \\
\hline 2 & Establish Funding Initiatives & $\begin{array}{l}\text { Start immediately after Executive Resolution... with } \\
\text { ongoing activity ( } 3 \text { week timeframe) }\end{array}$ \\
\hline 3 & Develop District Consensus & $\begin{array}{l}\text { Start immediately after Executive Resolution }(\sim 1 \\
\text { month startup... with routine follow-up) }\end{array}$ \\
\hline 4 & Development of District Implementation Plans & $\begin{array}{l}\text { Start after District consensus activity ( } 2 \text { months, with } \\
\text { ongoing follow-up via 'action team' assignments) }\end{array}$ \\
\hline \multicolumn{3}{|c|}{ Long-Term Goals and Objectives for Implementation } \\
\hline 1 & Hardware Selection and Procurement & $\begin{array}{l}\text { Start after resolving funding.... and pursuant to } \\
\text { District consensus and 'action team' formation ( } 2 \\
\text { month effort) }\end{array}$ \\
\hline 2 & Hardware Installation & $\begin{array}{l}\text { Start immediately once equipment arrives }(\sim 1 \\
\text { week per site) }\end{array}$ \\
\hline 3 & Operational Training & $\begin{array}{l}\text { Start during equipment installation ( } \sim 3 \text { days per } \\
\text { site) }\end{array}$ \\
\hline 4 & Startup and Optimization & $\begin{array}{l}\text { Start following site installation wrapup ( } 2 \text { days } \\
\text { per site) }\end{array}$ \\
\hline 5 & Performance Assessment & 2 month 'action team' effort to wrap up project \\
\hline 6 & Project Closure and National DOT Dissemination & $\sim 2$ months preparation and presentation effort \\
\hline
\end{tabular}

B. INDOT/Partner - Personnel involvement, Task, and Responsibilities

INDOT Personnel

Dennis Belter and WOT - estimated time commitment $\sim 1$ month total time over 24 month project period

\section{Purdue University}

Drs Jim Alleman, Bob McCullouch, and Lynn Corson - estimate time commitment $\sim 2$ month each over 24 month project period 


\section{Federal Highways Administration}

Direct personnel time commitment not projected, but supplemental guidance and assistance with dissemination of results might be beneficial to all parties 


\section{Success Measurements}

\section{A. Milestones}

The following eight (8) step 'milestone calibration process' is recommended in terms of qualifying the obtained level of 'success' with this implementation effort:

1. District Consensus Assessment Calibration

Step \#1

2. District 'Action Team' Formations

Step \#2

3. 'Action Team' Planning Assessment

Step \#3

4. 'Action Team' Hardware Selection \& Procurement

Step \#4

5. 'Action Team' Hardware Installation Assessment

Step \#5

6. Full Equipment Startup and Operation Assessment

Step \#6

7. Full Equipment Usage Assessment

Step \#7

8. Post-Implementation Closure Assessment

Step \#8 


\section{Summary Statement}

Brine making systems involve a proven technology which is currently used by other DOTs, albeit sporadically, by INDOT. Use within INDOT appears to be dependent on having knowledgeable 'champions' of the technology in a district, rather than problems with the technology itself. There is an effort by INDOT to construct new facilities with brine making capabilities as funding becomes available.

With the advent of new stormwater/groundwater regulations, and the successful research effort indicating the viability of brine making, a more determined and uniform approach to introduce brine making statewide appears needed. To facilitate this effort, implementation projects at the Bainbridge (Crawfordsville district) and Bluffton (Fort Wayne district) sub-districts were undertaken to assist district personnel, demonstrate the viability of the technology and to document information related to schematics, specifications, vendors, costs, operating \& maintenance procedures, etc. for future use in statewide implementation. Both implementation projects were successful and a CD Rom will shortly be available documenting these projects and information gathered.

In addition to deciding to implement brine making statewide, funding will need to be identified. However, INDOT personnel have noted that compliance with new stormwater/groundwater environmental regulations may cost the department up to $\$ 20$ million dollars annually. If brine making systems can help satisfy environmental regulations (either by removing a contaminant from a waste stream or by reducing the concentration to an acceptable level), as well as result in a materials savings through the capture and reuse of deicing materials, which were previously discharged into the waste stream, it would be timely to consider brine making as a 'best management practice' (i.e., BMP) towards compliance with the environmental regulations and direct funding towards statewide implementation. Furthermore, FHWA is investigating the availability of implementation funding and redirection of current funding.

Lastly, a more uniform approach to implementing brine making statewide has the support of INDOT's Winter Operations Team, which is willing to serve as a leader and point of contact in this endeavor. Additional support is available through the INDOT/JTRP Research Program as well as technical support typically provided by vendors.

The bottom line to this proposal is that this technology is being recommended to the INDOT Executive Staff for adoption. 
APPENDIX 0 


\section{Crawfordsville District}

Avon 23

Battle Ground 4

Brownsburg $\quad 76$

Crawfordsville $\quad 350$

Danville $\quad 30$

Dayton 2

Frankfort $\quad 166$

Lebanon $\quad 145$

Lafayette \& West Lafayette $\quad 600$

Pittsboro 36

Plainfield 270

Seelyville 5

Shadeland 0

Terre Haute \& North Terre Haute $\quad 385$

West Terre Haute 99

Zionsville

TOTAL

\section{Fort Wayne District}

$\begin{array}{lr}\text { Allen County } & 1,400 \\ \text { Angola } & 55 \\ \text { Auburn } & 96 \\ \text { Bristol } & 70 \\ \text { Columbia City } & 68 \\ \text { Decatur } & 212 \\ \text { Dunlap } & 71 \\ \text { Elkhart City } & 513 \\ \text { Elkhart County } & 127 \\ \text { Fort Wayne } & 906 \\ \text { Goshen } & 493 \\ \text { Huntington City } & 161 \\ \text { Huntertown } & 32 \\ \text { Kendallville } & 23 \\ \text { Leo/Cedarville } & 35 \\ \text { Marion } & 459 \\ \text { New Haven } & 435 \\ \text { New Paris } & 2 \\ \text { Peru } & 82 \\ \text { Simonton Lake Corp. } & 53 \\ \text { Wabash City } & 143 \\ \text { Warsaw } & 194 \\ \text { TOTAL } & \mathbf{5 , 6 3 0}\end{array}$




\section{LaPorte District}

Burns Harbor 95

Cedar Lake 16

Chesterton 79

Crown Point 30

Dyer 53

East Chicago 398

Gary $\quad 1114$

Georgetown 0

Granger CDP 7

Gullivoire Park 79

Griffith 115

Hammond 930

Highland 341

Hobart $\quad 140$

Lake County 347

Lake Dalecarlia CDP 0

Lake Station 176

Lakes of the Four Seasons CDP 0

LaPorte 341

LaPorte County $\quad 1020$

Logansport 135

Long Beach 0

Lowell 14

Merrillville 453

Michigan City $\quad 528$

Mishawaka 255

Munster 0

New Chicago 0

Ogden Dunes 0

Osceola 2

Plymouth 48

Portage 252

Porter 8

Porter County 475

Roseland 72

St. Joseph County 361

St. John 9

Schererville $\quad 340$

South Bend 467

South Haven CDP 6

Trail Creek 81

Valparaiso 11

Whiting $\underline{113}$

TOTAL $\quad 8,911$ 


\section{Greenfield District}

$\underline{\text { Indianapolis Subdistrict }}$

Beech Grove 0

Cumberland $\quad 36$

Lawrence _. 44

McCordsville 22

Southport 0

Speedway 0

Greenfield Subdistrict

Anderson

Chesterfield

Edgewood

Greenfield $\quad 144$

New Palestine 23

Shelbyville $\quad 141$

Centerville Subdistrict

Connersville 263

New Castle $\quad 373$

Richmond 496

Tipton Subdistrict

Arcadia

Carmel

Cicero

32

Clarksville 0

Fishers 24

Fortville $\quad 38$

Ingalls 1

Kokomo 157

Noblesville $\quad 181$

Pendleton 27

Westfield $\quad 377$

Ridgeville Subdistrict

\begin{tabular}{lr}
\hline Alexandria & 3 \\
Daleville & 3 \\
Georgetown & 0 \\
Muncie & 4 \\
Parker City & 2 \\
Yorktown & 2 \\
TOTAL & $\frac{2}{\mathbf{3 , 0 4 6}}$
\end{tabular}




\section{Vincennes District}

Linton $\quad 600$

Evansville $\quad 2200$

Paoli $\quad 800$

Tell City $\quad 1360$

Vincennes $\quad \underline{800}$

TOTAL $\quad 5 \overline{5,760}$

\section{$\underline{\text { Seymour District }}$}

Falls City Subdistrict

SR 111 Grantline Road, Floyd Co. 117

SR 111 New Albany, Floyd Co. 181

US 150 Galena, Floyd Co. 13

SR 311 Sellersburg, Clark Co. $\quad 14$

SR 64 Georgetown, Floyd Co. 22

US 31 Sellersburg, Floyd Co. 33

Columbus Subdistrict

\begin{tabular}{llr}
\hline Columbus & SR 46 & 143 \\
& US 31 & 36 \\
Greensburg & SR 46 & 35 \\
& US 421 & 16 \\
Seymour & US 50 & 158 \\
& SR 11 & 52 \\
& SR 258 & 7 \\
Bargersville & SR 135 & 4 \\
& SR 144 & 2 \\
Edinburgh & SR 252 & 5 \\
Franklin & SR 44 & 23 \\
& US 31 & 13 \\
Greenwood & US 31 & 140 \\
& SR 135 & 138 \\
Whiteland & US 31 & 0 \\
New Whiteland US 31 &
\end{tabular}

Aurora Subdistrict

Aurora \& Lawrenceburg US $50 \quad 138$ (of which 28 are catch basins) 
Bloomington Subdistrict * NO inlets or catch basins in this Subdistrict drain to an MS4 system Bloomington SR 46 *288 (of which 12 are catch basins) SR 45 *84 (of which 20 are catch basins) SR 48

(of which 6 are catch basins)

Madison Subdistrict

Madison, Jefferson Co.

TOTAL

$\underline{111}$

Toll Road

Hammond System $\quad 168$

Gary System 193

Wolf Lake $\quad 10$

Grand Calumet River

Subtotal $\quad \frac{84}{355}$

TOTAL to municipal systems $\quad 361$

GRAND TO'TAL to municipal systems $\quad 27,364$

GRAND TOTAL INLETS $\quad 27,769$ 
APPENDIX P 
MEMORANDUM OF UNDERSTANDING

(Reprinted for clarity, original on file)

THIS MEMORANDUM OF UNDERSTANDING IS MADE AND ENTERED INTO THIS THIRTEENTH DAY OF OCTOBER, 1993 BETWEEN THE INDIANA DEPARTMENT OF TRANSPORTATION (INDOT), THE INDIANA DEPARTMENT OF NATURAL RESOURCES (IDNR), THE INDIANA DEPARTMENT OF ENVIRONMENTAL MANAGEMENT (IDEM), AND THE U.S. FISH AND WILDLIFE SERVICE (USFWS) FOR THE PURPOSE OF DELINEATING GUIDELINES FOR CONSTRUCTION OF TRANSPORTATION PROJECTS IN KARST REGIONS OF THE STATE.

WHEREAS, INDOT, IDNR, IDEM AND THE USFWS WISH TO COOPERATE IN THE IDENTIFICATION, STUDY AND TREATMENT OF DRAINAGE IN KARST REGIONS RELATED TO THE CONSTRUCTION OF TRANSPORTATION PROJECTS AND,

WHEREAS, INDOT, IDNR, IDEM AND THE USFWS ACCEPT RESPONSIBILITY TO ENSURE THE TRANSPORTATION NEEDS OF INDIANA ARE MET IN AN ENVIRONMENTALLY SENSITIVE MANNER THAT PROTECTS THE HABITAT OF ALL SPECIES AND,

WHEREAS, DESIGN AND CONSTRUCTION PRACTICES MUST PROTECT GROUND WATER QUALITY, PUBLIC HEALTH AND SAFETY, AND THE ENVIRONMENT.

WHEREAS, IDNR WILL CONFORM TO THE TERMS AND CONDITIONS OF THIS MOU ON THEIR TRANSPORTATION PROJECTS. LIKEWISE, IT WILL BE IDNR'S RESPONSIBILITY TO PROVIDE STANDARD BIOLOGICAL REVIEW FOR PROJECTS IN THE KARST REGION.

THEREFORE, IN CONSIDERATION OF THE TERMS AND CONDITIONS SET FORTH HEREIN THE INDOT, IDNR, IDEM AND USFWS AGREE AS FOLLOWS:

1. INDOT IN COOPERATION WITH THE IDNR, IDEM AND USFWS SHALL DETERMINE THE LOCATION OF SINKHOLES, CAVES, UNDERGROUND STREAMS, AND OTHER RELATED KARST FEATURES AND THEIR RELATIONSHIP PRIOR TO PROPOSED ALTERATIONS OR CONSTRUCTION IN KARST REGIONS OF THE STATE. A CONSULTANT WITH EXPERTISE IN KARST GEOLOGY/HYDROLOGY MAY ASSIST IN THE IDENTIFICATION AND CHARACTERIZATION OF THE KARST FEATURES. THE CHOICE OF THE CONSULTANT RETAINED BY INDOT WILL BE SUBJECT TO THE REVIEW OF IDNR, USFWS AND IDEM.

2. TASKS TO ACCOMPLISH THIS WORK WILL INCLUDE:

RESEARCH AVAILABLE FROM PUBLIC AND PRIVATE SOURCES FOR INFORMATION RELATIVE TO KARST FEATURES.

FIELD CHECK KARST AND CAVE FEATURES THAT APPEAR FROM THE FIRST TASK AND IDENTIFY ANY ADDITIONAL KARST FEATURES.

PREPARE A DRAFT REPORT, WITH PHOTOGRAPHS AND MAPS, DRAINAGE AREAS, AND LAND USE OF THAT DRAINAGE AREA FOR EACH SINKHOLE OR KARST FEATURE. DYETRACING AND/OR OTHER GEOTECHNICAL INFORMATION TO DETERMINE SUBSURFACE FLOW OF WATER IN THE PROJECT AREA AND SURFACE WATER DRAINAGE PATTERNS OF THE AREA. CALCULATIONS OF ESTIMATES OF ANNUAL POLLUTANT LOADS FROM THE HIGHWAY AND DRAINAGE WITHIN THE RIGHT-OF-WAY WILL BE MADE, INCLUDING PRIOR TO, DURING AND POST CONSTRUCTION ESTIMATES. THE DESIGN OF THE TREATMENT OF THE KARST FEATURES WILL TAKE INTO CONSIDERATION TREATMENTS NECESSARY TO MEET THE STANDARDS OF THE MONITORING AND MAINTENANCE PLAN.

THAT REPORT WILL BE USED AS A TOOL TO ASSIST IN DETERMINING THE PROPOSED HIGHWAY ALIGNMENT. THE INTENT OF INDOT IS TO AVOID KARST AREAS AND USE ALTERNATE DRAINAGE WHERE POSSIBLE. 
3. IDNR, IDEM AND USFWS WILL BE REQUESTED TO REVIEW AND COMMENT ON THE FINDINGS AT THE EARLY COORDINATION PHASE OF PROJECT DEVELOPMENT.

4. INDOT, USING THE INPUT FROM IDNR, IDEM, AND USFWS WILL BEGIN TO FORMULATE APPROPRIATE MEASURES TO OFFSET UNAVOIDABLE IMPACTS TO THE KARST FEATURES. IT IS UNDERSTOOD BY ALL PARTIES THAT SOME OF THE METHODS PROPOSED AT THIS TIME WILL BE GENERIC AND COULD BE APPLIED THROUGHOUT THE LENGTH OF THE CORRIDOR. OTHER METHODS MAY BE SPECIFIC TO A PARTICULAR CAVE OR KARST FEATURE. SOME OF THE APPROACHES MAY REQUIRE ADDITIONAL INVESTIGATIONS TO DETERMINE THEIR NECESSITY AND/OR THEIR FEASIBILITY. A REVISED DRAFT REPORT WILL BE PREPARED BY INDOT'S CONSULTANT AND PROVIDED TO THE IDNR, IDEM, AND THE USFWS AS PART OF THE DESIGN REVIEW PROCESS.

5. DRAINAGE ENTERING FROM BEYOND THE RIGHT-OF-WAY WILL BE TREATED ACCORDING TO THE SAME PROCESS AS DRAINAGE GENERATED BY THE PROJECT.

6. AS THE PROJECT PROGRESSES FURTHER INTO THE DESIGN PHASE, THE IDNR, IDEM AND USFWS WILL BE INVITED AND WILL ATTEND FIELD CHECKS AND MEETINGS DEALING WITH EFFORTS TO NEGATE OR MINIMIZE ADVERSE IMPACTS.

7. HAZARDOUS MATERIALS TRAPS (HMT'S) WILL BE CONSTRUCTED AT STORMWATER OUTFALLS AND OTHER LOCATIONS THAT WILL PROTECT KARST FEATURES FROM SPILL CONTAMINATION.

8. INDOT AGREES TO DEVELOP A MONITORING AND MAINTENANCE PLAN FOR THE AFFECTED KARST FEATURES. IDNR, IDEM AND USFWS WILL BE PROVIDED AN OPPORTUNITY TO REVIEW THIS PLAN. THE ESTABLISHMENT OF WATER QUALITY AND A POINT AT WHICH A STANDARD IS ESTABLISHED FOR REMEDIATION WILL BE A PART OF EACH MONITORING PLAN. THE RESULTS OF THE MONITORING WILL BE SUBMITTED TO IDNR, USFWS, AND IDEM ON A REGULAR BASIS.

9. A LOW SALT, AND NO SPRAY STRATEGY WILL BE DEVELOPED FOR EACH FUTURE PROJECT. A SIGNING STRATEGY FOR THESE ITEMS WILL ALSO BE DEVELOPED FOR EACH PROJECT.

10. PRIOR TO ACCEPTANCE OF THE FINAL DESIGN PLANS AN AGREEMENT WILL BE DEVELOPED WHICH WILL SET OUT THE APPROPRIATE AND PRACTICABLE MEASURES TO OFFSET UNAVOIDABLE IMPACTS TO KARST FEATURES. THIS AGREEMENT WILL BE SIGNED BY THE DEPARTMENT DIRECTOR OF IDNR. THE COMMISSIONER OF THE IDEM, THE COMMISSIONER OF INDOT AND THE SUPERVISOR OF THE USFWS BLOOMINGTON, INDIANA FIELD OFFICE. THE AGREEMENT WILL BECOME A PART OF THE CONTRACT DOCUMENTS FOR THE PROJECT, WILL BE DISCUSSED AT THE PRE-CONSTRUCTION CONFERENCE AND WILL BE ON FILE AT THE OFFICE OF THE PROJECT ADMINISTRATOR.

11. INDOT WILL ASSURE THAT THE TERMS OF THE AGREEMENT WILL BE COMPLETED WITH ALL SAFEGUARDS GIVEN TO THE KARST AREA. SPECIAL PROVISIONS, WHICH ARE BINDING PROVISIONS THAT ARE A PART OF THE CONTRACT, WILL BE INCLUDED OUTLINING THE PRECAUTIONS TO BE TAKEN. CONSTRUCTION AND DESIGN STRATEGIES FOR HANDLING KARST FEATURE WILL BE DISCUSSED WITH THE CONTRACTOR(S) AND PROJECT ADMINISTRATOR DURING THE PRE-CONSTRUCTION CONFERENCE. PROJECT ADMINISTRATOR SHALL ENSURE THAT THE CONTRACTOR IS FOLLOWING THE NEW EROSION CONTROL STANDARDS THAT MEET RULE 5 OF 327 IAC 15 AND ANY SPECIAL PRECAUTIONS OUTLINED IN THE DESIGN PLANS THAT THE SINKHOLE TREATMENT IS BEING HANDLED CORRECTLY. THE EROSION CONTROL PLAN MUST BE AVAILABLE AT THE PROJECT ADMINISTRATOR'S OFFICE. AN EMERGENCY RESPONSE PLAN WILL BE MADE A PART OF THE 
CONTRACT DOCUMENTS. IN ADDITION, THE CONTRACT DOCUMENTS WILL CONTAIN A STRATEGY FOR SIGNING TO ALERT THE PUBLIC TO THE FACT THAT ALL TYPES OF SPILLS ARE POTENTIALLY HAZARDOUS TO THE KARST ENVIRONMENT. FOR INDOT, THIS PLAN WOULD BE PROCEDURE 20 OF THE FIELD OPERATIONS MANUAL DATED 6/24/92 (ATTACHED).

12. THE LOCATION AND NATURE OF THE SINKHOLES AND DRAINAGE SCHEMATIC WILL BE PROVIDED TO THE IDEM. THEY WILL PROVIDE THE INFORMATION TO THE APPROPRIATE LOCAL AUTHORITIES AND THE HAZMAT TEAMS. AN EMERGENCY RESPONSE PLAN WILL BE FOLLOWED. THIS CONSTITUTES PROCEDURE 20. INCLUDED IN THIS INFORMATION IS AN UNDERSTANDING THAT ALL TYPES OF SPILLS ARE POTENTIALLY HAZARDOUS TO KARST REGIONS.

13. IDNR, IDEM AND USFWS PERSONNEL WILL MONITOR CONSTRUCTION AND MAINTENANCE TO THE AGREED UPON TERMS, AS DEEMED NECESSARY.

14. IF DURING CONSTRUCTION IT IS FOUND THAT THE MITIGATION AGREEMENT MUST BE ALTERED, ALL OF THE AGENCIES WILL BE CONTACTED AND AGREEMENT REACHED PRIOR TO WORK CONTINUING IN THAT SPECIFIC AREA OF THE PROJECT. IN ORDER TO NOT UNDULY DELAY PROJECTS, A TWO WORKING DAYS RESPONSE TIME IS NEEDED FROM THE RESOURCE AGENCIES.

15. TREATMENTS WILL BE MAINTAINED DURING CONSTRUCTION BY MEANS OF A VISUAL INSPECTION ON A WEEKLY BASIS OR AFTER EVERY RAIN. CORRECTIVE ACTION WILL $B E$ TAKEN AS NEEDED.

16. IF AFTER THE ABOVE PROCEDURE IS FOLLOWED AND A STATE/FEDERAL ENDANGERED/THREATENED SPECIES IS FOUND DURING CONSTRUCTION, WORK IN THAT AREA OF THE PROJECT WILL STOP. THE IDNR, AND USFWS WILL BE IMMEDIATELY NOTIFIED. THE IDNR AND USFWS WILL PROMPTLY INVESTIGATE THE SITUATION, ADVISE THE PROJECT ADMINISTRATOR AND ASSUME RESPONSIBILITY FOR PROTECTING THE ENDANGERED SPECIES AND TAKING THE APPROPRIATE ACTION.

17. THIS DOCUMENT WILL BE REVIEWED ANNUALLY OR MORE FREQUENTLY AT THE REQUEST OF ANY OF THE FOREGOING AGENCIES.

(SIGNED)

MR. FREDERICK C. P'POOL, COMMISSIONER

Indiana Department of Transportation

(SIGNED)

MR. PATRICK R. RALSTON, DIRECTOR

INDIANA DEPARTMENT OF NATURAL RESOURCES

(SIGNED)

MS. KATHY PROSSER, COMMISSIONER

INDIANA DEPARTMENT OF ENVIRONMENTAL MANAGEMENT

(SIGNED)

MR. DAVID C. HUDAK, FIELD SUPERVISOR, BLOOMINGTON FIELD OFFICE

U.S. FISH AND WILDLIFE SERVICE 